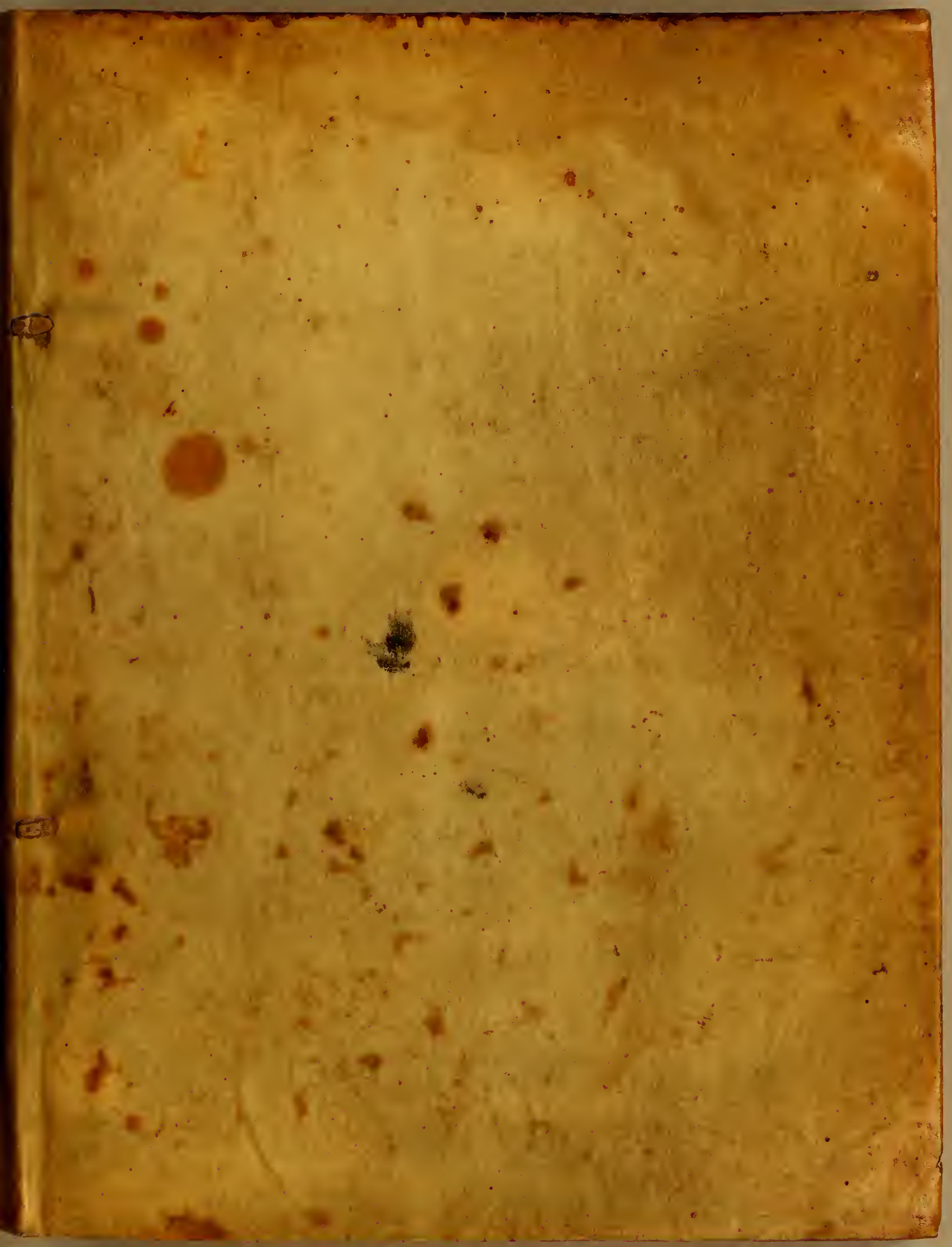




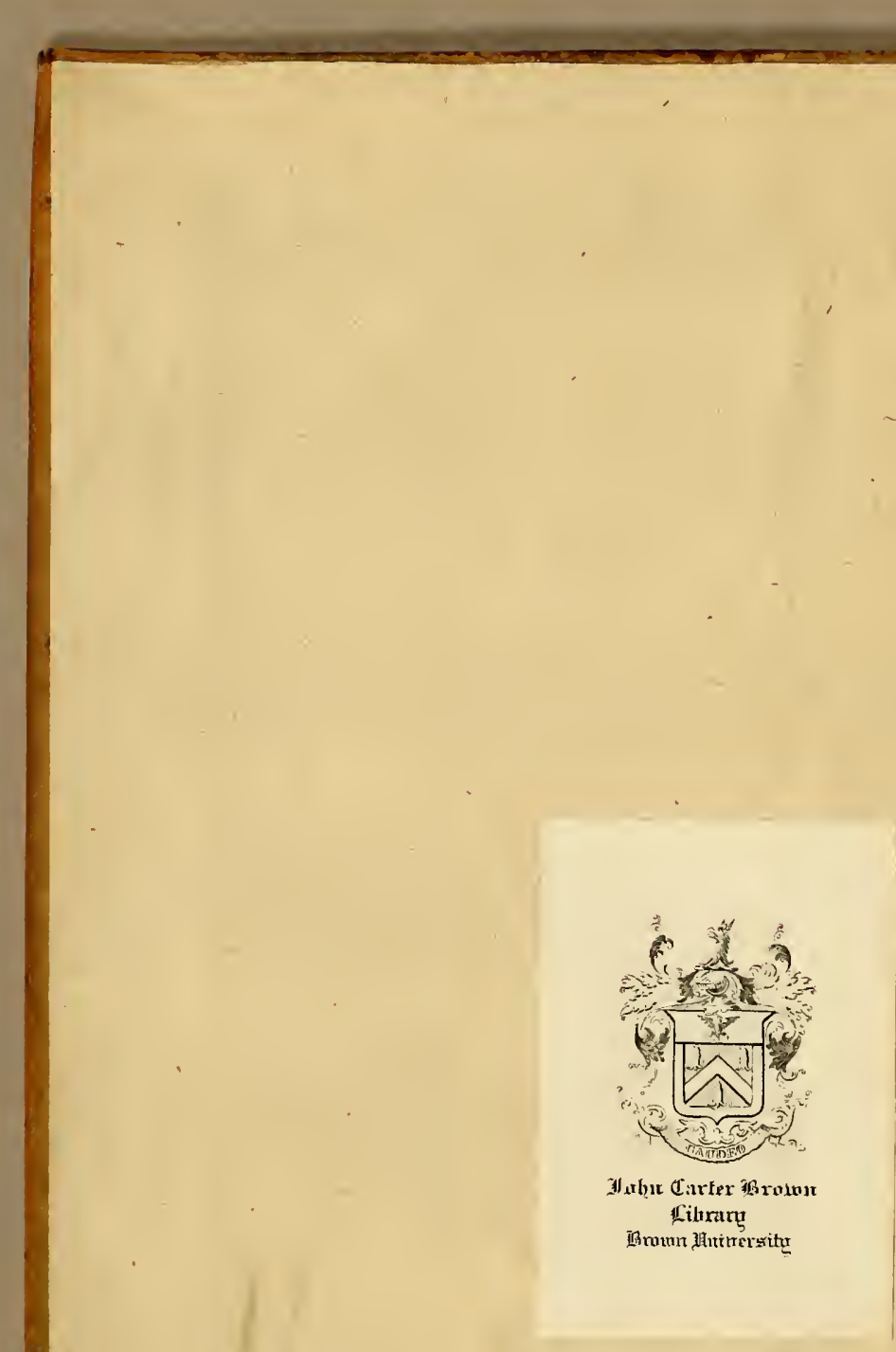




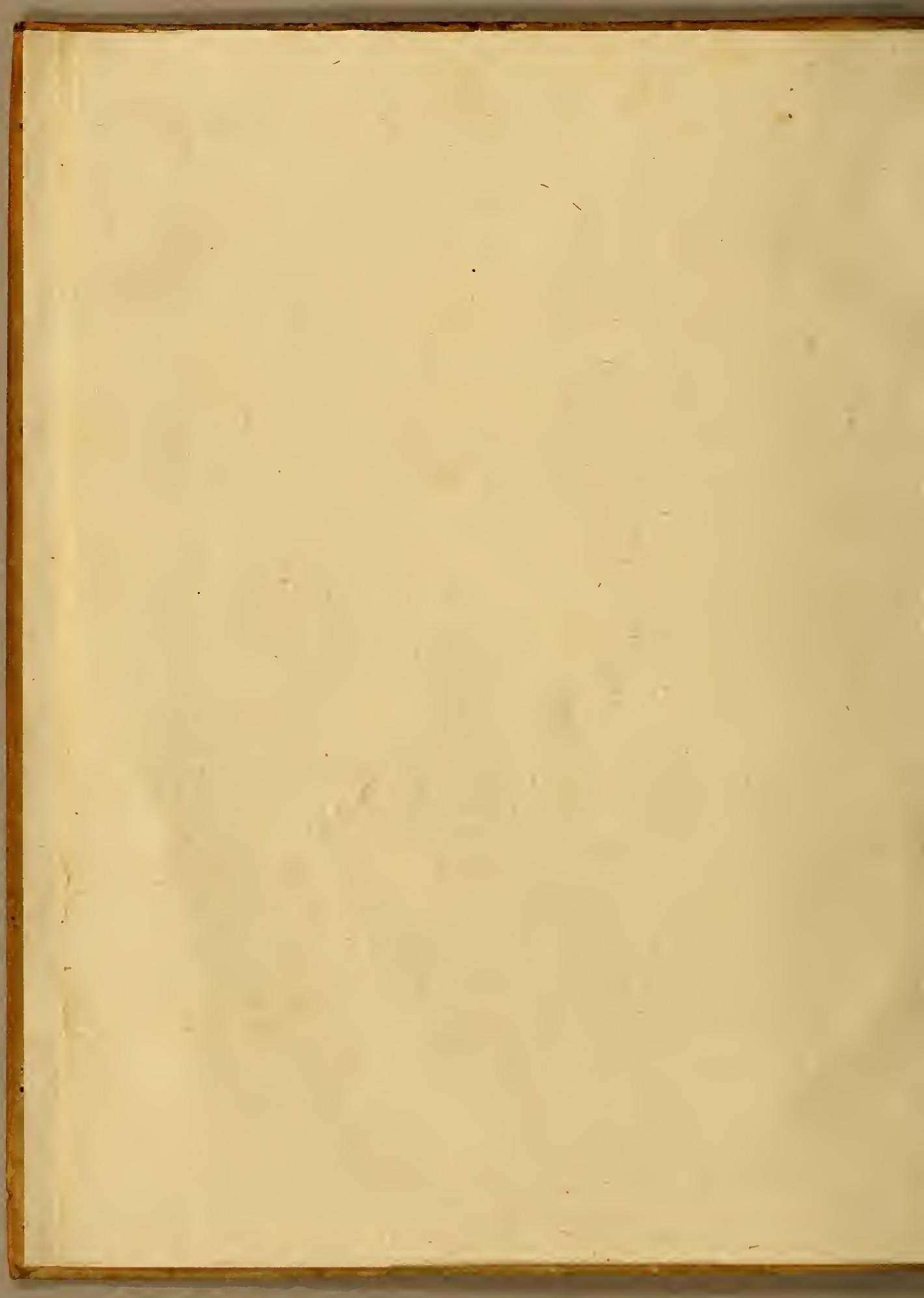


ifrg divenitio rarip as cagiones he if res neffi gli Evemplar, che ju' popatile, ber fimove didar qusto a.i Stranieni dell opulenia del Brasile.

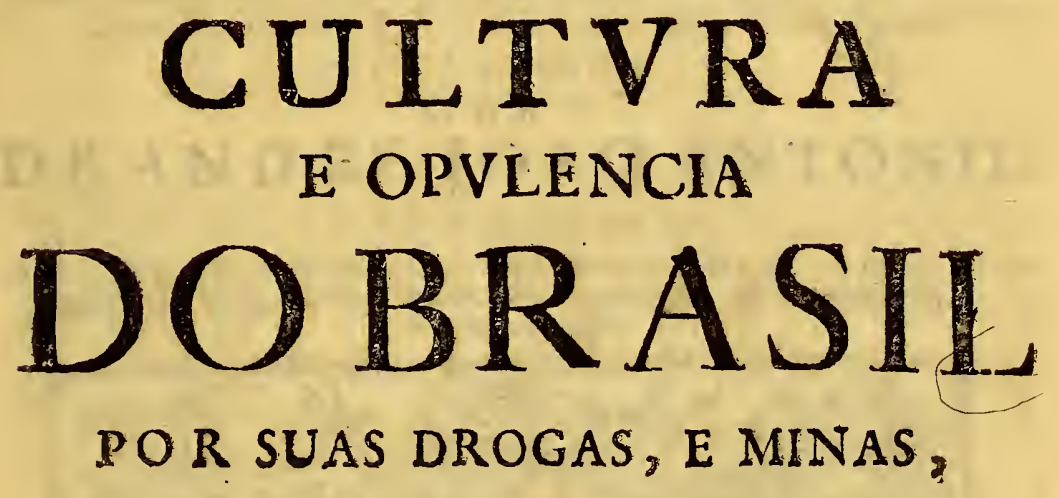




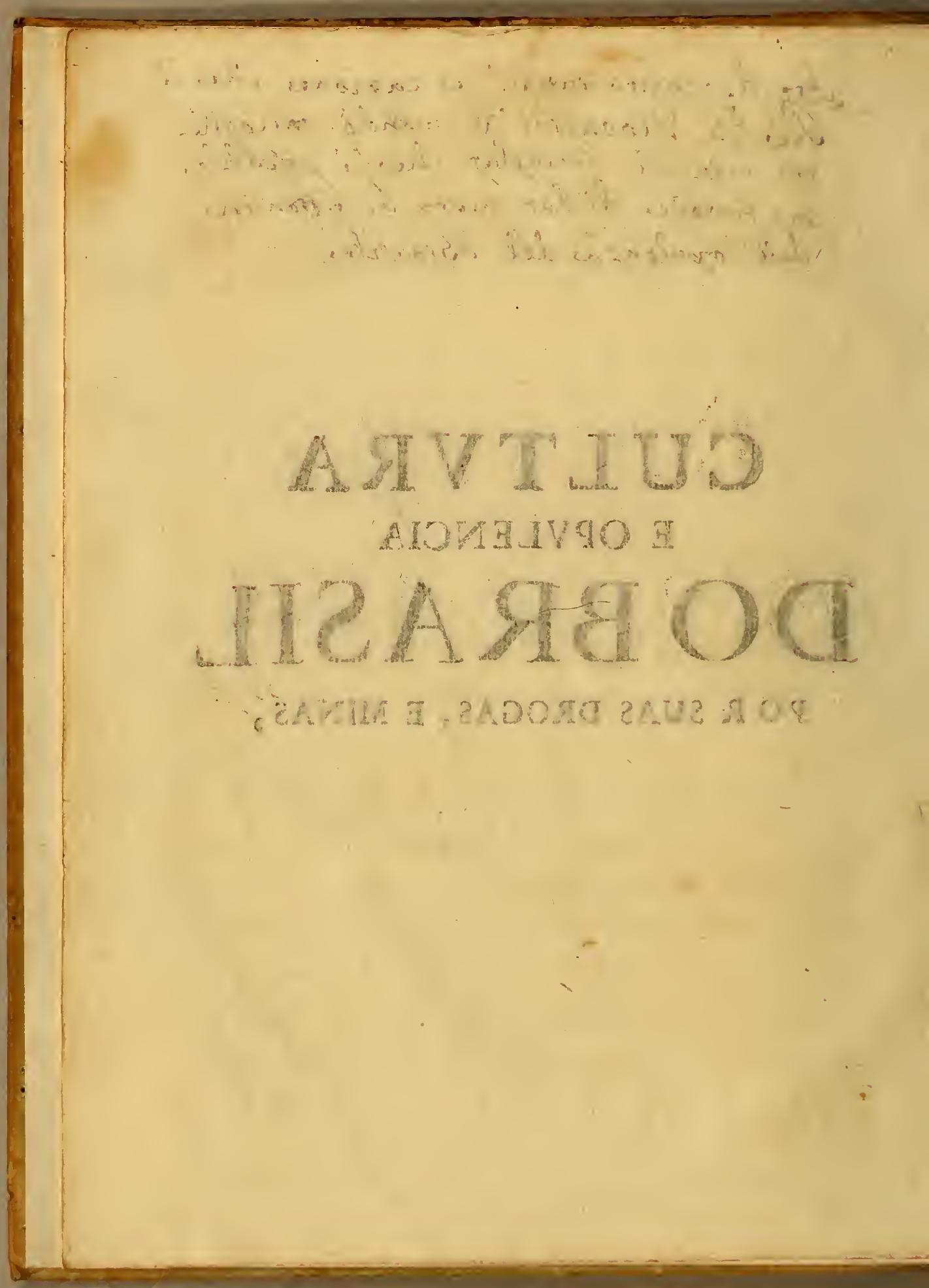




\section{CULTURA, E OPULENCIA}
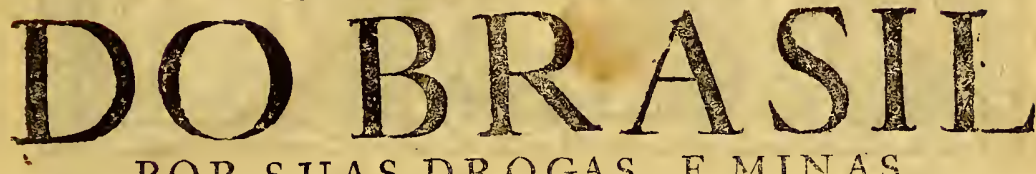

PORSUAS DROGAS, E MINAS,

Com varias neticias curiofas do modo de fazer o Afucar ; plantar,

\& beneficiar o 'Tabaco ; tirar Ouro das Minas ; \& defcubrir as da Prata;

$E$ dos grandes emolumenios, que efta Conquifta da America Meridional dá ao Reyno de PORT U $A L$ com clies, ó ontros generos, $\mathcal{C}$ Contratos Reacs.

$\mathrm{OBR} \mathrm{A}^{-}$

\section{DE ANDRE JOAO ANTONIL}

O FFERECID A

Aos que defejaó ver glorificado nos Altares ao Veneravel Padre JOSERH DE ANCHIETA Sacerdote da Companhia de J ES U, Miflicuario A poftolico, \& novo Thaumaturgo io Rrafil.

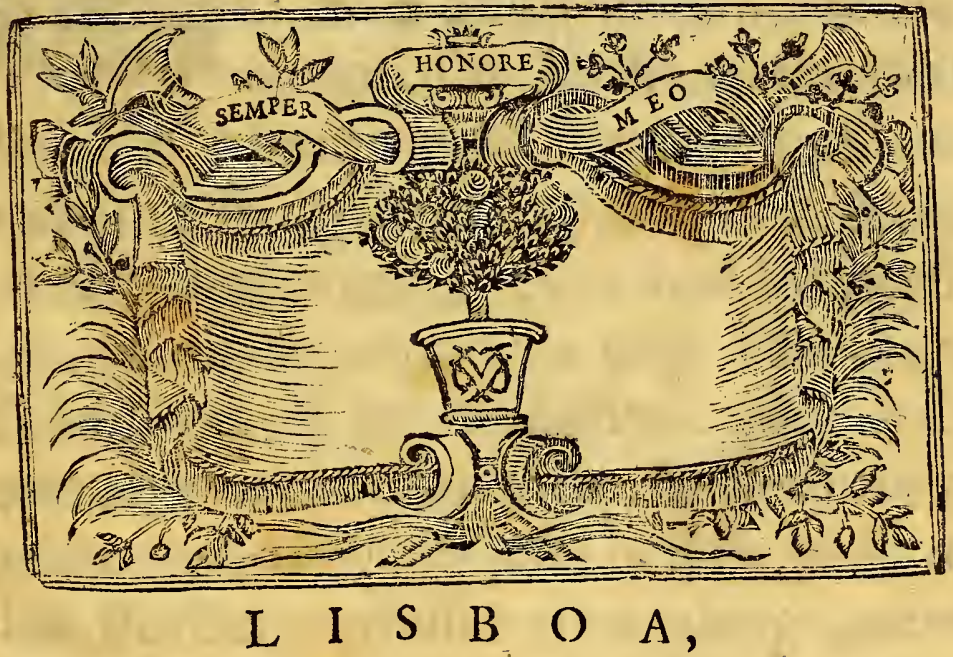

Na Officina Ral D E S L A N D E S I A N A: Com as licenças neceffarias Anno de $17 \mathrm{I}$. 


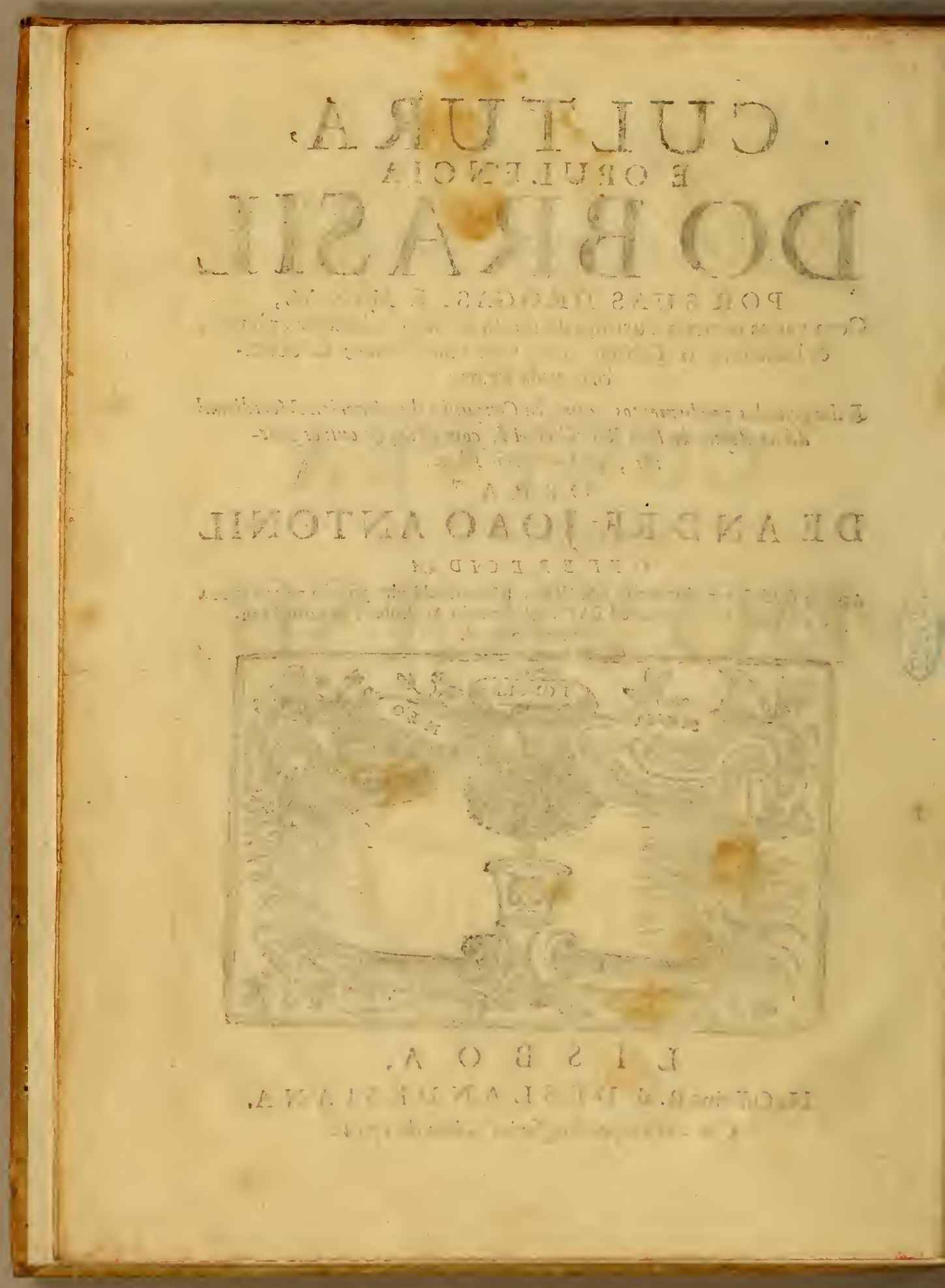




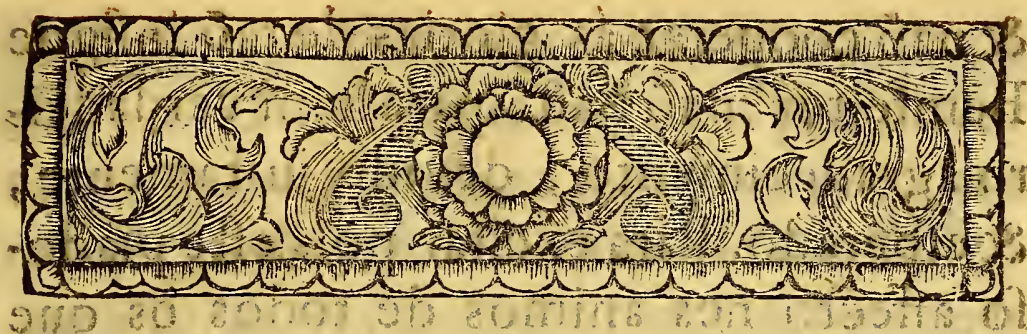

CAOSENCHORES DEENCGE

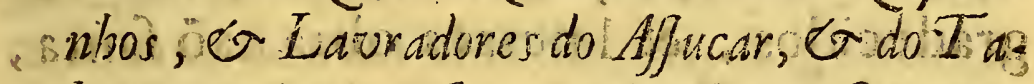
- baco, Go hos quéfe occupaj em tirar Ourodas

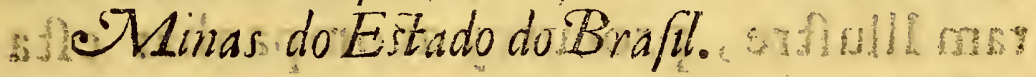
EVE tanto o Brafil ao Véne- 46 ravel Padre Jofeph de Anchieta, hum dos primeiros, \&r mais fervorofos Miffionarios denta America Meridional; que a boca chea o chama feu grande Apoftolo \& $\&$ ovo Thaumaturgo, pela luz Euangeli; ca, que communicou a tantos milliares deIndios, 8 pelos innumeraveis milagres, que obrou em vida, \& obra continuamenteinvocado para beneficio de to dos. Porèn confeffar entas obrigaçoens, -ingut

$$
*_{3}
$$

\& naõ 
\& naó cooperar ás glorias de taô infigne Bemfeitor, náo bafta para hum verdadeiro agradecimento, devido juftamente, \& efperado. Para excitar pois efte piadofo affecto nos animos de todos os que mais facilmente podem ajudar como as gradecidos, \& liberaes obrà tà fanta, como he a Canonizaçaó de hum Varaó tam llluftre, procurey acompanhar efta jufta petiçaó com alguma dadiva, que pudeffe agradár, \& fer de algũa utilidade aos que nos Engenhos do Affucar, nos Partidos, \& nas Lavouras do Tabaco, \& nds Minas do Ouroexperimentaō o favor do Ceo com notavel aumento dos. bens temporaes. Portanto com eftalimitada offerta provoco aquella generofa $\mathrm{l}$ beralidade; que naõ confente fer rogada? por naõ parecer qque dando quer venden beneficios. $\mathbf{E}$ ao melmo Veneravel $\mathbf{P a -}$ dre Jofeph de Anchieta peçoencarecida. mente, que queira alcançar de Deos cen-

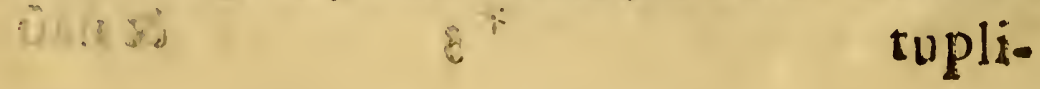


tuplicada remuneraçao na Terra, \& no Ceo, a quem le determinar a promover com alguma efmola as fuas honras $;$ para que publicadas nos Templos, \&celebradas nos Altares, acrecentem tambemma yor gloria áquelle Senhor, que he honrado nas honras dos Santos, \& glorifica do ém luas glorias.

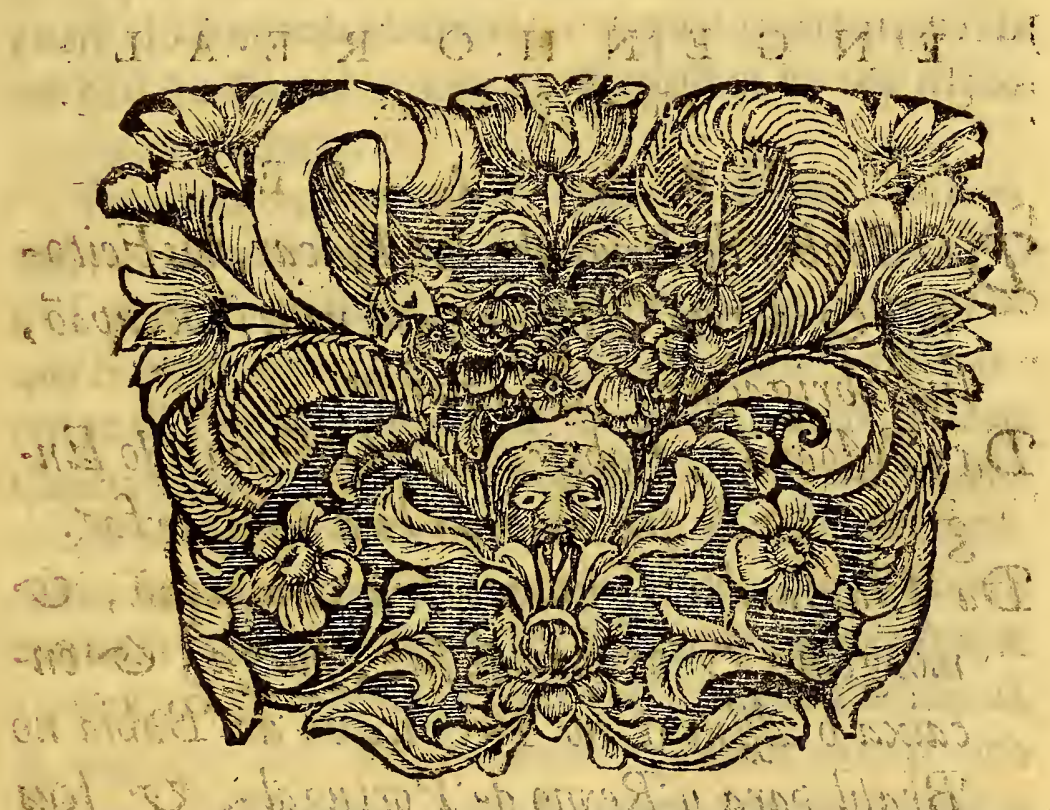

.19098

$*_{4}$

PR I: 


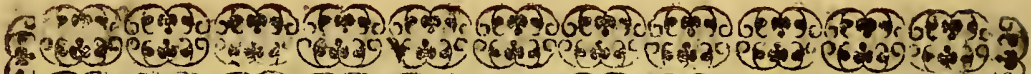
(4) a

PRLMELRA PARTE.

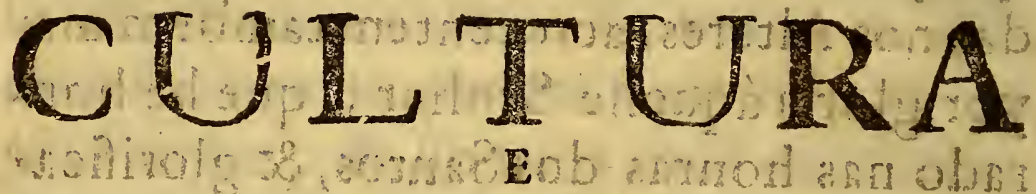

OPVLENCIA DOB R SIL $\mathrm{Na}$ Lavra do Affucar.

E $N G$ G E N H Moente, \& coirente.

\section{T R A T A - S E}

DO Senbor do Engenbo do Aj]ucar, dos Feito. res, so outros Officiaes, que nelle fe oceupio, Iuns obrigacoens, e Jalarios.

Da 2 Koenda, Fabrica, E Offimas do Engenbo, of do que em cada büa dellas fe far.

Da Planta das Camias, Iua conduç̧á, es moagem - of de comolefat, purga, \& encaixa-o Afjucar no Reconcavo da Babia no Brafil para o Reyno de Portugal, \& Jeus emolumentos. 


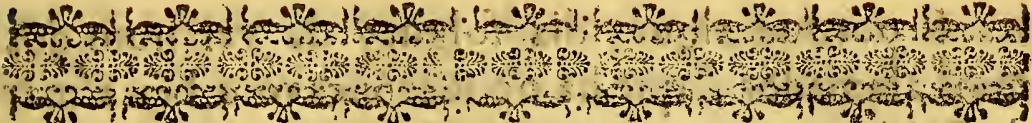

\section{P
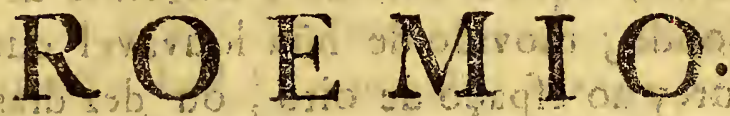

M U E chamouàs Officinas, em quele N 1 - fabrica A Alucar, Engenhos, acerrou 2. Nerdaderamente no nome.Porq́ quem Q 2 quená as vé, \& confidera com a refe. xaó, q́ merecen; he obrigado a confels far, que laó buns dos principaes partos, \& invençoens do Engenho humano, o qual como pequena porçaó do Divino, lempre fe moftra no leu modo deobrar, admiravel.

Dos Engenhos huns re chamaö Reaes, outros inferiores vulgarmente Eugenhocas. Os Rears ga: nhâraọefte apellido, por terem rodas as partes, de que fe compoem, $\&$ rodas as Officinas perfeizas, cheas de grande numero de Efcravos, com miros

- Cannaveaes proprios, 3 outros obrigadosá Moen. $\mathrm{da}:$ \& principalmente porterem a Realeza de moe. rem com agua, á differen ça de ourros, que moem com Cavallos, \& Buys, \& lá menos provî́dos, \& apareihados; ou pelo menos com menor perferça \& largueza, das officinas neceffarias, \& com pouco numero de Elcravos, para fazerem, como dizem, o Engenho Moente , \& Corrente.

E por: 
E porque algum dia folguey de ver hum dos mais afamados, que ha no Reconcavo á beira-mar da Bahia, a quem chamaó o Engenho de Serigippe do Conde; movido de húa louvavel curiofidade; procurey no efpaço de oito, ou dez dias, que ahi eftive, tomar noticia de tudo o que o fazia taóce. lebrado, \& quafi Rey dos Engenhos Reaes. Evalen. domedas informaçoens, que me deo, quem o adminitrou mais de trinta annos com conbecids in. telligencia, \& com acrecentamento igual à induftria: \& da experiencia de hum famolo Melte de Allucar, que cincoenta annos fe occupou neffe of ficio com venturofo fuccelto, 2 dos mais Officiaes de nome, as quaes miudamente perguntei o q́a cắ da qual pertericia me relolvia deizar nefte borráó tudo aquillo, que na limitaçaó do tempo fobredito apreffadamente, mas comatrençañ ajuntey, \&c eftendicom o mefmo eftylo, \& modo de fallar claro, \& chaó, que fe ufa nos Engenhos: para que os que rao laberr o que cafta a doçura do Affucar a quem olavra, o conheçaō, \&e fintaö menos dạ. por elle preço, que val: \& quem de novo entrar na adminititraçẫ de algú Engeriho, tenha eftas no= ricias prapticas, dirigidas a obrar com acerto; que he o que en toda a occupaçaó le deve defejar, \& intentar. E para mayor clareza, \& ordem, reparti em varios Capiculos undo o que pertence a cíta Dro$\mathrm{ga}^{2}$. 
ga, \& a quem por ella, \& nella trabalha ; comes çando, depois de relatar as obrigaçoens de cada qual, defde a primeira origem do Afucar na Can. na, ate fua cabal perfeiçáo nas Caixas, conforme - meu limirado cabedal; que pelo menos fersirá, para dar a outros de melhor capacidade, \& perna mais ligeira, \& bem aparada, algum eftimulu de aperfeiçoar efte embriào. E (e alguém quizer faber - Author defte curtor, \& util trabatho; elle he hum amigo do bem publico chamado.

\section{OAlonyino Torcanio.}

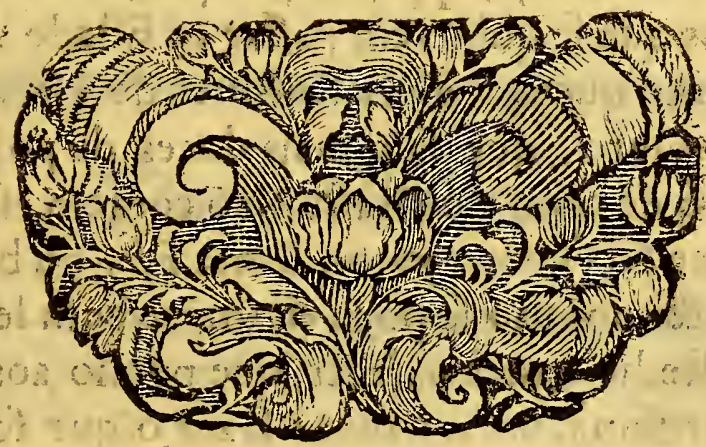




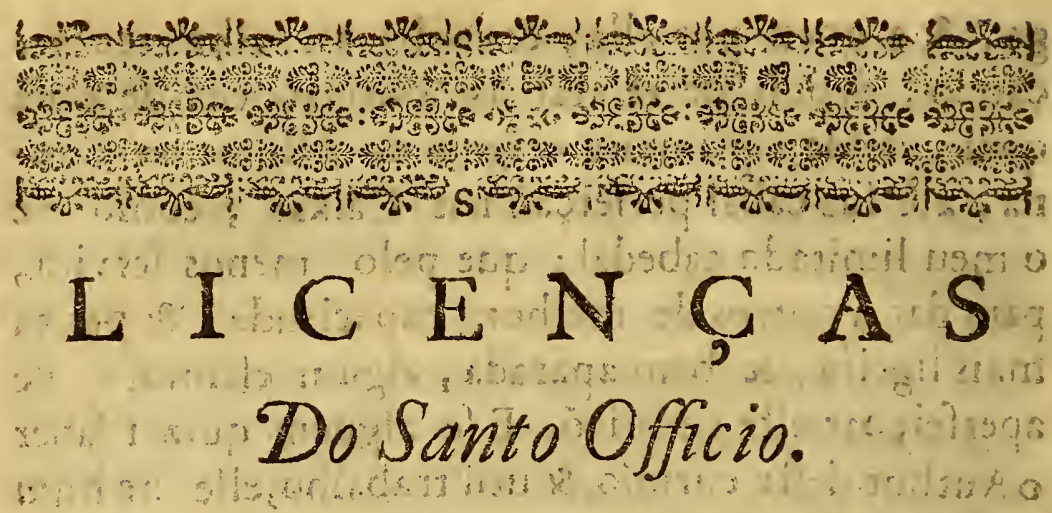

I L LUSTRISSIMO SENHOR...

12. Evi efte livro intitulado Cultura, $\delta \sigma^{\circ} O$ pu= 1. lencia do Brafil, mencionado na petiçaō acima, \& Cendo a obra de engenho,pela boa difpofiçač, com que o leu Author o compoz, he muito me. recedora da licença, q́ pede : porque por efte meyo laberáó os que fe quizerem paffar ao Eftado do Bra. fil, o muiro que cuftao as Culcuras do Affucar, Tabaco, \& Ouro, que fao mais doces de polsuir no Reyno, de deavar no Brafil. Nao contem elte livro colía, que leja contra nolsa Santa Fé, ou bons co. fumes, \& por ifso fe póde eltampar com letras de Ouro. ERe he o meuparecer, que pontio aos pès de $V$. Illutrifrma, para mandar tazer o que for fervido. Santa Anna de Lisboa em oito de Novembrode $x>10$.

Fr. Paulo de Saü Boaventura. $\therefore \quad \cdots$ 
T Aó contem efte Tratado coufa fúfpeitola contra nofsa Santa Fè, \& pureza dos bons coftumes, \& affimfendo V.Illuftriffima fervido pó= de conceder a licença, que pede o Author. Trin= dade em zo.de Novembro de 1710 .

Fr. Manoel da Conceygăo.

TIftas as informaçoens, póde-le imprimir oli2. vro incitulado, Cultura, , Go Opulencia do Brafil, \& impreflo tornarà para le conferir, \& dar licença que corra, \& lem ella naō correrá. Lisboa 5: de Dezembro de 1710.

Moniz Haffe Monteiro. Ribeiro.

Fr. Encarnaçaõ. Rocba. Barreto.

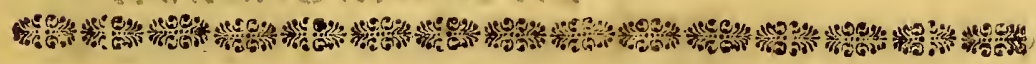

\section{Do Ordinario.}

D Ode-fe imprimir o livro intitulado, Cultura, Go Opulencia do Brafil, \& impreflo torne parafe conferir, "\& dar licença que corra, \& fem ella naó correrá. Lisboa i 2 . de Dezembrö de 1710.

$$
\text { B. di'Tagafte: }
$$




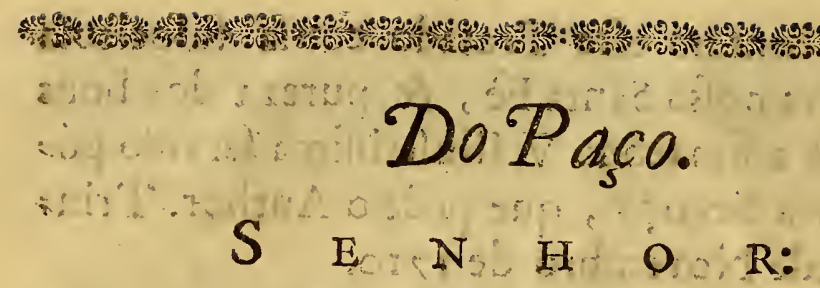

T I livro, que V.MAGESTADE foy fervido - remeterme: feu Author Andrè Joá Antonil ; \& fobre nao achar nelle coufa que encontre o Real ferviço de V. Mageftade, me parece ferà mui= to util para o Cómercio : porque defpertará as dili= gencias, \& incitará a que le procurem taôfaceis in. zerefles. Julga.o muito dignoda licença que pede, V. Mageftade ordenará o que for fervido. Saõ Do. mingos de Lisboa 1 5. de Janeyro I7II.

\section{Fr. Manoel Guilberme.} -

Ue fe poffa imprimir,viftas as licenças do Sãto Officio, \& Ordinario, \& depois de impreffo tornaráa Mefa para fe conferir, \& taxar, \& fem iffonaó correrá. Lisboa 17.de Janeyro de I7II.

Oliveira. Lacerda. Cameiro.

Botelbo. Cogla. 
Oncorda com o leu original. Convento da Santiffima Trindade de Lisboa 5. de Março. de I III.

\section{Fr. Manoel da Conceycäo.}

IIto eftar conforme com leu original, póde correr. Lisboa s.de Março de I7rI.

Moniz. Haffe. Monteyro. Ribeyro. Rocha. Fr. Encarnaçă̈. Barreto.

D Ode correr. Lisboa 6. de Março de I7II.

$$
\text { M. Bifpo de Tagafe. }
$$

T Axaõ efte livro em dous toftões. Lisboa 6. de Março de I7Ir.

Duque P. Oliveyra. Botelho. Pereyra. 


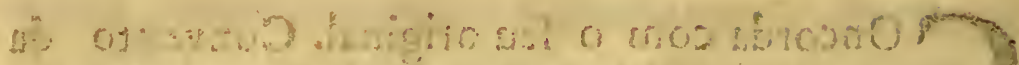

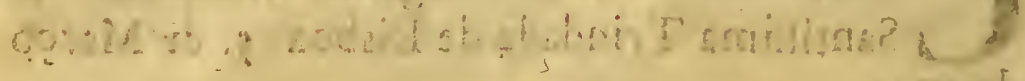

$$
\text { As }
$$

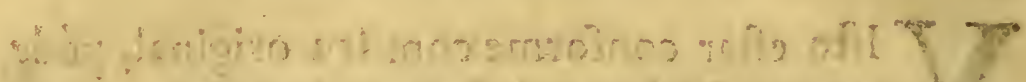
itis of

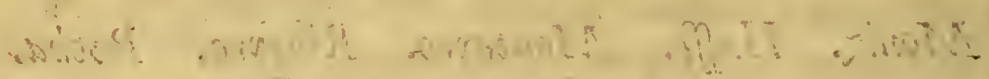

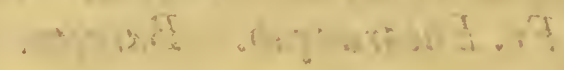

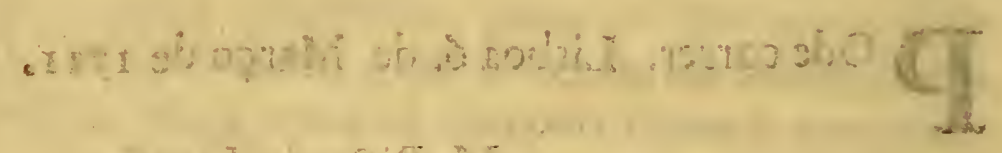

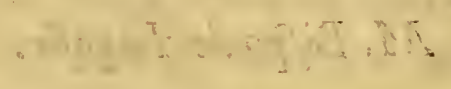

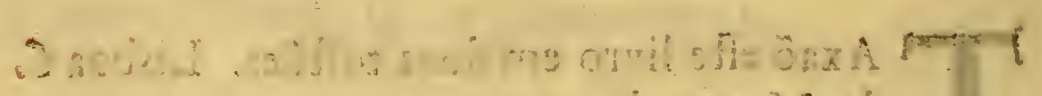

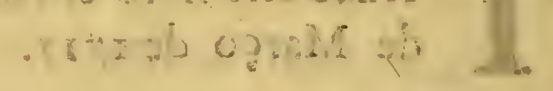

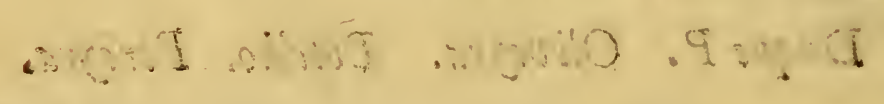


Fol.t
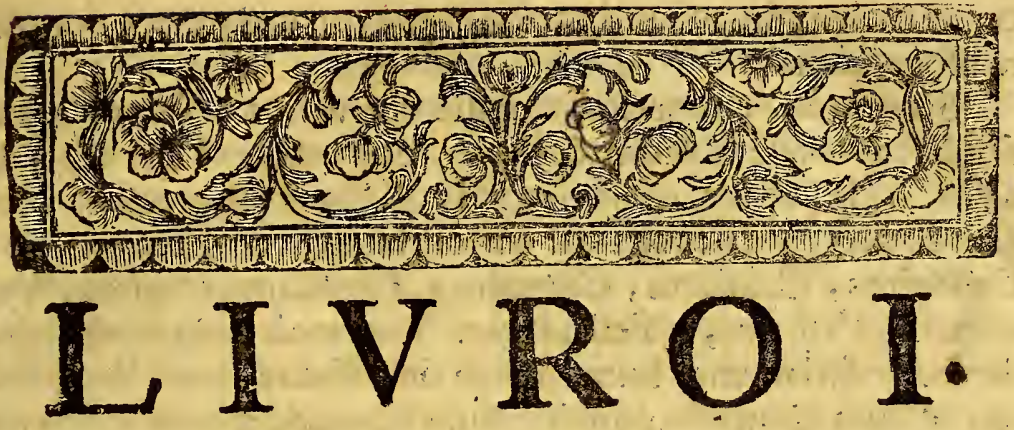

\section{A P I T V L O I.}

Do cabedal, que ba de ter o Senbor de bum Engenbo Real.

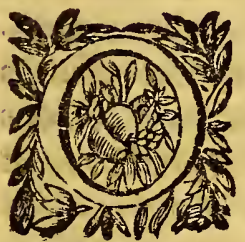

SER Senhor de Engenho, he titulo, a què muiros afpiraó; porque traz configo o fer fer vido, obedecido, \& refpeitado de muitos. E fe for, qual deve fer, homem de cabedal, \& governo; bem fe póde eftimar no Brafil o fer Se: nhor de Engenho,quanto proporcionadamente fe eftimaó os Titulos entre os.Fidalgos do Reyno. Porque Engenhos ha na Bahia, que daó ao Senhor quatro mil pães de Affucar, \& outros pouco menos, com canna ebrigada à Mo: enda, de cujo rendimento logra o Engenho ao menos a ametade, como de qualquer outra, quenelle livremente fe moe: \& em algumas partes, ainda mais que a ametade.

Dos Senhores dependem os Lavradores, quetem Partidos arrendados em terras do mefmo Engenho, como os Cidadaós dos Fidalgos : \& quanto os Senhores faó mais poffantes, \& bem aparelhados de todo o neceffario, affaveis, \& verdadeyros ; tanto mais faó procurados, ainda dos que naó tem a A

canna 


\section{2 \\ Cultura,}

canna cativa, ou por antiga obrigaçaó, ou por preço, que para iffo recebèraó.

Servem aoSenhor do Engenho em varios officios, alèm dos Efcravos de enxada, \& fouce, que tem nas Fazendas, \& na Moenda; \& fóra os Mulatos, \& Mulatas, Negros, \& Negras de cafa, ou occupados em outras partes; Barqueiros, Canoeiros, Calafates, Ca rapinas, Carreiros, Oleiros, Vaqueiros, Paftores, \& Pefcadores. Tem mais cada Senhor deftes neceffariamente hum Meftre de Affucar, hum Banqueiro, \& him Contrabanqueiro, hum Purgador, hum Caixeiro no Engenho, \& outro na Cidade, Feitores nos Partidos, \& Roças, hum Feitor Mór do Engenho : \& para oEfpiritual, hum Saceidote feu Capellaô : \& cadaqual deftes Officiaes tem foldadia.

Toda a Efcravaria (que nos mayores Engenhos pafa o numero de cento \& cincoenta, \& duzentas Peças, contando as dos Partidos) quer mantimentos, \& farda, medicamentos, enfermaria, \& Enfermeiro: \&r para iffo faó necelfarias Roças de muitas mil covas de Mandioca. Querem os Barcos. velame, cabos, cordas; \& breu: Querem as Fornalhas, que por fete, \& oito mezes ardem de dia, \& de noite, muita lenha: \& paraiffo ba mifter dous Barcos velejados, para fe bufcar nos. Portos, indo.hum atraz do outrofem parar, \& muito dinheiro para a comprar : ou grandes mattos, com muitos carros, \& muitas juntas de Boys, para fe trazer. Queren os Cannaveaes tambem fuas barcas, \& carros com dobradas efquipaçoens de Boys : querem enxadas, \& 8 fouces: Querem as Serrarias machados, \& ferras: Quer a Moenda de toda a ca. fta de Paos de ley de fobrecellente, \& muitos quintaes de aço, $\&$ de ferro. Quera Carpétaria madeiras felectas, \& fortes para Efteyos, Vigas, Afpas, \& Rodas: \& pelo menos os inftrumentos mais ufuaes, a faber Serras, Trados, Verrumas, Compaffos, Regras, Efcopros, Enxós, Goivas, Machados, Martellos, Cantins 


\section{\& Opulencias do Brafl.}

tins, \& Junteiras, pregos, \& Plainas. Quera Fabrica do Affucar Paroes, \& Caldeiras, Tachas, \& Bacias, \& outros muitos inftrumentos menores, todos de cobre; cujo preço paffa de oito mil cruzados, ainda quando fe vende naó tam, caro, como nos annos prefentes. Saó finalmente neceffarias, alèm das fanzallas dos Efcravos, \& alèm das moradas do Capellaô, Feitores, Meftre, Purgador, Banqueiro, \& Caixeiro, húa Capella decente com feus ornamentos, \& todo o aparelho do Altar; \& hutas cafas para oSenhor do Engenho, con? feu Quarto feparado para os Hofpedes, que no Brafil, falto totalmente de Eftalagens, faó continuos ; \& o Edificio do Engenho, forte, \& efpaçofo, com as mais Officinas , \& cafa de purgar, Caixaria, Lambique; \& outras coufas, que por mitidas, aquife efcufa apontallas, \& dellasfe fallara em feu lugar.

O que tudo bem confiderado: aflim como obriga a huns Homens de baftante cabedal, \& de bom juizo, a quererem antes fer Lavradores poffantes de Canna, com hum, ou dous Partidos de mil pães de Affưcar, com trinta, ou quarenta EIcravos de'enxada, \& fouce; do que fer Senhores de Engenho por poucos annos, com a lida, \& attençaó, que pede o governo de todaeffa fabrica: affim he para pafmar, como hoje fe atrevem tantos a levantar Engenhocas, tanto que chegâraó teralgum numero de Efcravos, \& achâraó quem lhes empre. itaffe alguma quaritidade de dinheiro, para começar a tratar de húa obra, deque naó faó capazes por falta de governo, \& de agencia ; \& mutu mais por ficarem logo na primeira fafra tam empenhados com dividas, que na fegunda ou terceiraj fe declaraó perdidos: fendo juntamente caufa, que os que fì̀raó delles dando-1hes fazenda, \& dinheiro, tambem que wrem; \& q́ outros zombem da fua mal fundada prefumpçaó, que tam depreffa converteo em palha fecca aquella priniei. ra verdura de hūa apparente, mas enganofa efperança.

A 2 Eain 
E ainda que nem todos os Engenhos f́jaó Reaes, nem todos puxem por tantos gaftos, quantos atè aqui temos apontado: com tudo, entenda cada qual, que com as mortes, \& fugidas dos fervos, \& có a perda de muitos Cavallos, \& Boys, \& com as feccas, que de improvifo apertaó , \& mirraó a Can na, \& com os defaftres, que a cada pafso fuccedem; crecem os gaftos mais do que fe cuidava. Entenda tambem, que os Pedreiros, \& Carapinas, \& outros Officiaes defejofos de ganhará cufta alhea, lhe facilitaràó tudo de tal forte, que lihe parecerá o mefmolevantar hum Engenho, que hũa fanzalla de Negros: \& quãdo começar a ajuntar os aviamentos, acharâ ter já defpendido tudo o que tinha, antes de fe. pôr pedra fobre pedra, \& naó terá com ó pagar as foldadas ; crecendo de improvifo os gaftos, como por caufa das enxurradas os Rios.

Tambem, fe naó tiver a capacidade, modo, \& agencia, que fe requer, na boa difpofiçá, \& governo de tudo, na eleiçaó dos Feitores, \& Officiaes, na boa correspondencia com os Lavradores, no trato da gente fujeita, na confervaçaó, \& lavoura das Terras, que poffue, \& na verdade, \& pontualida. de com os Mercadores, \& outros feus Correfpondentes na Praça; achará confufaó, \& ignominia no Titulo de Senhor de Engenho, donde efperava acrecentamento de eftimaçaớ; \& de credito. Por iffo, tendo jà fallado do que pertence ao cabedal, que ha de ter; tratarei agora de como fe ha de haver. no governo: \& primeiramente da compra, \& confervaçaó das Terras, \& feus Arrendamentos aos Lavradores, q́ tem : \& logo da eleiçaó dos Officines, que ha de admittir a feu ferviço; apontando as obrigaçoens; $8 \mathrm{r}$ as foldadas de cada hum delles, conforme o eftylo dos Engenhos Reaes da Bahia : \& ultima-: mente do governo domertico da fira familia, Filhos, \& Efcravos, recebimento dos Hofpedes, \& pontualidade em dar fatistaçaó a quem deve; do que depende a confervaçaó do feu credito, que he o melhor cabedal dos que fe prezaố de honrados. 


\section{Opulencia do Brafil.}

18

\section{A P I T U L O II.}

Como se ba de haver o Seniljor do Engenho na compra, Ẽ conjervaçaó das Terras, E๐ nos Arrendamentos dellas.

E o Senhor do Engenho naŏ conhecer a qualidade das $\checkmark$ Terras, comprarà Saloês por Maffapés, \& 'Apicús por Saloens. Por iffo, valha-fe das informaçoens dos Lavradores mais entendidos: \& attente naó fómente á barateza do preço, inas tambem a todas as conveniencias, que fe haó de bufcar, para ter Fazenda com Cannaveaes, Paftos, Aguas, Roças, \& Mattos; \& em falta deftes, commodidade para ter a lenha mais perto, que puder fer, \& para efcufar outros inconvenientes, que os velhos lhe poderáó apontar, que faó os Meftres, a quem enfinou o tempo, \& a experiencia, oque os moços ignoraó.

Muitos vendem as Terras, que tem, por cançadas, ou faltas de lenha : outros, porque fe naó atrevem a ouvir tantos recados, femelhantes aos que fe davaó a Job, do Partido queimado, dos Boys atolados, dos Efcravos mortos, \& do Affucar perdido. Outros obrigados a vender contra vontade por caufa dos Acredores, q̃ os apertaó, bem póde fer que offereçaó Terras novas, \& fortes; porèm ocomprador corre entaô outro rifco de comprar demandas eternas, pelas obrigaçoés, \& hypothecas, a que eftaó por repetidas viezes fujeitas. Por tanto neffe cafo falle o comprador com os Letrados: pergunte aos Acredores, que he o que pertendem; \& fe for neceffario, com authoridade do.Juiz cite a todos, para faber oque a verdade fe deve: nem conclua a compra, antes de ver com $\mathrm{A}_{3}$ feus 


\section{Cultura,}

feus olhos, que he o que compra; que titulos de dominio tem o vendedor, \& fe os ditos bens faó vinculados, ou livres: \& fe tem parte nelles Orfaós, Mofteiros, ou Igrejas; para que fe naô falte ao fazer da efcritura a alguma condiçaó, ou folennidade neceffaria. Veja tambem as demarcaçoens das Terras; fe foraọ medidas por Juftiça; \& fe os Marcos eftaó em fer, ou fe ha mifter aviventallos : que taes faố os Cohereos, a faber, fe amigos de juftiça, de verdade, \& de paz; ou pe. lo contrario trapaceiros, defenquietos, \& violentos: porque naó ha peyor pefte, que hum mao vizinho.

Feita a compra, naó falte a feu tempo á palavra, que dco; pague, \& feja pontual nefta parte : \& attente á confervaçaó, \& melhoramento do que comprou, \& principalmente ufe de toda a diligencia, para defender os Marcos, \& $2 s$ Aguas, de á necefita para moer o feu Engenho: \& moltre aos Filhos, \& os Feitores os ditos Marcos; para q̃ faibaó o que lhes pertence, \& poffaó evitar demandas, \& pleitos, que faó hũa continua defenquietaçaó da Alma, \& hum continuo fangrador de rios de dinheiro, que vay a entrar nas cafas dos Advogados, Solicitadores, \& Efcrivaens, com pouco proveito de quem promove o pleito, ainda quando aleança, depois de tantos gaftos. $\& x$ defgoftos, em feu favor a fentença. Nem deixe os papeis, \& as efcrituras, que tem na caixa da Mullher, ou fobre hüa meza. expofta ao pó, ao vento, á traça, \& aocopim; para que de pois naó feja neceffario mandar dizer muitas Miffas a Santo Antonio, para achar algum papel importante, que defappareceo, quando houver mifter exhibillo. Porque lhe acontecerá , que a Criada, ouserva tire duas, ou tres folhas da caixa da Senhora, para emburulhar com ellas o que mais the agradar: \& o Filho mais pequeno tirará tambem algumas da me$\mathrm{za}$, para pintarcaretas, ou para fazer barquinhos de papel, em que naveguem mofẹas, \& grillos: ou finalmente o vento fará, que voem fóra da cafa fem pennas.

Para 


\section{- EOpulencia do Brafl.}

Para ter Lavradores obrigados ao Engenho, he neceflario paffarlhes Arrendamento das Terras, em que haó de plantar. Eftes coftumaó fazer-fe por nove annos, \& hum de defpejo, com obrigaçaó de deixaré plantadas tantas Tarefas de Cannạ: ou por dezoito annos, \& mais, com as obrigaçoens , \& numerode Tarefas, que affentarem, conforme o coftume da Terra. Porém ha-fe de advertir, que os que pedem arrendamento, fejaó Fazendeiros, \&z naó deftruidores da Fazenda ; de forte, que fejaó de proveito, \& naó de dano. E na Efcritura do Arrendamento fe háo de pôr as condiçoés neceffarias: v v.g. que naó tirem paos reaes : que naó admittaó outros em feut ligar nas Terras, que arrendaó, fem confentimento do Senhor dellas : \& outras, que fe julgarem neceffarias, para que algum. delles, mais confiado, de Lavrador fe naó faça logo Senhor. E para iffo feria boa prevençaó, ter hŭa formula, ou nota de Arrendamentos, feita poralgum Letrado dos mais experimentados, com declaraçaó de como fe haveráó defpejando, acerca das Bemfeitorias; para que o fim do tempo do Arrendamento naó feja principio de demandas eternas.

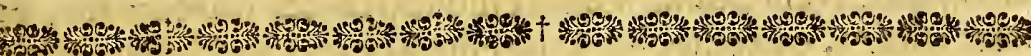

\section{A P I T U I O III.}

Como se ba de haver o Senhor do Engenho com os Les: vradores, Go outros vizinbos; Gs estes com 0 Senbor.

Ter muita fazenda cria, cómummente nos homens ri: cos, \& poderofos, defprezo da gente mais nobre : \& por iffo Deos facilmente lha tira, para que fe naó firvaó della pa. ra crecer em foberba. Quem chegou a ter titulo de Senthor, parece, que em todos quèr dependencia de fervos. Eifto priń$\mathrm{A}_{4}$ cipal- 


\section{Cultura;}

cipalmente fe vè em alguns Senhores, que temLavradores $\mathrm{em}$ Terras do Engenho, ou de cannz obrigada a moer nelle; tratando-os com altivez, \& arrogancia. Donde nace o ferem malquiftos, \& murmurados dos que os naó podem fofrer: \& que muitos fe alegrem com as perdas, \& defaftres, que de repente padecem ; pedindo os miferaveis opprimidos a cada paffo juffiç̧a a Deos, por fe verem tam avexados; \& defejando ver aos feus oppreffores humilhados, para que aprendaō a naó tratar mal aos humildes : affium como o Medico defeja, \& procura tirar fóra a malignidade, \& abundancia do humop peccante, que faz ao corpo indifpofto, \& doente; para lhe dar defta forte naó fómente vida, mas tambem perfeita faude.

Nada pois tenha o Senhor do Engenho de altivo; mada de arrogante, \& foberbo: antes feja muito affavel com todos; \& olhe para os.feus Lavradores, como para verdadeiros amigos; pois taes faó na verdade, quando fe defentranhaó, para trazerem os feus Partidos bem plantados, \& limpos, com grande emolumento do Engenho: \& délhes todo o adjutorio, que puder, em feus apertos, affim com a authoridade, como com a fazenda. Nem ponha menor cuidado em fer muito jufto, \& verdadeiro, quando chegar o tempo de moer a Canna, \& de fazer, \& encaixar os Affucares: porque naó feria juftiça tomar para fi os dias de moer, que deve dar aos Lavradores por feuturno; ou dar a hum mais dias, que a outro; ou mifturar - Affucar, que fe fez de hum Lavrador, com o da Tarefa de outro; ou elcolher para fi o melhor, \& darao.Lavrador of fomenos. E para evitar eftas duvidas, \& qualquer outra fufpeita femelhante, avife, ou mande avifar com tempo a quen. por dircito fe fegue, para que poffa cortar, \& carrear a Canna, \& tella na Moenda ao feu dia : \& haja nas. Formas feu final, para que fe diffingaó das outras. Nem effranhe, que os. Lavradores queiraó ver no Tendal, \& Cafa de purgar, no Balcaó, \& Cafa de encaixar, a co feu Afiucar; pois tanto lhes.

cuftou 


\section{Copulencia do Brafll.}

cuftou chegallo a pôr neffe eftado, \& tanta amargura precedeo a efta limitada doçura.

Tambem feria final de ter ruim coraçaó, fazer mà vizinhança aos que moem a Canna livre em outros Engenhos, fó porque a naô moem no feu: nem ter boa correfpondencia com os Senhores de outros Engenhos, fó porque cada qual delles folga de moer tanto, como outro; ou porque a algum delles lhe vay melhor, com menos gafto, \& fem perdas. E fe a envejá entre os primeiros Irmáos, que houve no Mundo, foy tam arrojada, que chegou a enfanguentar as mãos de Caim com o fangue de Abel, porque Abel levava a bençaớdo Ceo, \& Caim naó, por fua culpa: quem duvîda, que poderia chegar a renovarfemelhantes Tragedias ainda hoje entre os parentes; pois ha no Brafil muitas paragens, em que os Senhores de Engenho faó entre fi muito chegados por fangue, \& pouco tunidos por charidade, fendo o intereffe a caufa de toda a dif cordia, \& baftando tal vez hum pao quefe tire, ou hum Boy que entre em trum Cannaveal por defcuido, para declararo: odio efcondido, \& para armar demandas, \& pendencias mortaes? O unicoremedio pois, para atalhar pezados defgoftós, he haver-fe com toda a urbanidade, \& primor; pedindolicença para tudo; cada vez que for neceffario valer-fe do que tem os vizinhos: \& perfuadirfe, que fe negaó o que fe pede, ferá, porque a neceffidade os obriga. E quando ainda fe co. nheceffe, quie o negar-fe he por defprimor; a verdadeira, \& mais nobre vingançaferá, diar logo a quem negou o que fe pedio, na primeira occafiaó dobrado do que pede, para que de fta forte caya por bom modo na cóta de como devia proceder.

Sobre todos porèm os que fe devem haver com mayor refpeito para com oSenhor do Engenho, faó os Lavradores, que: tem Partidos obrigados à fua Moenda ; \& muito mais os que lavraó em Terras, que o Senhor lhes temarrendado: particularmente, quando defta forte começâraó fua vida, \& chegâ. 


\section{so}

\section{Cultura;}

raó por efta via a ter cabedal; porque a ingratidaó, \& o faltar ao refpeito, \& cortezia devida, he nota digna de fer muito eftranhada: \& hum agradecimento obfequiofo cativa aos animos de todos com correntes de ouro. Porén efte refpeito núca hade fer tal, que incline a obrar contra juttiça, principalmente quando folfem induzidos a fazer coufa contraria á ley de Deos : como feria, a jurar em demandas crimes; ou civeis contra a verdade, \& a por-fe mal com os que com razaó fe defendem. E o que tenho dito dos Senhores do Engenho, digo tambem das Senhoras : as quaes, pofto que mereçaó mayor refpeito das outras, naó haoo de prefumir, que devem fer tratadas como Rainhas; nem que as.Mulheres dos Lavradores háo de fer fuas Criadas, \& apparecer entre ellas como a Lua entre as Eftrellas menores.

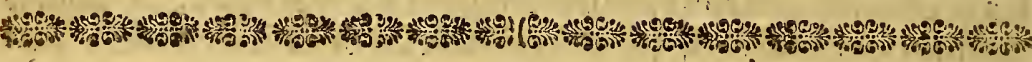

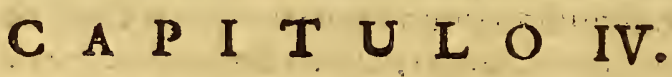 \\ Como se ba de baver o Senbor do Engenbo na elei= sao das Peßsoas, Eั Officiaes, que admittir ao feu fervigo: Es primeiramente da eleiçāo}

E em alguma coufa mais que em outra, ha de moftraro $\checkmark$ Senhor do Engenho a fua capacidade, \& prudencia ; efta fem duvida he a boa eleiçaó das Pefloas, \& Officiaes, que ha de admittir ao feu ferviço para o bom governo do Engenho. Porq́ fendo a eleiçaó filha da Prudencia ; com razaó fe arguirá de imprudente, quem efcolher Peffoas; ou de ruin vida, ou ineptas para o que haó de fazer. Eclaro eftá, que huns com a ruim vida delagradaráó a Deos, \& aos homens, \& foráó caufa de muitos, \& bem pezados defgoftos; \& outros 


\section{EOpulencia do Brafll.}

com a ̣̂neptidaó caufaráó dano naô ordinario â Fazenda. E ifto lhe poderáó eftranhar com razaó, naó fó os de cafa por mais chegados a queimarfe, ou a chamuícar- fe eữ ô feit trátö: mas tambem os de fóra : \& principalmente os Lavradores; obrigados a experimentar fem culpa os prejuizos, que fe feguem aofeu malogradofuor; de naó faberem os Officiaes.o que requer ofeu Officio.

O primeiro, que fe hade efcolher com circunfpeeçaó, \& informaçaó fecreta do feu procedimento, \& faber, he o Capellaó, a quem fe ha de encomendaro enfino de tudo oque pertenceá vida Chriftaã ; para defta forte fatisfazer á mayor das obrigaçoês, que tem: a qual he đoutrinar, ou mandar doutrinar a familia, \& Efcravos, naó.jà por hum Crioulo, ou por hum Feitor, que quando muito poderà enfinarlhes vocalmente as Oraçoens, \& os Mandamentos da Ley de Deos, \& da Igreja; mas por quem faiba explicarlhes o que hăo de crer; o que hão de obrar, \& como haó de pedir a Deos aquillo, de que necefitaó. E paraiffo fe tor neceffario dar ao Capellaó alguma coufa mais do que fe coftuma; entenda, que efte ferà o. melhor dinheiro, que fe darà em boa maố.

Tem pois o Capellaó obrigaçaó de dizer Miffa na Ca: pella do Engenho nos Dómingos, \& dias fantos, ficandolhe livre a applicaçaó das Miffas nos outros dias dia fenrana por quem quizer : falvo fe fe concertar de outraforte com o Se. nhor da Capella,recebendo eftipendio proporcionado ao tra balho. E nos mefmos Domingos, \& dias fantos, ou pelomenos nos Domingos, fe fe admittir com efta obrigaçaó, explicarà aDoutrina Chriftaã, a faber os principaes myfterios da Fé, \& o que Deos., \& a Santa Igreja mandaó, que fe guarde. Quam grande mal he o peccadio mortal : Que penalhe tem Deos aparelhado nefta, \& $\mathrm{n}$ na outra vida, aonde a Alma vive, \& vivirâ immortalmente. Que remedio nos deo DeosnaEn: carnaçaó, \& Morte de Jefu Chrifto feu Santiflimo.Filho,para 


\section{2}

\section{Cultura:}

que fe nos perdoaffem affim as culpas, como as penas, que pelas culpas fe devem pagar. De que modo havemos de confeffar os peccados, \& pedir a Deos perdaó delles com verdadeiro arrependimento, \& propofito firme de naó tornar a commettellos, ajudados da graça divina. Em queconfifte fazer penitencia de feus peccados. Quem eftá no Santifimo Sacramento do Altar: Porque eftá ahi, \& fe recebe : Com que difpofiçaó fe hade receber em vida, \& por Viatico na doença mortal. Quanto importa ganhar as Indulgencias, para defcontar o que fe deve pagar no Purgatorio. Como cada qual fe ha de encomendar a Deos para naó cahir em peccado, \& offerecerlhe pela manháa todo o trabalho do dia. Quanto faó dignos de abominaçaó os Feiticeiros, \& Curadores de palavras, \& os que a elles recorrem, deixando a Deos, de quem vem todo o remedio: os que daó peçonba, ou bebidas (como dizem') para abrandar, \& inclinar as vontades : os Borrachos; os Amancebados, os Ladróes, os Vingativos, os Murmuradores, \& os quejuraó falfo, ou por malignidade, ou por interefle, ou por refpeitos humanos. E finalmente que premio, \& que pena ha de dar Deos eternamente a cada qual, conforme obrou nefta vida.

Procurará tambern a approvaçaó para ouvir de confiflaó aos feus Applicados ; \& para que fendo Sacerdote, \& Miniftrode Deos, thes poffa fervir frequentemente de remedio; naó fe contentando fó com acudir no artigo da morte aos doentes. Mas advirta na adminiftraçaó defte Sacramento, que naó he Senhor delle, por muita authoridade que tenha : porque fe o Penitente naó for difpofto, por caufa de eftar amancebado, ou andar com odio do proximo, ou por naó tratar de reftituir a fama, ou a fazenda, que deve; ainda que fofle.o mefmo Senhor do Engenho, o naó ha de abfolver : \& nifto poderia haver, por refpeito humano, grande encargo de côfciencia, \& culpa bem grave.

Corre 


\section{GOpulencia do Brafil.}

Corre tambem porfua conta pôr a todos em paz, \& atas Ilyr difcordias: \&x procurar, que na Capella, em que affifte, feja Deos honrado, \& a Virgem Senhora noffa, cantandolhe nos Sabbados as Ladainhas ; \& nos mezes, em que o Engenho naó moe, o terço do Rofario : naó confentindo rifadas, nem converfaçoens, \& praticas indecentes, naófó na Capella, mas nemianda no Copiar, particularmente quando fe celebra ofanto Sacrificio da Miffa:

Advirta alem difto de naó receber Noyvos, nem Gautizar fóra de algum cafo de neceffidade, nem defobrigar na Quarefima peffoa alguma, fem licença in fcriptis do Vigario, a quem pertencer dalla , nem fazer coufa, que toque á jurifdiç̧aó dos Parocos; para que nä́ encorra nas penas, \& cenfuras, que fobre iffo faó decretadas; \& de balde fe queixe do feu defcuido, ou ignorancia.

Finalmente faça muito por morar fóra de cafa do Senhor do Engenho: porque afim convém a ambos; pois he Sacerdote; \& naó Criado, familiar de Deos, \& năo de outro homem : nem tenha em cafa Efcrava para o feu ferviço, que naó feja adiantada na idade: nem fe faça Mercador ao divino, ot ao humano; porque tudo ifto muito fe oppoem ao éftado $\mathrm{Cle}_{-}$ rical, que profeffa, \& fe lhe prohibe por varios Summos Pontifices.

O que fe cofúma dar ao Capellaó cad̆a anno pelo feu trabalho, quando tem as Miffas da femana livres, fáó quarenta, ou cincoenta mil reis : \& com o que lhe daó os Applicados, vem a fazer hũa porçaó competente, bem ganhada. fe guardar tudo o q̃ acima étá dito. E fe houver de enfinar aos filhos doSenhor do Engenho, fe lhe acrecentará o que for jufto, \& correfpondente ao trabalho.

No dia, em que fe bota a Canna a moer, fe o Senhor do Engenho naõ convidarao Vigario; o Capellaó benzerá o Engenho ; \& pedirá a Deos, que dè bom rendimento , \& livre 
aos quie nelle trabalhaó de todo odefaftre. E quando no fim da fafra o Engenho pejar; procurará, que todos dem a Deos as graças na Ciapella.

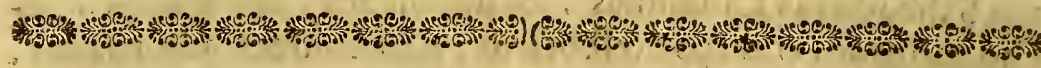

\section{A P I T U L O V.}

Do Feitor Mór do Engenbo, Eं dos outros Feitores menores, que afffem na Moenda, Fazendas, Eo Partidos da Canna: Suas obrigagoens,

\section{Eo joldadas.}

S braços, deque fe valo Senhor do Engenho, para o bom governo da Gente, \& da Fazenda, faó os Feitores. Porém, fe cada hum delles quizer fer cabeça, ferá o ga verno monítruofo, 80 hum verdadeiro retrato do Caõ Cerbero, a quem os Poetas fabulofamente daó tres cabeças. Eu naō digo , que fe naó dé authoridade aos Feitores: digo, que. efta authoridade ha de fer bem ordenada, $\varepsilon \tau$ dependente, naó abfoluta; de forte, que os mencres fé hajaó com fubordina€̧aó ao mayor, \& todos ao Senhor, a quem fervem. Convem, que os Efcravos fe perfuadaó, que o Feitor Mór tem muito poder para thes mandar; \& para os repiehender, \& caftigar, quando for neceffario: porém de tal forte, q́ tambem.faibaó, que podem recorrer ao Senhor; 8 q́ haó de fer ouvidos, como pede a juftiça. Nem os outros Feitores, por terem mando, hăó de crer, que o feu poder naố he coartado, nem limitado, principalmente no gue he caftigar, \& prender. Por tanto oSenhor ha de declarar muito bem a authoridade, que dá a cada hum delles, \& mais ao Mayor: \& fe excederem, ha de puxar pelas redeas com a reprehenfaó; que os exceffos merećém: mas naō diante dosEfcravos, para que outra vez fe naỏ levantem contra O Feitor; \& efte leve a mal de fer rcprehendido diante 


\section{¿O Opulencia do Brafl.}

diante delles; $\&$ fe naóatreva a governallos Só baftarà, que por terceira peffoa fe façaentender ao Efcravo, que padeceo, \& a alguns outros dos mais antigos da Fazenda, que o Senhor eitranhou muito ao Feitor o exceffo, que commetteo; \& que quando fe naó emende, o ha de defpedir certamente.

Aos Feitores de nenhuma maneira fe deve confentir o dar conces, principalmente nas barrigas das Mulheres, que andaó pejadas; nem dar com pao nos Efcravos : porque na ca. lera fe na6 medem os golpes; \& podé ferir mortalmente na ça. beça a hum Efcravo de muito preftimo, que val muito dinhei. ro, \& perdello. Reprehendellos, \& chegarlhes com hum cipó âs coftas com algumas varancadas, he o que fẹthes póde, $\&$ deve permittir para enfino. Prender os fugitivos, \& os que brigâraó com feridas, ou fe embebedáraó, para que o Senhor os mande caftigar, como merecem; he diligencia digna de louvor. Porém anarrar, \& caltigar com cipó, até correro fañgue ; 8 meterno tronco, ou em húa corrente por mezes (eftando o Senhor na Cidade) a Ef́crava, que não quiz confentirno peccado; ouao Efcravo, que deo fielmente conta: da infidelidade, vialencia, \& crueldade do Feitor, que para if fo armou delitos fingidos: ifto de nenhum modo fe ha de fofrer; porque feria ter hum Lobo carniceiro, $3 x$ naó hum Feì tor moderado, \& Chriftaó.

Obrigaçaó do FeitorMór doEngenho he governara gen te, \&c repartilla a feu tempo, como he bem, para o ferviço. A elle pertence faber do Senhor, a quem fe ha de avifar para que corte a Canna; \& mandarlhe logo recado. Tracar de aviar os Barcos, \& os Carros parabufcar a Canna, formas, \& lenha: Dar conta aoSenhor de tudo o que he neceffario para o apa. relho do Engenho, antes de começara moer; \& logo acaba. da afafra, arrumar tudo em feu lugar. Vigiar que ninguem falte árú obrigaçaó: \&racudir depreffa aquaiquer defaftre, q́ fucceda, para lhe dar, quăto puder fer, oremedio.Adoecendö 


\section{Cultura,}

qualquer Efcravo, deve livrallo do trabalho, \& pôr outro em feu.lugar: \& dar parte ao Senhor, para que trate de 0 mandar curar ; \& ao Capellaó, para que o ouça de confiflaó, \& o difponha, crecendo a doença, com os ma is Sacramétos para morrer. Advirta, que fe naó metaó no carro:os Boys, que trabaIháraó muito nos dias antecedentes : \& que em todo o ferviço aflim como fe dá algum defcanço aos Boys, \& aos Cavallos; aflim fe dé, \& com mayor razaõ, por fuas efquipaçoens aos Efcravos.

O Feitor da Moenda chama a feu tempo as Ef́cravas, recebe a Canna, \& a manda vir, \& neter bem nos Eixos, \& tiraro bagaço:attentando, q́ as Negras naó durmão, pelo perigo que ha, de ficarem prezas, \& moidas, fe lhes naó.cortarem as mãos, quando ifto fucceda ; \& mandando junta. mente divertir a agua da Roda, para que pare. Procura, que devinte \& quatro em vinte \& quatro horas fe lave a Moenda, \& que o Caldo vá limpo, \& re guinde para o Paról. Pergunta quanto $\mathrm{Caldo}$ ha mifter nas $\mathrm{Caldeiras,} \mathrm{para} \mathrm{que} \mathrm{faiba} \mathrm{com} \mathrm{efte}$ avifo, fe ha de moer mais Canna, ou parar, atè que fe dévazaó, para que naó azecie o que jâ entá no Paról.

Os Feitores, que eftaó nos Partidos, \& mais Fazendas, tem à fua conta defender as Terras : \& avifar logo ao Senhor, e ha quem fe metta dentro das Roças, Cannaveaes, \& Mattos, para tomar o quie naó he feu. Affiftir aonde os Efcravos trabalhaó, para que fe faça of ferviço, como he ben. Saber os tempos de plantar, limpar, \& cortar a Canna, \& de fazer Rcças. Conhecer a diverfidade das Terras, que ha, para fervirfe dellas para o que forén capazes de dar. Tomar a cada Efcravo a $T$ arefa, 8 ras máos, que he obrigadoentregar. Attentar para os caminhos dos Carros, que fejaó taes, que por elles fe pofta conduzir a Canna,\& a lenha, de forte que naó fiquem na lama: \& que tambem os Carros fe concertem quando for neceffario. Ver, que cada Efcravo tenha fua fou: 


\section{EO Opulencia do Brafil.}

ce, \& enxada, \& o mais, que ha mifter para o ferviço. E efteja muito attento, que fe naó pegue o fogo nơs Cannaveaes por defcuido dos Negres boçaes, que ás vezes deixaó ao vento o tiçaó đé fogo, que levâraó comfigo para ufarcm do caa chimbo: \& em vendo qualquer lavareda, acuda-lhelogo com toda a gente, \& corte com fouces o caminho á cháma, que vay crecendo; com grande perigo de fe perderem em mèya hora muitas Tarefas de Canna.

Ainda que fe faiba a Tarefa da Canna, que hum Negro ha de plantarem hum dia, \& a que ha de cortar; quantas Covas de Mandioca ha de fazer, \& arrancar; \& que medida de lenha ha de dar, como fe dirá em feu lugar: com tudo, haó de attentar os Feitores à idade, \& ás forças de cada qual ,para diminuirem o trabalho aos que elles manifeftamente vem, que naó podem com tanto: comofaó as Mulheres pejadas depois de feis mezes, \& as que ha pouco que parîraó, \& criaó. os velhos, \& as velhas; \& os que fahírió ainda convalecentes de algŭa grave doença.

Ao Feiror Mór daó nos Engenhos Reaeśfeffenta mil reis. Ao.Feitor da Moenda; aonde fe moe por fete, 8 roito mezes, quarenta, ou cincoenta mil reis, particularmente fe fé lhe encomenda algum outroferviço: mas aonde ha menos que fazer, \& naó fe occupa em outra coufa, daó trinta mil reis. Aos que affiftem nos Partidos, \& Fazendas, tambem hoje, aonde a lida he grande, dao quarenta, ou quarenta \& cinco mil reis.

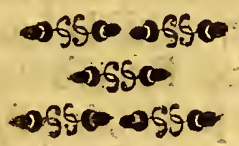

B

C A- 


\section{8}

\section{Cultura,}

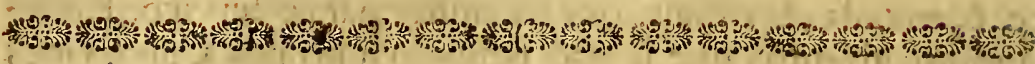

$$
\therefore \text { A P I T U L O VI. }
$$

Do Meftre do Affucar, E⿱ Soto-meftre a quem cbas maò Banqueiro, $E^{\circ}$ do Seu Ajudaste, a quem. chamä Ajudabanqueiro.

A Quem faz o Affucar, com razaó: fe dáo nome de MeA. ftre; porque o feu obrar pede intelligencia, attençaó, \& experiencia: \& efta, naố bafta quefeja qualquer; mas he. neceffaria a experiencia local, a faber, do higar, \& qualidade da Canna, aondefe planta, \& femoé: porque os Cannaveaes de hứa parte, daó Canna muito forte; \& déoutra, muito fraca. Diverfo çumo tem a Canna das Varzeas, do que tem a.dos Outeiros: a das Varzeas vem muito aguacenta, \& o caldo della tem muito que purgar nas Caldeiras, \& pede mais decoäda: a dos Outeiros vem bé affucarada, $\&$ ofeu caldo pede menos tempo, \& menos decoada para fe purificar $;$ \& clarificar. Nas Tachas ha Melado, que quer mayor cozimento; \& ha outro de menor: hum, logo fe condenfa na batedeira: outro, mais de vagar. Das.tres T emperas, que fe hao de fazer para encher as formas, depende o purgar-fe o Afiucarbiem, ou mal, conforme ellas faó. Se o M eftre fe fiar dos Caldeireiros, $\&$ dos Tacheiros, húas vezes cançados, outras fonorentos, \& outras alegres mais do que convém, \& com a cabeça efquentada; acontecerlhe-ha ver perdida hüa, \& outra Meladura, fem lhe poder dar remedio. Porifio vigie em coufa de tanta importancia : \& fe o Banqueiro, \& o Ajudabanqueiro naó tiverem a intelligencia, \& experiencia neceffaria para fuppi irem em fua aufencia; naó defcance fobre clles: enfine-os, avife-os, \& fe for neceffario, reprehenda-os, pondo-lhes diante 


\section{EO Opulenciado Braßl.}

dos al hos o prejuizo do Senhor do Engenho, ; dos Lartadores, fe fe perder o Molado nas Tachas; on fe for mal tenperadopara -as Formas.

Veja,que o Feitor dxMoenda modêre de tal forte o moer, quel he naố venha ao Pa ról mais caldo do que ha mifter; para the poder darvazáó antesque fe comece a ażedar, purgando-o, cozendo-o; \& batendo-o, quanto he neceffario.

Antes de fe botara decoada nas Caldeiras do caldo, experimente, quetal cellahe; \& depois veja, como os Caldeireiros a botaó, \& quando haó de parar: nem confinta, que a Meladura fe coe, antes dever, fe o caldoeftá purificado, como hade fer : \& o mefmo digo da paffagem de hũa para outra Tacha, quando fe hade cozer $;$ \& bater sendo a alma de todo obom fucceffo a diligente attençaó.

A jurfiça, \& a verdade o obrigaб a naŏ mifturar o Affucar de hum Lavrador comodo outro : \& por iffonas. Formas? que manda pốr no Tendal, faça, que haja final com que fe póflaó diftinguir das outras, que pertencen a outros donos, para que o Meu, \&oTeu, inimigos da paz, naó fejaó caufá de bulhas. E para que a fua obra feja perfeita, tenha boa correfpondencia com o Feitor da Moenda, que lhe envia o Caldo; como Banqueiro, \& Sotobaniqueiro, que lhe fuccedem de noite no officio; \& com o Purgador do Affucar; para que vejaó juntamente donde nace o purgar bem, ou mal em as Formas : \& fejaó entrefí como os olhos, que igualmente vigiaó ; \& como as mãos, que unidamente trabalhaó.

O que atéagora efá dito, pertence em grande parteao Banqueiro tambem, que he o Soto-meftre, \& aoSoto-ban queirofeu Ajudante. E alem diffo pertence a eftes dous Officiaes ter cuidado do Tendal das Formas, de taparlhes os buracos, cavarthes as covas de bagaço comi cavadores; endireitallas; \& botarnellas o Affucar feito com as tres Tempeas; das quaes fe fallarà em feu lugar : \& depois de tres dias; $\mathrm{B}_{2}$ enviallas 


\section{Cultura,}

enviallas para a Cafa de pargar, ou fobre paviolas, ou às co. tas dos Negros; para que o Purgador trate dellas.

Devem tambem procurar, que fe faça a répartiçaójuifta dos claros entre os Efcravos, conforme o Senhor ordenar; \& - que nefta Cafá haja toda a limpeza, \&r claridade; agua, de= coada, \& todos os.inftrumentos, dos quàes nella fe ufa. Ea Meftre pertence ver, antes de começar o Engewho moer, fe os fundos das Caldeiras, \& das Tachas ten neceffidade de fe refazerem; \& fe os affentos dellas pedem novo, \& mais firme concerto.

A foldada do Meftre de Affucar nos Engenhos, que fazem:quatro ou cinco mil paés, particularmentè fe elle vifita tambem a Cafa de purgar, he de cento \& trinta mil reis : em outros daó-lihe fó cem mil reis. Ao Banqueiro nos mayores, quarenta mikreis; nos menores, trinta mil reis. Ao Sorobanqueiro (que cómummente he algum Mulato; ou Crioulo Écravo de cafa) dá fe tambem no fini da fáfra algum mimo, fe fervio com: farisfaçaó no feu officio; para que a efperança defte limitado premio o alente fiavemente para o trabalho.

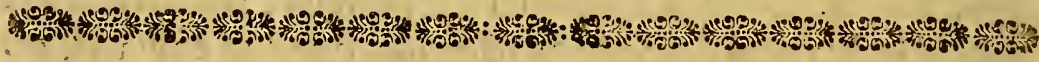

\section{A P I T U L O V II.}

\section{Do Purgador de Aßucar.}

A. O Purgador do Affucarpertence vero barro, que vem 1 para o girao a feccar-fe fobre oCinzeiro, fe he qual deve fer, como fe dirá em feu lugar: ol har para o Amafiador, fe anda, como deve, com o Rodo no Cocho: furar os Paens nas Formas, \& levantallas. Conhecer, quando o Affucareftá enxuto, \& quando he tempo del lhe botar o primeiro barro; \& co. moefte fe hade, cltender, \& quanto tempo fe ha: de deixar: antes de: lhe botar o fegundo ; como fe lhe haó de dar as humir 


\section{¿s Opulencia do Brafl.}

dades, ou lavagens, \& quantas fe lhe haó de dar: \& quaes faó os finaes de purgar, ou naó purgar bem o Affucar, conforme as diverfas qualidades, $\&$ temperas. A elle tambem pertence ter cuidado dos Meles, ajuntallos, cozellos, \& fazer delles. Batidos; ou guardallos, para fazer Agua ardente. Deve juntamente ufa de toda a diligencia, para que fe naó fujem os. Tanques do $\mathrm{Mel} ; \&$ de alguma induftria parar afugentar aos Morcegos, que cómúmente faó a praga quafi de todas as $\mathrm{Ca}$ fas de purgar.

Ao Purgador de quatro mil Paés de Affucar dá-fe foldada de cincoenta mil reis. Aos que tem menos trabalho dá-fe tambem menos, com a devida proporçaó.

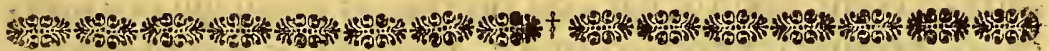

\section{A P I $T U$ U O VIII.}

\section{Do Caixeiro do Engenho.}

Queaqui fe dirá, naô pertence ao Caixeiro da Cidade, porque efte trata fó de receber o Affucar já encaixa. do, de o mandar ao Trepiche, de o vender, ou embarcar. conforme o Senhor dó Engenho ordenar : \& tem Livro de razaō de dar, \& haver : ajufta as contas, \& ferve de Agente, Contador, Procurador, \& Depofitario de feu Amo : ao qual, fe a lida he grande, dá-fe foldada de quarenta ou cincoenta mil reis. Fallo aqui do Caixeiro, que encaixa o Afucar, depois de purgado. E fua obrigaçaố he, mandar tirar o Affue car das Formas, eftando já purgado, \& enxuto em dias claros, \& de Sol: affiftir, quando fe mafcava, \& quando fe bene. ficia no Balcaó de feccar, partindo-o, quebrando-o, como fe dirá em feu lugar. Elle he que péza o Aflucar, \&, que o reparte com fidelidade entre os Lavradores, \& o Senhor do Engenho; \& tira o dizimo, que fe deve a Deos; \& a vintena, ou $\mathrm{B}_{3}$

quinto, 
gunto, que pagaó os quelavias em terras do Engenho, conforme o concerto feito nos Arrendamentos, \& o eftylo ordimario da Terra, o qualem varios lugares he diverfo : \& tudo affenta para dar conta exactamente de tudo. A elle tambem pertence levantar as caixas, \& mandallas barrear nos cantos: encaixar, \& mandar pilar o Aflucar, com a divifaódo Branco Macho, do Batido, \& Mafcavado : fazeras Caras, \& os Fe chos, quando affim lho encomendarem os donos do Affucar: \& finalmente pregar, \& marcar as Caixas; \& guardar o Affucar, que fobejou, para feus donos em lugar feguro, \& naó humido; \& os inftrumentos', de que ufa. Entrega as Caixas, quando fe haó de embarcar, com ordem de quem as re. cada ou como dono dellas, ou porque as alcançou por juftiça, como muitas vezes acontece, fazendo os Acredores pe. nhora no Affucar dos devedores, antes que faya do Engenho: \& de tudo pedirá recibo, \& clareza, para poder dar contade fi a quem lha pedir.

A foldada do Caixeiro nos Engenhos mayores he de quarenta mil reis : \& fe feitoriza alguma parte do dia, ou de noy: te, daó-felhe cincoenta mil reis: nos menores daó trinta mil.

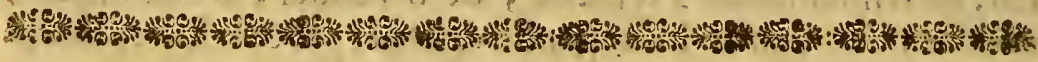

\section{A P, I U U L O IX.}

Como fe hade baver o Senbor do Engenhocom feus. Eforavos.

S Efcravos faó as ínãos, \& $x$ os pés do Senhor do Engenho; porque fen elles no Brafil naô he polfivel fizer, confervar, \& aumentar Fazenda, nem ter Engenho corrente. Edomodo, com que fe hacom elles, depende tellos bons, ou maos para o ferviço. Por iffo he neceffario comprar cada 


\section{Co Opulencia do Brafl.}

anno alginmas Peças, \& repartillas pelos Partidos, Roças; Serrarias, \& Barcas. E porquie cómumniente faó de $N$ açoens diverfas, \& huns mais boçaes que outros, \& de forças muito differentes; fe ha de fazer a repartiçaó com reparo, \& efco: tha, \& naó às cegas. Os que vem para o Brafil, faó. Ardas; Minas, Congos, de S.Thomé, de Angola, de Cabo Verde, \& alguns de Moçãbique, ã vem nias Naos daIndia. Os Adas; \& os. Minas faó robuftos. Os.de Cabo Verde, \& de S T homè faõ mais fracos. Os de-Angola creados em Loanda faó mais capazes de aprender officios mecanicos, q́ os das outras partes: já nomeadas. Entre os Congos ha tambem alguns baftanteméte induftriofos, $\&$ bons, náo fómente para a ferviço da Can na, mas para as Officinas, \& para o meneo da cafa.

Huns chegaó ao Brafil muito rudes, \& muito fechados; $\&$ affim continuaó por toda a vida. Outros em poutcos annos raem ladinos, \& efpertos, affim para aprenderem $a D$ Doutrin $a$ Chriftaá, como para bufcarem modo de paffaravida, \& $\& a-$ ra fe lhes encomendar hum barco, para levarem recados, \& fazerem qualquer diligencia das que coftumaô ordinaria mente occorrer. As Mulheres ufaó de fouce, \& de enxada, como os Homens : porém nos Mattos, fómente os:Efcravos ufaó de machado. Dos ladinos fe faz ef́colha para Caldeirei. ros, Carapinas, Calafates; Tacheiros, Barqueiros, \& $\mathrm{Ma}$. rinheiros; porque eftas occupaçoens querem mayor adver: rencia. Os que defde novatos fe metèráo em alguma Fazenda, naó he bem que.fe tirem della contra futa vontade; porque facilmente feamofinao, \& morrem. Os que nacèraó no Brafil, ou fe creâraó defde pequenos em cafa dos Brancos, affeiçoando-fe a feus Senhores, daó boaconta de fi : \& levando bom cativeiro, qualquer delles val por quatro boçaes.

Melhores ainda faó para qualquer officio os Mulatos: porém muitos delles ufando mal do favor dos Senkérés, fáó foberbos, \& viciofos, \& prezaó-fe de valentès, aparelhados

$$
\mathrm{B}_{4}
$$


para qualquer defaforo. E comtudo elles, \& ellas da mefina cor, ordinariamente levaó no Brafil a melhor forte; porque com aquella parte de fangue de Brancos, que tem nas veas, \&. tal-vez dos feus mefmos Senhores, os enfeitiçaó de tal manei$\mathrm{ra}$, que alguns tudo thes fofrem, tudo lhes perdoaó : \& parece, que fe naó atrevem a reprehendellos; antes todos os mimos faófeus. E naớ he facil coufa decidir, fe nefta parte faó mais remiffos os Senhores, ou as Senhoras; pois naó fálta entre elles, \& ellas, quem fe deixe governar de Mulatos, que naó faó os melhores: para que fe verifique o proverbio, que diz: Que o Brafil he Inferno dos Negros, Purgatorio dos Brancos, \& Paraifo dos Mulatos, \& das Mulatas: falvo quando por alguma defconfiança, ou ciume, o amor fe muda em odio, \& fae armado de todo o genero de crueldade, \& rigor. Bom he valer-fe de fuas habilidades, quando quizesem ufar bem dellas, como aflim o fazem alguns; porèm naố fe lhes. ha de dar tanto a maó, que peguenı no braço, 8 ze Efcravos. fe façaó Senhores. Forrar Mulatas defenquietas, he perdiçaó manifefta ; porque o dinheiro, que daó para fe liv rarem, raras vezes fae de outras minas, que dos feus mefmos corpos, com repetidos peccados: $\&$ depois de forras, continuaó a fer ruina de muitos.

Oppoem-fe alguns Senhores acs cafamentos dos Efcravos, \&c Efcravas ; \& naó fómente naó fazem cafo dos feus amancebamentos, mas quafi claramente os confentem, \& Ihes daó principio, dizendo: Tu Fulano a feu tempo cafaràs com Fulana: $\&$ dahi por diante os deixaó converfar entre fi, como fe jà fófem recebidos por Marido, \& Mulher: \& di$z e m$, que os naó cafaó, porque temem que enfadando-fe do cafamento, fe matem logo com peçonha, ou com feitiços; naó faltando entre elles Meftres infignes nefta Arte. Outros, depois de eftarem cafados os Efcravos, os apartaó de tal forte porannos, que ficaó como fe foffem folteiros : o que naó podem 


\section{\& Opulencia do Bra/l.}

podem fazer em confciencia. Outros faó tam pouco cuidadofos do que pertence á falvaçaó dos feus Efcravos, que os tem por muito tempo no Cannaveal, ou no Engenho fem Bautifmo: \& dos bautizados muitos naó fabem, quem he o feu Creador; o que haó de crer ; que ley haó de guardar ; como fe haó de encomendar a Deos; a q́ vaoo osChriftãos á Igreja ; po rq́ adoraó a Hoftia confagrada ; que vaó a dizer ao $\mathrm{Pa}$ dre, quando ajoelhaó, \& lhe fallaó aos ouvidos; fe tem alma; \& fe ella morre,\&para onde vay, quando fe aparta do corpo.E fabendo logo os mais boçaes, como fe chama, \& quem he feu Senhor; quantas covas de Mandioca haó de plantar cada dia; quantas máos de Canna haó de cortar; quantas medidas de lenha hão de dar ; \& outras coufas pertencentes ao ferviço ordinario de feu Senhor: \& fabendo tambem pedirlhe perdaō, quando errâraó, \& encomendarfe-lhe, para que os naó ca. ftigue, com promettimento da emenda ; dizem os Senhores, que eftes naó faó capazes de aprender a confeffarfe, nem de pedir perdaó a Deos, nem de rezar pelas contas, nem de faber os dez Mandamentos: tudo por falta de enfino, \& por naó confiderarem a conta grande, que de tudo ifto haó de dara Deos; pois (como diz Saó Paulo) fendo Chriftáos, \& defcuidando-fe dos feus Efcravos, fe haó com elles peyor, do que fe foffem Infieis. Nem os obrigaó os dias Santos a ouvir Miffa; antes tal vez os occupaó de forte, que naó tem lugar paraiffo: nem encomendaó ao Capellaó doutrinallos, dando-line por efte trabalho, fe for neceffario, mayor eftipendio.

O que pertence ao fultento, veltido,\& moderaçaô do trabalho; claro eftá, que fe lhes naó deve negar: porque a quem. o ferve deve o Senhor de juftiça dar fufficiente alimento ; mézinhas na doença ; \& modo, com que decentemente fe cubra , \& vifta, como pede o eftado de Servo, \& naó apparecendo quafí nú pelás ruas: $\&$ deve tambem moderar o ferviço de forte, que naófeja fuperior ás forças dos que trabalhaó, fe quer que 


\section{Cultura,}

que poffaó aturar. No Brafil coftumaó dizer, que para o Efcravo faó neceffarios tres PPP, a faber Pao, Paõ, \& Panno. E pofto que comecem mal, principiando pelo caftigo, que he o Pao; com tudo prouvêra a Deos que taó abundante foffe o comer, \& o veftir, como muitas vezes he o caftigo, dado por qualquer caufa pouco provada, ou levantada ; \& com in. ftrumentos de muito rigor, ainda quando os crimes faó certos: de que fe naó ufa nem com os Brutos animaes, fazendo. algum Senhor mais cafo de hum Cavallo, que de meya duzia de Efcravos: pois o Cavallo he fervido, \& tem quem lhe bufque capim; tem panno para ofuor; \& fella, \& freyo dourado.

Dos Efcravos novosfe ha de ter mayor cuidado; porque ainda naó tem modo de viver, como os que trataó de plantar fuas Roças: \& os que as tem por fua induftria, naó convem, que fejaớ fó reconhecidos por Efcravos na repartiçaó do trabalho; \& efquecidos na doença, \& na farda. Os Domingos, $\&$ dias fantos de Deos, elles os recebem : \& quando feu Senhor lhos tira, \& os obriga a trabalhar, como nos dias de fer-: viço, fe amofinaó, \& l he rogaó mil pragas. Coftumaó alguns: Senhores dar aos Efcravos hum dia em cada femana, para: plantarem para fi, mandando algumas vezes com elles o F ei-s tor, para que fe naó defcuidem: \& ifto ferve, para que naó, padeçaó fome, nem cerquem cada dia a cafa de feu Senhor, pedindo-lhe a raçaó de farinha. Porèm naó lhes dar farinha, nem dia para a plantarem ; \& querer, que firvaó de Sol a' Sol no Partido, de dia, \& de noyte com pouco defcanço no Engenho : como fe admittirá no Tribunal de Deos fem caftigo? Se o negar a efmola a quem com grave neceffidade a pede, he negalla a Chrifto Senhor noffo, como elle o diz no Euange1ho; que ferá negar o fuftento, \& o veftido ao feu Efcravo? E: que razaó dará de fi, quem dá ferafina, 3 r feda , \& outras galas ás que faó occafiaó da fua perdiçaós \& depois nega quatro: 


\section{Es Opulencia do Brafli.}

ou cinco varas de Algodaó, \& outras poucas de panno da Ser. $\mathrm{ra}$, a quem fe derrete em fuor para ofervir, \& apenas tem tem. po para bufcar húa raiz ; \& hum caranguejo para comer? E fe em cima difto o caftigo for frequente, \& exceflivo; ou fe irâó embora, fugindo para o Matto; ou fe mataráó per fí, como coftumaó; tomando a refpiraçaó, ou enforcando-fe ; ou pros curaráó tirar a vida aos que lha daố tam mà, recorrendo (fe for neceffario ) a artes diabolicas; ou clamaráó de tal forte a Deos , que os ouvirá, \& fará aos Senhores o que já fez aos E: gypcios, quando avexavaó com extraordinario trabalho aos Hebreos, mandando as pragas terriveis contra fuas fazendas, \& filhos, que fe lem na fagrada Efcritura: ou permittirá, que aflim como os Hebreos foraớlevados cativos para Babylonia em pena do duro cativeiro, que davaó aos feus. Efcra. vos; affim algum cruel inimigo leve effes Senhores para fuas Terras, para que nellas experimentem quam penofa he a vida, que elles deraố, \& daó continuamente aos feus Efcravos.

Naó caftigar os exceffos, que elles cómettem, feria culpa naó leve: porém eftes fe haóde averiguar antes, para naó caftigar innocentes: \& fe haó de ouvir os delatados; \& convenci dos, eaftigarfe-haố cóm açoutes moderados, ou com os meter em húa corrente de ferro por algum tempo, ou tronco. Caftigar com impeto, com animo vingativo, por maó propria, \& com inftrumentos terriveis, \& chegar tal vez aos pobres com fogo, ou lacre ardente, ou marcallos na cara, naó feria para fe fofrer entre Barbaros; muito menos entre Chri: ftáos Catholicos. O certo he, que fe o Senhor fe houver com os Efcravos como Pay, dando-lhes o neceffario para ofuiten. to, \& veftido, \& algum defcanço no trabalho; fe poderá tam. bèm depois haver como Senhor : \& naó eftranharàoó, fendó convencidos das culpas, q́ cómettèraó, de receberem có mí fericordia o jufto, \& merecido caftigo. E fe depois de errarem: como fracos, vierem per fi mefmos a pedir perdaó ao Senhor;

ouv 
ou bufcarem Padrinhos, que os acompanhem: em tal cafo he coftume no Brafil perdoarlhes. E bem he, que faibaó, que ifto lhes ha de valer : porque de outra forte, fugiráó por hía vez para algum Mocambo no Matto ; \& fe forem apanhados, poderá fer, que fe matem a fi mefinos, antes que o Senhor chegue a açoutallos; ou que algum feu Parente tome á fua conta a vingança, ou com feitiço, ou com veneno.

Negarlhes totalmente os feus folguedos, que faó o unico alivio do feu cativeiro, he querellos defconfolados, \& melancolicos, de pouca vida, \& faude. Por tanto naó lhes eftranhem os Senhores o crearem feus Reys, cantar, \& bailar por algumas horas honeftamente em alguns dias do anno, \& o alegraremfe innocentemente à tarde depois de terem feito pela maphãa fuas feftas de Noffa Senhora do Rofario, de Saó Benedito, \& do Orago da Capella do Engenho, fem gafto dos Efcravos; acudindo o Senhor com fua liberalidade aos Juizes, $\&$ dandolhes algum premio do feu continuado trabalho.Porque feos Juizes, \& Juizas da Fefta houverem §de gaftar do feu; ferá caufa de muitos inconvenientes, \& offenfas de Deos, por ferem poucos os que o podem licitamente ajuntar.

O que fe ha de evitar nosEngenhos, he o emborracharemfe com Garâpa azeda, ou Agua ardente; baftando concederThes a Garâpa doce, que lhes naó faz dano; \& com ella fazen feus refgates com os que a troco lhes daó farinha, feijoens, aipins, \& batatas.

Ver, que os Senhores tem cuidado de dar alguma coufa dos fobejos da mefa aos feus filhos pequenos, he caufa de que os Efcravos os firvaó de boa vontade, \& q́ fe alegrem de lhes multiplicar Servos, \& Servas. Pelo contrario algumas Efcrayas procuraó de propofito aborto, fó para que naó cheguem os fillhos de fuas entranhas a padecer o que ellas padecem. 


\section{G Opulencia do Brafl.}

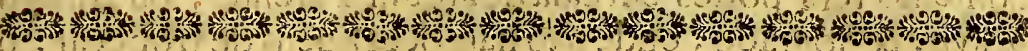

\section{A P I T U L O X.}

Como fe ba de baver o Senbor do Engentho no governu da fua Familia, Ẽ nos gaftos ondis. narios de caja.

D Edindo a fabrica do Engenho tantos, \& tam grandes gaftos, quantos acima diffemós ; bem fe vè a parfimonia, que he neceffaria nos particulares de cafa. Cavallos de refpeito mais dosque baftaó, Charameleiros, Trombeteiros, Tangedores, \& Lacayos mimofos, naó fervem para ajuntar fazenda, para diminuilla em pouco tempo com obriga çoens; \& empenhos. Emuitomenos ferven as Recreaçoens amiudadas; os Convites fuperfluos; as Galas; as Serpentinas, $\&$ o Jogo. E por efte caminho alguns em poucos annos do eftado de Senhores ricos chegáraó ao de pobres, \& arraftados Lavradores, fem terem que dar de dotés Filhas, nem mo. do para encaminhar honeftamente aos Filhos.

Mao he ter nome de Avarento: mas naó he gloria digna de louvor ofer Prodigo. Quem fe refolve a lidar com Engenho, ou fe ha-de retirar da Cidade, fugindo das occupaçoens da Republica, que obrigaó a divertir-fe; ; ou ha de ter actuals mente duas cafas abertas, com notavel prejuizo aonde quer que falte a fua afliftencia, \&ccom dobradadefpeza. Ter os Filhos fempre comfigono Engenho, he creallos Tabarêos, que nas converfaçoens naó faberáó fallar de outtra coufa mais que do Caó, do Cavallo, \& do Boy.Deixallos fós.na Cidade, he darlhes liberdade para fe fazerem logo viciofos, \& enche. rem-fe de vergonhofas doenças, quie fe naó podem facilmente curar. Paraevitar pois hum, \& outro extremo, o melhor: 
confelho ferà pollos em cafa de algum Parente, ou Amigo grave, \& honrado, onde nao haja occa fioens de tropeçar, o qual folgue de dar boa conta de $f_{1}^{4}, \&$ com toda a fidelidade avife dobom, ou mao procedimento, $\&$ do proveito, ou negligécia noEftudo. Nem confinta, q́ aMáy lhes remetta dinheiro,ou măde fecretaméte ordés para iffo ao feu Correfpó-

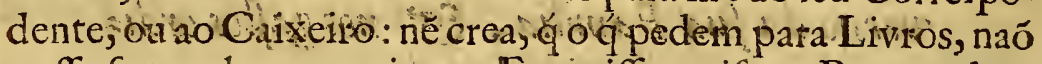
poffa fer tambem para jogos. E por iffo, avife ao Procurador, \& ao Mercador, de quem fe val, que lhes naó dé coufa alguma fem fua ordem. Porque para pedirem feràó muito ef peculativos, \& fáberàó excogitar razoés, \& pretextos verifineis; principalmenté fe forem dos que já andaô nó Curfo, \& tem vontade de levar tres annos de boa vida á cufta do Pay, ou do Tio, que naó fabem o que paffa ria Cidade, eftando nos feus Cannaveaes : \& quando fe jactaó nas converfaçoens de tcr hum Ariftoteles nos Pateos, póde fer que tenháóna Praça humAfinio, ou hum Apricio. Porém fe fe refolver a ter os $\mathrm{F}$ ithos em cafa, contentando-fe con que faibaóler, efcrever, \&z contar, \& ter álguma tal qual noticia de fucceffos, \& hiftorias, para tallarem entre gente; naó fe defcuide de vigiar fobre elles, quando a idade o pedir : porque tambem o campo largo he lugar de muita liberdade, \& póde dar abrolhos, \& efpinhos. E fe fe faz cercado aos Boys; \& aos Cavallos; para que naó vaó fóra do Pafto ; 'porque fe naō porátambem'algum limite aos Filhos, aflim dentro, como fóra de cafa ; moftrando a experiencia fer aflim neceffario ? Com tanto que a circunfpecçaó feja prudente; ; \& a demafia naó acrecente malicia. O nielhor enfinb porém, he o exemplo do bom procedimento dos Payts: \& o defcanço mais feguro, he dar a fer tempo eftado affim ás. Filhas, como aos Filhos : \& fefe contenturem com a igualdade, naoo faltaráó calas, ande fe poffaó fazer trocas', \& receberrecompenfas. 


\section{EOpulenciaido Brajl.}

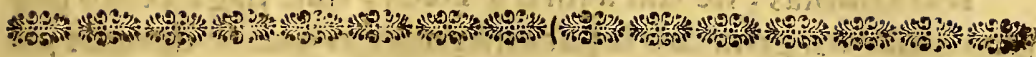

\section{A P I U U O XI.}

Como fe ba de bavero Senbor do Engenbo no recebie mento dos Hospedes, afsem Religiofos, como Seculares.

A. Hof pitálidade he hũa aç̧aó corteż; \& tăbem virtude: A Chriftaá, \& no Brafil muito exercitada, \& lovivada. porque faltando fóra da Cidade as Eftalagens, vaó necefEariamente os Paffageiros a dar comfigo nos Engentios, \& todos ordinariamente achaó de graça o que em outras Terras: cufta dinheiro: affin os Religiofos; qias bufcaó fuas efmolas, que naó fá poucos, \& os Mifilionarios, que vaó pelo Reconcavo, \& pela Terra dentro com grande proveito das Almas a exercitarfeus minifterios; como os Seculares, que ou por neceffidade, ou porconhecimento particular; ; ou por parentes: bufcaó de caminho agazalhó.

Tercafa feparada para os Hofpedes, he grande acerto: porque melhor fe recebem, \& com menor ettorvo da familia, \& fem prejuizo do recolhimento, que haó de guardar as Mulheres, \& as Filhas, \& as Moças de ferviço interior occupadtas no aparelho dojantar, \& 8 da cea.

O tratamento naó ha de exceder o eftado das Peffoas, que fe recebem; porq̆ no difcurfo do anno faó muitas. A creaçaó miuda, ou alguns peixes do Mar, ou Rio vizinho, com algú marif́co dos Mangues; \&o q́ dà o mefmo Engenho para doce; bafta, para que ninguem fe poffa queixar com razaó. Avançar-fe a mais (falvo em hum cafo particular por juftos. refpeitos) he paffar os limites, \& impoffibilitar-fe a poder continuar igualmente pelo tempo futuro. 


\section{Cultura,}

Dar efmolas, he dar a juro a Deos, que paga cento por hum : mas em primeiro lugar eftá pagar o que fe deve de juftiça ; \& depois eftender-le piamente ás efmolas conforme o cabedal, \& o rendimento dos annos. E nefta parte nunca fe arrependerá o Senhor de Engenho de fer efmoler; \& aprenderáó os Filhos a imitar ao Pay! \& deyxando-os inclinados ás obras de mifericordia, os deixará muito ricos; \& com riquezas feguras.

Para os vadios, tenha enxadas, \& fouces : \& fe fequizerem deter no engenho, mande-thes dizer pélo Feitor, que trabalhando, lhes pagaráó feu jornal. E defta forte ou feguiráó feu caminho ; ou de vadios fe faráó jornaleiros.

Tambem naố convèm que o Meftre do Affucar, o Caixeiro, \& os F eitores tenhaó em fuas cafas por tempo notavel Peffoas da Cidade, ou de outras partes, que vem a paffar tempoociofamente : \& muito mais, fe forem folteiros, \& moços; porque eftes naó fervem fenaó para eftorvar aos mefmos Officiaes, que haó de attender ao que lhes pertence ; \& para defenquietar as Efcravas do Engenho, que facilmente fe deixaó levar do feu pouco modérado appetite a obrar mal. Eifto fe lhes deve intimar ao principio; para que naó accarretem atraz de fi fobrinhos, ou Primos, que com feus vicios lhes dem pezados defgoftos.

- Os Miflionarios, que defintereffadamente vaó fazer feir officio, devem fer recebidos com toda a boa vontade; paraque vendo efquivanças naó venhaó a entender, que o Senhor doEngenho, por pouco affeiçoado ás coufas de Deos, ou por mefquinho, ou por outro qualquer refpeito, naó folga com a Mif̣aó, em. a qual fe ajuftaó as confciencias com Deos, fe dá inftrucçaó aos ignorantes, fe ataihaó inimizades, \& occafioens eficandalofas de annos, \& fe procura, que todos tratem da falyaçaó de fuas Almas. 


\section{\&Opulencia do Brafl!}

*4.

\section{A P I T U I O XII.}

Como se ba de baver o Senbor do Engenho com os Mercadores, E于 outros Jeus Correfponden. tes na Praça: Eo de alguns modos de ven. der, E comprar o Afjucar, conforme o eftylo do Brafil.

Credito de hum Senhor de Engenho funda-fe na fua verdáde, ifto he, na pontualidade, \& fidelidade em guardar as promeffas. E affim como o haó de experimentar fiel os Lavradores nos dias, que fe thes devem dar para moer a fua Canna, \& na repartiçaó do Affucar, que lhes cabe; os Officiaes na paga das foldadas; os que daó a lenha para. as Fornalhas, Madeira para a Moenda, Tijolo, \& Formas para a Cafa de purgar, Taboas para encaixar, Boys, '\& Cavallos para a Fabrica : affim tambem fe hade acreditar com os Mercadores, \& Correfpondentes na Praça, que lhe deraó dinheyro, para comprar Peças, Cobre, Ferro, Aço, Enxarcias , Breo, Velas; \& outras fazendas.fiadas. Porque fe ao tempo da Frota naô pagarem o que devem; naó teráó com que fe aparelhem para a fafra vindoura; nem fe achará quem queira dar o feu dinheiro ou fazenda nas mãos de quem lha Haō ha de pagar, ou tam tarde, \& com tanta difficuldade, que fe arrifque a quebrar.

Ha annos, em que pela muita mortandade dos Efcravos, Cavallos, Egoas, \& Boys, ou pelo pouco rendimento da Canna, naö podem os Senhores de Engenho chegar a dar a 
fatisfaçaó inteira do que promettèraô. Porém naô dando fe quer alguma parte, naó merecem alcançar as efperas, que pe. dem; principalmente quando fe fabe, que tiveraó para defperdiçar, \& parajogar, o que deviaó guardarparapagar aos feus Acredores.

Nos outros annos de rendimento fufficiente, \& com per das moderadas, oufem ellas, naó ha razaô para falta: aos Mercadores, ou Cónillariós, que negoceaó por feus Amos, aos quaes devem dar conta de fi.: \& por iffo naó he muito para fe eitranhar, fe experimentando faltar-fe por tanto tempoá palavra con lucro verdadeyramente ceffante, \& danno emergente, levantáo com jufta moderaçáo o preço da fazenda, que vendem fiada, \& que Deos fabe, quando poderàó miecadar.

Comprar anticipadamente o Affucar por dous cruzados, verbi gratia, que a feu tempo commummente val doze toftoens, \& mais, tem fua difficuldade : porque o comprador eftá feguro de ganhar; \& o vendedor he moralmente certo, que ha de perder: particularmente quando o que dá o. dinheiro anticipado, não o havia de empregar em outra cou. fa, antes do tempo de o embarcar para o Reyno.

Quem compra, ou vende anticipadamente pelo preço, que valerà o Affucar no tempo da Frota, faz contrato jufto; porque affim o comprador, como o vendedor, ẹtaó igualmente arrifcados: E ifto fe entende pelo mayor preço geral, que então o Affucar valer; \& não pelo preço particular, em que algum fe accommodar, obrigado da neceflidade a vendello.

Comprar a pagamentos, he dar logo de contadoalguma parte do preço, \& depois pagar por quarteis, ou tanto por cada anno; conforme o concerto, até fe inteirar de tudo. É poderá por-fe a pena de tantos cruzados mais, fe fe faltar a algum pagamento : masnáo fe poderá pertendẹ, que fe pague 


\section{\& Opulenciado $\mathrm{Brafl}$.}

gue juro dos juros vencidos; porque o juro, fó fe paga do principal.

Quem diz : Vendo o Afucar cativo : quer dizer : Ven do-o com obrigaçaó de o comprador pagar todas as cuiftas, tirando os tres toftoens, que fe pagaó na Bahia, porque eftes correm por conta de quém o carrega.

Vender o Affucar livie a dez toftoens, verbigratia, por cada arroba; quer dizer: Que o comprador ha de dar ao vendedor dez toftoens por cada arroba, \& ha de fazer todos os gaftos à fua cufta.

Quem comprou o Affucar cativo, \& o defpachou, o vende depois livre 3 \& o comprador faz os gaftos, $q$ qu elfe feguem.

Compraro Affucar por cabeças, quer dizer : Comprar as caixas de Afrucar pelo numero das arrobas "que tem na Marca, com meya arroba menos de quebra;

Quando fe péza húa caixa de Affucar, para pagar os direitos: fe $\delta$ Pezador péza favoravel, diz, verbi gratia, que a Caixa de trinta arrobas tem vinte \& oyto Eifto, El-Reyo fofre, \& confente de favor. Porém effa Caixa náóle vênde por efte pezo; mas pelo que na verdade; fe achar quando vay a pezar-fe na Balança fóra da Alfandega, que ahi eftás para fe tirar toda a duvida.

Vender as terras por menos do quevalem, com obriga: çaó de fe moer a Canna, que nellasfe plantar, no Engenhơ dovendedor; he contratolicito; \& jufto.

Comprar hum Senhor de Engenho a hum Lavrador, que tem Canna livre para a moer aonde quizer, a obrigaçaó de a moer no feu Engenho, em quanto lhe naó reftituir o dinhero, que para iffo lhe deo, quando comprou a dita obrigaçaó; pratica-fe no Brafil múitas vezes: \& os Letrados o defendẹm por contrato jufto : porque ifto naó he dar dinheiro empre, ftado com obrigaçaô de moer, mas he cónprair a obrigaçaó 


\section{Cultura,}

de moer no feu Engenho para ganhar a ametade do Affucar, ficando a porta aberta ao Lavrador para fe livrar defta obrigaçaó , todas as vezes que tornar a entregar ao comprador odinheiro, que recebeo.
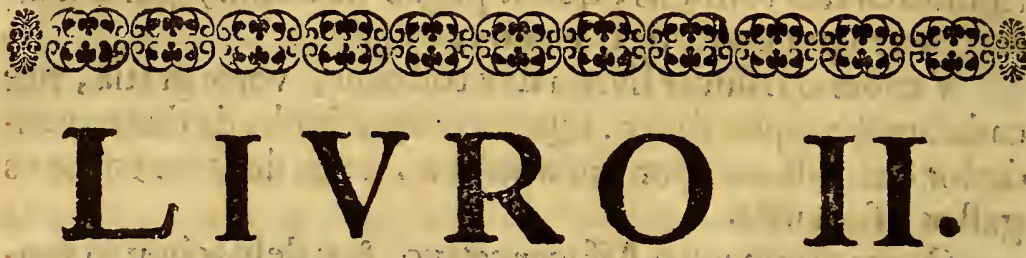

\section{A P I T V L O I.}

Da elcolba da Terra para plantar Cannas de eAjucar, E para os mantimentos neceSarios, o provimento do Engenbo.

A. S Terras boas, ou más, faó o fundamento principal, A para ter hum Engenho Real bom, ou mao rendi1. 1 mento. As que chamaó Maffapés, Terras negras, \& fortes, faó as mais excellentes para a planta das Cannas. Seguem-fe atraz deftas os Saloens, Terra vermelha, capaz de poucos córtes; porque logo enfraquece. As Areifcas, que faó hüa miftura de Area, \& Saloés, fervem para Mandioca, rz Legumes; mas naó para Cannás. E o mefmo digo das Terras brancas, que chamaó Terras de Area, , como fá as do Camanú, \& da Saubâra.

A Terra, que fe efcolhe para o Pafto ao redor do Engenho, ha de ter:agua : \& ha de fercercada, ou com plantas vivas, como faó as de Pinhioens; ou com eftacas, \& varas do inatto. Omelhor Pafto he o.que tem muita grama, parte cm

Outei- 


\section{\&O Oplencia do Brafl.}

Outeyro, sc parte em Varzea: porque defta forte em todoo tempo, ou em húa, ou em outra parte, afim os Boys, cómo as Beftas, acharáó que comer. O Pafto fe ha de confervar limpo de outras hervas; que mataó a grama : s no tem po do Inverno fe haó de botar fóra delle os Porcos, porque o deftroem folfando. Nelle ha de haver hum, ou dous Curraes, aonde fe metaó os Boys para comerem os ollios da Canna, \& para eftarem perto do ferviço dos carros. E tambem as Beftas fe recolhem no feu Curral, para as naó haver de bufcar efpalhadas.

Andaó no Pafto, alèm das, Egoas, \& Boys, Ovelhas, \& Cabras : \& ao redor do Engenho a criaçaó miuda, como fá Perús, Gallinhas, \& Patos, que faó o remedio mais prompto pára agazalharoshofpedes, que vem de improvifo. Mas porque as Ovelhas, \&ros Cavallos chegaó muito com o denteá raiz da grama, faó de prejuizo ao Paito dos Boys : \& por iffo fe o deftes foffe diverfo, feria melhor.

Os Mattos daó as Madeiras, \& a Lenha para as Fornathas. Os Mángues daó Caybros, \& Marifco. E os Apicủs (que faó as coroas, que faz o Mar entre fi, \& a Terra firme, \& as cobre a Maré) daó o barro, para purgar o Aflucar nas Fornas; \& para a Olaria, que na opiniaó de alguṇs fe naố efculanos Engenhos Reaes.

Detodas eftas cuftas de Terras tem neceflidade hum EngenhoReal; porque hưas fervem para Cannas, outras para mantimento da Gente, \& outras para o aparelho, \& provimento do Engenho, alèm do que fe procura do Reyno. Porèn nem todos os Engenhos podem ter efta dira : antes nenhum fe achará; a quem naó falte alguma deftas coufas. Porque aos que eftaó à beira-mar commummente faltaó as $R o$ ças, \& a Lenha : \& aos que eftáo pela Terra dentro faltaó ouj tras muitas conveniencins, que tem os quie eftaó à beira-nar no Reconcavo. Comtudo, de ter; ou naó tero Şenhor doy coig?

C. 3

En] 


\section{8 \\ Ciltura,}

Engenho cabedal, \& Gente, Feitores fieis, \& de experiencia., Boys, \& Beftas, Barcos, \& Carros ; depende o menear, \& governar bem, ou mal o feu Engenho, E fenaó tiver gente para trabalhar, \& beneficiar as terras a feu tempo; ferá o mefmo, que ter matto bravo com pouco, ou nenhum rendimento : aflim como naố bafta para a vida politica, ter bom natural; fe naó houver Meftre, que com o enfino trate de o perfeiçoarajudando-o.

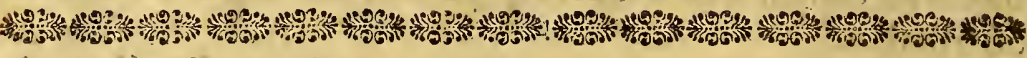
3

\section{A P I T U L O II. \\ Da planta, Eo limpas das Cannas: Es da diver. fidade, que ba nellas.}

$G$ Eita a efcolha da melhor Terra para a Canna; roça-fe, 14 queima-fe, $\&$ alimpa-fe, tirando-lhe tudo o que podia fervir de embaraço; \& logo abre-fe em regos, altos palmo \& meyo, \& largos dous, com feu camalhaô no meyo, para que nacendo a Canna naófe abafe : \& neftes regos ou fe plantaó ós olhos em pé, ou fe deitaó as Cannas em pedaços, tres,ou quatro palmos compridos: \& fe for Canna pequena, deita-fe tambem inteira, hũa junta á outra, ponta com pé: cobrem-fe com a terramoderadamente. E depois de poucos dias, brotando pelos olhos, começaó. pouco a. pouco a moftrar fua verdura á flor da terra,pegando facilmente, \& crecendo mais, ou menos, conforme a qualidade daterra, \& ofavor, ou contrariedade dos tempos. Mas fe forem muito juntas, ou fe na limpa lhes chegarem muito a terra; naó poderào filhar, comó he bem.

A planta da Canna nos lugares altos da Bahia começa derde as primeiras aguas no fim de Eevereyro, ou nos princi- 


\section{\&Opulencia do Brafll.}

pios de Março, \& fe continûa atè ofini de Mayo: \& nas bait xas, \& V Varzeas (que faó mais frefcas, \& humidas) planta-fe tambem nos mezes de Julho, \& Agofto, \& por alguns dias de Setembro.Toda a Canna, q́ naó for fecča, ou viciada, nem de cannudos muitó péquenos, ferve para plantar. De fera Terra nova, \& forte, fegue-fe o crecer nella a Canna muito viçofa; \& a efta chamaó Canna brava: a qual a primeyra, \& fe, gunda vez, que fe corta, naó coftuma fazer bom Affucar: porfer muitoaguacenta: Porèm dahi por diante, depois de. esbravejar a Terra, ainda que creça extraordinariamente, he tam boa no rendimento, como fermofa na apparencia : \& de-ftas ás vezes fe achaó algumas altas lete,oito, \& nove palmos; \& tam bem poftas no Cannaveal, como os Capitaens nos ex ercitos.

A melhor Canna he a de cannudo comprido, \& limpo; \& as que tem cannudos pequenos, \& barbados, fá as peyo res. Nace o terem cannudos pequenos, ou da feca, ou do frio: porque húa, \& outra coufa as apertaó : \& o terem barbas pro. cede de lhes faltarem com alguma limpa a feu tempo. Começa-fe a alimpar a Canna, tanto que tiver monda, ou herva de tirar. Nolnverno a herva, que fe tira, torna logoa nacer, 8 . as limpas mais neceffarias faó aquellas primeiras, que fe fazem, para que a Canna poffa crecer, \& o capim a naó afogue: porque depois de crecida, vence melhor as hervas menores. E aflim temos, que os primeiros vicios faó os que botaó. a perder hum bom natural. As Cannas, que fe plantaó nos ou: teiros, faó ordinariamente mais limpas, que as que fe plantaó nas Varzeas : porque affim como o correr a agua do Outeiro, he caufa que fe naó criem nelle tam facilmente outras hervas; a flim o ajuntar-fe ella na Varzea, he caufa de fer efta fempre muito humida, \& confeguintemente muito difpolta para crear de novo o capim.

Por iffo em hūas Terras ásvezes naó baftaó tres limpas; $=\ldots$

$$
\text { C } 4
$$

$\& \mathrm{~cm}$ 


\section{0 \\ Cultura,}

\& en outra o Lavrador com a fegunda defcança, conforme os tenipos mais ou menos chuvofos. Aflim como ha filhos tam dóceis, que com a primeira amoeftaçaó fe emendaó ; \& para outros náo baftaó repetidos caftigos.

As Socas tambem (que faó as raizes das Cannas cortadas a feu tépo, ou queimadas por velhas, ou por cahidas de forte, que fe naó poffaó cortar, ou por defaftre) fervem para planta: : porque fe naó morrerem pelo muito frio, ou pela muita feca; chegandolhes a terra, tornaó a brotar, \& podem defta forte renovar ao Cannaveal por cinco ou feis annos, \& mais. Tanto vala induftria, para tirar proveito, ainda do que pareceria inutil, \& fe deixaria por perdido. Verdade he, que cançandoa Terra, perdc tambem a Soca o vigor ; \& depois de feis ou fete annos a Canna fe acanha, \& facilmente fe mur. cha, atè ficar fecca, \& ażoutgada. E por iffo naó fe ha de pertender da Terra, nem da Soca mais do que póde dar, particularmente fenaó for ajudada com algum beneficio : \& a advertencia dobom Lavrador confifte em plantar de tal forte fucceffivamente a Canna, que cortando-fe a velha para a moenda, fique a nova em pé para a fafra vindoura; \& defta. forte alimente com a fua verdura a efperança do rendimento, que fe prepara, que he o premio do feu continuado trabalho. Plantar huia tarefa de Cannas, he o melmo que plantar no efpaço de trinta braças de terra em quadra. Finalmente porque a diverídade das T erras, $\&$ dos Climas pede diverfa cultura; he neceffario informar-fe, \& feguir o confelho dos vethos, aos quaes enfinou muito o tempo, \& a experiencia ; perguntando em tudo o que fe duvidar, para obrar comaccrto.

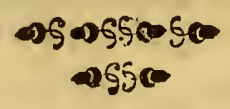

C A. 


\section{\& Opulencia do Brajl.}

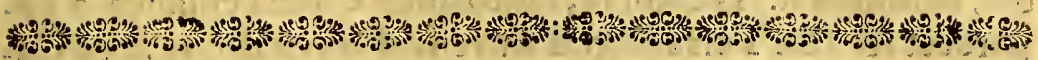

\section{A P I U U O III.}

\section{Dos inimigos da Canna, em quanto eftà no Cans naveal.}

$\triangle$ S inclemencias do Ceo faố o principal inimigo, que A tem as Cannas; aflim como os outros frutos, \& novidades da Terra: querendo Deos com muita razaó ; que féarmem contra nós os Elementos por caftigo das noffas culpas: ou para exercicio da paciencia, ou para que nos lembremos, que elle he o Author, \& o Confervador de todas as coufas, \& a elle recorramos em femelhantes apertos.

Os Cannaveaes nos Outeiros refiftem mais ás chuvas; qua ndo faó demafiadas; porèm faó os primeiros a queixar-fe da fecca.Pelo contrario as Varzeas naó fentem tam depreffa a força do exceffivo calor; mas na abundancia das aguas choraó primeiro fuas perdas. A Canna da Bahia quer agua nos mezes de Outubro, Novembrò, \& Dezembro ; \& para a planta nova em Fevereiro : \& quer tambem fucceffivamente Sol, o qual commummente naó falta ; afîm naó faltafem nos fobreditos mezes as chuvas. Porém o inimigo mais molefto \& mais continuo, \& domeftico da Canna, he o capim; pois mais, ou menos, até o fim a perfegue. E por iffo tendo o plantar, \& o cortar feus tempos certos; o alim par obriga aos Efcravos dos Lavradores a irem fempre com a enxada na maó: \& acabada qualquer outra occupaçaó fóra do Canna.veal, nunca fe mandaó de baldế a alimpar. Exercicio, quo deveria fer tambem continuo nos que trataó da boa creaçaó. dos filhos, \& da cultura do Animo. Eainda que fó efte inimigo bafte por muitos; naó faltaó outros de naó menor enfa*

do, 
do, \& moleftia. As Cabras, tanto que a Canna começa a apparecer fóra da Terra, logo a vaó enveftir: os Boys, \& os Cavallos ao principio lhe comem os olhos, \& de pois a de rrubaó, \& a pizaó: os Ratos, \& os Porcos a roem: os Ladroens a furtaó a feixes; nem paffa Rapaz, ou Caminhante, que fenaó queira fartar, \& defenfadar á cuifta de quem a plantou. E pofto que os Lavradores fe accommodem de qualquer modo a fofrer os furtos pequenos dos frutos do feu fuor; vẽfe ás vezes obrigados de hũa jufta dor a natar Porcos, Cabras; \& Boys, que outros naó trataớ de divertir; \& guardar nos paftos cercados, ou em parte mais remota ainda depois de rogados, \& avifados que ponhaó cobro a eftedano: donde fe feguem queixas, inimizades, \& odios, quefe remataó com mortes, ou com fanguinolentis, \& afrontofas vinganças. Por iffo cada qual trate de cefender os feus Cannaveaes, \& de evitar oc'; cafioens de outros fe quieixarem juftamente do feu muito defcuido, medindo os danos alheyos com o fentimento dos proprios.

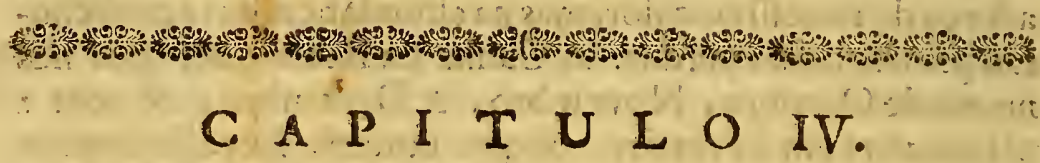

Do córte da Cama, Eo jua conducçaö para $\cdot$ o Engenbo.

Omeçando Engenho a moer (o que no Reconcavo da Bahia coltuma ter feu principio em Agofto) conseça também o tempo de meter a foucena Canna, que diffo lie capaz: \& para bem, antes de fe cortar, ha de eftar dezafete, ou dezoito mezes na Terra : \& dalii por diante, fe a muita fecca a naó apertar, póde feguramente eftar na micfma Terra outros fere., ou oito mezes. Tanto pois que eniverde rez, 


\section{Eo Opulencia do Brafil.}

fe mandará pôr nella a fouce, tendo jà certó o dia, em que fe ha de moer ; para que naô fique depois de cortad a murchar fe no.Engenho; ou fe naó feque expofta ao Sol no porto; fe efte for diftante da Moenda preferindo o Lavrador, que avifado trouxe primeiro a Canna para o Engenho, até fe acabar inteiramenteafua Tarefa ; $<$ perdendio ovagarofo o lugar quelihe cabia, fe porfeu defcuido deixoù paffar o diafina. lado. E o Senhor do Engenho he o que reparte os dias, afim para moer a fua Canna, como a dos Lavradores, conforme cabe a cada qual poi feu turno; \& manda o avifo pelo F eitos a feut tempo.

Quándo fe corta a Canna, fe metem doze até dezoito fouces no Cannaveal, conforme for a Caniagrande, oul pequena. E a que fe manda a moer de húa vez chama-fe húa Tarefa; que vem a fer vinte \& quatro carros de Carina, tendo: cada carroajufta medida de oyto palmos de alto, \& Tete de largo, capaz de mais ou menos feixes de Canin, y conforme ella for grande, ou pequena: porque menos feixes de Canna grande baftaó para fazera Tarefa; ; \& mais haó de fer neceffa, rios, fe for Canna pequena; pois a pequena occupa merior lugar afím no carro, como no barco : \& a grande occupa em húa, \& outra parte mayor efpaço, pelo que tem de mayor - comprimento, \& groffura Raro porém ferà o carro, que traga mais de cento \&r cincoenta feixes de Canna : \& os $\mathrm{Se}$ nhores dos.Partidos, pelos córtes antecedentes fabem muito bem, quantas Tarefas tem nos feus Cannaveaes.

A primeira Canna, que fe ha de cortar, he a velha, que naó póde efperar: coftume, que naó guarda a Morte, cuja fouce corta indifferentemente moços, \& velhos: E efta cor te-fe a tempo, quefe naó faça prejuizo á Soca , conforme as Terras, mais ou menos frias, \& os diás de mayor ou menor calor, \& fem chuwa. E difto procede náó fe poder cortar a Cannaem huias Terias depois do fim de Feyereiro; $8 \mathrm{em}$ our 
tras cortar-fo ainda em Marce, \& Abril. Quanto ao córte da Canna nova: fe o Lavrador for muito ambiciofo, $\&$ defejo: fodefazer muito Affúcar, cortará tudo em hứa fafra, \& acharfe-ha com pouco, ou nada na outra. Por iffo o córte da nova ha de ter fua conta; \& fe ha de attentar a o futuro, conforme o que fe tem plantado, afando de huma repartiçaó confiderada, \& fegura: que he o que dicta em qualquer outra obracu negocio a boa economia, \& prudencia.

Alnim os Efcravos, como as Efcravas fe occupaó no córte da Canna: porém commummente os Efcravos cortaó, \& as Efcravas amarraó os feixes. Confta o feixe de doze Cannas: \& tem porobrigaçaố cada Ef cravo cortar em hum dia fete niãos de dez feixes por cada dedo, que faó trezentos \& cincoenta feixes; \& a Efcrava ha de amarrar outros tantos có os olhos da mefma Canna : \& fe lhes fobejar tempo, ferá para o gaftarem liviemente noque quizerem. $O$ que ná fe concede na limpa da Canna; cujo trabalho começa defde o Sol nacido atè o Sol pofto: comotambem en qualquer outra oc: cipaçaó, quefe náódá por Tarefa: Eo contara Tarefa do corte, como eftá dito, por máos, \& dedos, he para fe accom: modar á rudeza dos Efcravos boçaes ; que de outra fcrte naó ențendem, "nem fabem contar.

or O modo de cortar he o feguinte: péga-fe com a máo ef- . querdarentantas Cannas, quantas póde abarcar; \& con a direita armada de fouce fe lhe tira a palha, a qual depois fe queima ou pela madrugada, ou já de noite, quando acalman: do o vento der para iffo lugar; \& ferve para fazer a Terra mais fertil :logo levantando mais acima a maó efquerda, botaö-fe fóra com a fồceos ollos da Canna; \& eftes daó-fe aós Boys a comer : \& ultimamente tornando com a efquerda mais abairo, corta-ferénte ao pé; \& quanto a fouce for mais rafteira á terra, melhor. Quem fegue ao que certa (que com: nummeatehe huta Efcrava) ajunta as Cannas limpas, como $\varepsilon . .8$ 


\section{¿o Opulencia do Brafl.}

eftá dito, em feixes, a doze por feixe, \& com os olhos dellas os vay atando : \& aflim atados vaó nos carros ao porto; ou, fe o Engenho for pela Terra dentro , chega o carro á Moenda.

A conducçaó da Canna por terra faz-fe nos carros: \& para bé cada fazenda ha de ter dous; \& fe for grande, ainda mais. Por mar vem nas barcas fem vela, com quatro varas, que fervé em lugar de remos nas mãos de outros tantos Negros $\mathrm{Ma}$ rinheiros, \& o Arraes, que vay ao leme: \& para iffo ha mifter duas barcas capazes, como as que chamáo Rodeiras. O Lavrador tem obrigaçaố de cortara Canna, \& de a conduzirá fua culta até o porto, aonde o barco do Senhor do Engenho a recebe, \& leva de graça até a Moenda por mar; pondo-a no dito barco os Efcravos do Lavrador , \& arrumando-a no barco os Marinheiros. Mas fe for Engenho pela terra dentro; toda a conducçaó por terra atè a Mónda corre por conta do dono da Canna, quer feja livremente dada, quer obrigada ao. Engenho.

Conduzir a Canna por terra em tempo de chuvas, \& la mas, he querer matar muitos Boys, particularmente fe vieraô de outra parte magros, \& fracos, eftranhando o pafto novo, \& o trabalho. O que muito mais fe ha de advertir na conducçaó das Caixas, como fe dirá em feu lugar. Por iffo os Boys, que vem do Certaó cançados, \& maleratados no caminho, para bem nāo fe hão de pôr no carro, fenaó depois de eftarem pelo menos anno \& meyo no pafto novo, \& defe acoftumarem pouco a pouco ao trabalho mais leve, começando pelotempo do Verăo, \& não no do Inverno: de oultra forte, fuccederá ver o que fe vio em hum deftes annos paffados, em que morrèrăo fó em hum Engenho duzentos, \& onze Boys, parte nas lamas, partena Moenda, \& parte no Pafto. Efe moendo con agua, \& ufando de barcos para a conducçaō da Canna, he neceffario ter no Engenho quatro ou cin- 


\section{Cultura,}

ou cinco carros, com doze, ou quatorze juntas de Boys muito fortes; quantos haverá mifter quem moe com Beftas, \& Boys, \& tem Canna propria , para fe conduzir de longe á Moenda? Advirta-fe muito nifto, para fe comprarem a tempo os Boys, \& taes, quaes faó neceffarios: dando antes oito mil reis por hum fô Boy manfo, \& redondo, do que outro tanto por dous pequenos, \& magros, que naó tem forças para aturarem no trabalho.

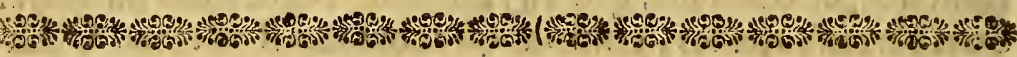

\section{A P I T U L O V.}

\section{Do Engenbo, ou Casa de moer a Canna: $\sigma^{\circ}$ como semove a Moenda com agma.}

A Inda que o nome de Engenho comprehenda todo 0 A Edificio, com as Officinas, \&x cafas neccliarias para moer a Canna, cozer, \& purgar o Af́ucar ; com tudo tomado mais em particular, omefmo he dizer Cafa do Engenho; que Cafa de moer a Canna com o artificio, que engenhoramente inventâraó. E tendo nós já chegado a efta Cała com a Canna conduzida para a Moenda, daremos alguma noticia do que ella he, \& do que nella fe obra, para efpremer o Afiucar da Canna; valendo-me do que vi no Engenho Real de Serigippe do Conde, que entre todos os da $\mathrm{Bahia}$ he o mais aframado.

Levanta-féa borda do Rio fobre dezafete grandes pila: res de tijolo, largos quatro palmos, altos vinte \& dous, \& diftantes hum de outro quinze, hüa alta, \& efpaçofa Cafa, cujo tedto cuberto de telha affenta fobre tirantes, frechaes, \&t vigas de paós, que chamăo de ley, que faố dos mais fortés, que ha no Brafil, a quem nenhüa outra Terra leva netta pato 


\section{\&o Opulencia do Brafl.}

te ventagem; com duas varandas ao redor : húa para receber Canna, \& lenha; outra para guardar madeiras ufuaes de fobrecellente. E a efta chamaó Cafa da Moenda, capaz de receber commodamente quatro $T$ arefas de Canna, fem perturbaçăo, \&r embaraço dos que neceffariamente hāo de lidar na dita Cafa, \& dos que por ella paffaó, fendo caminho abers to para qualquer outra Officina, \& particularmente para as Cafas immediatamente contiguas das Fornalhas, \& das Cal deiras: contando de comprimento todo efte Edificio cento \& noventa \& tres palmos, \& oitenta \& feis de largo. Moe-fe ne fta Cafa a Canna com tal artificio de Eixos, \& Rodas, que bem merece particular reflexaó, \& mais diftinta noticia.

Tomaó para mover a Moenda do Rio acima, aonde faz a fua queda natural, a que chamaó Levada, que vem a fer húa por:çaố baftante de agua do açude, ou tanque, que para iffo tem, divertida com reprezas de pedra, \& tijolo, do feu curfo, \& levada com declinaçaó moderada por hum rego capaz ; \& forte nas margens, para que a agua vâu unida, \& melhor fe có. ferve, cobrädo na declinaçaó cada vez mayor impeto, \& for ça : com feu fangrador, para a divertir, fe for neceffurio, quando por razaó das chuvas ou cheas vieffe mais do que fe pertende; \& com outra.abertura para duas bicas, hüa que leva agua para a Cafa das Caldeiras, \& outra que vay a refrefcar o Aguilhaó da Roda grande dentro da'Moenda ; fervindo-fe, para a communicar ao outro Aguilhaó, de hüa taboa : \& af: fim vay a entrar no cano de pao, que chamăo Caliz, fuften. tado de pilares de tijolo, \& na parte fuperior defcuberto, $\mathrm{cu}$ jo extremo inclinado fobre os cubos da Roda fe chama. Feridor ; porque por elle vay a agua a ferir os ditos Cubos, donde fe origina, \& continùa o feu moto. Affentão is Aguilhoés do Eixodefta Roda, him pela partedefóra, \& outropela. parte de dentro da Cafa da Moenda, fobre feus chumaceiros de pao, com chapa de bronze; \& a eftes.fuftentaó diass:Vir. $\operatorname{gen} \delta_{j}$; 


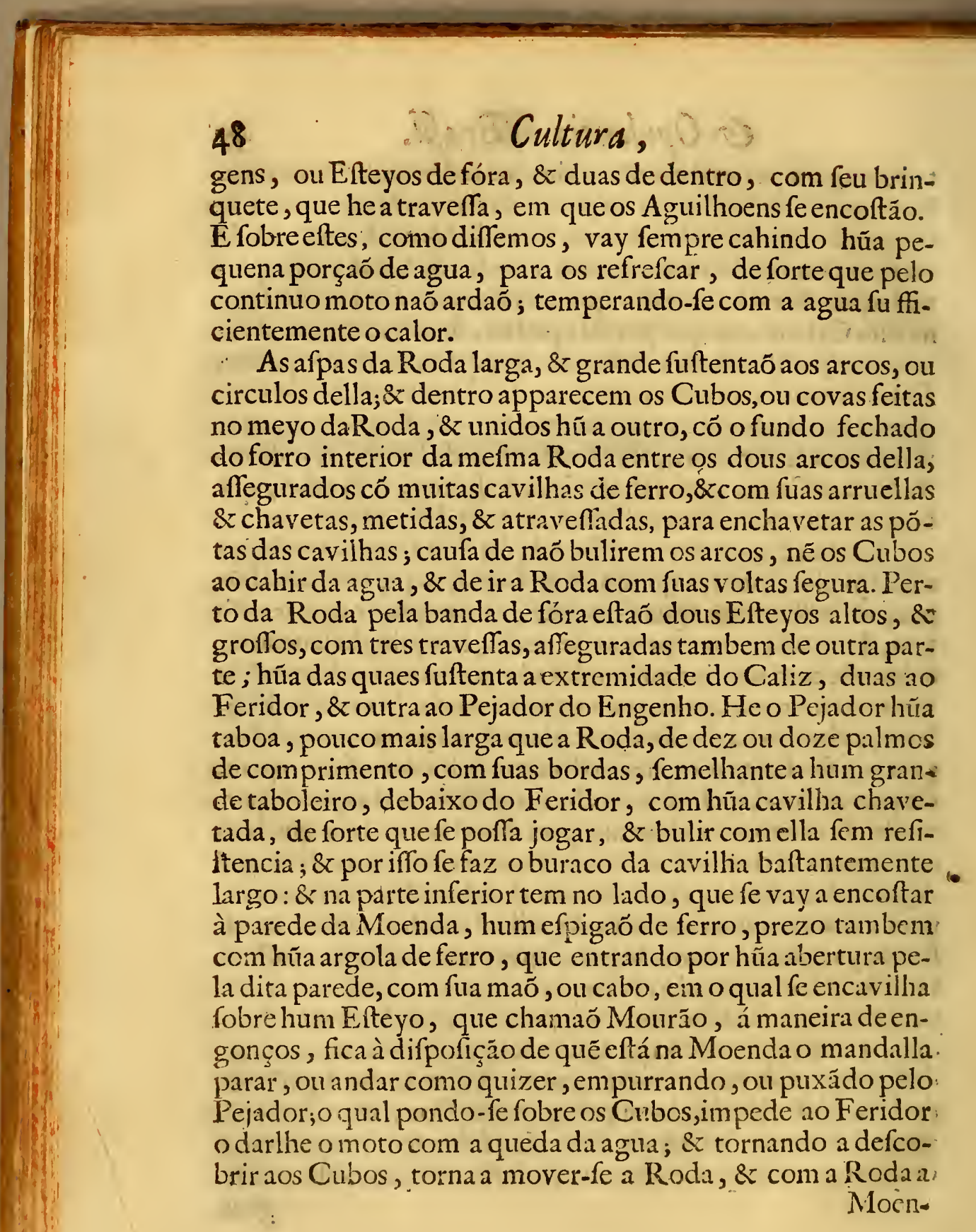




\section{\&Opulencia do Brafil.}

Moenda. E ifto he muiro neceffario em qualquer défaftre, que póde acontecer; para the acudir depreffa, \& atalhar os perigos. E chamão a efta taboa Pejador; porque tambem ao pa rar doEngenho chamáo pejar:por vêtura, porfe pejar hum Engenho Real de fer retardado', ou impedido, ainda por hum inftante; $\&$ de não fer fempre, como he razáo, moente, \& corrente. E ifto quantoá parte exterior da Mcenda, donde principia ofeu movimento.

Entrando pois na Cafa interior; o modo com que fe communica o móto por fuas partes á Moenda, he ofeguinte. $O$ Eixo da Roda grande, que, como temos dito, pela parte de fóra fe metedentro da Cafa do Engenho, tem no feu remate interior, chegado aonde affenta o Aguilhão fobre o brinquete, \& Efteyos, hum Rodete fixo, \& armado de dentes, que o cerca; \& efte virado ao redor pelo caminho do dito Eixo, apanha fuccellivamente na volta, que dá comfeus dentes, outros de outra Roda fuperior, tambem grande, que cha: máo Volándeira, porque o feu modo de andar circularmente no ar Fobre aMoenda fe parece com o voar de hum paffaro, quando dá no ar feus rodeos. Os dentes do Rodete, que eu vi, erão trinta \& dous; \& os da Volandeira, cento \& doze. E porque ás afpas da Volandeira paffăo pelo pefcoço do Eixo grande da Moenda; por ellas fe lhe cómunica o impulfo : \& efte recebido do dito Eixo grande, cercado de entrozas, \& dentes, fe communica tambem a dous outros Eixos menores; que tem de ambas as ilhargas, dentados, \& abertos igualmente, com fuas entrozas do mefmo modo, que temos dito do grande: \& com eftes dentes, \& entrozas fé caufa o moto; com que uniformenente $o$ acompanhão.

As a?pas da Volandeira faó oito, quatro fuperiores, \& quatro inferiores : \& as inferiores tem fuas contrafpas, para mayor fegurança. Os tres Eixos da Moenda făo tres paos redondos de corpo esferico, alto nos menores iguaes cinco pal,

D mis 


\section{Cultura,}

mos \& meyo; \& no mayor, que he o do neyo, alto feis palmos, \& tambem de esfera mayor que os outros, \& por eleiçaó o melhor; porque jogando com os dous, que nasilhargas continuamente o apertáo, gafta-fe mais que os outros: \& poriffo por boa regra os menores tem nove dentes, \& o mayor onze; \& fó efte ( para fallarmos com a lingua dos $O f$ ficiaes) tem feu pefcoço, \& cabeça alta, conforme a altura do' Engenho, \& commummente ao todo vem a tero dito Eixo doze palmos de alto : cuja cabeça de dous palmos \& meyo, mais delgada que o pefcoço, entra porhum pao furado, que chamaó Porca, fuitentado de duas Vigas de quarenta \& $r$ dous palmos, as quaes affentaó fobre quatro Efteyos altos dezafete palmos, \& groffos quatro; com fuas traveffas proporcionadamente diftantes. E ainda que os outros dous Eixos menores naó tem pefcoço; com tudo pela parte de cima entraó quanto bafta, com fua ponta, ou aguilhaó, por huns paos furados, que chamáo Mezas, ou Gatos, ccm que ficaó direitos, \& feguros em pé. Os corpos dos tres Eixos, da ametade para baixo faó veftidos igualmente de chapas de ferro unidas, \& pregadas com pregos feitos para efte fim com a cabeça quadrada, \& bem entrante, para fe iguala. rem com as chapas: debaixo das quaes os corpos dos Eixos faó torneados com tornos de paos de ley, para que fique a madeira mais dura, \& mais capaz de refiftir ao concinuo aperto, que ha de padecer no moer. Sobre as chapas apparece hum circulo, ou faixa de pao, qu he a outra parte do corpo dos mefmos Exixos, defpida de ferro : \& logoimm ediatamente te legue o circulo dos dentes de pao de ley, encaixados no Eixo com fuas entrozas, (que faó húas cavaduras, ou vaós repartidos entre dente, \& dente) para entrarem, \& fahirem dellas os dentes dos outros Eixos collateraes; que para iflo faó cm tudo iguaes os dentes, \& $x$ as entrozas : a faber, os dentes na groffura; \& na altura; \& as entrozas nalarcrura, \& 


\section{Co Opulencia do Brajl.}

profundeza do encaixamento, ou vazió, que cómummente faem to corpo do Eixo, comprimento de cinco ou feis dedos, de largura de hũa maó, \& de quatro ou cinco dedos de cofta, de forma quafichata, \& nos extremos redonda. E ainda que entre dente', \& dente dos Eixos menores haja efpaço medido por compaffo de igual medida, que he hum palmo grande ; os do Eixo mayor tem de mais a mais tanto efpaço; alem do palmo, quanto occuparia a groffura de húa moeda de dous cruzados : $\&$ ifto fe faz, para que eftejaó em fua conta, \& naó entrem no mefmo tempo os dentes dos Eixos collateraes; mas hum fe figa atraz de outro, \& defta forte fecontinue em todos tres omoto, que fe pertende. E por iflo tambem os dentes, \& as entrozas de hum Eixo fe haó de defencontrar dos dentes, \& entrozas de outro: a faber, ao dente do Eixo grande ha de correfponder a entroz.a do pequeno; \& ao dente do pequeno a entroza do grande. Saó os dentes (como dizia) na parte que fae fóra do Eixo algum tanto chatos, \& no fim quafi redondos, largos quatro ou cinco dedos, \& outro tanto groffos: \& entraó quafi outros quatro dedos pela fua raiz no Eixo, aonde fe affeguraó, alem da parte, com qua. fazem parede às entrozas, que faó na mefna conta quatro ou. cincodedos profundas. Sobre os dentes dos Eixos menores. - fica a terceira parte do pao defcuberta, \& fe remata a modo de degraos em dous circulos menores, veftidos de duas argo. las de ferro de groffura de hum dedo \& meyo, largura de tres dedos: \& na ponta do pao fe vaza de tal forte, que entre nelle . húa buxa quadrada de dous ou tres palmos, de fapupira merím: a qual buxa tábem em parte fe vaza, \& nella fe encaixa o aguilhaó de ferro,cóprimento de tres palmos, grofiura de hũ caibro, á força de pancadas com hum vayvem de ferro. $\mathrm{E}$ para melhor fegurança do aguilhaó, \& da buxa, fe abre na cabeça dos quatro lados da buxa, com húa palmeta de ferro, á força de pancadas do vayvem; \& fe lhe metem húas palme-

$\mathrm{D}_{2}$

tas 


\section{2}

\section{Iin Culturá,}

tas, ou cunhas menores de pao de ley, para naó aluir. "E pelo mefmoeftylo de degraos, \& argolas, buxa, \& aguilhaō, com: que temos dito fe remata a parte fuperior dos dous Eixos me. nores, fe remataó tambem as partes inferiores de todos tres; ajuntando de mais a cada aguilhaó feu piaó de ferro, calçado de aço da groffura de hũa maçaá, que tambem fe encaixa pela parte fuperior até dous dedos dentro do aguilhaós; \& pela parte inferior poem a ponta fobre outro ferro chato, que chamaó mancal, de comprimento de hum palmo, tambem calçado de aço, para que fe naó fure com o continuo virar, que fobre elle faz o piaó. E todos eftes tres Eixos, ou corpos da Moenda, aonde chega o piaó ao mancal, affentaö fobre hum pao, que chamaó Ponte, de comprimento de quinze ou dezafeis palmos : \& para fuftentar toda a Moenda fore, \& fegura, fervem quatro Virgens, que faó quatro Efteyos, altos da terra nove palmos, \& groffos fete, femelhantes no feu officio de fufter aos que fuftentaó as Vigas grandes, \& a Pcrca, ou pao furado, por onde paffa a ponta do Eixo grande, que fobre os outros collateraes fe levanta atè a dita altura, como parte principal da Moenda. Sobre eftas Virgens de ponta a ponta vaó huns paos, que chamaó Mezas, quafi hum palmo de grofura, \& 2 vinte de comprimento, fobre as quaes defcancaóas traveffas, que chamaó Gatos, em que fe movem os Eixos pela parte fuperior: \& fobre eftes vay outro andar ao comprido, de taboas, que chamaó Agulhas, as quaes fervem para fegurar as cunhas, com que fe aperta a Moenda.

O lugar aonde fe poem os feixes da Canna, que immediatamente ha de paffar para fe efpremerentre os Eixos, fió dous taboleiros, hum de húa parte, \&r outro de outra, que tem feus encaixos, on meyos circulos ao redor dos Eixos da Moenda, afaftados deilles tanto, quanto bafta para naó lhes impedir fuas voltas. E o eftarem os taboleiros chegades aos Eixos, he para que naó caya a Canna,ou o baģaço della perta dos 


\section{EO Opulencia do Brafil.}

dos aguiilhoés, \& retarde de algum modo aos pioés; \& para que fe naó fuje o caldo, que fae da Canna moida.

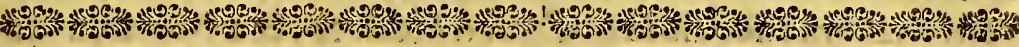

\section{A P I T U L O VI.}

Do modo de moer as Cannas: Eo de quantas peffoas necefita a Moenda.

$\mathbf{M}$ Oem-fe as Cannas, metendo algumas dellas limpas da palha, \& da lama (que para iffo, fe for neceffario, (e lavao ) entre dous Eixos : aonde apertadas fortemente fé efpremem, metendo-fe na volta, que daó os Eixos, os dentes da Moenda nas entrozas', para mais as apertar, \& efpremer entre os corpos dos Eixós chapeados, que vem a unirife nas voltas; \& depois dellas paffadas, torna-fe de outra parte a paffar o bagaço, para que fe efprema mais, \& dé todo o çumo; ou liquor, que conferva. E efte çumo (ao qual depois chamaś Caldo) cae da Moenda em hứa Cocha de pao, que eftá deitada debaixo da Ponte dos Aguilhoens; \& dahi corre por húa bica a hum Paról metido na terra, que chamaó - Paról do Caldo; donde fe guinda com dous caldeiroẽs, ou cubos para cima com roda, eixo, \& correntes, \& vay para outro Paról, que eftá em hum fobradinho alto, a quem cha: maô Guinda; para dahi paffar para $\mathbf{2}$ Cafa das Caldeiras,aonde fe ha de alimpar.

Noefpaço de vinte \& quatro horas moe-fe húa Tarefa redonda de vinte \& cinco até trinta carros de Canna ; \& em hīia femana das que chamaó folteiras (que vem a fer, fem dia: fanto ) chegaô a moer fete Tarefas: \& o rendimento competente he hũa formá, ou paó de Affucar por fouce; a faber, quanto corta hum Negro em hum dia. Nem o fazer mais Af $\mathrm{D}_{3}$ fucar 
54

\section{Cultura,}

fucar depende de moer mais Canna ; mas de fer a Canna de bom rendimento, a faber, bem affucarada, naó aguacenta, nem velha. Se meterem mais Canna, ou bagaço, do que côvem; haverá rifco de fe quebrar o Rodete, \& a Moenda dará de fi, \& rangerá na parte de cima, \& poderá fer , que fe quebre algum aguilhaó. Se a agua, que move a Roda, for muita, moerá tanta Canna, que naó fe lhe poderá dar vazàó na Cafa das Caldeiras, \& o Caldo azedará no Paról de coar, por fe naó poder cozer em tanta quátidadenem, taó depreffa nas Tachas. E por iffo o Feitor da Moenda, \& o Meftre do Affucar hão de ver o que convem ; para que fe naó percà a Tarefa.

Olugar de mayor perigo, que ha noEngenho, he o da Moenda : porque fe por defgraça a Efcrava, que mete a Canna entre os Eixos, ou por força do fono, ou por cançada, ou por qualquer outro defcuido, meteo defattentadamente a mão mais adiante do que devia ; arrifca-fe a paffar moida entre os Eixos; felhe naố cortarem logo a maó, ou obraçoapanhado, tendo para iffo junto da Mcenda hum facaó; ou naô forem taó ligeiros em fazer parar a Moenda, divertindo com o' Pejador a agua, que fere os cubos da Roda, de forte que dem depreffa a quem padece, de algum modoo remedio. $\mathrm{E}$ efte perigo he ainda may or no tempo da noite, em quefe moe igualmente comode dia ; pofto que fe revezem as que metem a Canna por fuas efquipaçoens : particularmete, fe as que andaó nefta occupaçaó forem boçaes, ou coftumadas a fe emborracharem.

As Efcravas, de que neceffita a Mioenda, no menos faó fete, ou oito: a faber, tres para trazer Canna ; hữa para a meter; outra para paffar o bagaço; outra para concertar, \& acender as candeas, que na Moenda faó cinco, \& para alimparo Cocho do Caldo (a queni chamáo Cocheira, ou Calumbá) \& os aguilhoés da Moenda, \& refrefcallos com agua, 


\section{EO Opulencia do Brajal.}

para que naó ardaó, fervindo-fe para iffo do Paról da agua, que tem debaixo do Rodete; tomada da que cae no AguiThaố; conotambem para lavar a Canna enlodada ; \& outra finalmente para botar fóra o bagaço, oú no Rio, ou na bagaceira, para fe queimar a feu tempo. E fe for neceflario botallo em parte mais diftante; naó baftará hũa fó Efcrava, mas haverà mifter outra, que a ajude : porque de outra forte naŏ fe daria vazáó a tempo , \& ficaria embaraçada a Moenda.

Sobre o Paról do Caldo, que, como temos diro, eftá metido na terra, ha húa Guindadeira, que continuamente guinda para cima com dous cubos o Caldo : \& todas as fobreditas Efcravas tem neceffidade de outras tantas, quêas revezem depois de encherem o feu tempo, que vem a fera. ametade do dia, \& a ametade da noite: $\&$ tcdas juntas lavão de vinte \&r quatro $\mathrm{em}$ vinte \& quatro horas com agua, \& vafculhos de piafla ba toda a Moenda. A tarefa das Guindadeiras he guindar cada hüa tres Paroes de Caldo, quando for têpo, para encher as Caldeiras; \& logooutra outros tres; fuccedendo defta forte hūa á outra, para que poffaó aturar no trabalho. E para obon governo da Moenda, alem do Feitor; que artende a tudo, nefte lugar mais que em outros, parte de dia, \& parte de noite, ha hum Guarda, ou Vigiador da Moenda : cujo officio he, attentar em lugar do Feitor, que a Canna fe meta, \& fe paffe bem entre os Eixos ; que fe defpeje, \&rtire o bagaço; que fe refrefquem, \& alimpem os Aguilhoens, \& a Ponte : $\&$ fuccedendo algum defaftre na Moen. da; elle he o que logo acode, \& manda parar:

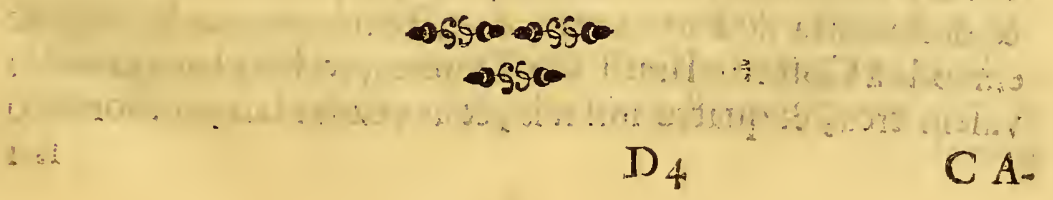




\section{6}

\section{Cultura,}

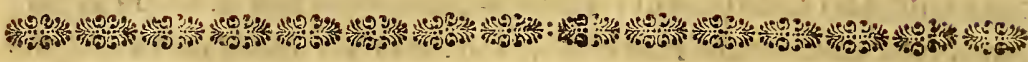

\section{A P I T U L O VII.}

Das Madeiras, de que fe faz a Moenda, Ej todo. o mais madeiramento do Engenbo, Canoas, E?: Barcos: Es do que se coftuma dar aos Carpinteiros, EG outros. Semelhantes Officiaes.

A Nes de paffar da Moenda para as Fornalhas, \& Cafa A dasCaldeiras; pareceme neceffario dar noticia dosPaos \& Madeiras, de que fe faz a Moenda, \& todo o mais madeiramento do Engenho, que no Brafil fe póde fazer com efcolha, por naó haver outra parte do Mundo tam rica de Paos felectos; \& fortes ; naố fe admittindo neita fabrica Pao, que naó feja de ley, porque a experiencia tem moftrado fer affim neceffario. Chamaố Paos de ley aos mais folidôs, de mayor dura ; \& mais aptos para ferem lavrados: \& taes faó os de Sapucâya, de Sapupîra, de Sapupîra carí, de Sapupîra merím, de Sapupîra açú, de Vinhatico, de Arco, de Jetay amarello, de Jetay preto, de Meffetaûba, de Maffarandûba, Pao Brafil , Jacarandá, Pao de Oleo, Picaí, \& outros femelhantes a eftes. O madeiramento da Cafa do Engenho, Cafa das Fornalhas, \& Cafa das Caldeiras, \& a de Purgar, para bem ha de fer de Maflarandûba ; porque he de muita dura, \& ferve para tudo, a faber, para Tirantes, Frechaes, Sobrefrechaes, Tifouras, ou Pernas de Afna, Efpigoěs, \& Terças : \& defta cafta de Pao ha em todoo Reconcavo da Bahia, \& em toda a Cofta do Brafil. Oș Tirantes, \& Frechaes grandes valem tres, \& quatro mil reis, \& ás vezes mais, conforme o feu 


\section{\& Opulencia do Brafil.}

feu comprimento, \& groffura, affim tofcos como vem do matto, tó com a primeira lavradura. Os Eixos da Moenda fe fazem de Sapucâya, ou de Sapupîra carí: a ponta,ou cabo do Eixo grande, de Pao de Arco, ou de Sapupîra: os dentes dos: tres Eixos da Moenda, do Rodete, \& da Volandeira faó de Meffetâuba. As Rodas da ağua, de Pao de Arco, ou de Sapupîra, ou de Vinhatico. Os Arcos do Rodete, \& Volandeira, ¿ as Afpas , \& Contrafpas, de Sapupîra. As Virgens, \& mais Efteyos, \& Vigas, de qualquer Pao de ley. Os Carros, de Sapupîra merím, ou de Jetay, ou de Sapucâya. A Caliz, de Vinhatico. As Canoas, de Picay, Joairâna, Jequitiba, Utufisica, \& Angelí. As cavernas, \& braços dos Barcos, de Sapupira, ou de Landim Carvalho, ou de Sapupîra merím: a quilha, de Sapupîra, ou de Parôba: os forros , \& coftados, de Utím, Parốba, Burayém, \& Unhuîba : os maftos, de Inhuibatin: as Vergas, de Camaffarí o leme, de Averno, ou Angelí: as curvas, \& as rodas da proa, \& poppa, de Sapupîra, com feus coraes metidos: as varas, de Mangue branco: \& os remos, de Lindirâna, ou de Genipappo.

As. Caixas, em que fe mete o Affucar, fe fazem de Jequitibà, \& Camafrarí : \& naō havendo deftas duas caltas de pao, quanto bafta; fe poderáó valer de Burifsîca para fundos, \& tampos. E eftas taboas para as Caixas vem da Serraria já ferradas, \& no Engenho fó fe levantaó, endireitaó, \& aparaó: \& haô de ter nos lados, para bem, dous palmos \& meyo de largo, \& fete \& meyo, ou oito de comprido : \& os fundos tres palmos de largo, \& o mefmo de comprimento. Valia húa Caixa nos annos paffados, dez, ou doze toftoens; agora fubîraó a mayor preço.

Hum Eixo da Moenda tof́co no matto, \& torado fó nas: pontas, ou ainda oitavado, val quarenta, cincoenta, \& feffenta mil reis, \& mais, conforme a qualidade do pao, \& aneceflidade, que ha delle. Os que vem de Porto-feguro, \& $\mathrm{Pa}$ tippe, 


\section{8}

\section{Cultura,}

tippe, faŏ fomenos, por ferem creados em Varzeas : os me. lhores faó os que vem da Pitanga, \& da Terra-nova acina de Santo Amaro. Toda a Moenda importa mais de mil cruzados; alem da Roda grande da agua, que por fer chea de cavilhas, \& cubos, val mais de duzentos mil reis.

Ao Carapina da Moenda fe daó cinco toftoés cada dia a feco: \& fe lhe derem de comer, dáfe-lhe hum cruzado, \& ainda mais neftes annos, em que todos os preços fubîraó. Quâí - mefmo fe dá aos Carapinas de obra branca. Aos Carapinas de Barcos, \& aos Calafates fe daó a feco fete toftoés \& meyo: \& feis toftoẽs, ou duas patacas, fe lhes derem de comer. Hum Barco velejado para carregar lenha, \& caixas, cuffa quinhentos mil reis : hum Barco para conduzir Canna, trezentos mil reis: \& húa Rodeira quatrocentos mil reis. As Canoas vendem-fe conforme a fua grandeza, \& qualidade do Pao. Por iffo fendo as de que cómummente fe ufa nos Engenhos, húas pequenas, \& outras mayores; mayor, ou menor tambem ferá o preçodellas, a faber, de vinte, trinta, quarenta, \& cincoenta mil reis.

Cortaó-fe os Paos no matto com machados no difcurfo de todo oanno, guardando as conjunçoés da Lua, a faber, tres dias antes da Lua nova, ou tres depois della chea : \& tirāo-fe do matto diverfamente; porć nas Varzeas hums cs vaó rolando fobre eftivas; outros os arraftá́ a poder de Efcravos, q̆ puxão: \& nos Outeiros, de alto a baixo fe decem com Socairo; \& para cima dos mefmos Outeiros, tambem fe arraftaó puxando. Ifto fe entende aonde naō ha lugar de ufar dos Boys, por fer a paragem ou muito a pique, ou muito funda, \& aberta en covoẽs. Mas aonde podem puxar os Boys, fe tiraá do matto com tiradeiras, amarrando com cordas, ou có fipòs, ou couros a tiradeira, fegurada bem com chavelha : \& na lama em tempo de chuva, dizem que te arraltaó melhor, que en tempo de feca; porque com a chuva mais facilmente efçorregaô. 


\section{\& Opulencia do Brafl.}

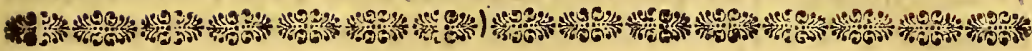

\section{A P I T U L O VIII.}

Da Caja das Fornalhas, feu aparelbo, E. Lenba; que ha mifter : Eั da Cinza, E゚ Jua Decoadia.

J Unto á Cafa da Moenda, que chamaó Cafa doEngenho, fegue-fe a Cafa das Fornalhas, bocas verdadeira. mente tragadoras de Mattos; Carcere de fogo, \& fumo perpetuo, \& viva imagen dos Vulcoés, Vefuvios, \& Etnas, \& quafi diffe do Purgatorio, ou do Inferno. Nem faltaó perto deftas Fornalhas feus condenados, que faó os Efcravos boubentos, \& os que tem corrimentos; obrigados a efta penofa affiftencia, para purgarem com fuor violento os humores Gallicos, de que tem cheyos feus corpos. Vem-fe ahi tábem outros Efcravos facinorofos, q̃ prezos em compridas, \& groflas correntes de ferro, pagaố nefte trabalhofo ex. ercicio os repetidos exceffos da fua extraordinaria maldade, com pouca, ou nenhúa efperança da emenda.

Nos Engenhos Reaes coftuma haver feis Fornalhas, \& nellas outros tantos Efcravos afliftentes, que chamaó Metedores da Lenha. As bocas das Fornalhas faó cercadas com arcos de ferro: naó fó para que fuftentem melhor os tijolos ; mas para que os Metedores no meter da lenha naó padeçaố a) gum defaftre. Tem cada Fornalha fobre a boca dous boeiros, que faó comoduas ventas, por onde o fogo resfolega. Os pilares, que felevantaó entre hứa, \& outra, hăo de fer muito fortes, de tijolo, \& cal: mas o corpo das Fornalhas fazfe de tijolo com barro, para refiftir melhor á vehemente aeit.

vidade 
vidade do fogo ; a qual naó refiftiria nem a cal, nem a pedra mais dura: \& as que fervem para as Caldeiras, faó algüa coufa mayores, que as que fervem para as $\mathrm{T}$ achas. $\mathrm{O}$ alimento do fogo he a lenha: " \& fó o Brafil com a immenfidade dos mattos, que tem, podia fartar, como fartou portantos annos, \& fartará nos tempos vindouros, a tantas Fornalhas, quantas faó as que fe contaó nos Engenhos da Bahia, Pernambuco, \& Rio de Janeiro, que commummente moem de dia, \& de noite, feis, fete, oito, \& nove mezes do anno. E para que fe veja, quam abundantes faó eftes Mattos; fó os de Jaguarippe baftaó para dar lenha a quantos Engenhos ha á beira-mar no.Reconcavo da Bahia : \& de facto quafi todos defta parte fô fé provém. Começa o cortar da lenha em Jaguarippe nos principios de Julho; porque na Bahia os Engenhos começaó a moer em Agofto.

Tem obrigaçaó cada Efcravo de cortar, \& arrumar cada dia húa medida de lenha, alta fete palmos, \& larga oito; \& efta he tambem a medida de hum carro : \& de oito carros confta a Tarefa. U cortar, carregar, arrumar, \& botara le: nha no Barco, pertence a quem a vende: o arrumalla no Bar: co, corre por conta dos Marinheiros. Ha Barcos capazes de. cinco Tarefas; ha de quatro; ha de tres : \& culta cadi Tarefa dous mil \& quinhentos reis, quando o Senhor do Engenho a manda bufcar com o feu Barco: \& fevier no Barco do vendedor, ajuntarfe-há de mais o frete, conforme a mayor, ou menor diftancia do Porto. Hum Engenho Real, que moe oito, ou nove mezes, gaftá hum anno por outro dous inil cruzados na lenha: \& houve anno, em que ongenho de Serigippe do Conde gaftou mais de tres mil cruzados, por moc: mais tempo, \& por cuftar a lenha mais caro. Vem a lenha em Barcos á vela, com quatro Marinheiros, \& o Arraes: \& para bem, o Senhor do Engenho ha de tér dous Barcos; para que em chegando hem, volte outro. Omelhor fortimentoda 


\section{\& Opulencia do Brafl.}

Lènlia he aquelle; cuja ametade confta de rolos 'grandes, \& traveços, que faŏ menores; \&r outra de lenha miuda : porque a grofla ferve para armar as Formaihas, \& para cozer o Afiucarnas $T$ achas, ande he neceffario mayor fogo ; para fe coalhar:a mediana ferve para fazer liga có a groffa : \& a miuda ferve para alimpar o Caldo da Canna nas Caldeiras ; porque para fe levantar bem a efcuma, demandaó continuamente lavaredas de chama. E por iffo a groffa fe chama Lenha de -Tachas; \& a miuda, Lenha de Caldeiras.

Chegada a Lenha ao Porto do Engenhó, arruma-fena fua bagaceira: \& fempre he bem, quediante, ou perto das Fornalhas eftejaó arrumadas cinco, ou feis Tarefas de Lenha. Gaftaó dous Barcos de Canna ordinariamente hum de Lenha, fe for Lenha fortida : porque fe for miuda, náo bafta. O primeiro aparelho da Lenha, para fe botar fogo á Fornalha, chama-fe armar: \& ifto vem a fer, empurrar Rolos, \& eftendellos no laftro, (o que fe faz com varas grandes, que chamaó Trasfogueiros ) \& fobre elles cruzar traveços, \& lenha miuda, para que levantada chegue mais facilmente com a chama aos fundos das Caldeiras, \& Tachas.: E o Metedor ha de eftar attento ao que lihe mandaố os Caldéireiros; botan. do precifamente a lenha, que os de cima conhecem, \& avifáó fer neceffaria : affim para que naó trasborde o Caldo, ou Melado dos Cobres ; como para que naó falte o ferver. Porque fe naó ferver em fua conta, naố fe poderá a limpar bem da im. mundicia, que ha de vir acima, para fe tirar, \& efcumar das Caldeiras. Porèm para as Tachas, quanto mais fogo, - melhor.

A Cinza das Fornalhas ferve para fazer Decoada : \& efta para alimpar ao Caldo da Canna nas Caldeiras, \& para q́ faya o Affucar mais forte. Para iffo, arrafta-fe com Rodode ferro atè a boca das. Fornalhas pouco a pouco a Cinza, \& borralho; \& dahicom húa páde ferrof fẹtra, \& feleva fobre a 
62)

\section{Cultura,}

mefma pá para o Cinzeiro, que he hum Tanque de tijoló fo: bre pilaresde pedra \& cal, de figura quadrada, com fuas paredes ao redor: \& aqui fe conferva quente, \& aflim quente fe poem nas tinas, que para iffo eftaó levantadas da terra fobre huns efteyos de tres palmos: Ahi, depois de bem caldeada, \& arrumada, fe lhe bota agua, tirada de hum tacho grande, que eftá fervendo fobre a fía proporcionada fornalha perto do Cinzeiro. E paraiffo ferve a agua, que paffa pela bica, que vayá Cafa das Caldeiras : \& coandoefta agua pela Cinza, até paffar pelos buiracos, que tem as tinas no fundo, cobra o nome de Decoada, \&r vay a cahir nas formas, ou vafil has enterradas atè a ametade; \& dahife tira com hum coco, \& fe paffa em hum tacho para a Cafa dasCaldeiras;aonde fe reparte pelas Formas ; que eftaó poftas entre as Caldeiras, \&r ferve para os Caldeireiros ajudarem com ella ao Caldo, como fe dirà em feu.lugar:

$\mathrm{Ha}$-fe porèm de advertir, que nem toda a lenha he boa, parafefazer Decoada : porque nem os paos fortes, nem a lenha fecca fervem para iffo. E a razaó he; porque os paos fortes fazem mais carvaó, do que cinza: \& a lenha miuda dà pouca cinza, \& fem força. A melhor he a dos Mangues brancos, \& de paos molles; a faber; a de Cajueiros, Aroeiras , \&o Gamelleiras. E para fe conhecer, fea Decoada he perfeita; ha-fe de provar, tocando a lingua com húa pinga della fobre a ponta do dedo: \&ł fe arder, ferà boa: fe naô arder, ferà fraca. Tambem, fe fobejar Cinza de hum anno para outro nas caixas, aonde a coftumaó guardar; antes de fe pôr nas tinas, deve tornar a aquentar-fe no Cinzeiro, ou mifturar-fe com a primeira, que fe tirar das Fornalhas com borralho: porque, ie antes enfraqueceo; com efte beneficio torna a cobrar feu vigor.

C A. 


\section{\&Opulencia do Brafl.}

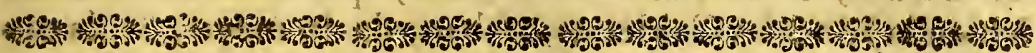

\section{A P I T U L O IX.}

Das Caldeiras, GO Cobres, Sen aparello, Oficiaes. E Gente, que nellas ba mister. E Inftrimentos de que usaũ.

A Terceira parte defte Edificio fuperior ás Fornalhas, he - a cafa dos Cóbres: porqueainda quite efta fe chame có. mummente a $\mathrm{Cafa}$ das Caldeiras, naơ faó ellas fó, que tem lugar nefta parte; mas outros grandes $V$ afos de cobre, como faô Paroes, Bacias, \& T Tachas: \& dentes Vafos tem os Engenhos Reaes dous ternos fempre em obra; porque de outra forte naó poderiaó dar vazàố ao Caldo, que vem da Moenda. Eftaó eftes Cobres poítos fobremabobada das Fornalhas em affentos, ou encoftadores de tijole, \& cal ao redor; abertos de tal forte, que com ofundo, que metem dentro da mefma Fornalha, tapa cada qual a abertura, em que fe recebe; 2x entra por ella proporcionadamente ao corpo, que tem ; a faber, menos as Tachas, \& muito mais as Caldeiras. E affim como tem fua parede, que divide húa de outra; \& outra pa rede, que divide efta Cafa da outra contigua do Engenho; aflim tem diante de fi hum, ou dous degraos, por onde fe fobe a obrar nelles com os inftrtumentos néceffarios nas inäos; \& com baftante efpaço, para dominár fobre elles com ajuftá. da altura, \& diftancia: \& ao redor de toda a parede dianteira, com caminho defafogado no meyo, eltáo Tendal das Formas, em que fe bota o Affucar já cozido a coalhar ; $8 x$ he capaz de oitenta, \& mais Formas.

$\therefore$ Confta hum terno', ou ordem de Cobres f alem do Paról 


\section{4}

\section{Cultura,}

do Caldo, \& do Paról da Guinda, que ficaó na Cafa da Moenda) de dilas Caldeiras, a faber, da do meyo, \& da oiitra de melar: de hum Paról da Efcuma : de hum Paról grande, que chamāo Paról do Melado; \&r de outro menor, que fe chama Parólde coar : de hum terno de Tachas, que faó quatro ; faber, a de receber, a da porta 'a de cozer, \& a de bater: \& finalmente de húa Bacia, que ferve para repart ir o Afucar nas Formás. E de outros tantos Cobres de igual, ott pouco menor grandeza, confta outro andar femelhante.

Leva o Paról do Caldo de hum Engenho Real vinte arrobas de cobre: o Paról da Guinda, ontras vinte arrobas : as duas Caldeiraś, feffenta arrobas : o Paról da Efcuma, doze arrobas : o Paról do Melado, quinze arrobas:o Paról de coar, oito arrobas: o terno das quatro Tachas, a nove arrobas cada húa, trinta \& feis arrobas: a Bacia, quatro arrobas: que $\mathrm{cm}$ tudo faó cento \& fetenta \& cinco arrobas de cobre : o qual vendendo:fe lavrado, quando he barato, a quatrocentos reis alivra, importa dous contos \& duzentos \& quarenta mil reis, que faô cinco mil \& feiscentos cruzados. E fe fe acrecentar outro terno de Cobres menores, ou iguaes, crecerá proporcionadamente o feu valor.

A parte,em q́ as Caldeiras, \& as Tachas mais padecé, heo fundo: \& fe efte for deruim cobre, \& naó tiver a groffura neceffaria, naô fe poderă alimpar o Caldo, como he bé,nas Caldeiras; \& ofogo queimaránas.Tachas ao Affucar, antes de fe cozer, \& bater. Poriffo nos Engenhos Reaes, que moem fete, \& oito mezes do anno:, fe tornaó a refazer todos os fundós das Caldeiras, \& Tachas.

As Peffoas; que aniftem nefta Cafa, faó o Meftre do Affucar, o qual prefide a toda a obra ; \& corre por fua conta julgar, fe o Calơo eftá já limpo , \& o Affucar cozido \& batido, quanto pede, para eftar em fua conta: affifte is temperas, $8 \times$ ao repartiménto dellás nas Formas; alem do que the cabe fa- 


\section{\& Opulencia do Brafl.}

zer na Cafa de Purgar, de que fallaremos nó feu propriolugar. A fua afliftencia principal he de dia : \& ao chegar da noite entra a fazer o mefmo $\oplus$ Banqueiro, que he comoo Contrameftre defta Cafa : \& da intelligencia, experiencia, \& vigilancia de hum, \& outro depende em grande parte ofazer-fe bom ; ou mao Afucar. Porque ainda que a Canna naó feja, qual deve fer; muito póde ájudar a Arte, no que faltou a Natureza. E pelo contrario pouco importa, que a Canna feja boa, fe o fruto della, \& o trabalho de tanto cufto fe botar a perder por defcuido, com naó pequeno encargo de confciencia para quem recebe aventajado eftipendio. Tem mais por obrigaçaō o Banqueiro, repartir de noite o Affucar pelas Formas, affentallas no Tendal, \& concertallas com fipó. E para lhe diminuir o trabalho neftas ultimas obrigaçoens, tem hum Ajudante de dia , a quem chamaó Ajudabãqueiro, o qual tambem reparte o Affucar pelas Formas, af fenta-as, \& concerta-as, comoeftá dito:

Revezaó-fe nas.Caldeiras oito Caldeireiros, divididos em duas efquipaçoens, hum em cada hũa, de affiftencia con: tinua atè entregalla a feu fucceffor; efcumando o Caldo que ferve, com Cubos, \& Tachos. Obrigaçaó de cada Caldeireiro, he efcumar tres Caldeiras de Caldo, que chanaaó tres Meladuras : \& a ultima fe chama de Entrega ; porque a deve dar meyolimpa ao Caldeireiro, que o vem render. E para eftas tres Meladuras, the ha de dar a Guindadeira o Caldo, que ha mifter, a feut rempo; a faber, acabado de efcumar, \& alimpar hüa Meladura; darlhe outra.

Nas Tachas trabalhaó quatro Tacheiros por efquipacoens de affiftencia, hum em cada Terno de Tachas: $\& \mathrm{tem}$ por obrigaçaô cada hum delles, cozer, \& bater tanto Aflitcar, quanto he neceffario para feencher hüa Venda de Formas, que vem a fer quatro, ou cinco Formas.

Serve finalmente para varrer a cafa, \& para concertar, \&

E

acen; 


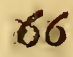

\section{Calcura,}

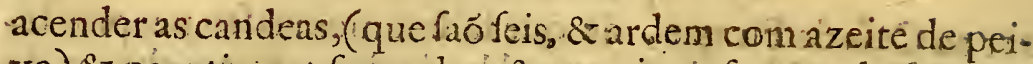
xe) \& para tirar as fegundas, \& terceiras efcumas do feu proprio Paról, \& tornalias a bótar na Caldeira; húr Effrava, a quem chamaó por alcunha A Calcanha.

He tambem efta Cara lugar de Penitentes : porque commummente fe vem nella huns Mulatos; \& huns Negros Crioulos exercitar o fficio de Tacherros, \& Caldeireiros, amarrados com grandes correntes de ferro a hum cepo, ou por fugitivos, ou por infignes em algum genero de maldade; para que defta forte o fcrro, \& o trabalho os amanfe. Wasentre elles ha tambem ás vezes alguns menos culpados, \& ainda innocentes; por fer o Senhor ou demafiadamente facil a crer o que lhe dizem, ou multo vingativo, \& cruel.

Os Inftrumentos, de que fe ufa na Cafa das Caldeiras, faó Efcumadeiras, Pombas; Reminhoes, Cubos, Pafídeiras, Repartideiras, Tachos, Vafculhos, Batedeiras, Bicas, Cavadores, Efpatulas, \& Picadeiras. Das Efcumadeiras, \& Pombas grandes ufaó os Caldeireiros: fervem as Efcumadeiras para alimpar : as Pombas, parabotar o Caldo de húa $\mathrm{Cal}$ deira para outra; ou da Caldeira para o Paról: \& poriffo os cabos, aflim de hũas, como de outras, tem quatorze ou qu inze palmós de comprido, parafe poderem menear bem: Os Reminhoes fervem para botaragua, \& decoada nas Caldeiras; \& para ajudaraos Tacheiros a botar o Aflucar na Repartideira, para ir ás Formas. Das Efcumadeiras mais pequenas, Batedeiras, \& Paffadeiras, Picadeiras, \& Vafculhos ufáo os Tacheiros da Repartideira, Cavador, \& Efpatulas o Ranqueiso, \& o Ajudabanqueiro: \& dos Tachos, Cubos, \& Bi ca ufa a Calcanha, para tirara efcuma do feu proprio 1 anól, \& para tornalia a pôr na Caldeira. Serve o Vafculho paratirar algūaimmundicia ao redor das Tachas : a Picadcira, para tirar o Affucar, que eftá como grudado mas nyefmas $T$ achas: \&r o Cavador, para fízer no bagaço do Tendal as covas, zonde fepoem as Formas.

C A- 


\section{Es Opuenciaido Brafl.}

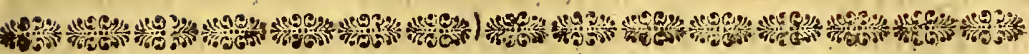

\section{A P I T U L O X.}

Do modo de alimpar, Es purificar o Caldo da Canna nas Caldeiras, Eo no Paról de coar, atè paJjar para as Tachas.

CUindando-feo cumo da Cañna (que chamaó Caldo)

I para o Paról da Guinda, dahí vay por húa bica a entrav na vata dos Cobres:: \&: o primeiro lugar, em que cae, he a Caldeira, que chamaó do Meyo, para nella ferver, 80 comecar a botar fóra a immundicia, con que vem dx Mtoenda. O fogofaz nefte tempo o fen officio; \& o Caldo bota fóra a primeira eícuma, a que chamaó Cachaça : \& efta por fer inm. mundiffima, vay pelas bordas das Caldeiras bem ladrilha. das fórada Cafa, por hum cano enterrado, que a recébe por liúa bica de pao, nietid a dentro do ladritho; que efláao rédor da Caldeira, '\& vay cahindo pelo dito cano $\mathrm{em}$ hum grande Cochoidepao, \& ferve para as Beftas, Cabras, Ovethas, \& Poircos : \& em algumas partes, tambem os Boys a lambem, porque turdo o que he doce, aind $x$ que immundo, deleita. $E$ para que o fogo naólevante a efcuma mais do que hejufto, \& dé lugar defealimpar o Caldo, como he bem; botxôlhe os Caldeireiros de quando em quando agua com hun Reminhòl : \& defta forte fe reprime a demafiada força da fervura, \& o. Caldo ainda immundo fe alimpa.

Sa hida a primeira efcuma perfi mefina, começaó os Caldeireiros com grädes efcumadeiras de ferro a efcumar o CaIdo, \& ajudallo : \& chamaó ajudar o. Caldo, o botarlhe de quando em quando jàtham Reminhòl de decoada, jà outro $\mathrm{E}_{2}$ 


\section{Cultura,}

de agua, que ahi tem perto: a agua nastinas, \& a decoada nas Formas. Serve a agua, para lavar o Caldo; \& a decoada , para que toda a immundicia, que refta na Caldeira, venha mais, dẹ preffa arriba, \& naó affente nófundo. Serve tambem para condenfar o Afucar, \& fazello mais forte; encoporando-fe conio Caldo, do modo quer fe encorpóra of fl com a agua. Efta fegunda Efcuma fe guarda, \& cae por outra bica da mefma borda do ladrilho para o larol mais baixo, \& afaftado do fogo, que fe chama Paról da Efcuma : \& dahicom cubo, \& tacho torna a botallo a Negra Calcanha, que tem ifto por officio, na mefma Caldeira, para fe purificar, 'que chamaó repaffar : \& vay por hũa bica de pao, encavilhada fobre hum efteyo de igual altura das Caldeiras, (a que chamaõViola, por imitar no feitio a efte inftrumento) larga no corpo, ou parte, em quie recebe a efcuma; \& eftreita no canno, por onde cae na Caldeira. E tanto que o Caldo apparece bem limpo, ( $\sigma$ que feconhece pela efcuma, \& pelo $s$ olhos, \& empolas, que levanta, cada vez menores, \& mais claros) com húa Pomba grande (que he hum vafo concavo de cobre,com feu cabo de pao comprido doze ou quinze palmos) o bótaó na fegunda Caldeira, que chamaó de Melar: \& aqui fe acaba de purificar; com o mefmo beneficio de agua \& decoada, atè ficar totalmente limpo.Deixa-fe alimpar oCal- , do na Caldeira do meyocoómummente pelo efpaço de meya hora: \&r já meyo purgado paffa a cahirna Caldeira de Melar por húa hora, ou cinco quartos, atéacabar de fe efcumar: \& nunca fe tira todo o Caldo das Caldeiras, por razaó dos Cobres, que padeceriaó detrimento do fogo; mas fe lhes deixa dous, ou tres palmos de Caldo, \& fobre efte fe bota o novo. A Efcuma tambem defta fegrunda Caldeira vay ao Paròl da Efcuma; \& dahi torna para a primeira, ou fegunda Caldeira atéo fim da Tarefa: \& defta: Efcuma tomaó os Negros para fazerem fua Garapọa, que he a bebida, de que mais goftaọ, 


\section{\& Opulencia do Brafll.}

goftaó , \& com que refgataó de outros feus Parceiros farinha, bananas, aipins, \& feijoens; guardando-a em potes atè perder a doçura , \& azedar-fe, porque entaó dizem que eftà em feu ponto para fe beber: oxalá com medida, \& naó atè fé emborracharem. A derradeira Eícuma da ultima Meladura,que he a ultima purificaçaó doCaldo, chamaó Claros: \& eftes mìfturados com agua fria, faó hūa regalada bebida, para refref-

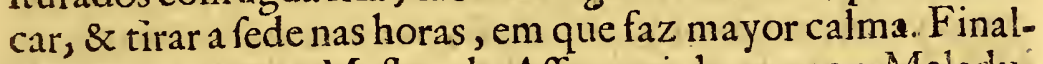
mente tanto que o Meftre do Affucar julgar que a Meladura eftálimpa ; o Caldeireiro com húa Pomba bota o Caldo, a que já chamão $\mathrm{Mel}$, no Paról grande, que chamaó Paról do Melado, \& eftá fóra do fogo, mas junto á mefma Caldeira; döde o coaó para outro Paról mais pequeno, ć chamaó $\mathrm{Pa}$ ról de coar, com pannos coadores eftendidos fobre húa grade. E para que naó caya alguma parte delle na paffagen de hum Paról para outro, \& fe perca; botaó-lhe húa telha de forma de purgar, que com o feu arco, \& volta abarca aos beiços de ambos os Paroes, por onde corre o Caldo, que cae no paffar da Pomba, \& vay a dar em hum, ou em outro Paról: 8:defta forte nem húa fó pinga fe perde daquelle doce liquor, que baftante fuor, fangue, \& lagrimas culta para fe ajuntar.

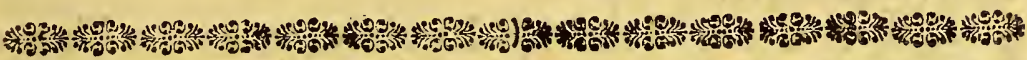

\section{A P I T U L O XI.}

Do modo de cozer, Ev bater o Melado nas Tacbas.

14 Standojá o Caldo purificado, \& coado, paffa a cozerfe nas Tachas, ajudadas de nayor fogo, \& chăma da que haó minter as Caldeiras; com tanto que os fundos tenhaó $\mathrm{E}_{3}$ agrof- 
70

\section{Cultura,}

a groffura baftante, para refiftir á mayor actividade, que nefte lugar fe requer. E fe o Melado fe levantar de forte, que ameace tresbordar; botandolhe hum pouco de fevo; logo amaina, \& fe calla. O que tal-vez tambem faria bǔa boa ra. $z a \sigma^{\prime}$, fe houvelle quem a fuggeriffe no tempo; em que a indiğnaçaó quer fahir fóra de feus limites. Dizem, que fe fe botafle qualquer liquor azedo nas Caldeiras, ou nas'Tachas, como verbi gratia çumo de limaó, ou outro femelhante; 0 Melido núnca fe poderia coalhar, nem condenfar, comofe pertende: \& allegaó cafos leguidos. Porém ifto naó parece fer certo, fallando de qualquer cafta de liquor azedo, fenaó do de limaó : porque já houve quem botou no Caldo Cachaça azeda em quantidade baftante, ou por fazer peça, ou por enfado, \& impaciencia; \& comtudo coalhou muito bem a feu tempo. Só de alguns animos fé verifica, que por hum le. ve defgofto bótaó a perder hum grande cumulo, \& naó de quaefquer beneficios. $O$ certo he, que em paffando o Mela. do, ou Mel para as Tachas, pede mayor vigilancia, \& attençaó dos Tacheiros, Banqueiro, \& Sotobanqueiro; \& Meftre : porque efte propriamente he o lugar, em que obra como Meftre intelligente, \& aonde he neceflario todo o cuidado, \& artificio.

Pafrando pois o Melado do Paról de coar para o Terno das Tachas, corre por cada húa dellas ordenadamente; \& pára em cada húa, quanto for neceffario; \& naó mais, para o $f \mathrm{~m}$, que em cada qual fe pertende. Na primeira Tacha, que fe chama a de receber, ferve, \& coneça a cozer-fe; \& felle tiraó as efcumas mais finas, que chamaó Nettas, \& fe bótaó com hũa pequena efcumadeira em hüa Forma, que ahi eftá pofta, \& fe as quizerem aproveitar, como he ben, faráó dellas no fum dafemana hum l'aó de Aflucar fomenos : porque efta Efcuma naó torna á Tacha; como torna a do Caldo ás Caldeiras. Da Tacha de receber, aonde eftá pouco tempo, paffa:fe 


\section{\&O Opulencia do Brafil.}

paffa-fe o Melado com húa Paffadeira de cobre (que he do feitio de hủa Pomba pequena)para a fegunda Tacha, naaó da Porta: \& aqui continuando a ferver, \& engrofar ; fe lançar de fi para a borda algúa immundicia, tira-fe, \& alimpa-fe ao redor com hum $V$ afculho, que he como hum pincel, ou efcova de imbîra, amarrado na ponta de húa vara: \& nefta Tachà fe deixa eftar mais tempo, atè ficar jà meyo cozido. Daqui com a mefma Paffadeira fe bota ura terceira Tacha, que chamaó de cozer : porque ainda que nas outras tambem fe coza; comtudo aqui acaba de fe cozer, \& de fe condenfar perfeitamente, até eftar em feu ponto, para fe bater : \& ifto o ha de julgar o Meftre, ou em feu lugar o Banqueiro, pelo corpo, \& groffura, que tem. E eftando defta forte, chamà-fe Melem ponto, groffo fufficientemente, \& compacto, \& jà difpofto para paffar á quarta $T$ acha, que chamaó Tacha de bater, aonde fe inexe com húa Batedeira, que he femelhante à Efcumadeira, mas com feu beiço, \& fem furos; \&c batefe, para fe naō queimar: \& quando o tem bem batido, \& com baftante cozimento, o levantaó com a mefma Batedeira fobre a Tacha ao alto, que póde fer; $8 \pi$ a iffo chamaó defáfogar, no que os Tacheiros moftraó deftreza fingular : \& continuaó aflim, mais, ou menos, conforme pedem as tres Temperas, que fe haó de fazer do Affucar, que ha de ir para as Formas. Das quaes Temperas, por ferem tam neceffarias, \& differentes, ferà bem fallar no Capitulo feguinte.

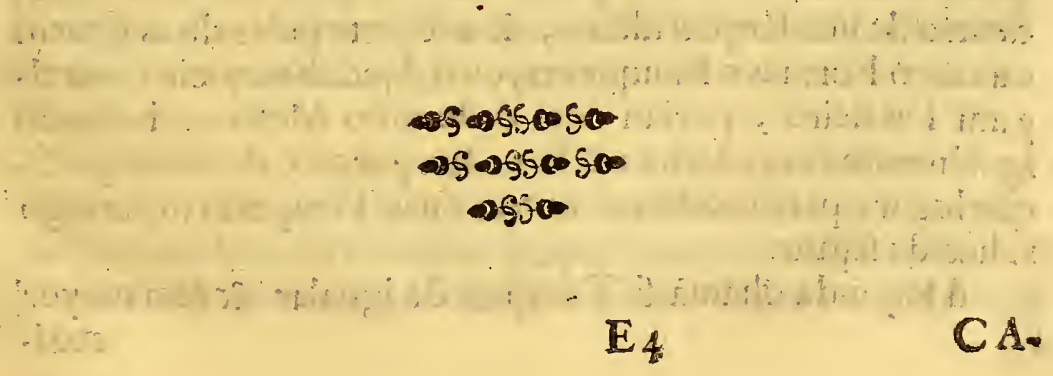




\section{2 \\ Cultura}

\section{A P I $\quad T$ U L O XII. \\ Das tres Temperas do Melado, Ef fua juftare- partiçaõ pelas Formas.}

A Nes de paffar o Melado para as Formas, eftandoain- 1 da na Tacha de bater, te ha de ajuftar o cozimento às Temperas, que pede a ley de bem repartir. E tres faó ellas, \& entrefi differentes; \& cada húa leva cozimento diverfo. Aflim por diverfos modos, \& com reperidas razoés procuramos temperar os animos alterados de qualquer. paixão vehemente.

Chama-fe a primeira, Tempera de principiar, ou Tempera de Bacia: a qual confta de Mel folto, porque tem menos cozimento; \& heo primeiro, que fe tira da Tacha de bater logo no principio, \& $x$ fe bota em húa Bacia fóra do fogo apar das Tachas com a Batedeira; aonde fe mexe com Efpatula, ou com Reminhól virado com a boca para baixo. E tendo ià o Banqueiro, ou o Ajudabanqueiro aparelhado quatro ou cinco Formas no Tendal, dentro de húas covas de bagaço, com feu buraco fechado, \& igualmente altas, ’̀s quaes chamaó Venda; fe paffa efta Tempera com Reminhól dentro de húa Repartideira, \& a reparte pelas ditas quatro ou cinco Formas o Banqueiro, ou o Ajudabanqueiro, ou algum Tacheiro, porèm com ordem do Meftre; botando igualmente em cada hũa dellas a fua porçaó, de forte que fique lugar, para receber as outras duas Temperas, que logo te haó de feguir.

A fegunda clama-fe Tempera de igualar: \& tem mayor. 


\section{Go Opulencia do Brafil.}

cozimento; porque o Mel, que traZ, tefteve mais tempo na Tacha de bater, \& ahi mexido; \& engroffada foy mais batido. E efta tambem tiradada Tacha, \& pofta, \& mexida com Reminhól na Bacia, paffa para as ditas quatro Formas na Repartideira, \& com igual porçaófe reparte por ellas; aonde com Efpatulas fe mexe mais que a primeira.

Segue-fe por ultimo a terceira, que chamaó Tempera de encher; a qual tem jà todo o cozimento, \& groffura neceffaria: \& com ella paffada para a Bacia, \& mexida ainda mais com Reminhól, \& levada na Repartideira para oTendal; feenchem as Formas, continiando com a Épatula a mexer nellas todas as tres Temperas, de forte que perfeitamente fe encorporem, \& de tres fe faça hum fo corpo. Efte beneficio he tam neceffario; que fem elle o Aflucar pofto nas ditas Formas, naō fe poderia depois branquear, \& purgar. Porque, fe fe botaffe nas Formas fó a Tempera, que tem cozimento perfeito; coalharia, \& fecondenfaria de tal forte, que naoo poderia paffar por elle a agua, que o ha de lavar, depois de fer barreado. E fe a Tempera foffe totalmente folta; efcorreria todo o Affucar das Formas na Cafa de purgar, \& fe desfaria todo em mel. Eaffìm có a miftura dás tres Téperas te coalha de tal forte, que fica lugará agua de paffar pouco a pouco; confervando-fe o Aflucar denfo, \& forte; : \& recebe o beneficio de fe branquear, fem o prejuizo de fe dérreter, fenaơ quanto bafta para perfeitamente fe purgar, Eachar efte meyo; com acertarbem nas Temperas, he a malhor indutria, \& artificio do Meftre:affim como efta he a mayor difficuldade no exercicio das virtudes, que eltaó no meyo de dous extremos viciofos.

O Melado, q fe dá em pratos, \& vafilhas para comer, heo da primeira, \& fegunda T empera. Do da terceira bem barido na Repartideira fe fazem as Rapaduras, tam defejadas dos Meninos: \& vem a fer Melado coalhado fobre hum quarto 
de papelcom todas as quatro partes levantadas, como fe forfemi paredes, dentro das quaes endurece esfriando-fe, de comprimento, \& largura da palma da mão. E bemaventurado oRapaz, que chega a ter hum par dellas, fazendo-fe mais de boa vontade lambedor deftes doces papeis, do que efcrivaó nos que lhe daó para trasladar alfabetos.

Com ifto fe entenderá donde nace o ter efta doce Droga tantos nomes diverfos, antes de lograr o mais nobre, \& 0 mais perfeito de Affucar : porque conforme o feu principio, melhoria, \& perfeiçaó, \& conforme os eftados diverfos, pelos quaes paffa, vay tambem mudando de nomes. Eaflim, na Moenda chama-fe çumo da Canna : nos Paroes do Engenho até entrar na Caldeira do meyo, Caldo: nefta, Caldo fervido: na Caldeira de Melar, Clarificado: na Bacia, Coado: nas Tachas, Melado: ultimamente Tempera : \& nas Formas Aflucár; de cujas diverfas qualidades fallaremos, quando chegarmos a vello porto nas caixas.

Os Claros, ou última efcuma das Meladuras, que, como temos dito, fervem para a Garappa dos Negros, fe lhes reparté alternadamente por efta ordem. No fim de húa Tarefa fe daó aos q́afifitem na Cafa das Caldeiras, \& nas Fornalhas: no fim de outra Tarefa fe daó ás.Efcravas, que trabalhaó na Cafa da Moenda: \& depois defta fe daó aos que bufcaó Ca: ranguejos, \& Marifco, para fe repartirem; \& aos Barqueiros, que trazem a Canna, \& a Lenha ao Engenho.|E fempre ferepete a diftribuiçaó com a mefma ordem; para que todos os que fentem o pezodo trabalho, cheguem tambem a tero feu pote, que he a medida, com que fé reparte êfte feu defejado Nectar, \& Ambrofia.

Quando fe manda parar, ou pejar o Engenho aos Domingos, \& dias Santes; tira-fe dos fundos das Tachas com hüa Picadeira de ferro o Melado, que frcou nelles grudado ; porque com efte naô poderiaó esfriar-fe: \& a lem difto fe lhes bo- 


\section{o Opulencia do Brafll.}

ta agua , para que fe naó queiniem os Cobres ; \& ferve junta: mente para os lavar : \& aflim fédeixaó as ditas Tachas, até entrar nellas o Mel, ique fe ha de cozer.

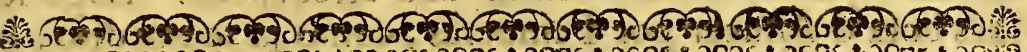

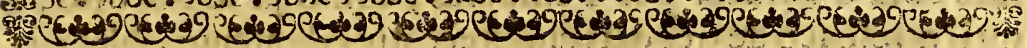

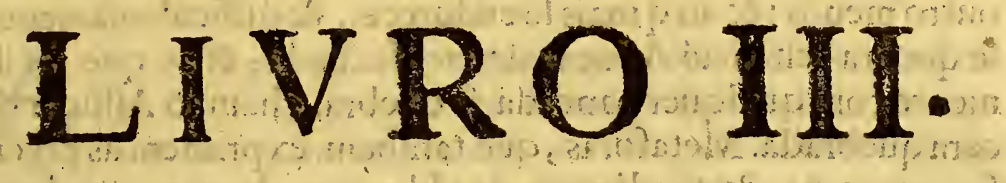

\section{A P I T V O I.}

Das Formas do AJjucar, \& Sua pajJagem do Tendal pars a Cafade purgar.

Aóas Formas do Aflucar huns vafos de barro queimaS do na fornalha das telbas; \& tem algūa femelhança com os finos, altas tres palmos \&z meyo, seproporcionadamente largas, com mayor cincumfetenciana boca, \& mais: apertadas no fim, aonde raó furadas, parife lavar, \& purgar - Affucar por efte buraco. Vendiaó-fe por quatro vintens: falvo fe a falta dellas, \& o defcuido de as procurar a feu tem po lhes acrecentaffe o valor.

O feren de ruim barro, \& $\mathrm{mal}$ queimadas, he defeito notavel ; como tambem oferem pequenas. As boas faó capazes de dar Páes de tresarrobas \& meya. Tem na Cafa das Cal. deirasfeu Tendal, cheyo de bagaço de Canna, que vem da bagaceira; o qual cavado coni hum Cavador de ferro, ou de pao, ferve de cama, ou cova, para nelle fe aflentarem as Formas direitas em duas fileiras iguaes : \& como temos dito aci$\mathrm{ma}_{2}$ de cada quatro ou cinco Formas confta hũa venda. An- 
76

\section{- Cultura,}

tes de botar nellas o Affucar, fe lhes tapa o buraco, que tem no iundo, com feus tacos de folha de bananna, \& fe affeguraó com arcos deSipó , : \& cannabrava, para que com a demafiada quantidade do Aflucar naó arrebentem. Logo fe Thes bota o Affucar por Temperas, como já temos dito; o qual no ef paço de tres dias endurece div erfamente, hư mais, outro menos: \& ao q́ mais fe endurece, \& difficultofamente fe quebra, chamaó Affucar de cara fechada ; \& ao que facilmente com qualquer pancada fe quebra, chamaó Affucar de cara quebrada. Metaforas, que tambem exprimem as diverfas naturezas, \& condiçoens dos Homens : huns tam vidrentos; \& outros tam tolerantes. E de fer bom, ou mao o Affu. car, depende o fazer as Vendas de mais, ou menos. Formas. Porque para obom, que coallia depreffa, bafta tomar quatro Formas: \& para o que coalha mais de vagar., tomaô-fe feis, fete, \& oito Formas, para que crie com o mayor tempo, que he neceffario para as encher todas, mais graó. Dahi paffa às coftas dós Negros, ou fobre paviôlas para a Cafa de purgar, da qual logo fallaremos.

Faz hum Engenho Real de dons ternos de Tachas, fea Canna render bem, cada femana folteira perto, \& pafsante de duzentos Páes de Afsucar : mas fe naó render; apenas dá cento \& vinte. E o render pouco, nace ou de fer a Canna muito velha, ou de fer muito aguacenta : prova bem clara de ferem os extremos, quaefquer que fejaó, viciofos. 


\section{\&. Opuleniciado Brafl.}

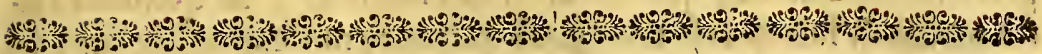

\section{A P I T U L O II.}

Da Caja de purgar o Affucar nas Formas.

A Cara de purgar he commummente feparada do EdiA ficiodo Fingenho: \& a melhor de quantas ha no Reconcavo da Bahia, he fem duvida a doEngenho de Serigippe do Conde, fabricada de pedra, \& cal, emmadeirada com paos de Maffarandûba, \& cuberta com todo oaffeyo de telhas, de comprimento de quatrocentos \& quarenta \& feis palmos, \& oitenta \& feis de largura; dividida em tres carreiras de andainas, com vinte \& feis pilares de tijolo no meyo, altos 'quinze palmos \& meyo, \& largos quatro, para fuftentarem o tecto, que affenta ao redor fobre paredes largas, \& fortes. Recebe efta Cafa a luz, \& ar neceffario por cincoenta \& duas janellas, altas oito palmos, \& largas feis, vinte \& tres de cada banda, tres na fachada com fui porta, \& tres na teftada. Repartemfe as andainas por quarteis de taboas abertas en redondofobre pilares de tijolo, altos da terra fete palmos; $\&$ leva cada taboa dez deftas aberturas, para receber outras tantas Formas; de forte, que por todis faó capazes de purgar commodamê. te no mefmo tempo ate a dous mil Paens. Debaixo das ditas. taboas afiim abertas ha outras tantas taboas do mefmo comprimento, cavadas á maneira de regos, \& inclinadas na parte dianteira, que fervem de bicas, ou correntes, poronde corre o $\mathrm{Mel}$, que cae dos buracos das Formas, em que fe purga - Affucar, aos. Canques enterrados : \& ha no fim húa Fornatha, para o cozer, \& tornar a fazer delle Affucar, com feu: Tendal capaz de quarenta Formas. Ha tambem na entrada á maồ efquerda da porta hüa cafinha de madeira, para nella guario 
78

\section{Cultura}

guardar o Affucar, que fobejou ao encaixar ; \& quantos In. ftrumentos faó neceffarios para barrear, mafcavar, fecar, de encaixar: \& o primeiro efpaço da Cafa de purgar, capaz de trezentas Cuixas, antës dechegar ẩs andainas das Formas, ferve da Caixaria mais refguardada, \& fegura, có a porta ao Poente, para que gozando toda a tarde do'Sol, defenda có o feu calor ao Affucar do mayor inimigo, que tem depois de feito, \& encarxado; que he a humidade.

Diante da porta da Cafa de purgar levanta-fe fobre feis pilares hum Alpendre de oitenta \& dous palmos de compri mento, \& vinte \& quatro de largo, debaixo do qual eftà o Balcaó de mafcavar : \& da outra parte eftá o Cocho para amaffar o barro, que fe bota nas Formas, para purgar o Aftucar: \& mais adiante o Balcaó para o fecar, comprido oitenta palmos, \& largocincoenta \& feis, fuftentado de vinte \& cinco pilares de tijolo, mais alto no meyo, \& com baftante inclinaçaó nos lados, para efcorrer melhor a agua, que cahir do Ceo, \& fer de mais dura. Epara iffo ferve tambem for feito de pao de ley, a faber, de Maflarandûba, de Vinhatico, capaz de feffenta toldos, \& de fecar no mefmo tempo outros tantos $P$ aés de Affucar.

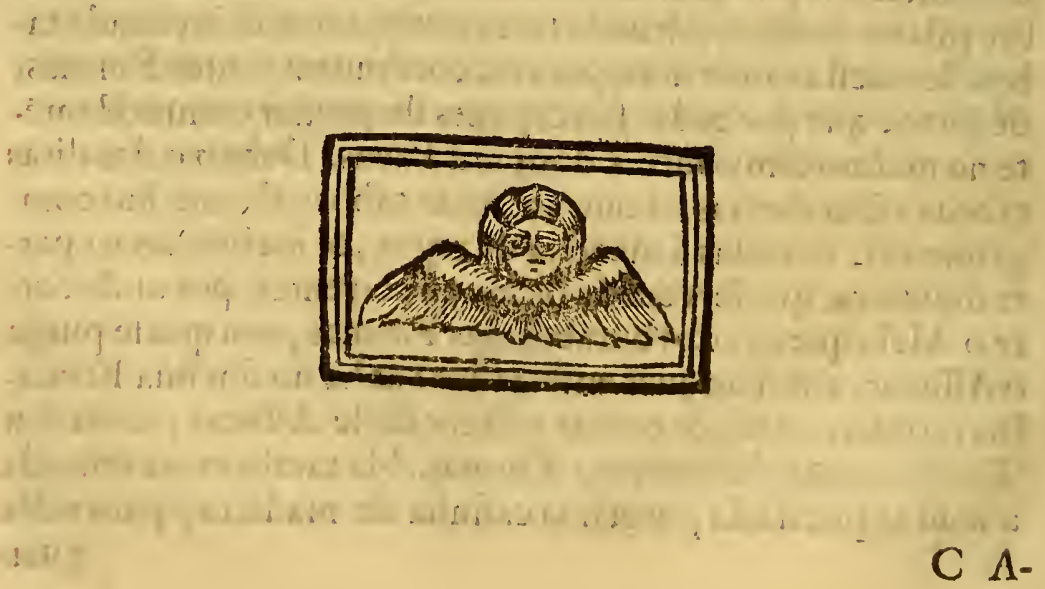




\section{¿́ Opulencia do Braßz.}

4.

\section{A P I T U I O HI.}

Das Peßoas, que fe occupaŏ em purgar, mafcas var, fecar, $\sigma^{-}$encaixar o AjJucar : $\sigma$ dos Instrumentos, que para i.jo fao necessarius.

A. Onde naóha Purgador, (quefempreferia bem tello) A prefide tambem na Cafa depurgar o Mefte de Affucar, a quem pertence julgar, quando fe ha de botar o primeiro, \& o fegundobarro nas Formas ; quando fe ha de humedecer, \& borrifar mais, ou menos, conformea qualidade do Artacar; \& quando fe ha de tirar o barro, \& o Afucar das Folmas. Mas, ainda que haja Purgador ditinto com fua foldada; fempreferábem, que efte fe aconfelhe com o Meftre, para obrar com mayor acerto; \& que tenhaó a mbos entre fi toda a boa correfpondencia, para que fiquem melhorfervidos aflim o Senhor do Engenho, como os Lavradores, \& elles mais acreditados em fens officios.

Prefide ao Balcaó de mafcavar, \& de fecar, \&r ao pezo, \& ao encaixar do Affucar o Caixeiro: \& corre por fua conta repartir, \& affentarcomtoda a verdade, \&zfidelidade oque cabe a cada qual de fua parte: pregar, \& marcaras Carxas, \& entregallas afeus donos:

Trabalhaón a Cafa de purgarquatro Efcravas, \& faó as que entaipaó, \&r bótaó barro nas Formas do Affucar, \& the daó fuas lavagens. No Balcaŏ de'mafcavar affiftem duas. Negras das mais experimentadas, que chamāo Mays do Balcaō; \& com-ourtras'o mafcavaó, \& apartaố o inferion do melhor: kuns 
huns Negros, que trazem, \& aventaó as Formas, \& tiraó dellas os Paés de Afsucar; \& o Amafsador do barro de purgar, que he tambem outro Negro.

No Balcaó de fecar trabalhaoo as mefm as duas Mãys com as fuas companheiras, que faó atè dez, eftendendo os Toldos , \& quebrando com toletes as lafcas, \& os torroés grandes em outros menores atraz dos quebradores dos Paés. E na Caixaria ajudaó ao Caixeiro no pezo, \& encaixamento do Afsucar as Negras, \& Negros, que faó necefsarios; como tambem no pilar, igualar, pregar, \& marcar.

Os Inftrumentos, de que fe ufa na Cafa de purgar, faó Furadores de ferro, para furar os Paés em direitura do buraco das Formas; Cavadores tambem de ferro, para cavar o Paó no meyo da primeira Cara, antes de lhe botar o primeiro, \& fegundo barro; \& Macetes, para o entaipar. No Bale caợ de mafcavar ufaó de couros, para aventar fobre elles as Formas; de Facoens, \& Machadinhos, para maficavar; \& de Toletes, para quebrar o Afsucar Mafcavado. No Balcaó de fecar fáo necefsarios Facoés, 'Toletes, \& Rodos , \& o Pao quebrador de quatro lados de cofta para quebrar c $s$ Paés de Afsucar. No Pezo, balanças, pezcs de duas arrobas, \& outros menores, com o da tara; Pás, \& Panacûs. Na Caixaria, Piloens, Rodo, Paodealsentar, ao qual huns chamaó Moleque de afsentar; \& outros Juiz, Enxó, Verrumas, Martellos, \& Pregos; Pé de Cabra, para tirar pregos das Caixas; \& o Gaftalho, que ferve para unir as taboas racha: das, ou abertas, metendo fuas cunhas entre os lados da taboa, \& os dentes, ou baraços do Gaftalho, q́ a abraça por cima, \& dece pelas ilhargas; \& as Marcas deferro, com que fe marca, \& declara a qualidade do Afsucar, o numero das arrobas, \& o finaldo Engenho, em que fe fez, \& encaixou. E defta forte, qualquer Arte fe val de feus Inftrumentos, para far cilitar o trabalho, \& fahir com fuas obras perfeitas; o q́ fem elles naó poderia alcançar, ñem efperar.

C A- 


\section{SOpulencia do Brafil.}

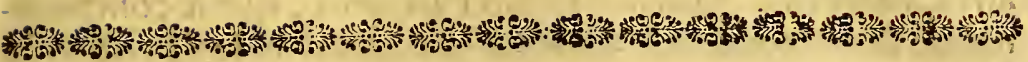

\section{A P I T U I O IV.}

Do Barro, que se bota nas Formas do Afsucar: qual deve fer, Eo como se ba de ama/sar : E se be bern ter no Engenho Olaria.

Barro, com que fe purga o Affucar, tira-fe dos Api- cús, que, comotemos dito, faóas Coroas, que fazo Marentrefi, \& a Terra firme, \& as cobrea Maré. Vem efte em Bar cos, Canoas, ou Balças, que faoo duas Canoas juntas com paos atraveffados; \& fobre elles taboas, nas quaes fe amontoa o Barro. Chegado ao Engenho, poem-fe em lugar feparado; \& dahi pafla a fecar-fe dentro da Cafa das Fornalhas fobre hú andar de paos fegurado com efteyos, q́ chamaō Girâo, fobre o Cinzeiro, quando tem feu borralho, qu he a cinza mifturada com brazas. E ainda que fe feque em quinze dias; comtudo ahi fe deixa, tomando a feu tempo a quătidade, que for neceffaria, para barrear as Formas já cheas, como fe dirá em feu lugar. Seco fe desfaz com Macetes, que faó paos para pizar; \& dahi fe bota em húa Canoa velha, ou Cochogrande de pao, \& fe vay desfazendo com agua, movendo-o, \& amaffando-o com feu Rodo o Negro Amaffador, que fe occupa nefte trifte trabalho; pois os outros E[cravos, que cortaó, \& trazem Canna, \&r os que obraôn na Moenda, nas Caldeiras, nas Tachas, na Cafa de purgar, \& nos Balcoês, fempre tem em que petifcar: \& fó efte miferawel, \&r os que metem lenha nas Fornalhas, paffaó em feco. $\mathrm{E}$ ainda que depois todos tenhaó fua parte na repartiçaō da Garappa; com tudó fentem muito o trabalho fem efte limitado alivio 
alivio entre dia. Mas naố faltaó Parceiros, que fe compadeçá da fua fórte, dando-lhes já hǘa Canna, já hum pouco dê $\mathrm{Mel}$, ou de Affucar: \& quindo faltaffe nos outros a compaiXaó; naó faltaria á elles a induftria, para bufcarem feu remedio, tirando donde quer quanto podem.

O final de eftâr bent ämäfrado o Barro, he naó ter já godilhoeñ, que faó huns torrōêfinhos ainda naố desfeitos: \& entaó eftá em feu ponto, quando botando-lhe hum pedaço de tetha, ou hum caco de Forma, fe fuftem na fuperficie, fem ir ao fundo. Do Cochofe tira com hüa Cuya, \& fe bota em tachos de cobre, '\& nelles o levaó para a Cafa de purgar : aonde com hum Reminhól de cobre fe tira dos tachos, \& fereparte pelas Formas, quando for tempo, do modo que fe dirá mais abaixo.

Ter Olaria no Engenho, huns dizem, que efcufa maycres gaftos; porque fempre no Engenho ha neceffidade de Formas, tijolo, \& tellha. Porèm outros entendem o contrario: porquea Fornalha da Olaria gafta muita lenha de armar; \& muita de caldear: \& a de caldear ha de fer de Mangues; os quaes tirados, faó a deftruiçaó do Marifco, que he o remedio dos Negros. Ealem difto, a Olaria quer ferviço de feis, ou fete Peças,que melhor fe empregaó no Cannaveal, ou no Engenho: quer Oleiro com foldada, Roda, \& apare. Tho: \& quer Apicus, ou Barreiro, donde fe tire bom Barro: \& tudo ifto pede muito gafto: \& $\mathrm{com}$ muito menos fe compraó as Formas, \& as Telhas, que faó neceffarias. O melhor confelho he, meter hum Crioulo em alguma Olaria : porque efte ganha a ametade do que faz, \& em hum artinchega a fa. zer tres mil Formas, das quaes o Senhor fe póde valer com pouco difpendio. Tendo porèm o Senhor do Engenho mujta gente, lenha, \& Mangues para marifcar de fobejo; poderá também ter Olaria : \& fervirá efta Officina para grandeza, utilidade, \& commodidade do Engenho. 


\section{\&Opulencia do Bra/al.}

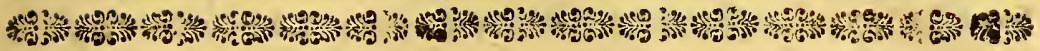

\section{$\begin{array}{lllllllll}\text { C } & \text { A } & \mathrm{P} & \mathrm{I} & \mathrm{T} & \mathrm{U} & \mathrm{L} & \mathrm{O} & \mathrm{V} \text {. }\end{array}$}

Do modo de purgar o A Asucar nas Formas : $\mathcal{F}^{\circ}$ de todo o beneficio, que se lhe faz na Cafa de Purgar, ate se tirar.

7 Ntrandoas Formas na Cafa de Purgar, fe deitaó fobre as Andainas, \& fe lhes tira o taco, que lhes metèraóno Tendal: \& logocom hum Furador agudo de ferro, de come primento de dous palmos \& meyo,fe furaó os Paẹs á forçade pancadas, ufando para iffo do Macete; \& furadus, fe levantaó, \& endireitaó as Formas fobre as ta bas, que chamaó de furos, entrando por elles quanto bafta para fe fufterem feguras: \& allim fe deixaố por quinze dias fem barro, começand o logo a purgar, \& pingando pelo buraco que tem , o primeiro Mel: o qual recebido debaixó nas bicas, corre atè dar no feu Tanque. Efte Mel he inferior, \& dá-fe no tempo do Inverno aos Efcrayos do Engenho, repartindo a cada qual ca. da femana hum tacho, \& dous a cada cázal; que he o melhor mimo, \& o melhor remedio, que tem. Outros porèm o tornaó a cozer, ou o vendem paraiflo a os que fazem delle Affucar branco batido, ou eftill laó Agua ardente.

Paffadorios quinze dias, dahi por diante fe póde barrear feguramente : o que fe faz defte modo. Cavaó primeiro as quatro Efcravas Purgadeiras com Cavadores de ferro no meyo da Cara da Forma ( que he a parte fuperior)o Affucar já feco; \& logo o tornaóa igualar, \& entaipar muito bem com Macetes : botaó-the entaó o primeiro barro, tirando-o $\mathrm{F}$. $\operatorname{coin}$ 


\section{4}

\section{Cultura,}

com hum Reminhól dos Tachos, que vica a cheyos delle do feu Cocho, eftandojá amalfado em fua conta; \& com a palma da maó o eftendem fobre toda a Cara da Forma, alto dous dedos. Aoregundo, ou terceiro dia, bóraó en riba do mefmobarromeyo Reminhól; ou hía Cuya \& meya de agua: \& paraque naó caya no barro de pancada, \& cahindo faça covas no Affucar; recebem fobre a maô ef querda, chegada ao barro, a agua, que bótaó com a direita igualmente fobre to. da a fuperficie : \& logo com a palma da maó direita mexem levemente a barro, de forte que com os dedos naó cheguem a bulir na Cara do Afrucar. E a efte beneficio chamaó biumedecer, borrifar, \& dar lavagens, ou tambem dar humidades: \& deftas o primeiro barro naó leva mais que húa; \& eftá na Forma feis dias, donde fe tira jà feco, \& cava-fe outra vez o Affucar no meyo, como fe fez ao principio, \& entaipa-fe; $\&$ com a mefma diligencia fe lhe bora of fegundo barro, o qual eltá na Forma quinze dias, \& leva feis, fete; \& nuis humidades, conforme a qualidade do Affucar : porque o que he forte, quer mais humidades, refítindo á agua, que ha de correr por elle purgando-o, às vezes atè nove, \& dez humidades. E fe for fraco, logo a recebe, \& fica em menos tempo lavado: mas difto naố fe alegra o dono do Affucar; porque antes o quizera mais forte, do que tam de preffa purgado. Tambem noV eraó he neceflario repetir as lavagens mais vezes, a faber, de dous em dous, ou de tres em tres dias, conforme o calor do tempo :-advertindo de the dar eftas lavagens, antes que o barro chegue a abrir-fe em gretas por feco. Notempodo Inverno tamben fe deixa o primeiro barro feis dias: \& alguns naó lhe diá outra bumidade mais que a que traz comfigo; principalmente fe forem dias de chuva. Porém tirado o primeiro, \& pofto ofegundo, daó-lhe feis, fete, \& oito humidades, de tres em tres dias, conforme a qualidade do Aflucar \& 2 conforme obedic cer is ditas lavagens.

Como 


\section{¿o Opulencia do Brafll.}

Como o Affucar vay purgando, affim fe vay branqueando por feus graos: a faber, mais na parte fuperior, menos na do meyo, pouco na ultima, \& quafi nada nos pés das Formas, aos quaes chamaó Cabuchos : \& efte menos purgado he o q́ fe chama mafcavado. Tambem como vay purgando, vay decendo o barro pouco a pouco dentro da Forma : \& fe purgarbem de vagar, decendo fó meya maó, que chamaó Medida de chave, \& vem a fer defde a raiz do dedo polegar atè a ponta do dedo moftrador, a purgaçaó ferá boa, \& de rendimento de mais Affucar, \& forte : mas fe purgar apreffadamente, renderá pouco.

O purgar-fe mais depreffa, ou mais de vagar o Affucar nas Formas, nace, parte da qualidade da Canna boa, ou má; \& parte do cozimento feito , \& temperado em feu ponto. Porque, fe o cozimento for mais do que he jufto, ficará o Affucar empanturrado, \& nuinca fe poderá purgar beni; refiftindo às lavagens naó por forte, mas por demafiadamente cozido: \& ifto fe conhecerá de naó purgar, \& de naó decer o bạrro nas Formas. Pelo contrario, fe o Affucar levar pouco cozimento; \& a Tempera for muito folta, irá pela mayor parte desfeito em Mel para as correntes. O fazerem os Paens do Affucar olhos, ifto he, terem entre o Affucar branco veas de Mafcavado; huns dizem, que procede de botar mal as humidades no barro das Formas; \& outros das Temperas mais ou menos quientes, ou defigualmente botadas.

$\mathrm{O} \mathrm{Mel}$, que cae das Formas depois de lhes botarem barro, torna a cozer-fe, $\&$ a bater-fe nas $T$ achas, que para iffo eftaó deftinadas, com fua Bacia : \& fél faz delle Af̂lucar, que chamaó Branco batido; \& dá tambem feu Mafcavado, que chamaó Mafcavado batido. Ou fe eftilla delle Agua ard ente: que eu nunca aconfelharia ao Senhor do Engenho; para naó ter húa continua defenquietaçaó na fanzâla dos $\mathrm{Ne}$ gros : \& para que os feus Efcravos, \& Efcravas naó fejaó com $\mathrm{F}_{3}$ a Agua 


\section{Cultura,}

a Agua ardente mais borrachos do que os faz a Cachaça.

O. primeiro barro, que fe poz na Forma alto dousdedos; quando fe tira jà feco, tem fó altura de hum dedo, que he de. pois de feis dias: quando fe tira o fegundo, (que fe botou com a mefma altura de dous dedos) depois de quinze dias; tem fó meyo dedo de altura. Acabando o Affucar de purgar, päraó tambem as lavagens: \& tres, ou quatro dias depois da ultima , tira-fe o fegundo barro já feco; \& depois do barro fóra, dao-the mais oito dias, para acabar de enxugar, \& efcorrer: \& entaó fe póde tirar. Né carece de admiraçaó; o fer obasro, q́ de fua natureza he immundo, inftrumento de purgaro Affucar com fuas lavagens : afim como com a lembrança do noflo barro, \& com as lagrimas fe purificaó, \& branqueaó as Almas, que antes eraó immundas.

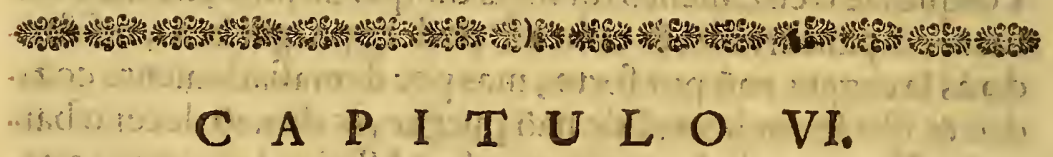

Do modo de tirar, nafcavar, EJecar o Af sucar.

Wegado o tempo de tiraro Affucar das Formas, fe paffaráo em hum dia muito claro tantas, quantas póde receber o Balcaó de fecar:\& paffaó ás coftas dos Negros, ou em Paviôlas, da Cafa de purgar para o Balcaó de mafcavar. E quanco ao fero dia muito claro; he ponto de grande advertencia : porque feo Aflucar fe humedecer; ainda que o tornem pór ao Sol, nunca mais tórnala fer perfeito, como era: antim como o que ficou de hum anno para outro, perde de tal forte o vigor, \& alvura, que nunca mais a torna a cobrar: propriedade tambem da Pureza, que hũa vez ofiendida, nú-

ca tor- 


\section{\& Opulencia do Brajl.}

ca torna a fer o que foy. Prefide a todo efte beneficio o Caixeiro; "\& corre por fua conta o que agora direy. Ao pé do Balcaó ; que chamaó de mafcavar, fe av'entaó as Formas fobre hum couro; quevem a fer, bulir nellas de vagar com as bocas viradas para o dito couro, para que fayaó bem os Paés: os quaes poftos fucceffivamente por hum Negro fobre hum toldó, que eftà eftendido nefte Balcaó; por maó de hũa $\mathrm{Ne}$ gra (à qual chamaó Mãy do Balcaó) fe lhes tira cóm hự fácaótodo aquelle Affucar mal purgado, \& de cor parda, que tem na parte inferior : \& ifto fe diz mafcavar, \& ao tal Aflucar chamaó depois Mafcavado. E entre tanto outra fun Companheira, que he das mais praticas, tira com hum machadinho do mefmo Mafcavado o mais humido, que chamá Péda Forma, ou Cabucho ; \& efte torna para a Cafa de purgar em outras Formas, até acabar de fe enxugar : \& logooutras Negras quebraó com toḷetes os torroens do Mafcaxiado fobre hum Toldo, que tambem ha de ír ao Balcaố de fecar.

A perfeiçaó dos Paens confifte em terem pouco Mafcavado, \& darem duas arrobas \& meya de Affucar branco; que conforme a medida das Formas da Bahia, he muito bom rendimento. Se quizerem fazer Caras de Affucar paramimos; ó Cxixeiro cortarà aqui mefmo có hum facaó a primeira parte do Paó, de forte que endireitada, \& aplainada tenha húa arroba de pezo: \&r eftas depois de eftarem ao Sol, empalhaôfe, ou encouraó-fe, \& vaó para o Reỵno. Tambem, fequizer fazer Lafcas; cortarà ao Paó (depois de fe lhe tirar o Mafcavado') em feis, ou oito partes, \& as endireitarà todas de quátro cantos em quadra; para irem tam viftofas; como docés. E querendofazer Fechos, ou Caixas de encommenda; fefothera da parte do Affucar, que couber a quem as manda fat zer, omais fino, que he o das Caras das Formas, atédozearrobás por Fecho; \& trinta atè trinta \& cinco por Caixa. E do que temos dita atè agora fe entenderà bem o quequeren di$\therefore \rightarrow+y^{-1}$

$\mathrm{F}_{4}$

zer 


\section{8}

\section{Cultura,}

zer eftes nomes, que fignificaó varias repartiçoens de Affucar; a faber, Caixa, Fecho, Paó, Cara, Lafca, Torraó; \& migalhas : guardando para outro Capitulo o dar noticia de varias qualidades, \& differenças de Affucar.

Paffando pois do Balcaó de mafcavar para o: Balcaỏ de fecar: leváo-fe em primeiro lugar para elle tantos Toldos; quantos faóneceffarios para o Affucar, que naquelte dia fe ha de fecar. Efe for de diverfos donos, fe conheceri a reparriçaó, que cabe a cada qual, pelos Toldos continuados na mefma fileira, fe pertencerem ao mefmo; ou defcontinuados, fe forem de diverfos Senhores : \& o que fe diz do Anucar Branco, fe hade dizer tambem do Mafcavado, repartido pelo mefno eftylo nas fuas proprias fileiras. Ifto feito, levaō os Paens para os Toldos, \& com hum pao grande, \& redondo no cabo, em que fe pega, \& no remate de feitio chato, ccmo húa lança fenı ponta, ( a qual chamaó Quebrador, ou Moleque de quebrar ) quebraó em quatro partes aos. Paens, \& cada húa deftas em outras quatro: \& logo outros com facoens dividem as mefmas em torroens; \& eftes fucceflivamente fe tornaó a partir com toletes, em outros torroens menores : \& finalmente depois de eftarem jà por algum tempo ao Sol, acabaō-fe de quebrar em torroéfinhos pequenos. E guarda-fe de propofito efta ordem em quebrar ao Affucar; para que tendo dentro algúa hunidade, quebrado pouco a poucofe enteze, \& naó fe faça logo cm migalhas, ou em pó. Eftando alim eftendido, pegaó nas pontas dos Toldos, \& levantando-as fazem em cada Toldo hum montàó; \& entretanto aquentiló-fe as Taboas, \&r os Toldos : \& logo tornaó, a abrir aquelles montes com Rodos; \& defta forte as partes, qúle eraó interiores, ficaó expoftas ao Sol ; \& as outras eftendidas fobre as pontas dos. Toldos, fentem o calor, que elles, \& as Taboas ganhâraó. Efpalhado torna-fe a mexer com Rodos, de Camboâ. ${ }_{2}$ como elles dizem : a faber, hum de hũa 


\section{EO Opuicricia do Brafil.}

bañda, \& outro de outra, empurrandò cada hum da fua par-: teo Affucar, \& puxando por elle por modo oppofto ao que faz no mefmo Toldo o Negro fronteiro; atè a cabar de fecar. $E$ fe de repente apparecer alguma nuvem, que ameace dar: chuva, logo acode toda a Gente, ainda (fe for neceffario) a que trabalina na Moenda spejando o Engenho, até fe recolher nos mefinos Toldos o Affucar dentro da Cafa de encai-? xar, ou em outra parte cuberta : $\&$ daqui torna outra vez para o Balcaó em outro dia claro, eftando as Taboas enxutas. Que fe o tem po der lugar de enxugar perfeitamente o Affucar no mefmo dia no Balcaó; paffará logo (do modo, que agora direy) ao Pezo, \& fe encaixará com fúa regra.

*

\section{A P I T U L O VII.}

Do Pezo, Reparticăo, E Encaixamento do $A$ ssucar.

1. O Balcaó de fecar vay o Affucar em Toldos ao Pezo, eftando prefente o Caixeiro, quido affenta com fidelidade, \& verdade; para qufe dé juftamente acada hum o đ̃ he feu.E para iffo haBalanças grandes, \& pezos de duas arrobas; \& outros menores de livras, com o pezo tambem da tara do Panacú, em que vayo Afucar ao Pezo: ufardo de Pá pequena, para tirar o que fobeja, ou ajuntar o que falta. E aflim como as duas Mãys:do Balcaóajudaóa ao pezo, para dar lugat ao Caixeiro, que eftá affentando o que peza; affim dous: Negros levaó o Affucar pezado para as Caixas , enxutas, \& bem aparelhadas, a faber, barreadas por dentro nas untas combarro, \& folhas fecas de bananeira folbre obarro

porf- 
20

\section{1) Cultura.}

pondo igualmente tanto Afucar na Caixa do Senhor do Engenho, quanto na Caixa do Lavrador, suja Canna fe moeo no meimo Engenho, fendo Lav rador de fuas proprias Terras, \& naó das do Engenho:: porque fe as Terras forem do Engenho, paga tambem o: Lavrador vintena, ou quinto, que vem a fer,; alem da ametade, de cada cinco Paens hum, ou hum de cadavinte, conforme o ufo das Terras : porque en Pernambuco paga quinto, \& na Bahia vintena, ou quindena, que vem a fer de quinze hum, conforme o que fe aiuftou nos arrendamentos, por ferem as Terras já de rendimento; ou por neceflitarem de menos limpas: E aflim como fe péza; \&r reparte igualmente o Branco; afim fe péza, \&r reparte. do mefmo modo o Mafcavado entre o Senhor do Engenho, \& o Lavrador, que moe, como temos dito, de meyas : \& fó ficaó os Meles por em cheyo ao Senhor do Engenho, por razaó dos muitos gattos, que faz. Tirafe tambem o Dizimo, que 1 e deve a Deos, que vem a fer de dez hum : Sr efte fica no Engenho, \& poem-fe nas Caixas \& que anticipadamente manda o Contratador dos Dizimos ao Caixeiro vazias, \& delle as torna a cobrar cheas.

O Affucar, q́ fe bota nas Caixas, ao principio fómente fe iguala com Rodó,\& Piloés; \& naó fepila, para đ̆ fe naó quebrem as Caixas. Porèm depois de botar nellas dous, ou tres pezos,q́ vem a fer quatro, ou feis arrobas, entaó fe pila có aito oudez Piloens, quatro ou cinco de cada banda, para queaffente unido igualmente. E ainda que a derradeira porçá do Affucar, q́ fe chama Cara da Caixa, he bem á feja do mais efcolhido; com tudo feria grande defcredito do Engenho, engano, \& manifefta injuftiça, fe no meyo fe botaflem Batidos, \& na Cara Affucanmais fino, para encubrir com obom oruim, \& fazè tambem ao Affucar"hypocita.

Acabado de encher a Caixa, iguala-fe com Rodo, \& com hum Paochato, \& groffo, que huns chamaó-lhe.Moleque de 


\section{Eo Opulenciado Brafil.}

\section{9i}

affentar, outros fuizis \& logo le prega, ufando de-Verruma, Pregos, \& Martello, \& do Gaftalho, ou Gato, para apertar alguma taboa rachada, do modo que acima eitá dito. Leva hŭa Caixa oitenta \& feis pregos: $\&$ ultimamente fe marca do modo que diremos, conforme a differença do Affucar, que

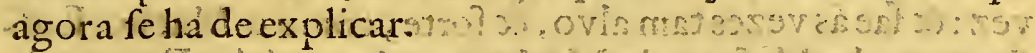

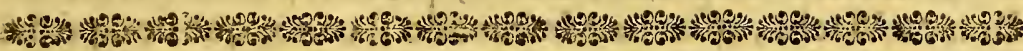

\section{A P T U L O VIII.}

De varias caftas de Affucar, que epardamente $\int_{e}$ encaixao: Marcas das Caixas, Go Jua conducçã ao Irapicbe.

$A$ Ntes de marcar asCaixas, he neceffario fallar de varias A caltas de Affuicar, que feparadamente fe encaixaó; porque tambem nefta Droga ha fua nobreza, ha cafta vil, ha miftura. Ha primeiramente Affucar Branco, \& Mafcavado: - Branco toma efte nome dacor, que tem, \& muito fe lou. va, \& eftima no Affucar, mais admiravel, por quanto fe the communica do barro. O Mafcavado de cor parda he o que fe tira do fundo das Formas, a que chamaó Pés, ou Cabuchos. Do Branco ha fino, ha redondo, \& ha baixo : \& todoseftes faó A Prucares machos O fino hẹ mais alvo, mais fechado, \& de mayor pezo: \& tal he ordinariamente a primeira parte, q́ chamáo Cara da Forma. O redódo he algú tanto menos alvo, \& menos fechado: \& tal he cómummente oda fegunda parte da Forma: \& digo commummente; porq́ naó he efta regra infallivel, podendo acontecer, que a Cara de algumas Formasfeja menosalva, \& menosfechada, que a fegundaparte de outra Forma. Obaixo heainda menos alyo, \& quafitri- 


\section{2}

\section{Cuiltura,}

gueiro na cor: \& aind a que feja bem fechado, \& forte; comtudo, por ter menos alvura, chama-fe baixo, ou inferior.

Alem deftas tres caftas de Brarico, ha outro, que cha. maó Branco Batido, feito do Mel, que efcorreo das For. mas do Macho na Cafa de purgar, cozido, \& batido outra vez : \& fae ás vezes tam alvo, \& forte, como o. Macho. E affim como ha Mafcavado Macho, que he o pé das Formas do Branco Macho; aflim ha Mafcavado Batido, que he o pé das Formas do Branco Batido. O que pinga das Formas do Macho, quando fe purga, chama-fe Mel: \& o que efcorre do Batido Branco, chama-fe Remel. Do Mel huns fazem Agua ardente, eftillando-o: outros o tornaó a cozer, para fazerem Batidos: \& outros o vendem a panellas aos que o eftillaó, ou cozem : \& o mefmo digo do Remel.

Vifta a diverfidade dos Affucares, feguefe fallar das Marcas, que fe haó de pôr com a mefma diftinçaó nas Caix as. Marcaó-fe as Caixas com ferro ardente, ou com trinta : \& tres faó as Marcas, que ha de levar cada Caixa : a faber, a das arrobas, a do Engenho, \& a doSenhor, ou Mercador, por cuja conta fe embarca. A Marca de fogo do numero das arrobas fe poem em cima na cabeça da Caixa, junto ao tampo, começando do canto da banda direita, de tal forte, que abarque juntamente a cabeça da Caixa, \& o tampo. E ifto fe faz, para que, fe depois fe abriffe a Caixa, fe conheça ma is facilmente pelas partes da Marca, que eftaó na cabeça, \& naó correfpondem ás outras partes, que eftaó na borda do tampo.

A Marca do Engenho, tambem de fogo, fe poem na mefma tefta da Caixa, junto a o fundo, no canto da banda direita; para que fe poffaó averiguar as faltas, que poderiaó haver no encaixamento do Aflucar. Porque aflim como ás vézes nas pipas de breo, que vem de Portugal, fe achaó pedras breadas; \& nas peças de panno de linho fino por fóra, no 


\section{EO Opulencia do Brafl.}

meyo fe acha parno de eftopa, ou menor numero de varas', que as que fe apontaó na face da peça :aflim fe poderiaōmádar nas Caixas de Afucar menos arrobas das que fe apontaó na Marca; \& no meyo da Caixa Affucar Mafcavado por Branco, como tem já acontecido, por culpa de algum Caixeiro infiel.

A Marca do Senhor do Affucar, ou do Mercador, por cuja conta fe embarca, fe for de fogo, fe poem no meyo da dita tefta da Caixa; \& re naó for de fogo, poem-fe no mefmo lugar com tinta o feu nome: o qual fe poderá tirarcomhúa enxó, quandofe vendeffe a Caixa a outro Mercador, pondo na dita parte o nome de quem a comprou.

Leva a Marca do Branco Macho hum fó B. o Branco Batidodous BB. O Mafcavado Macho hum M. o Mafcavado Batido hum $M, \&$ hum B. A Marca verbi gratia do Engenho de Serigippe do Conde leva hun S, da Pitanga hum P. E a Marca verbi gratia do Collegio da Companhia de Jefu, leva húa Cruz dentro de hum circulo defa figura. (\$)

$N$ ss Engenhos à beira-mar, levaó-fe as Caixas ao Porto defta forte. Com Rólos, \& Ef peques pafla ố hña atraz de outra da Cafa da Caixaria para húa Carreta, feita para iffo mefmo mais baixa; \& fobre eftafe leva cadácaixa ate o Porto, puxando pelas cordas os Negros de quem a máda embarcar por fua conta.

Dos Engenhos pela Terra dentro, vem cada Caixa fobre hum Carro com tres ou quatro juntaś de Boysi, conforme as lamas, que haó de vencer: \& nifto cufta caro o deficuido; porque por naó as trazerem no tempo do Veraô, depois nó linverno eftazaŏ-fe, \& matáo-feos Boys.

Do Porto paffa fobre taboas groffas a pique para o Barco: \& ao entrar, haó de ter maó nella com focairo, para que naó caya de pancada , \& padeça algum detrimento. No Batco fe haó de airumar as Caixas muito bem, para que vaófe- 


\section{4 \\ ing Cultura,}

guras; nem fe metaó mais, antes menos das que o Barco póde receber, \& levar: \& feja forte, \& bem velejado, \& com Arraes practico das coroas, \& $x$ pedras., \& com Marinheiros naó atordoados da Agua ardente ; fahindo com bom tempo, \& marè.

DoEngenhoaté o Trapiche, ou até a Nao, ém que fe embarca, paga cada Caixa, qưte vem por mar, hüa pataca de frete. Ao entrar, \& fahir do Trapiche, meya pataca. No primeiro mez, quer começado fó, quer acabado, ainda que naó foffem mais que dous dias, paga dous vintens : nos cutros mezes feguintes, hum vintem cada mez. E fe o Trapicheiro, ou o Caixeiro do Trapiche vender por commiffaó do dono algum Affucar, ganha húa pataca por cada Caixa.

E com ifto temos levado o Affucar do Cannaveal, aonde nace, até os Portos do Brafil, donde navega para Portu; gal; para fe repartir por muitas Gidades da Europa. Falta agora dizer alguma coufa dos preços antigos, \& modernos delle; \& das caufas, porque faó hoje tam excellivos.

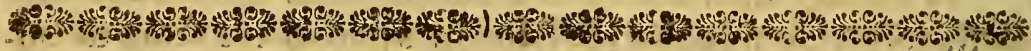 \\ C A P I T U L O IX.}

\section{Dos Pregos antigos, Es modernos do Afjucar.}

D vinte annos a efta parte mudáraó-fe muito os preços affím do Affucar Branco , como do Mafcavado, \& Batido. Porque o Branco Macho, que fe vendia por oito, nove, \& dez toltoens a arroba; fubio depois a doze, quinze, $\&$ dezafeis, \& ultimamente a dezoito, vinte, vinte \& dous, \& vinte \& quatro toftcens; \& depois tornou a dezafeis. . Os Brancos Batidos, que fe largavaó por fete, \& oito toftoens, fubîraó a doze, \& a quatorze. O Mafcavado Macho, que 


\section{\& Opulenciado Brafil.}

95

valia cinco toftoens, vendeo-fe por dez, \& onze, \& aind mais. E o Mafcavado Butido, cuijo preço era hum cruzado; chegou a feis toftoens.

A neceffidade obriga a vender barato, \& a queimar (como dizem ) o Affucar fino, que tanto cufta aos fervos, aos Senhores de Engenho, \& aos Lavradores da Cama, ttibathando, \& gaftando dinheiro. Tambem a falta de Navios, he caufa dé fe naó dar por elle oque val. Mas o ter crecido tanto neftes annos o preço do cobre, ferro, \& panno, \& do mais, de que neçeflitaó os Engenhos; \& particularnente $o$ valor dos Efcravos, que os naô querem largarpor menos de cem mil reis, valendo antes quarenta, \& cincoenta mil reis os melhores; he a principal caufa de haver fubido tanto o Affucar, depois de haver moeda Provincial, \& Nacional, \& depois de defcubertas as Minas de Ouro, que fervîraó para enriquecer a poucos, \& para deftruir a muitos: fendo as me: thores Minas do Brafil os Cannaveaes, \& as Malhadas, em que fe planta o Tabaco.

Se fe attentar para o valor intrinfeco, q́ o Affucar merece ter pela fua mefma bondade; naó ha outra Droga, que o igua1e. E fe tanto fabe a todos. a fuia doçura, quando o comem; naó ha razaó, para que fe llie naó dè talevalor extrinfeco, quando fe compra, \& vende, afim pelos Senhores de Engenho, \& pelos Mercadores, como pelo Magiftrado, a quế pertence ajuftallo; que poffa darpor tanta defpeza algum ganho digno de fer eftimado. Por tanto, fe fe reduzirem os preços das coufas que veni do Reyno, \& dos Efcravos, quie vem de Angola, \& Cofta de Guiné, a húa moderaçaó cont petente; poderáó tambem tornar os Affucảres ao preço moderado de dez, \& doze toftoens: parecendo a todos inipof fivel o poderem continuar de húa, \& outra parte tam dena-

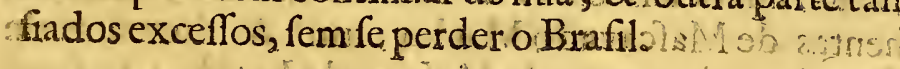




\section{In Culiura,}

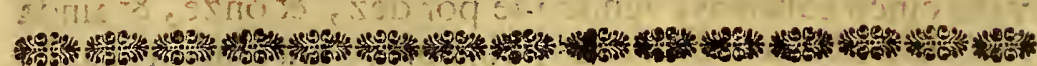

\section{A P I T U L O X.}

Do numero das Caixas de Affucar, que fe fazem cada anno ordinariamente no Brafil.

Ontaó-fe no Territorio da Bahia ao prefente cento \& quarenta \& feis Engenhos de Affucar moentes, \& correntes; alem dos que fe vaófabricando, huns no Reconcavoá beira-mar, \& outros pela Terra dentro, que hoje fá de mayor rendimento. Os de Pernambuco, pofto que menores, chega 0 a duzentos \& quarenta \& feis : \& os do Rio de Janeiro a cento \& trinta \& $\mathrm{x}$ feis.

1.. Fazem-fe hum anno por outro nos Engenhos da Bahia quatorze mil \& quinhếtas Caixas de Affucar. Deftás vaó para o Reyno quatorze mil: a faber, oito mil de Branco Macho, tres milde Mafcavado Macho, mil \& oitocentas de Branco Batido, mil \& duzentas de Mafcavado Batido : \& quinhentas.de varias calftas fe gaftaō na Terra.

As que fe fazem noskingenhos de Pernambuco hum anno por outro, fá doze mil \& trezentas. Vaó doze mil \& cem para o Reyno: a faber, fete mil de Branco Macho, duas mil \& feiscentas de Mácavado Macho, mil \& quatrocentas de Branco Batido; mil \& cem de Mafcavado Batido: \& gaftaófena Terra duzentas de varias caftas.

No Rio de Janeiro fazem-fe hum anno por outro dez milduzentas \& vinte. As dez mil \& cem vaó para o Reyno: a faber, scinco mil \& feiscentas de Branico Macho, duas mil \& quinhentas de Mafcávado Macho, $>$ mill \& duzentás de Branco Batido, oitocentas de Mafcayado Batido : \& ficnó 


\section{É Opulenciado Brafl.}

na Terra cento \& vinte de varias caftas, para o gafto della.

E juntas todas eftas Caixas de Affucar, que fe fazem hum anno por outro no Brafil, vem a fer trinta \& fete mil \& vinte Caixas.

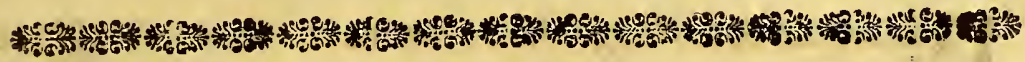

\section{C $\cdot \begin{array}{lllllllllllll} & \text { P } & \text { I } & \text { T } & \text { U } & \text { L } & \text { O } & \text { XI. }\end{array}$}

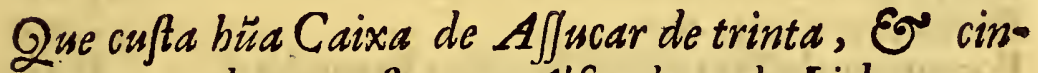
co arrobas, pofta na Alfandega de Lisboa; Eo jà defpachada: Eॅ do valor de todo - Aljucar, que cada anno fe faz. no Brajil.

1 ORol, que fe fegue, conftará primeiramente com exacta diftinçaó o cufto, que faz húa Caixa de Affucar Branco Macho de trinta \& cinco arrobas, defde que fe levanta em qualquer Engenho da Bahia, até fe pòr na Alfandega de Lisboa , \& pela porta della fóra : \& logo o que cufta - húa de Mafcavado Macho, húa de Branco Batido, \& húa de Mafcavado Batido. Em fegundo lugar o Refumo do valor de todo o Affucar, que cada anno fe faz nas fafras da Bahia, Pernambuco, \& Rio de Janeiro.

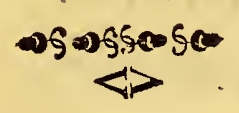

G

Cuftos 
Custos de büa Caixa de A ßsucar Branco Macho de trinta E cinco arrobas.

Plo Caixáóno Engenho ao menos. Por fe levantar o dito Caixaó Por 86 pregos para o dito Caixaó Por 35 arrobas de Affucar a IU600 Por carreto á beira-mar

Por carreto do Porto do Mar atè o Trapiche Por Guindafte no Trapiche

Por entrada no mefmo Trapiche

Por aluguer do mez no dito Trapiche

Por fe botar fóra do Trapiche

Por Direitos do fubfidio da Terra

Por Direito para o Forte do Mar

Por Frete do Navio a $20 \mathrm{U}$

Por defcarga em Lisboa para a Alfandega

Por Guindafte na Ponte da Alfandega

Por fe recolher da Ponte para o Almazem.

Por fe guardar na Alfandega

Por Cafcavel de arquear por cada arco

Por Obras, Taras, \& Marcas

Por Ayaliaçaó; \& Direitos grandes, a 800 reis , \&

a 20 por 100

Por Confulado a 3. por 100

Por Comboy a I 4 o reis por arroba

Por Mayoria

O que tudo importa

IU 200

Uo50

$\mathrm{U}_{320}$

$56 \mathrm{U} 000$

${ }_{2} \mathrm{U} 000$

$\mathrm{U} 320$

Uo80

Uo80

Uo20

UI60

$\mathrm{U}_{300}$

Uo80

IIU 520

U200

Uo40

Uo6o

Uo5o

Uo8o

Uo6o

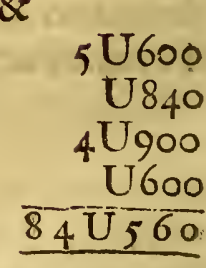

$\infty 550$ 


\section{es Opulencia do Brajl.}

Cuftos de büa Caixa de Affucar Mascavado Macho de trinta \& cinco arrobas.

Por 35 arrobas do dito Affucar a i Uooo reis 35 U000 Por Avaliaçaó, \& Direitos, a 450 reis, \& a 20.por roo $3 \mathrm{U}_{150}$ Por Confulado a 3 por 100

Por todos os mais gaftos

O que tudo importa

$\mathrm{U}_{472}$ $\frac{22 U_{120}}{60 U 742}$

Cuftos de büa Caixa de Affucar Branco Batido de trinta \& cinco arrobas.

Por 35 arrobas do dito Affucar a $\mathbf{I}_{2} 200$ reis Por 35 arrobas do dito Affucar a IU200 reis $42 U_{000}$
Poi Avaliaçaô, \& Direitos; 6 6oo reis, \& a 20 por ioo $4 U_{720}$
Por Confulado a 3. por 100.

Por todos os mais gaftos

Oque tudo importa

$\mathrm{U} 64.8$.

$\frac{22 U_{120}}{69 U}$

Caffos de büa Caixa de Affucar Mafcavado Batido de trinta \& cinco arrobas.

Por 35 arrobas do dito Affucara 640 reis . $\quad{ }_{22} \mathrm{U}_{400}$

- PorAvaliaçaó, \& Direitos,a 300 reis, \& a 20 por 1002 U Ioo Por Confulado a 3 por 100

Por todos os mais gaftos

O que tudo importa

$\mathrm{U}_{315}$

$\begin{array}{r}22 U_{120} \\ 46 U_{935} \\ \hline\end{array}$ 
Calxas de Afucar, que ordinariamente feltiră cad a anño da Babia: \& o que importa o valor dellas a 35 . arrobas.

Por 8000 Caixas de Branco Machoa 84 U560- 6j6480Uoóo Por 3000 Caixas deMafcav. Macho a 60U742- 182226 Uooo Por 1800 Caixas de Branco Batidoa 69U488- $125078 U_{400}$ Por 1200 Caixas deMafcav. Batido a 46U935- 56322 (Fooo Por 500 Caixas, q́ fe gart. na Terra, a 60U200* 30100 Uooo Saó 14500 Caixas : \& importaó$1070206 U_{400}$

Caixas de AJjucar, que ordinariamente fe tira $\vec{o}$ cada anno de Pernambuco: ó o que importao valor dellas a.35.arrobas.

Por 7000 Caixas de Branco Machoa $78 \mathrm{U}_{4220}-548940 \mathrm{U}$ ooo Por 2600 Caixas de Mafcav. Macho a 54 U $500-141700$ Uooo Por 1400 Caixas de Branco Batido a $63 U_{200-} 88480 U_{000}$ Por I 100 Caixas deMafcav:Batido a 39 U800- 43780 Uooo Por 200 Caixas,q́ fe gaft.na Terra, a 56U200- I I 240 Uooo $_{2}$ Saó 12300 Caixas: \& importáó$834140 U 000$

Caixas de Afucar, que ordinariamente Je tirä̌ cada anno do Rio de Faneiro: \& o que importao valor dellas a 35 .arrobas.

Por 5600 Caixas de Branco Macho a $72 \mathrm{U}_{340-} 405$ I04Uooo Por 2500 Caixas de Mafcav. Macho a $48 \mathrm{U}_{2} 20-\mathrm{I} 20550 \mathrm{O} o 00$ Por 1200 Caixas de Branco Batido a 59 U640- 71568 Uooo Por 800 Caixas de Mafcav.Batido a $34 \mathrm{U}_{12} 20-\quad 27296$ Uooo Por 120 Caix. para ogaft.da Terra a $52 \mathrm{U}_{320} \quad 6278 \mathrm{U}_{400}$ Saó $630796 \mathbf{U}_{400}$ 


\section{É Opulencia do Brafil.}

rore

Refumodo que importatodoo Afsucar.

O da Bahia, mil \& fetenta contos,

Yuzentos \& feis mil \& quatrocentos reis--

$O$ de Pernambuco, oitocentos \& $1070206 U_{4}, 00$ trínta \& quatro cótos, cento \& quarenta mill rẹis-

O do Rio de Janeiro, feiscentos \& trinta contos, fetecentos \& noventa \& feis mil \& quatrocentos reis--

Somma todo dous mil quinhentos \& trinta \& cinco contos, cento \& quarenta \& dous mil \& oitocentos reis.

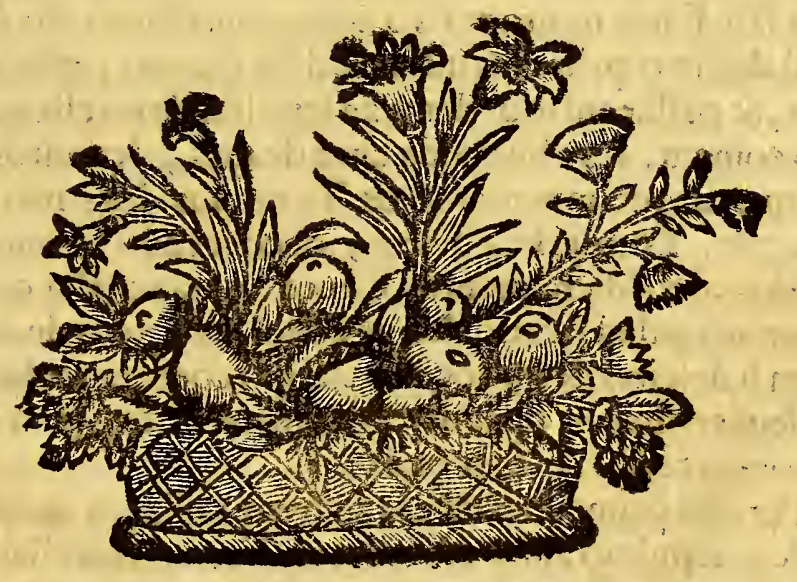

$\mathrm{G}_{3}$

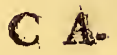




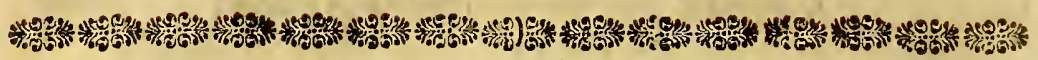

\section{A P I T U L O XII.}

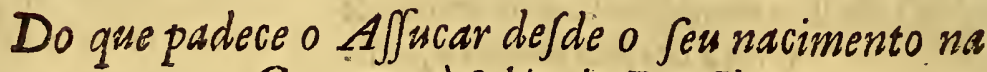 Canna atè Jabir do Brafil.}

$\mathrm{H}$

E reparo fingular dos que contemplaó as coufas naturaes, ver que as que faó de mayor proveito ao genero humano, naó fe reduzem á fua perfeiçaó fem paffarem primeiro por notaveis apertos : \& ifto fe vè bem na Europa no Panno de Linho, no Paó, no Azeite, \& no Vinho, frutos da Terra tam neceffarios, enterrados, arraftados, pizados, efpremidos, \& moîdos antes de chegarem a fer perfeitamente o que faó. E nós muito maiso vemos na fabrica do Affucar, - qual defde o primeiro inftante de fe plantar, atè chegar ás mefas , \& paffar entre os dentes a fepultar-fe no eftomago dos que o comem, leva húa vida chea de taes, \& tantos martyrios, que os que inventáraó os Tyrannos, thes naó ganhaó ventagem. Porque fe a Terra, obedecendo ao imperio do Creador, deo liberalmente a Canna, para regalar com a fua doçura aos paladares dos homés; eftes, defejofos de multiplicar em fi deleites, 8 z goftos, inventáraó contra a mefma Căna, com feus artificios, mais de cem inftrumentos, para lhe multiplicarem tormentos, \& penas.

Por iffo primeiramente fazem em pedaços as que planŁaŏ, \& as fepultaó aflim cortadas na Terra. Mäs ellas tornando logo quafi milagrofamente a refufcitar, que naó padecem 


\section{EO Opulencia do Brafil.}

$\mathrm{IO}_{3}$ dos que as vem fahir com novo alento, \& vigor ? já abocanhadas de varios Animaes; já pizadas das Beftas; jà derrubadas do Vento; \& alfim defcabeçadas, \& cortadas com fouces. Saem do Cannaveal amarradas: \& oh quantas vezes antes de fahirem dahi, faó vendidas! Levaó-fe affim prezas, ou nos Carros, ou nos Barcos àvifta das outras, filhas da mefma Terra, como os Reos, que vaó algemados para a Cadea, ou para o lugar do fupplicio; padecendo em fi confufaó, $z$ dando a mu itos terror. Chegadas à Moenda, com que força, \& aperto, poftas entre os Eyxos, faó obrigadas a dar quanto tem de fuftancia? Com que defprezo fe lançaó feus corpos efmagados, \& defpedaçados ao Mar? Có que impiedade fe queimaó fem compaixaó no bagaço? Arrafta-fe pelas bicas quanto humor fahio de fuas veas, \& quanta fuftancia tinhaố nos offos: tratea-fe, \& fufpende-fe na Guinda: vay a ferver nas Caldeiras, borrifado ( para mayor pena) dos Negros com Decoada: feito quafi lama no Cocho, paffa a fartar as Beftas, $\&$ aos Porcos: fae do Paról efcumando, \& fe lhe imputa a bebedice dos Borrachos. Quantas vezes o vaó virando, \& agitando com Efcumadeiras medonhas? Quantas, depois de paffado por Coadores, o batem com Batedeiras, experimentando elle de Tacha em Tacha o fogo mais vehemente; às vezes quafi queimado; \& às vezes defaffogueado algum tanto, fó para que chegue a padecer mais tormentos? Crecem as bateduras nas Temperas : multiplica-fe a agitaçaó com as Efpatulas : deixa-fe esfriar como morto nas Formas : leva-fe para a Cafa de Purgar, fem terem contra elle hum minimo indicio de crime; \& nella chora furado, \& ferido a fua tam malograda doçura. A qui, daó-lhe com barro na Cara: \& para mayor ludibrio, até as Efcravas lhe botaō fobre o barro fujo as lavagens. Correm fuas lagrimas por tantos rios, quantas faó as bicas, que as recebem : \& tantasfaó ellas, que ba$\mathrm{G}_{4}$

ft:aó 


\section{Cultura,}

ftaó para encher Tanques profundos. Oh crueldade nunca ouvida! As mefmas lagrimas do innocente fe poem a ferver, \& a bater de novo nas Tachas : as mefmas lagrimas fe eftillaóà força de fogoem lambique : \& quando mais chora fua forte, entaó tornaó a darlhe na Cara com barro, \& tornaó as Efcravas a lançarlhe em rofto as lavagens. Sae defta forte do Purgatorio, \& do Carcere, tain alvo, como innocente; \& fobre hum baixo Balcaó fe entrega a outras Mulheres, para que the cortem os pés com facoens: \& eftas naó contentes de Thos cortarem, em companhia de outras Efcravas, armadas de toletes, folgaô de lhe fazer os mefmos pés em migallas: Dahi paffa ao ultimo Theatro dos feus tormentos, que he outro Balcaó mayor, \& mais alto ; aonde expofto a quem o quizer maltratar, experimenta o que póde ofuror de toda a gente fentida, \& enfadada do muito que trabalhou andando atraz delle : \& por iffo partido com quebradores, cortado com facoens, defpedaçado com toletes, arraftado com rotdos, pizado dos pés dos Negros fem compaixaó, farta a crueldade de tantos Algozes, quantos faó os que querem fubir ao Balcaó. Examina-fe por remate na balança do mayor rigor o que péza, depois de feito em migalhas: mas os feus tormentos gravifimos, aflim como naó tem conta, afím naó ha quem poffa baftantemente ponderallos, ou defcrevellos. Cuidava eu, que depois de reduzido elle a efte eftado tam laftimofo, o deixaffem : mas vejo, que fepultado $\mathrm{cm}$ hüa Caixa, naó fe fartaó de o pizar com piloens; nenı de lhe dar na Cara , já feita em pó, com hum pao. Pregaó-no finalmente, \& marcaó com fogo ao fepulcro, em que jaz : \& afim pregado, \& fepultado, torna por muitas vezes a fer vendido, \& revendido, prezo, confifcado, \& arraftado: $\&$ fe livra das prizoens do porto, naó livra das tormentas do Mar, nem do degredo, com impofiçoens, \& tributos : tam feguro de fer 


\section{\& Opulencia do Brafl.}

comprado, \& vendido entre Chriftãos, cono arrifcado a fer levado para Argel entre Mouros. E ainda afim, fempre doce, \& vencedor de amarguras, vay a dar gofto ao paladar dos feus inimigos nos banquetes, faiide nas mézinhas aos Enfermos, \& grandes lucros aos Senhores de Engenho, \& aos Lavradores, que o perfeguíraó , \& aos Mercadores, que o compráraó, \& o leváraó degradado, nos Portos; \& muito mayores emolumentos à Fazenda Real nas Alfandegas.

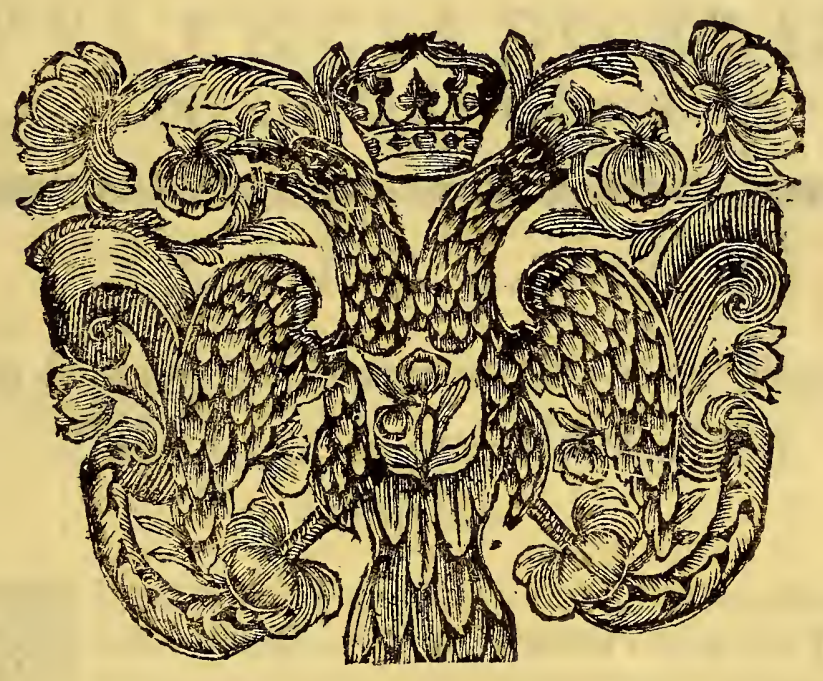

S E. 


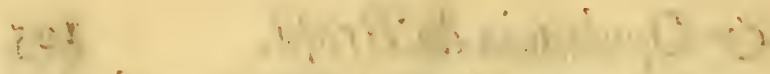

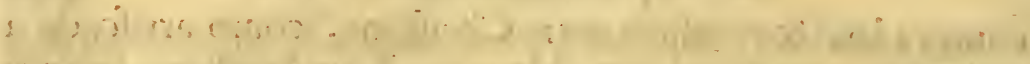

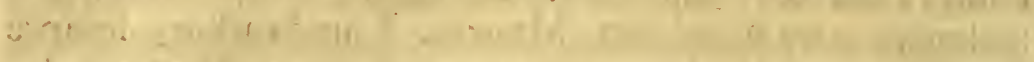

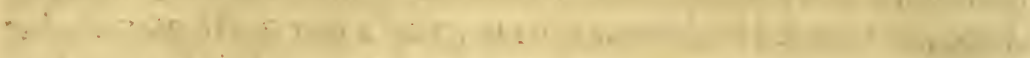

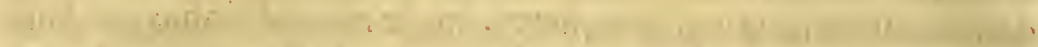

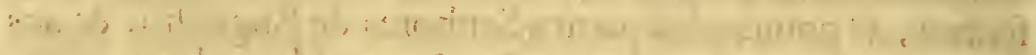

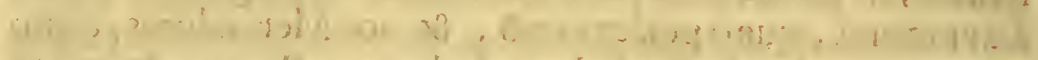
-1.

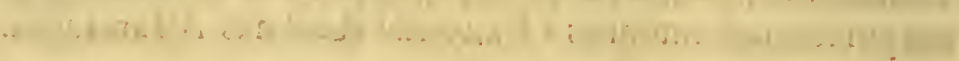

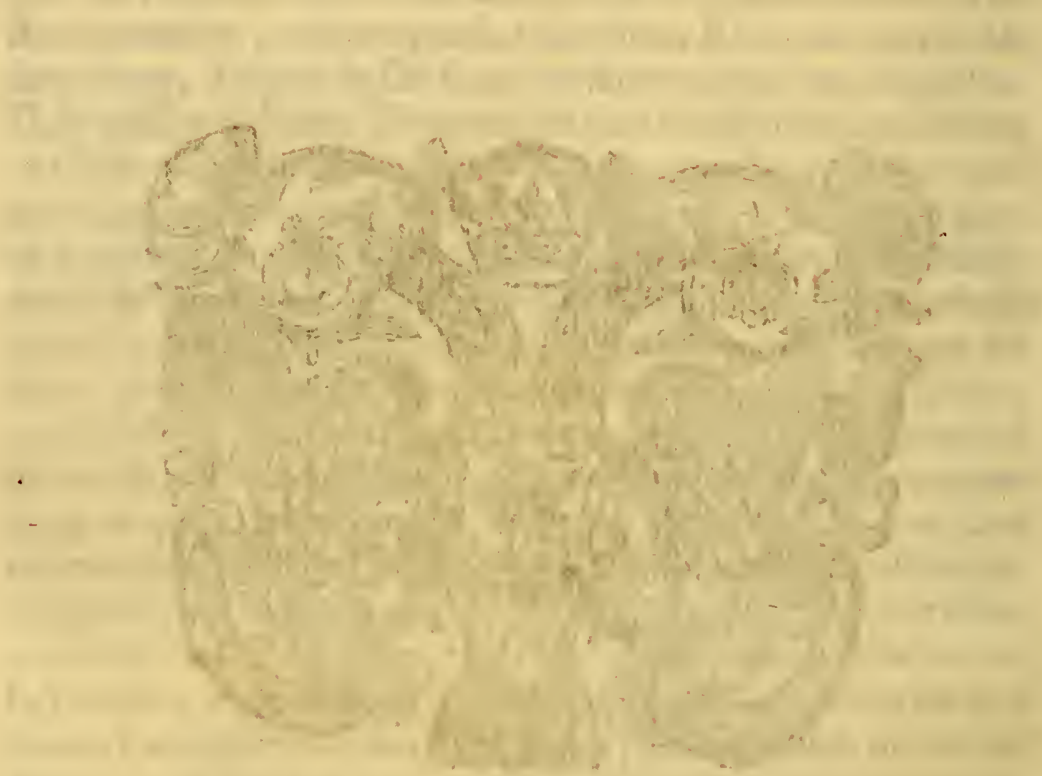

$\therefore ?$ 


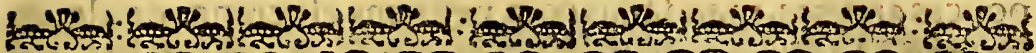

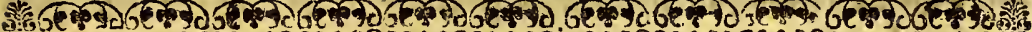
.

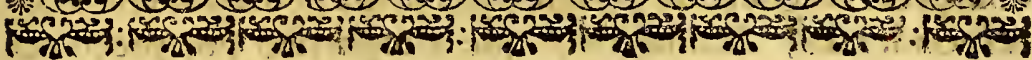

\section{SEGUNDA PARTE. \\ $\mathrm{C}$
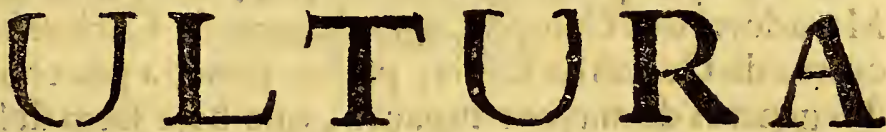 \\ $\mathrm{E}$ \\ O P V L E N C IA DO BRASIL Na Lavra do Tabaco.}

\%

\section{A P I T V L O I.}

Como fe começou a tratar no Brafil da Planta do

$$
\begin{gathered}
\text { Tabaco : of a que estimaçao tem } \\
\text { chegado. }
\end{gathered}
$$

Eva o Aflicar do Brafil o tem dado a conhecer a to. *(1) dos osReynos; \& Provincias da Europa; o Tabaco 2. I oten feito muito mais afamado em todas as qua4ro Partes do Mundo:em as quaes hoje tanto fe defeja, \& có tătas diligêcias, \& por qualquer via fe procura. $\mathrm{Ha}$ pouco mais de cem annos, que efta folha fe começou a plantar, \& beneficiar na Bahia: \& vendo o primeiro, que a plantou, o lucro, pofto que moderado, que entaó lhe deraó hías 
poucas arrobas, mandadas com pequena efperança de algum retorno a Lisboa, animoulfe a plantar mais : naê tanto por cobiça de Negociante, quanto por fe lhe pedir dos feus correfpondentes, \& amigos, que a repartiaó por preço accommodado, porém já mais levantado. Atè que imitado dos vizinhogs, que com ambiçaố a plantảraổ, \& enviàraó ent mayor quantidade: \& depois, de grande parte dos. Moradores dos Campós, que chamaó da Cachoeira, \& de outros do Certaó da Bahia ; pafiou pouco a pouco a fer hum dos generos de mayor eftimaçắ, que hoje faem defta $A$ merica Meridional para o Reyno de Portugal, \& para os outros Reynos, \& Republicas de Naçốes eftranhas. E defta forte hria follha antes delprezada, \& quafi defconhecida, tem dado, \& dà actualmente grandes cabedaes aos Moradores do Brafil, \& incriveis emolumentos aos Erarios dos Principes. Defta pois fallaremos agora, moftrando primeiramente comofe femea, \& planta: comofe alimpa, \& colhe : como fe beneficia, \& cura: como fe enrola, \& fe defpacha na Alfandega. 2. Como fe piza, \& fe lhe dà o cheiro: qual he melhor para fe maffar ; qual para o cachimbo; \& qual para fe pizar: \& fe o granido, ou o em pó. 3. Doufo moderado delle para a faude; \& do immoderado, \& viçiofo na quantidade, no lugar , \& no tempo. 4. Dos Rolos, que cada anno ordinariamente fe embarcaô doBrafil para Portugal: do valor delle na Bahia, \& no Reyno: das penas para fe naó mandar, on introduzir fem defpacho: \& dos artificios para fe paffar de contrabando, naó obitante a vigilancia dos Guardas, aflim dentro; como fóra de Portugal. E frnalmente do rendimento defte Contrato, \& dar repartiçaó do Tabaco por todas as partes do Mundo. Tudo conforme as noticias certas, que procurey, \& me deraỏ os mais intelligentes, \& mais verfados nefta lavra; ;as quaes no que direy, me reporto. 


\section{¿o Opulencia do Brafal.}

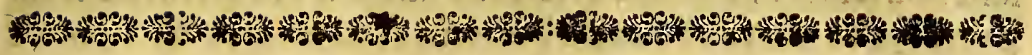

\section{A P I T U L O II.}

Em que confifte a Lavra do Tabaco: Eo de como $\sqrt{e}$ Semea, planta, $\sigma^{\circ}$ alimpa: $\sigma^{\circ}$ em que tempo. Se ba de plantir.

7 Oda a lavra, \& cultura do Tabaco confifte por fua or1 dem em fe femcar, plantar, alimpar, capar, defolhar, colher, efpinicar, torcer, virar, ajuntar, enrolar, encourar, \& pizar: \& de tudo ifto iremos fallando nos Capitulos feguintes. E começando nefte pela planta : femea-ie efta em caritelros bem eftercados; ou em queimadas feitas no matto, aonde ha terra conveniente para iffo, \&r aparellradas no meímo, anno, em que fe ha de femear. O tempo, em que commummente fe femea, faŏ os mezes de Mayo, Junho, \& Julho: \& depois de nacida a femente, nace tambem com ella algum capim; o qual fe tira com tento, que fé naó arranque por defcuido com o capim viciofo a planta innocente.

Tendo a plantajà hum palmo, ou pouco menos de altura, fe paffa dos canteiros, aonde naceo, para os cercados, ou curraes, aonde fe ha de criar: cuja terra quanto mais eftercada, he melhor. Mas fe nos ditos curraes morou por muito tempao Gado ; ha-fe de tirar antes alguma parte do efterco, para que a força delle, ainda naó cortido do tempo, naó queime a planta, em vez de a ajudar.

Diftribue-fe a dita terra em regos com rifcador, para que a planta fique viftofa. A diftancia de hum rego de outro he de cinco palmos : \& a das plantas entre fi he de dous palmos \& meyo, para que fe poffaó eftender, \& crecer folgadamente; fers: 
fem húa fer de embaraço à outra. Planta-fe em covas de hum palino, quanto cava a enxada metida, \& eftas fe enchem de terra bem eftercada : \& com vigilancia, \& cuidado fe corre a dita planta todos os dias, para ver fé tem Làgarta ; \& efta logo fe mata, para a naó comer, fendo tenra. Os inimigos da ptanta faó ordinariamente, alem da Lagarta, a Formigy, o Pulgaó, \&r o Grillo. A Lagarta em pequena corta-lhe o pé, ou raiz debaixo da terra; \& em crecendo, cortalhe as follhas. O mefmo faz tambem a Formiga: \& por iffo fe poem nos regos, aonde efta apparece, outras folhas de mandiôca, ou de aroeira; para que dellas coinaó as Formigas; $\& x$ naó cheguein a cortar, \& comer as do Tabaco, que fendo cortadas defta forte naólervem. O Pulgaó, que he hum Mofquito preto, pouco mayor que húa Pulga, faz buracos nas folkas; $\&$ rettas a fim furadas, naó preftaó para fe fazer dellas torcidà. $O$ Grillo, em quanto a planta he pequena, a corta rente da terra; \& fendo jà crecida;, taimbem fe atreve a cortarlhe as folhas.

Sendo jà a folha baftantemente crecida, fe lhe chega so pé aquella terra, que fe tirou das covas em que foy plantada, daquella parte, que ficou arrumada mais alta :. porèm em tempo de Inverno naó fe aperta muito; porque todá eftâ hunìida: no Veraó aperta-fe mais, para que a terra a defenda; \&ra humidade, pofto que mencr, the dè o primeiro alimento. Eifto faz quem a planta.

Eftando a planta em fua conta, com oito, ou nove folhas, conforme a força, com que vem crecendo, fe the tira o olho de cima, on grello, antes de efpigar : o que por outra frafe chamaó capar. E porque faltando-lhe efte olho, nace em cadapé das follhas outro ollho; todos eftes olhos fe haó de botar fóra, (\& a iifto chamaŏ defolhar) para q́ naô tirem a fuftancia às fólhas: E efta diligécia fe faz peló menos de oito em oito dias: \& mais frequentemente fe vifitaó, \& correm os regos, 


\section{EO Opulencia doBrafil.}

para tiraro capim, atè eftarem as folhas fazonadas : o que fe conhece por apparecerem nellas húas nodoas amarellas ; ' ou por eftar jà preto por dentro o pè da folha, o que comnummente fuccede ao quarto mez depois de poftas em fuas covas as plantas.

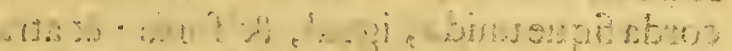

ข

\section{A P I $T$ U $L$ O III.}

Como Je tira $\breve{o}, \mathcal{E}$ cura $\overrightarrow{0}$ as folbas do Tabaco: como dellas se fazem, Er beneficiao as

cordas.

Q Uebraó-fe as folhas rente da haftia com o talo, \& juntasem cafa fe deixaó eftar afim por vinte $8 x$ quatro horas, pouco mais, ou menos : \& logo antes de fe efquentarem, \&r feccarem, fe dependuraó duas \& $\mathrm{x}$ duas pelo pè, metidas entre a paltha (de que contaó as cafas, em que fe beneficiaó) \&ras varas; ou em outra parte, aonde lhes dè o vento, mas lhes naó chegue o Sol : porque fe efte lhes chegaffe, logo fe feccariaó, \& perderiaó a fuftancia. E tanto que eftiverem enxutas em fua conta, que pouco mais ou menos ferá depois de eftarem affim dependuradas dous dias; fe botaó no chaó, \& fellhes tira a mayor parte do talo pela parte inferior, con o devido cuidado, para q́ fe naó rafguem com o defvio do talo: $\&$ a ifto chamaó efpinicar. E entaó fe dobraó pelo meyo as melhores, q́ haó de fervir de capa para a corda, que fę ha de fazer de todas as mais folhas. E advirta-fe, que as folhas, que fe tiráraó em hum dia, naó fe haô de mifturą fenaó com as que fe tirarem no dia feguinte; para que fejaố 
igualmente fazonadas : \& fe naô forem affim, hũas prejudicaráó ao bom concerto das outras.

Curadas as folhas, \& tirado já o talo como eftá dito; dellas fe faz húa corda da groffura quafi de tres dedos. E para iffo haverá Roda, \& hum Torcedor entendido, para que a corda fique unida, igual, \& forte : \& atraz delle eftará outro colhendo a torcida fobre hum pao, ou fobre o aparelho, como qualquer outra corda fimples, \& naó como as que fe fazem de cordoés : \& junto do' Torcedor vaó os Rapazes, que daó as folhas para fe torcerem em corda.

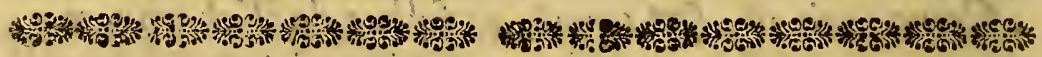

\section{A P I T U L O IV.}

Como se cura o Tabaco depois de torcido em corda.

14 Eita a corda docomprimento, que quizerem, \& enro14 dilhada em hum pao;fe defenrola cada dia, a faber, pela manhaã, \& á noyte, \& paffa-fea outro pao, para que naó arda: \& na paffagem fe vay torcendo, \& apertando branda- . mente, para que fique bem ligada, \& dura. E tanto que ficar preta, vira-fe fó hüa vez cada dia : \& como fe vayaperfeiçoando, fe diminuem as viraduras; atè ficar em eftado, que fe poffa recolher fem temor de que àodreça. E commummente efte beneficio coftuma durar quinze, ou vinte dias, cóforme vayo tempo, mais ou menos humido, ou fecco.

Segue-fe atraz diffo o que chamaó ajuntar, que vem a fer, pôr tres bollas de corda de Tabaco em hum pao, aondefica, atè que chegue o tempo de enrolar. Eentre tanto guardaó-feeftas bollas no Tendal, que he como hum andai- 


\section{Es Opulencia do Brafll.}

mealto, com feus regosem baixo, para receberem a calda, que botaốdefi effas bollas; \& efta fe ajunta, \& guarda s paradepois ufar della, quando for tempo de enrolar.

O ultimo beneficio, quefe lhe faz, he ofeguinte. Tem. pera-fe a caldia do mefmo, Tabaco com feus cheiros de herva doce, alfavaca, \& manteiga de porco: \& quem faz mano. jos de encomenda, botalhe almifcar, ou ambar, fe o tem: 8 . por efta calda mifturada com mel de affucar ( quanto mais groflo, melhor) fe paffa a mefma corda de Tabaco hũa vez: \& logo fe fazem os Rolos do modo feguinte:

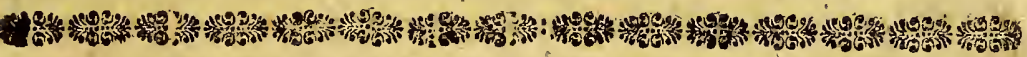

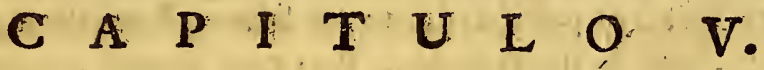

Como fe enrola, Es encoura o Tabaco: Eั que PejJoas se occupaõ en toda a fabrica delle, defde a fua planta atè fe enrolar.

D Ara enrolaro Tabaco, dobraó a cordajá curada \& nîelada, de comprimento de tres palmos; fobre húa eftacis. naó muito groffa, \&z: leve, que nas extremidades tem quatro taboinhas em cruz: fobre as quaes dobrada, \& fegurada de húa \& outra parte a dita corda, fe vay enrolando atè o fim: puxando fempre bem, \& unindo húa dobra com outra; de forte, que naó fique vaó algum entre as dobras. E para $́$ as cabeças fiquem fempre direitas; alem das cruzetas; que levaó; Thes vaō metendo follhas de Urucurì nos yãos, para que fiquem bem unidas com as dobras de dentro.

Acabado o Rolo, fe cobre primeiramente com follhas de Caravatá feccas, amarradas có embîra; \& depois fe lhe faz hũa: cappa de couro da medida do rolo: a qual cofida, \& apertas H da 


\section{Cultura;}

da muito bem, marca-fe com a marca do feu dono. E defta forte vaó os Rolos por terra em carros, \& por mar em barcos, a ferem defpachados na Alfandega, antes de fe meterem nas Naós: E cada Rolo péza commummente oito arrobas.

Vindo agora a fallar das Peffoas, que fooccupaóna fabrica, \& cultura do Tabaco; ella he tal, que a rodos dá que fazer : porque nella trabalhaó grandes, \& pequenos; homés, \& mulheres; Feitores ; \& fervos. Mas nem todos fervem para qualquer minifterio dos que acima ficaó referidos. Para fe. mear, \& plantar a folla, he neceffario, que feja peffoa, que entenda diffo, para que fe guarde bem o modo, a direitura, \& a diffancia affim dos regos, comodas covas. O cavar as covas pertence aos que andaó no ferviço com a enxada: os Rapazes botaổos pés da planta, a faber, hum em çada hũa das covas, que jà ficaó feitas. E o que planta, apertalhe a terra a pé, mais ou menos, conforme a humidade della. Toda a Gente fe occupa em catar a Lagarta duas vezes no dia, a faber, pela madiugada, \& depois de eftar of fol pofto: pórque de dia eftá débaixo da terra; \& ofinal de eftar a hi, he o acharfe algúa folha cortada de noite. Chegarlhe a terra com a enxa$\mathrm{da}$, he trabalho dos granđes. Capar a planta jà crecida, ifto he, tirarlhe ollho, ou grello na ponta da haftia; he officio de Negros Meftres. Defolhar; que vem a fer, tirar os outros olhos, que nacem entre cada folha, \& a haftia; fazem pequenos, \& grandes. A panhar, ou colher as folhas, he de quem fabe conhecer quando he tempo, pelofinal, que tem a folha, ande fe pega com a haftia, que heo fer ahi de cor preta. Toda a Gente de ferviço fe occupa em dependurar as follias nos: altos: \& ifto fe faz commummente de noite. Pinicar, ou efpinicar, ou efpicar, que tudo he o mefmo, \& vem a fer, tirar o talo às folhas do Tabaco; he trabalho leve de pequenos, \& grandes. Torcer as folhas fazendo dellas corda, encomendaLe a algum NegroMeftre: \& o que anda com a Roda, ouEn!.

genlio 


\section{¿o Opulencia do Braßi.}

genho de torcer, ha de fer Negro robufto : \& tambem botar a cappa á corda, para que fique bem redonda, he obra de Negro experimentado. Os.Rapazes daŏ ao Torcedor as foThas, \& tambem as cappas ao que vay cobrindo com as me. Thores a corda : \& o mefmo que bota as cappas, he o que enrola: O paffar as cordas de hum pao para outro, corre por conta de dous-Negros: dos quitaes hum eftà no virador, \& oultro vay defandando a corda enrolada no pao. Os que viraó, ou mudaó a corda de hum pao para outro; faó Negros Meftres; \& em cada virador faó neceflarios tres : hum ; que largue a corda; outro; que a colli; \& outro, quie ande no virador. Ajuntar, que he pôr a corda de tres bollas em hum pao; he obra dos Negros mais deftros: \& faó tries; \& às vezes quatro; porque naó bafta hum fó no virador, mas ha mifter dous, psra que apertem bem a corda. Enrolar finalmente, he occupa. çaô de bons Officiaes. para que fique a obra fegura:

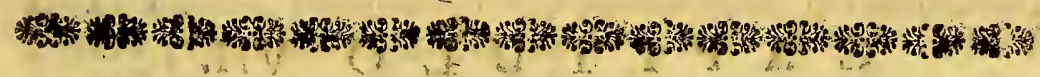

\section{A P I U L O VI.}

- Da jegunda, E terceira folha do Tabaco: E de diverfas qualidades delle, para $f e$ maf. car, cacbinabar, Eo pizar.

7 Vdooque eftá dito atéaqui do $T$ abaco, que chamaố da primeira follha, \& valo mefmo, quéo da primeira coltheita; fe ha de entender tambem do da fegunda, \& terceira folha; fe a Terra ajudar para tanto; $\&$ for para iffo ajudada com o beneficio do tempo, \& do efterco. Por tanto tiradas todas as primeiras folhas, corta-fea haftia menos de hum $\mathrm{H} z$ pal:- 
palmo fobre a Terra, para que brote as fegundas : \& crecen: do ellas, fellhes tiraó (como eftà dito acima) os olhos do tronco, \& ocapim dos regos: \& o mefmo beneficio, que fe fez às primeiras folhas, fe faz às da fegunda colheita. E fea Terra for forte, faz-fe a terceira, \& multiplicâó-fe os R olos.

O Tabaco da primeira fol ha heo melhor, o mais forte, \& o que mais dura: \& efte ferve para ocachimbo, \& parafe mafcar, \& pizar. O fraco, para fe mafcar naó ferve; \& fó prefta para fe beber norachimbo. Os que oquizerem pizar, haó de ajuntar ao melhoraquelles talcs, q́ fe tiraó das fol has, depois d e eftarem bem feccos: porque eftes pizados com as folhas fazem ao Tabaco forte, \& de boacor. E para o Tabacoem pó, o das Alagoas de Pernambuco, \& o dos Campos da.Cachoeira, \& das Capivâras, he o melhor.

\section{A P I T U L O VII. \\ Como fe piza o Tabaco: do Granido, Eo empó; Go como se lhe da o cheiro.}

D Ara fe pizar o Tabaco, ha de fer bem fecco, ou ao Sol, 1 ou em bacias, ou fornos de cobre, comattençaó para quefe naó queine; \& porifo fe ha de mexer continuamen: te: $8 r$ os piloens, em que fe piza, haó de fer de pedra marmore, com as mãos de pizar de pao. Pizado, peneira-fe: \& o que eftiver capaz, fe tira á parte; \&ro mais groffo fe torna a pizar, atéfe reduzir em pó. E efte he oque commummente mais fe procura, \& fe eftima.

Do Granido fe ufa muito em Italia : \& faz-fe defta forte. Toina-fe o Tabacojá feito em pó, \& poem-fe em hum alguidar 


\section{É Opulencia do Brafil.}

dar vidrado : botafe-lhe em quantidade moderada algum mel ; ou calda de Tabaco; \& fe efta for muito groffa, fe fará liquida com hum pouco de vinho. Depois; para que fe vá encorporando, fe mexe muito ben, \& mexido fe levanta, \& menea-fe entre as máos, como quem faz bolinhos: \& eftandoaffiın humido, fe paffa por húa oropêma fina : \& nefta pâflagem pelos buraquinhos da oropêma fe formaó os granitos, como os da polvora fina ; \& fica o Tabaco granido. E o que naố pafla pela oropêma, por fer ainda groffo, torna-fe a menear, como eftá dito, entre as máos, atè fer capaz de parfar. Paffado, fe fécca a o Sol fem fe mexer; para que naó torne a amaffar-fe; \& perca o fer de granido.

Depois de o Tabaco granido eftar fecco, fe lhe quizerem dar algum cheiro, borrifi-fe com agua cheirofa: ou poem-fe: no mefmo vafo, em quefe recolheo, hũa vainilha inteira, ou. alguma quantidade de ambar, ou de algalia, ou de almifcar. Porèm o Tabacoem pò naó he capáz de fer borrifado com: agua cheirofa; porque com ella fe amaffaria, \& naố ficaria comofe pretendeo, foltoem pó.

O Tabaco, que fe piza no Brafil, vay fem miftura, fingelo , \& legitimo em tudo; \& por iffo tanto fe eftima. Maso que fe piza em algumas partes da Europa, vende-fe tam vi- ciado, que apenas merece o nome de Tabaco; pois com elle atè as cafcas de laranjas fe pizaó.

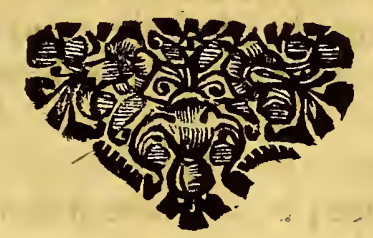

$$
\mathrm{H}_{3} \quad \mathrm{CA} \text { - }
$$




\section{8}

\section{Cultura,}

\section{A P I U L O VIII.}

Do uso moderado do Tabaco para a faude: Eo da demafia nociva a mesma saude, de qual= quer modo que je ufe delle.

S que faó demafiadamente affeiçoados ao Tabaco, o chamaōHerva fanta: nem ha epitheto de louvor,que The naô dem, para deféder o exceffo digno de reprehenfaó, \& de nota. Homens ha, que parece naó podem viver fem efte quinto elemento; cachimbando a qualquer hora $\mathrm{em}$ cafa, \& nos caminhos; mafcando as fuas fothas, ufando de torcidas, \& enchendo os narizes defie pó. E efta demafia naó fómente fe vè nos Maritimos, \& nos trabalhadores de qualquer cafta, forros, \& Efcravos, os quaes eftaô perfuadidos, que fó com Tabaco haó de ter alento, \& vigor; mas tambem em muitas Peffoas nobres, \& ociofas; nos foldados dentro do corpo da guarda ; \& em naó poucos Ecclefiafticos Clerigos, \& Religiofos:na opiniaó dos quaes toda effa demafia fe defende, ainda quando fe vè manifeftamente, q́fe naó ufa por mézinha, mas por dar gofto a hum exceffivo, \& mal habituado prurito. Eu, que de nenhum modo ufo delle, ouvi dizer, que o fumo do cachimbo, bebido pela nuanhaá em jejum moderadamente, deffeca as humidades doeftomago ; ajuda para a digeftaó. \& naó menos para a evacuaçaó ordinaria; alivia ao peito, que padece fluxaó afmatica; \& diminue a dor infoportavel dos dentes.

O mafcallo naó he tam fadio : porém aflim como mậca 


\section{Es Opulencia do Biafil.}

do peia maniáa em jejum moderadamente, ferve para deffecir a abundancia dos humores do eftomago; afim o ufo immoderado o relaxa: \& pela continuaçaó obra menos, altera o gofto, faz grave o bafo, negros os dentes, \& deixa os beiços immundos.

Vfaó algưns de torcidas dentro dos narizes, para purgar por elta via a cabeça, \& para divertir oeftillicidio, que vay a cahir nas gengivas, \& caufa dores de dentes : \& poftas pela manhãa, \& à noite, naó deixaó de fer de proveito. Só fe encommenda aos que ufaó dellas, o evitarem a indecencia, que caufa o apparecer com ellas fóra dos narizes, \& com húa gotta deeftillicidio fempre manante, que fuja a barba, \& càna nojo a quem com elles converfa.

Sendo o Tabaco em pó o mais ufado, he certamente o menos fadio : aflim pela demafia, com que fe toma, que paf: fa de mézinha a fer vicio; como por impedir o mefmo contume exceffivo os bons effeitos, que fe pertendem, \& que tal vez caufaria, feo ufo foffe mais moderado. Deixando po: rém de reparar nefta viciofa fuperfluidade, fó lembro quan:to dous Summos Pontifices Vrbano VIII. \& Innocencio X eftranháraó o ufar delle nas Igrejas, pela grande indecencia,: que reparâraó; \& julgâraó ter efte intoleravel abufo, dıgno de fe notar, \& eftranhar nos Seculares, \& mais nos Ecclefiafticos pouco acautelados ainda quando affiftem no Coro aos Offi cios divinos; \& muito mais nos Religiofos, que devem dat exemplo a todos ( $\&$ mayormente nos lugares fagrados) de gravidade, \& modettia. E por iffo ambos os fobreditos Pon tifices chegâraó a prohibillo com excommunhaó mayor : o primeiro com hum Breve de 30. de Janeiro do anno 1642. 0 prohibio na Igreja de Saó Pedro em Roma, \& no adro, \& alpendre do dito Templo : o fegundo com outro Breve debaixo da mefma pena aos 8. de Janeiro de I650.nas Igrejas de odo hum Arcebifpado, em que fe hia introduzindo efta de$\mathrm{H}_{4} \quad \mathrm{mafia}$ 
mafia com efcandalo. E em algumas Religicens mais obfervantes fe prohibio o ufo publico do Tabaco nas Igrejas com privaçaó de voz activa, \& paffiva, ifto he, fob pena de ná́ poderem fer eleitos os transgreffores, nem poderem efcolher a outros para Superiores, \& para outros officios da Ordem.

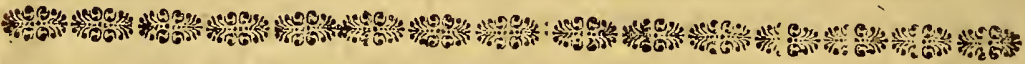

\section{$\begin{array}{llllllllll}C & A & P & I & T & U & L & O & I X .\end{array}$}

\section{Do modo com que se despacha o Tabaco na Alfane dega da Babia.}

13 Eneficiado, \& enrolado o Tabaco, \& pago ofeu dizi1 moa Deos, que he de vinte arrobas hủa: ( $\&$ rende efte dizimo hum anno por outro dezoito mil cruzados, como confta do arrendamento do dizimo, que fe tira da Cachoeira da Bahia , \& fuas Fréguezias annexas ; fóra o que fe lavra pelas mais partes do Certaó della em Serigippe de ElRey, Cotinguîba, Rio Real, Inhambûpe, Montegordo, \& Torre, que apartado do rendimento do dizimo do Affucar, \& mais meunças, rende dez atè doze mil cruzados) vem pagando feus carretos, \& fretes para a Cidade da Bahia, atè fe meter em húa fua propria Alfandega, aonde fe defpachaó para Lisboa, hum anno por outro, de vinte \& cinco mil Rolos para cinı: os quaes pagaó por hum Contrato da Camera; a fetenta reis por cada Rolo; \& deftes tem El-Rey a terceira parte: \& as duas faó para o Prefidio da mefma Cidade, que importaó cinco mil cruzados.

Pagaó mais a húa balança a tres reis por arroba, que a Camera arrenda na mefma forma já dita, \& importa mil \&. duzentos cruzados. 


\section{é Opulencia doBrafil.}

121

Defte Tabaco fe permitte a extracçaó de treze mil arro. bas, para a navega çaố d: Cofta da Mina, que fe arrumaó em cinco mil Rolos pequenos de tres arrobas : os quaes tambem pagaó a letenta reis por cada Rolo para o fobredito Contrato da Camera, \& importa mil cruzados.

Defátreze mil arrobas fe pagaó por dizimo a El-Rey quatro vintens por arroba, \& pagaó-fe na $\mathrm{Cafa}$ dos Contos: o que im porta tres mil cruzados.

Váó para o Rio de Janeiro todos os annos, tres mil arro. bas : as quaes nada pagaó na Bahia; mas vaó a pagar no dito Rio de Janeiro vinte \& cinco mil cruzados cada anno por Contrato de El-Rey, o qual pouco mais ou menos por tanto fe arrenda.

E tudo o que nefte Capitulo do defpacho do Tabacoeftá dito, importafeffenta \& cinco mil \& dizentos Cruzados.

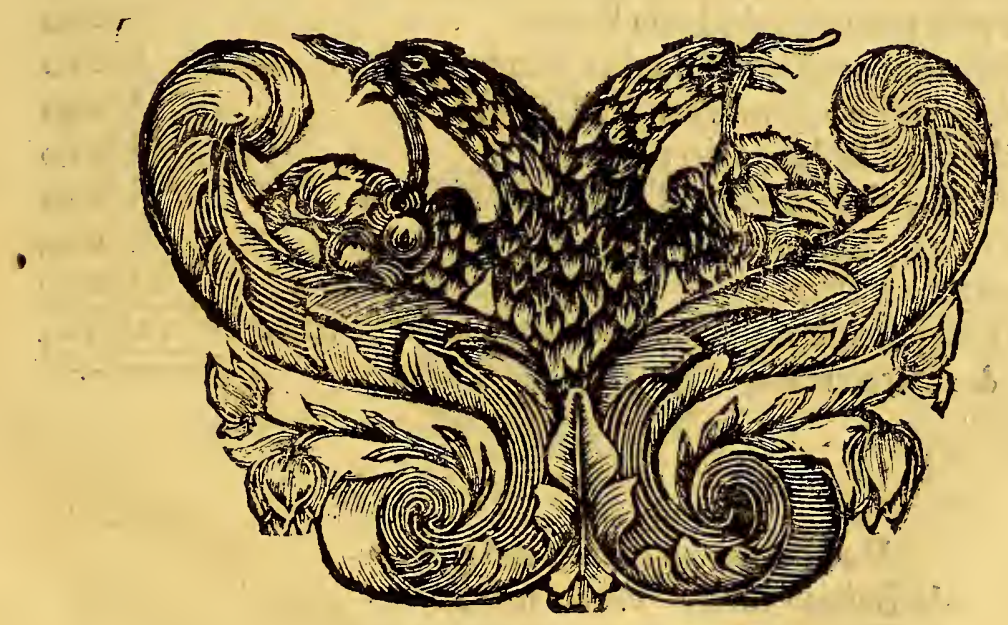

C A. 


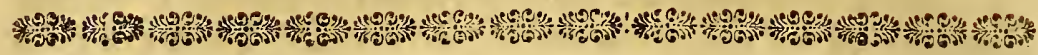

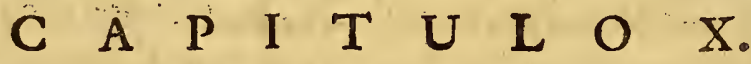

Que cuifta bum Rolo de Tabaco de oito arrobas pofto da Babia na Alfandega de Lisboa, Eo jà. despachado, Eั corrente para

Jabir dellia.
$\mathbf{O}$
Rolodo Tabaco
O couro, \& o enrolallo nelle
C) Frete para o Porto da Cachoeira
O Aluguer no Almazem da Cachoeira
O Frete para a Cidade da Bahia
A defcarga no Almazem da Cidade
O Aluguer nó Almazem da Cidade
O chegar á Balança do pezo
O pezar a dez reis por Rolo, \& botar fóra
O Pezo da Balança, a tres reis por arroba
Direitos, \& Fretes, \& maisgaitos em Lisboa
O que tudo importa doze mil cento \& vinte \& quatroreis-
$8 \mathrm{U} 000$
' $\mathrm{U}_{300}$
$\mathrm{U} 550^{\circ}$
Uo4.
Uo80
Uo20
$\mathrm{U}_{4} \mathrm{O}$
Uoro
Uolo
Uo24,
$\frac{2 \mathrm{U} 050}{12 \mathrm{UI} 24}$

\section{Vaô ordinariamente cada anno} da Bahia vinte \& cinco mil Rolos de Tabaco: \& a dóze mil cento \& 


\section{\& Opulencia do Bra/ll.}

vinte \& quatroreis, importaó trezentos \& tres contos \& cem mil. reis

Vaóordinariamente cada anno $303 \cdot 100 \mathrm{U} 000$ das Alagoas de Pernambuco dous mil \& quinhêtos Rolos : \& a dezafeis mil feiscentos \& vinte reis, por fer melhor o Tabaco, importaó quarenta \& hum contos, quinhentos \& cincoenta mil reis--

Importa todo efte Tabaco trezentos \& quarenta \& quatro contos, feiscentos \& cincoenta mil reis--

E reduzidos a cruzados, faó oito cétos \&dfeffenta \& hum mil,feiscentos \& vinte \& cinco cruzados.

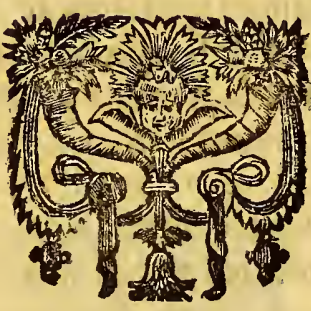


124

\section{Cultura,}

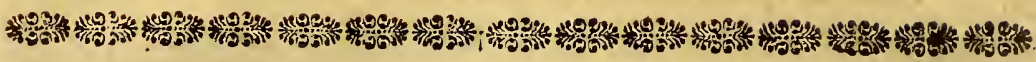

\section{A P I $\quad T$ U L O XI.}

Da estimaçắ do Tabaco do Brafil na Europa; Eo nas mais partes do Mundo: Eூ dos gran=. des emolumentos, que delle tira a Fazenda Real.

7. Oque atéagora fe tem dito, facilmente fe pódeentender a êlimaçaó, \& valor a que tem chegado o Tabaco, \& mais particularmente o do Brafil. Pois (como diffe ao principio) havendo pouco mais de cem annos, quefe começou a plantar, \& beneficiar na Bahia ; foraó as primeiras arrobas, que fe mandâraó a Lisboa, como hứa fementeira de defejos, para que cada anno fe pediffem logo, \& fe mandaffem mais, \& mais arrobas. E paffando de mimo a fer mercancia; hoje apenas os tantos milhares de Rolos, que levaó as frotas, faóbaftantes para fatisfazer ao appetite de todas as Naçoens, naó fómente da Europa, mas tambem das outras partes do Mundo, donde encarecidamente fe procuraó. Val hŭa livra de $T$ abaco pizado em $L$ isbon de vinte atè vinte \& quatro toftoens, conforme he mais, ou menos fino: \& o que El-Rey tira defte Contrato cada anno, faó dous milhoens, \& duzentos mil cruzados. Nem hoje tem os Principes da Europa Contrato de mayor rendimento, pela muita quantidade de Tabaco, que fe gafta em todas as Cidades, \& Villas.

Sirva de prova o que conta Engelgrave no primeiro Tomo da Luz Evangelica, na Dominga quinta depois do Pentecolte ao 5 . I. allegando por teftimunho do que diz ao Hi-

ftoria- 


\section{GOpulencia do Brifa.}

125

ftoriador Barnabè de RijcKe, comocertamente informado. Diz pois efte Author, que na Cidade de Londres, Cabeça da Gram Bretanha, povoada de mais de oitocentas mil Almas, paffaó as vendas do Tabaco o numero de fete mil o \& dando, que cada húa deftas naó venda mais cada dia, que hum forim \& meyo de Tabaco; importarà o que fe vende cada dia , dez mil \& quinhentos florins : os quies reduzidos á moeda Portigueza, em que cada florim fá dous toltoens, importaó cinco mili \& duzentos \& cincoenta cruzados E confequentemente o que fe rende fó en Londres em hum anno, que confta de trezetos \& feffenta \& cinco dias, importa hum milhaó, novecentos \& dezafeis mil, duzentos \& cincoenta cruzados. Ea que fomma chegará o que fe vende cada anno em toda a Gram Bretanha, em Flandes, em França, em toda Hefpanha, \& em Italia? para naó fallar de outrías partes, \& do que vay para fóra da Europa, particularmente às Indias Orièntal, \& Occidental: procurando-fe o do Brafil, por mais perfeito, \& melhor curado; em mayor quantidade da que felhe póde mandar, por nao faltarem os Commifarios aos Mercadores, que trataó de prover as partes mais pro: ximas.

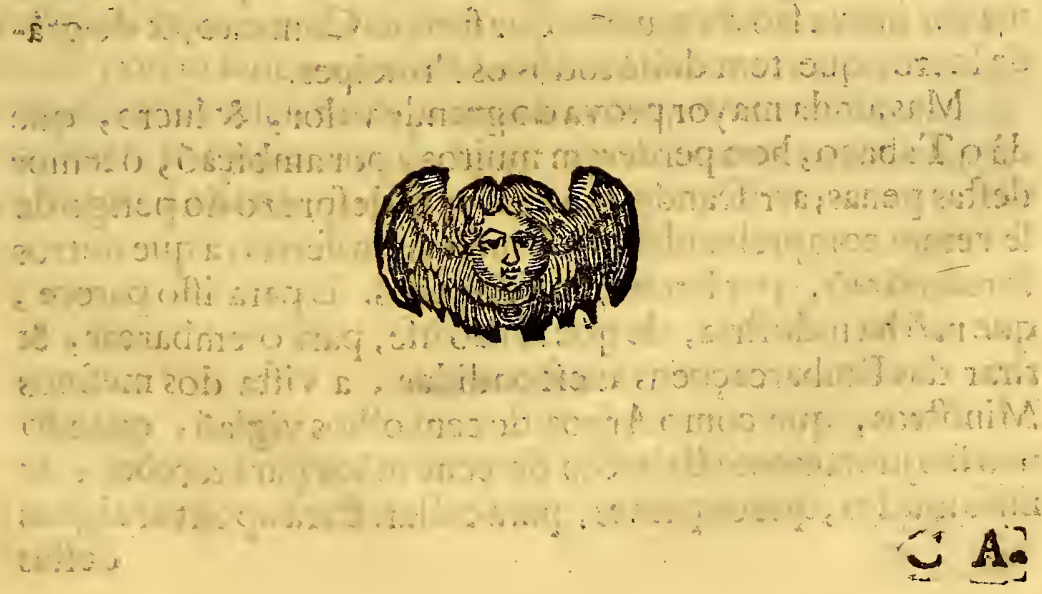




\section{6}

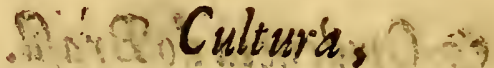

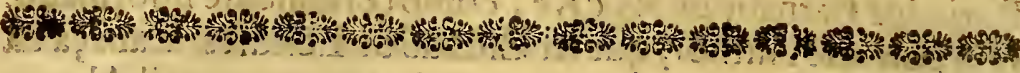

C A I T U L O XII.

Das penas dos que le ziă Tabaco naó despacha= do nas Alfandegas: Eo das indufrias, de que se usa para feleruar de cons trabando.

Q Ualquer defcaminhodo Tabaco, por qualquer deftas partes do Brafil', fóra do Regifito, \& Guias, debaixc do que tudo vay defpachado, têm por pena a perda do Tabaco s \& da Embarcaçaó, em que feachar, \& mais cinco annos de degredo para Angola ao Author defta culpa. Porém muito mayores faó as peras, que tem os transgreffo. res do bandoem Portugal. E em outros lieynos fá́ tantas, \& tam graves, que a cada paffơ fá caufa da ruina de muitas Familias. E quanto mais rigorofas faó eftas penas; tanto mayor prova faó do muito a que fubio o Contrato, \& do grãde lurcro, que tem delle todos os Principes.

Mas ainda mayor prova do grande valor, \&lucro, que dà o Tabaco, he o perderem muitos, porambiçaó, o temor deftas penas; arrifcando-fea ellas coni defprezo do perigo de fe verem comprehendidos nas mefinas miferias, a que outros. fe reduzîraó; por ferem tam confiados. E para iffo parece, que naó ha induftria, de que fe naó ufe, para o embarcar, \& tirar das Embarcaçoens às efcondidas, à vifta dos mefmos Miniftros, que como Argos de cem olhos vigiaó; quando naó faó juntamente Briarếos de cem máos para receber; \& mais mudos, que os peixes, para callar. Para apontar algúas 


\section{ÉOpuleñcia do Brafl.}

deftas induftrias, direy, por relaçaó dos cafos, em que fe apanhâraó naó poucos; "q huns mandâraó o Tabaco dentro das peças da artilharia; outros dentro das caixas, \& fechcs do Affucar; outros arremedando as caras tambem de Aftucar muito bem encouradas. Servîraö-fe outros dos barrîs de Farinha da Terra,dos de Breo \& dos de Melado,cobrindo com a fuperficie mentirofa o que hia dentro em folhas de Flandes. Outros valeraó-fe das caixas de roupa , fabricadas a dous fobrados, para dar lugar a efcondrijos : de frafqueiras que eftaó á vifta, pondo entre os frafcos de vinho outros tambem de Tabaco. Quanto foy, \& vay cada anno nas obras mortas \& \& nos forros das cameras \& das varandas das Naos? Quanto nas curvas, que para iffo nas partes mais efcuras fe forraó? $\mathrm{E}$ naj faltou quem lhe déffe lugar até dentro de húas Image ns ocas de Santos; aflim como huns Carpinteiros de Navioso efcondèraó em paosocos, mifturados entre os outros, de que coftumaó valer-fe. Deixoo que entra, \& fae em algib eiras grandes de couro dos que vaô, \& vem das Naos para os Portos, com repetidas idas, \& voltas, debaixo de Lobas, \& Tunicas: \& o que fe arrafta debaixo dos batêis, \& das pipas da agua da pelas ondas do mar. Nunca acabariamos, fe quizeffemos relatar as invençoens, que fuggerio a cautela ambi- ciofa : porém fempre arrifcada, \& muitas vezes defcuberta, com fucceffo infeliz. O que claramente prova a eftimaçaó,o appetite, \& a efperança do lucro, que ainda entre rifcos acópanha ao Tabaco.

\section{ogseosseos.}

I E R. 
-

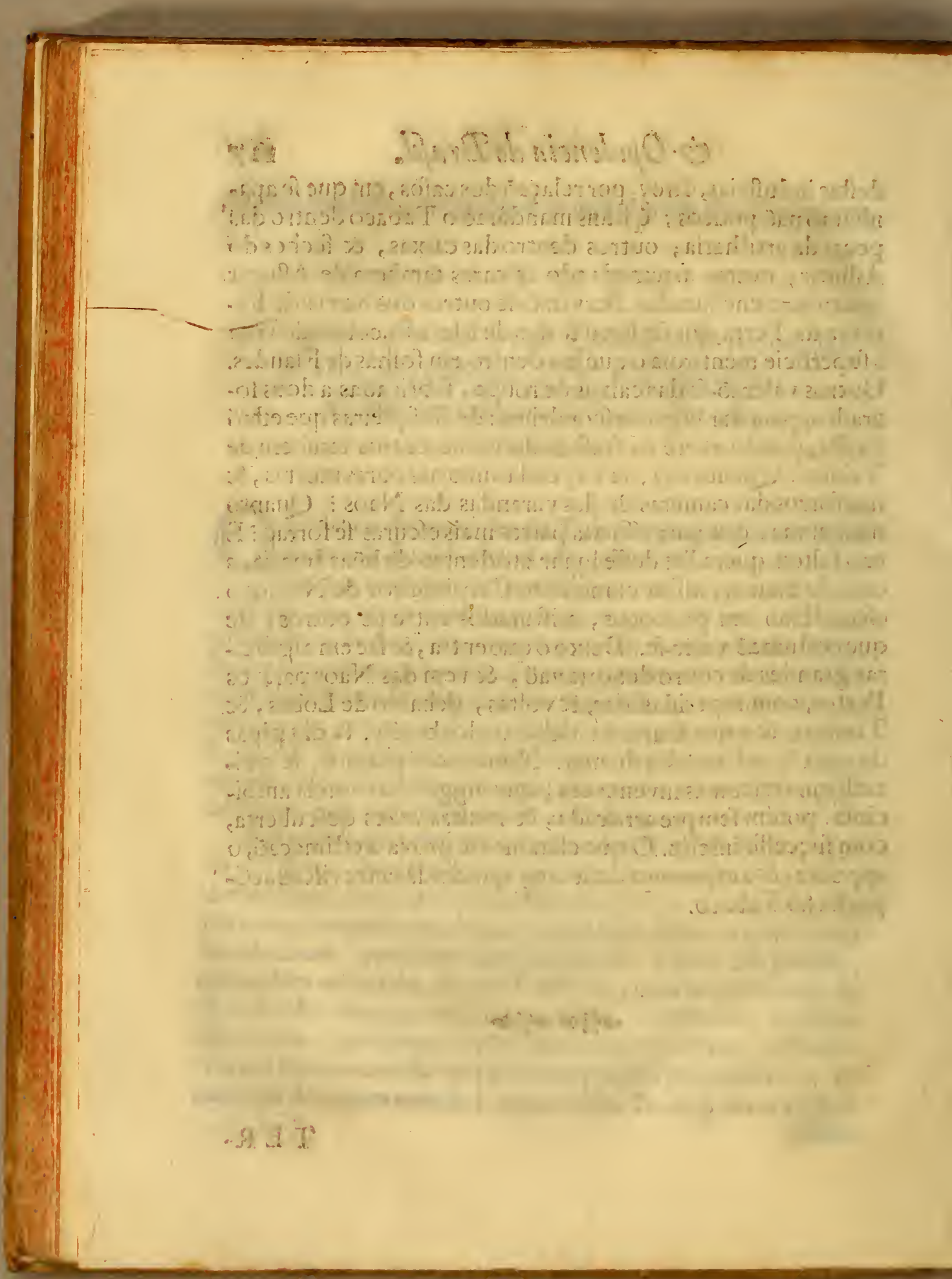




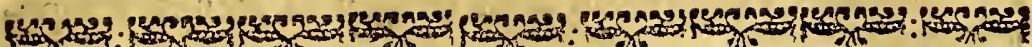

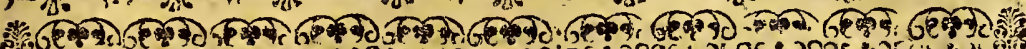
望 200.

\section{TERCEIRA PARTE.}

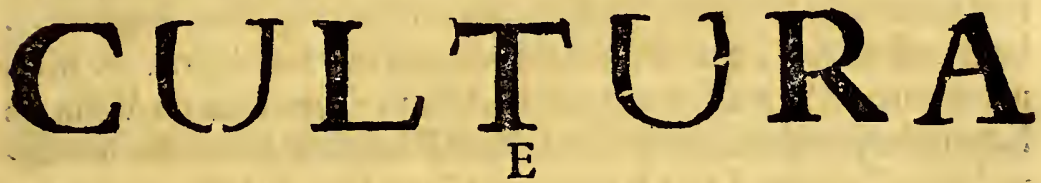

\section{OPVLENCIA DO BRASIL Pelas Minas do Ouro.}

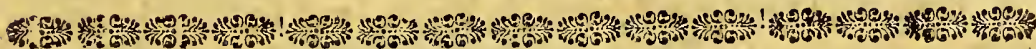

\section{A P I T V L O I.}

\section{Das eninas do Ouro, que (e de/cobris rấ no Bralil.}

Oy fempre fama conftante, que no Brafil havis Q B Minas de Ferro, Ouro, \& Prata.Mas tambem houve fempre baftante defcuido de as defcobrir, \& de aproveitar-fe dellas : ou porque contentando-fe os Moradores com os frutos, que dá a Terra abundantemente na fua fuperficie; \& com os peixes, que fe pefcaó nos Rios. grandes, \& apraziveis; naó tratâraó de divertir o curfo natural deftes, para thes examinarem o fundo, nem de abrir. áquella as entranhas, como perfuadio a ambiçaó infaciavel 2 outras mujtas Naçoens : ou porque o genio de bufcar.In. I

dios 
dios nos mattos os defviou defta diligenciä "menos efcrupu: lofa, \& mais util.

Na Villa de Saó Paulo ha muita pedra ufual, para fazer paredes, \& cercas; a qual com a cor, com o pezo, \& com as veas, que tem em fi, moftra manifeftamente, que naó defmerece o nome, que lhe deraó de Pedra ferro; \& q donde ella fe tira, o ha. O que tambem confirma a tradiçaó de que já fe tirou quantidade delle, \& fe achou fer muito bom para as obras ordinarias, que fe encommenda6 aos Ferreiros. E ultimamente na Serra Ibirafoyấba, diftante oito dias da Villa de Serocâba, \& doze da Villa de Saó Paulo, a jornadas moderadas, o Capitaớ Luiz Lopez de Carvalho, indo lá por mandado do Governador Artúr de Sá, com hú Fundidor Eftrangeiro, tirou ferro, \& trouxe barras, das quaes fe fizeraó obras excellentes.

Que haja tambem Minas de Prata, naô fe duvîda : porque na Serra das Colunas, quarenta legoas alem da Villa de Outû, que he húa das de Saó Paulo ao Lefte direito, ha certamente muita prata, \& fina. Na Serra de Seboraboçû́ tambem a ha: Da Serra de Guarumê defronte do Cearâ tirâraó os Hollandezes quantidade della no tempo, em que eftaraó de poffe de Pernambuco. E na Serra de Itabayâna, ha tradiçaó, que achou prata o Avó do Capitaó Belchior da Fonfeca Doria. E em buf ca de outra foy alem do Rio de Saó Francifcó Lopo de Albuquerque, que faleceo nefta fua malograda em. preza.

$\because$ Mas deixandoas Minas de Ferro, \& de Prata, como inferiores; paffemos ás do Ouro, tantasem numero, \& taó rendofas aos que dellas o tiraó. E primeiramente he certo, que de hum Outeiro alto, diftante tres legoas da Villa de Saớr Paulo, a quem chamáo Jaraguâ, fe tirou quantidade de ou. ro, que paffou de oitavas a livras. Em Parnaíba, tamben junto da mefma Villa no Serro Ibiturûna, fe achou Ouro, \& tirou-fe 


\section{Eo Opulencia do Brafl.}

thoulfe por oitavas. Muito mais, \& por muitos annos fe cont tinuou a tịar em Parnaguâ, \& Coritîba, primeiro por oita. vas, depois por livras, que chegânraó a alguma arroba, pofto que com muito trabalho para o ajuntar, fendo o rendimento no catar limitado; atè que fe largâraó, depois de ferem defcubertas pelos $P$ auliftas as Minas Geraes dos Cataguâs, \& as que chamaó do Caetê; \& as mais modernas no Rio das Velhas, \& em outras partes, que defcobrîraó outros Pauliftas: $\&$ de todas eftas iremos agora diftintamente fallando.

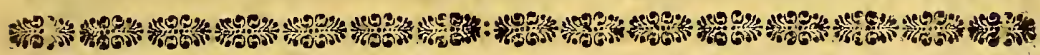

\section{A P I T U L O II.}

\section{Das Minas do Ouro, que chamato Geraes: $\sigma^{\circ}$ dos descobridores dellas.}

H A poucos annos, que fe começâraó a defcobrir as Minas Geraes dos Cataguâs, governando o Rio de Janeiro Artúr de Sá : \& o primeiro defcobridor dizem, que foy hum Mulato, que tinha eftado nas Minas de Parnaguâ, \& Coritîba. Efte indo ao Certaõ com huns Pauliftas a bufcar Indios, \& chegando ao Serro Tripuî, deceo abaixo com huma gamella, para tirar agua do Ribeiro, que hoje chamaó do Ouro preto: \& metendo a gamella na ribanceira para tomaragua, \&roçando-a pela margem do Rio; vio depois, que nella havia granitos da cor do aço, fem faber o que eraó: nem os companheiros, aos quaes moftrou os ditos granitos, fouberaō conhecer, \& eftimar o que fe tinha achado taô facil. mente; \& fócuidâraó, que ahi haveriạ algum metal, naó bem formado, \& por iffo naó conhecido. Chegando porèm: a Taubatê, naố deixâaraó de perguntar, que calta de metal I2. reria 


\section{Cultura,}

feria aquelle: E fem mais exame," vendèraó a Miguel de Souifa alguns deftes granitos, por meya pataca a oitava , fem fa: berem elles o que vendiaó, nem o comprador que coufa comprava; atè que fe refolvèraó a mandar alguns dos granitos ao Governador do Rio de Janeiro Artûr de Sá : \& fazendo-fe exame delles, fe achou, que era Ouro finiffimo.

Em diftancia de meya legoa do Ribeiro do Ouro preto; achou-fe outra Mina, que fe chama a do Ribeiro de Antonio Dias : \& dahi a outra meya legoa a do Ribeiro do Padre Joaó de Faria : \& junto defta, pouco mais de húa legoa, a do Ribeiro do Bueno, \& a de Bento Rodriguez. E dahitres dias de caminho moderado atè o jantar, a do Riberraó de Noffa Senhora do Carmo, defcuberta por Joaó Lopez de Lima; alèm de outra, que chamaó a do Ribeiro Ibupiranga. E todas eftas tomâraó o nome dos feus defcobridores, que todos.foraó Paulifitas.

Tambem ha h̀ía paragem no caminho para as ditas $\mathrm{Mi}$ nas Geraes, onze, ou doze dias diftante das primeiras,andan do bem até as tres horas da tarde : a qual paragem chamaó a do Rio das Mortes, por morrerem nella huns homens, que o paffáraó nadando; \& outros, que fe matàraó às pelouradas, brigando entre fi fobre a repartiçáo dos Indios Gentios, que traziaó do Certaó. E nefte Rio, \& nos Ribeiros, que dellè procedem, \& en outros, que vem a dar nelle, fe acha Ouro: \& ferve efta paragem, como de eftalagem dos que vaóás Minas Geraes; \& ahi fe provèm đo neceffario, por terem hoje cs que ahi affiftem, Roças, \& creaçaó de vender.

Naó fallo da Mina da Serra de Itatiaya, (a faber do Ourobranco, que he Ouroainda naó bem formado ) diftante do Ribeiro do Ourolpreto oito dias de caminho moderado atèo jantar: porque defta não fazem cafo os Pauliftas, por terem as outras de Ouro formado, \& de muito melhor rendimento. E eftas Geraes, dizem, que ficão naaltura da Capitaniado Efpirito Santog

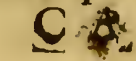




\section{G. Opulencia do Brafi.}

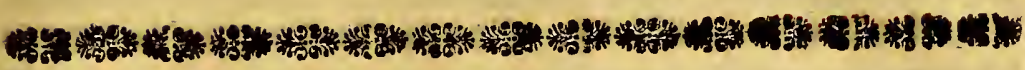

$$
\text { C } \quad \begin{array}{lllllllllll} 
& \mathbf{P} & \mathbf{I} & \mathbf{T} & \mathbf{U} & \mathbf{L} & \mathrm{O} & \text { III. }
\end{array}
$$

De outras Minas de Ouro no Rio das Velbas, Er no Caetê.

A Lem das Minas Geraes dos Cataguâs, defcobríraó-fe outras por outros Paulittas no Rio, que chamaó das Velhas: \& ficaó, como dizem, na altura de Porto-feguro, \& de Santa Cruz. Eeftas faó, a do Ribeirodo Campo, defcuberta pelo.Sargento Mór Domingos Rodriguez da Fonfeca: a do Ribeiro da Róça dos Penteados : a de Noffa Senhora do Cabo, da qual foy defcobridor o mefno Sargento Mór Domingos Rodriguez : a de Noffa Senhora de Monferrate : a do Ribeirodo Ajudante : \& a principal do Rio das Velhas he a doSerrode Seboraboçû́, defcuberta pelo Tenente Manoel Borba Gato Paulifta, que foy o primeiro, que fe a poderou della, \& do feu Territorio.

Ha mais outras Minas novas, que chamaó do Caetê, eñtre as Minas Geraes, \& as do Rio das Velhas, cujos defcobridores foraó varios: \& entreellas ha a do Ribeiro, que defcobrio o Capitaó Luis do Couto, que da Bahia foy para effa paragem, com tres Irmăos, grandes Mineiros; alem de oultras, que fecretamente fe achaó, \& fe naó publicaó, para fe aproveitarem os defcobridores dellas totalmente, \& naó as fujeitarem á repartiçaó $: \&$ as que ultimamente defcobrio o Capitaó Garcia Rodriguez Paez, quando foy abrir o caminho novo detraz da Cordelheira da Serra dos Urgaós, no diftricto do Rió de Janeiro, por ende corta o Rió Paraîba do Sul: 


\section{I $34^{4}$}

\section{Ansidura:}

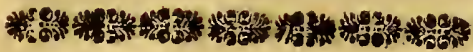

\section{A PII U L O IV?}

Do rendimento dos Ribeiros : Eo de diverfas qualidades de Owro, que delles se tira.

D As Minas Geraes dos Cataguás as melhớes; \& de ñayor rendimento foraó até agora a do Ribeiro do Ouro preto ,... a do Ribeiraó de Neffa Senhora do Carmo , \& a do do Ribeiro de Bento Rodriguez;do qual em pouco mais de cińcóbraçás de terra fé tirárao cinco arrobas de Ouró. Tambem o Rio das Velhas he maito abundante de Ouro affim pelas margens, como pelas Ilhas, que tem, \& pela Madreou Veyơ da agua: \& delle fe term ritado, \& fe tira ainda em quantidadeabundante:

Chamaó os Pauliftas Ribeiro de bom rendimento; o que dá em cada bareada duas oitavas de Ouro. Porém affinicomo ha bateadas de meya oitava, \& de meya pataca; aflim ha taimbem bateadas de tres, quatro, cinco; oito, dez, quinze, vinte, \& trinta oitavas , \& mais: \& ifto naó poucas vezes fuccedeo na do Ribeiráó, na do Ouro preto, na de Bento Rodriguez, \& na do Rio das Velhas:

Os grãos de mayor pezo, que fe tirăraó, foraō hum de noventa \& cinco oitavas: outro de tres livras; que repartîraó entrefi tres Peffoas com hum machado: outro, que paffiou decento \& cincoenta oitavas, em forma de hüa lingua de Boy, que fe mandou ao Governador da Nova Colonia : \& outro mayor de feis livras.

Quanto ás qualidades diverfass do Ouro: fabe-fe $j$ que o Ouro, a quem chamaó preto, por ter na fuperficie hüa cor

feme: 


\section{EO Opulencia do Brafl.}

femelhante á do aço, antes de ir ao fogo, provando-fe com o dente logo apparece amarello, vivo, gemado, \& he o mais fino; porque chega quafia vinte \& tres quilates : \& quando feillhe poem o cunho na fundiçao, faz gretas na barreta, $\mathrm{CO}^{-}$ mo fe arrebétaffe de todas ás partes: : \& por dentro dútaes ret flexos, que pareceim rayos do Sol. O do Ribeiraó he mass miudo; \& mais polme; \& compete na bondade com o Ouro preto; porque chega a vinte 8 dous quilates. O Ourodo Ribeiro de Bento Rodriguez, pofto que feja mais groflo, \& palpavel, \& bem amarello; comtudo naó tem a perfeiçaó do Ouro preto, \& do Ouro do Ribeiraô"; mas quando muito; chega a vinte quilates. O Ouro do Ribeiro do Campo, \&o do Ribeiro de Noffa Senhora de Monferrate he groffo, \& muito amaello, \& tem vinte \& hum quilates \& meyo. $O$ Ouro do Rio das Velhas he finifimo, \& chega a vinte \& dous quilates. $\Theta$ Ouro finalmente do Ribeiro de Itatiaya he de cor branca, como a prata, por naó eftar ainda bem formado, como diffemos acima: \& defte fe faz poucocaro; pofto que alguns digaó, " que indo ao fogo âs vezes por mais formado; foy moft rando a cor amarella.

Houve anno, em que de todas eftas.Minas, ou Ribeiros fe tirâraó mais de cem arrobas de Ouro ; fóra o que fe tirava, \& tira efcondidamente de outros Ribeiros, que os défcobridores naó manifeftâraó; para os náo fujeitarem logoá reparti çaó. E fe os quintos de ElR ey chegâraó a dezafete, \& a vinte rrobas, fonegando-fe tanto Ouro naó quintado; bem fe leixa ver, que o Ouro, que cada anno fe tira, fem encarecilento algum paffa de cem arrobas $\therefore$ \& que neftes dez annós affados fe tem tirado mais de mil arrobas. E fenos primeiros nnós naó chegâraó a cem arrobas ; nos outros certamente affáraó. E continuădo ao prefente o rendimento com igủal, ll com mayor abundancia por razaó do mayor numero dos te e empregaó em catar; fó os Quintos; devidos a Sua Ma -1 
geftade, fe foraó notavelmente diminuindo: ou pur feüurvertir para outras partes o Ouro em pó ; ou por naoó ir á Cafa dos Quintos; ou por ufarem alguns de cunhos falfos, com engano mais deteftavel. Mas ainda affim náo deixou Sua Mageftade de ter grande lucro na Cafa da Moeda do Rio de Janeiro: porque comprando o Ouroa doze toftoens a oitava, \& batendo-fe em dous annos tres milhoens de moeda nacional, $\&$ provincial de ouro; foy lucrando feiscentos mil cruzados de avanço.

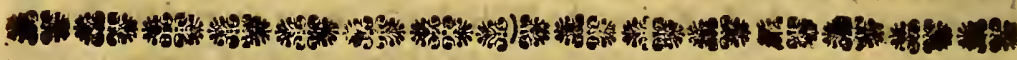 \\ C A P T U L O V: \\ Das PefJoas, que andao nas Minas, Eo tira Ouro dos Ribeiros.}

A Sede infaciavel do Ouro eftimulou a tantos a deixa: 1 rem fuas Terras, \& a meterem-fe por caminhos tam âf eros, como faó os das Minas; que difficultofamente fe poderá dar conta do numero das Peffoas, que actualmente là eftaó. Comtudo as que affiftîraớ nellas neftes ultimos annos. porlargo tempo, \& as corrèraō todas, dizem, que mais de trinta mil Almas fe occupão, hưas em catar, \& $\&$ outras em. mandar catar nos Ribeiros do. Ouro; \& outras em negociar, vendendo, \& comprando o que fe hamifter naó fó para a vida, mas para o regalo, : mais que nos Portos do Mar.

Cada anno vem nas Frotas quantidade de Portuguezes; $\&$ de Eftrangeiros, para paffarem às. Minas. Das Cidades; Villas, Reconcavos, \& Certoens do Brafil vaó Brancos, Pardos, \& Pretos; \& muitos Indios, de que os Pauliftas fe fervem. A miftura he de toda a condiçaó de Peffoas : Homens, 


\section{Co Opulencia do Brafll.}

mens, \& Mulheres: Moços, \& Velhos: Pobres, \& Ricos: Nobres, \& Plebeos: Seculares, \& Clerigos: \& Religiofos de diverfos. Inftitutos, muitos dos quaes naó tem no Brafil Convento, nem Cafa.

Sobre efta Gente quanto ao temporal naó houve atè o prefente coacçaó, ou governo algum bem ordenado : \& apenas fe guardão algumas Leys, que pertencem às Datas, \& Repartiçoens dós Ribeiros. No mais não ha Miniftros, nem Juftiças, que tratem, ou pofáó tratar do caftigo dos crimes, que naó faó poucos, principalmente dos homicidios, \& furtos. Quanto ao efpiritual, havendo até agora duvidas entre os Prelados acerca da Jurifdiçaố, os mandados de húa, \& outra parte, ou como Curas', ou como Vífitadores, fe acháraó baftantemente embaraçados : \& naб pouco embaraçâraó a outros, que naó acabaó defaber a que Paftor pertencem aquelles novos Rebanhos. E quando fe averigue o direito do provimento dos Parocos; pouco haó de fer temidos, \& refpeitados naquellas. Fréguezias móveis de hum lugar para outro, como os Filhos de Ifrael no Deferto.

Teve El-Rey nas Minas porSuperintendente dellas aơ Defembargador Jofeph Vaz Pinto, o qual depois de dous, ou tres annos tornou a recolher-fe para o Rio de Janeiro com baftante cabedal: \& delle fupponho ficaria plenamente informado do que por là vay ; \& que apontaria as defordens; \& o remedio dellas, fe forfe poflivel a execuçaó..

Affifte tambem nas Minas hum Procurador da Coroa, \& hum Guarda Mòr com feu eftipendio. Houve atè agora $\mathrm{Ca}$ fa de quintar en Taubatê, na Villa de Saó Paulo, em $\mathrm{Paz}$ ratij, \& no Rio de Janeiro: \& em cada húa deftas Cafas ha hum Provedor, hum Efcrivao, \& hum Fundidor; que fundido o Ouro em barretas, the poem o.Cunho Real, final do Quinto que fe pagoir a El-Rey deffe Ouro.

Havendo Cafas da Moeda, \& dos Quintos na Bahia, \& .

no. 


\section{8 \\ Cultura;}

no Rio de Janeiro ( por ferem eftes os dous Pólcs, aonde vay parar todo o Ouro) teria Sua Magentade muito mayor lucro, do que atè agora teve: \& muito mais, fe nas Cafas da Mceda; bem fornecidas dos aparelhos neceflarios, houveffe fempre dinheiro prompto para comprar o Ouro; que os Mineiros trazem, \& folgaó de o vender fem detença.

Agora foubemos que Suj Mageftade manda Goverria: dor, Miniftros de Juftiça, \& levantar hum Terço de Soldados nas Minas, para đ̆ tudo tome melhor fórma, \& governo.

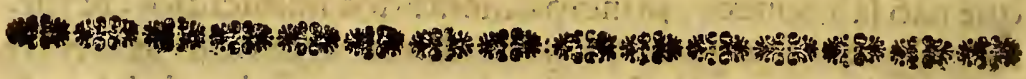

\section{A P I T U L O VI.}

\section{Das Datas, on Repartigoens das Minas.}

7 Ara evitar a confufaó, o tumulto, $\&$ as mortes, que ha1 veria no defcobrimento dos Ribeiros do Ouro, fe affentou o que pertence ás Repartiçoens defta forte. Tem o Defcobridor a primeira Data, como Defcobridor, \& outra como Mineiro:fegue-fe a que cabe a El-Rey, \& atraz defta a do Guarda Mór : as outras fe diftribuem por fortes. As que chamaó Datas inteiras, faó de trinta braças em quadra : \& taes faó a d' El-Rey, \& as do Defcobridor, \& Guarda Mór. As outras, que fe daó por fortes, tem a extençaó proporcionada ao numero dos Efcravos, que trazem para catar; dando duas braças em quadra por cada Efcravo, ou Indio, de que fe fervem nas catas: \& aflim a quem tem quinze $E$ fcravos fe dâ hŭa Data inteira dé trinta braças em quadra. Para fér admittido á Repartiçaó por fortes, he neceffario fazer petiçaó ao Superintendente das ditas Repartiçoens, ao qual fe dá pelo defpacho da petiçaó húa oitava de Ouro, \& outra ao feu Efcrivaó: \& ás:vezes acontece offerecéré-le quinhientas petiçoens, \& le-

varen 


\section{Eo Opulencia do 'Braju.}

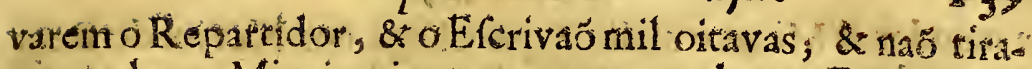
rem todos os Mineiros juntos outro tanto de taes Datas, por falharem no feu rendimento : \& por iffo procuraó outras $\mathrm{D}$ a. tas, havendo defco brimento de novos Ribeiros. $A$ Data $\mathrm{d}^{5}$ Ei-Rey logo fe vende a quể mais offerece: \& póde tamben qualquer vender, ou trocar a fua Data: \& nifto fe vîraö, \& vem a cada paflo varios, \& differentes fucceffos, tirando hús Mineiros de poucas braças muito Ouro; \& outros de muitas potico: $8 x$ já houve quem por potuco maisde mil oitavas ven. deo Data, da qual o comprador tirou fete arrobas de Otro. Pelo que fe tem por jogo de bem, ou mal afortunado, o tirar, cu naó tirar Ouro das Datas.

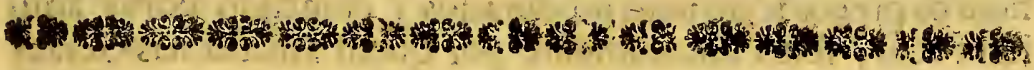

\section{A P I T U L O VII.}

Do abundancia de Nantimentos, Go de todo o usual, que boje ba nas Minas: Eo do pouca cajo que le faz dos pregos extraors dinariamente alcos.

Endo a Terra que da Ouro efterilinima de tudo o qué $\$$ fe ha mifter para a vida humana, \& naó menos efferi 2 mayor parte dos caminhos das Minas sa ná fe póde crea - que padecéraó ao principio os Mineiros por falta de mantimentos, achando-fe mó poucos mortos com huma efpis. ga de milho na maó , fem terem outro fuftento. Porèm tanto que fe vio a abundancia do Ouro, que fe tirava, $\&$ a largueza, com que fe pagava tido o que lá hia, logo fe fizeraô eftalagens, \& $x$. logo começâraó os Mercadores 


\section{$\$ 40$}

Culcura,

a mandar ás Minas o melhor que chega nos Navios do Reyno, \& de outras partes, affim de mantimentos, como de regalo, \& de pompofo para fe veftirem ; alem de mil bugiarias de França, que lá tambem foraó dar. E a efte refpeito, de todas as partes do Brafil fe começou a enviar tudo o que dá a Terra, com lucro naó fómente grande, mas excefívo. E naó havendo nas Minas outra moeda mais que Ouro em pó; o menos que fe pedia, \& dava por qualquer coufa, eraó oitavas. Daquife feguio, mandarem-fe às Minas Geraes as Boyadas de Parnaguâ, \& às do Rio das Velhas as Boyadas dos Campos da Bahia ; \& tudo omais , que os Moradores imaginavaô poderia appetecer-fe, de qualquer genero de coufas naturaes, \& induftriaes, adventicias, \& proprias. E ainda que hoje os preços fejaó mais moderados; comtudo porey aqui hum $\mathrm{Rol}$, feito finceramente por quem affiftio nas Geraes tres annos, dos preços das coufas, que por conmmum affento là fe vendiaố no anno 1 703 repartindo-o em tres ordés : a faber, os preços que pertencem às coufas comettiveis; os do veftuario, \& armass ; \& os dos Efcravos, \& Cavalgaduras" faó os feguintes.

\section{Pregos das coufas comeftiveis.}

\section{Or hŭa Rez oitenta oitavas.}

Por hum Boy cem oitavas.

Por hũa mão de feffenta efpigas de Milho trinta oitavas.

Por hum alqueire de Farinha de Mandiôca quarenta oitavas.

Por feis bolos de farinha de Milho tres oitavas.

Por hum Payo tres oitavas.

Por hum Prezunto de oito livras dezafeis oitavas.

Por hum Paftel pequeno hüa oitava.

Por húa livra de Manteiga de. Vaca duas oitavas. 


\section{¿o Opulencia do Brafl.}

Por húa Gallinha tres ou quatro oitavàs.

Por feis livras de carne de Vaca húa oitava.

Por hum Queijo da Terra tres on quatró oitavas, conforme o pezo.

Por hum Queijo Flamengo dezafeis oitavas.

Por hum Queijo de Alemtejo tres \& quatro oitavas.

Por húa boceta de Marmelada tres oitavas.

Por hum frafco de Confeitos de quatro livras, dezafeis oi: tavas.

Por hũa Cara de Affucar de húa arroba 32 oitavas.

Por hứa livra de Cidraó tres oitavas.

Por hum barrilote de Agua ardente, carga de hum Efcravo cem oitavas.

Por hum barrilote de Vinho, carga de hum Efcravo, duzen: tas oitavas.

Por hum barrilote de Azeite diuas livras:

Por quatro oitavas de Tabaco em pó com cheiro húa oitava Por feis oitavas de Tabaco em pó fem cheiro húa oitava.

Por húa vara de Tabaco em corda eres oitavias.

Preços das coufas, que pertencem ao veftuario, \& armas.

- D Or húa Caçaca de Baeta ordinaria doze oitavas. Por húa Caçaca de Panno fino vinte oitavas.

Por húa Vefte de feda dezafeis oitavas:

Por huns Calçoens de Panno fino nove oitavas.

Por huns Calçoens de feda doze oitavas.

Por húa Camiza de linho quatro oitavas.

Por húas Ciroulas de linho tres oitavas.

Por hum par de Meyas de feda oito oitavas.

Porthum par de C,apatos de Cordovaó cinco oitavas:

Por hum Chapeo fino de Caitor doze oitavas.

Por hum Chapeo ordinario feis oitavas: 


\section{Cultura,}

Por húa Carapuça de feda quatro ou cinco oitawas.

Por húa Carapuça de panno forrada de feda cinco oitavas.

Por húa boceta de Tartaruga para Tabaco feis oitavas.

Por hũa boceta de prata de relevo para Tabaco, fe tem oito oitavas de prata, daó dez, ou doze de ouro, conforme ofeitiodella.

Por hũa Efpingarda fem prata dezafeis oitavas.

Por hía Efpingarda bem feita, \& prateada, cento \& vinte oitavas.

Por hũa Piftola ordinaria dez oitavas.

Por húa Piftola prateada quarenta oitavas.

Porhúa faca de ponta com cabo curiofo feis oitavas:

Por hum Canivete duas oitavas.

Por hũa Tizourra duas oitavas.

E toda a bugiaria, que vem de França, \& de outras partes, vende-feconforme o defejo, que moftraó ter dellas os compradores.

\section{Preços dos Efcravos, \& das Cavalgaduras,}

D. Or hum Negro bem feito, valente, \& ladino trezentas oitavas.

For hum Molecaó duzentas \& cincoenta oitavas.

Por hum Moleque cento \& vinte oitavas.

Por hum Crioulo bom Official quinhentas oitavas.

Por hum Mulato de partes; ou Official quinhentas oitavas:

Por hum bom Trombeteiro quinhentas oitavas.

Por hũa Mulata de partes, feiscentas ; \& mais oitavas:

Por húa Negra ladina Cozinheira trezentas \& cinccenta oi tavas.

Por hum Cavallo fendeiro cem oitavas.

Por hum Cavallo andador duas liv ras de Ouro.

Eeftes preços tam altos, \& tam correntes nas Minas: 


\section{E. Opulencia do Brafll.}

foraó caufa de fubirem tanto os preços de todas as coufas, co. mo fe experimenta nos Portos das Cidades, \& Villas do Brafil ; \& de ficarem desfornecidos muitos Engenhos de Affucar das Peças neceffarias; \& de padecerem os Moradores grande careitia de mantimentos, por fe levar sm quafi todos, aonde vendidos haó de dar mayor lucro.

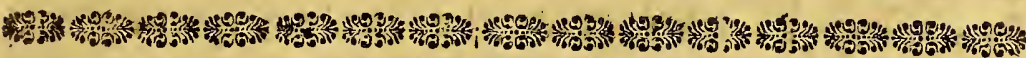

\section{A P I T U L O VIII.}

Dediverfos pregos do Ouro vendido no Brafll: $\xi^{\circ}$. do que importa o que cada anno ordinarias: mente se tira das eVinas.

W Arios forá os preços do Ouro no difcurfo deffes: an: nos: naớfó pơ razaoó da perfeiçaó de hum, mayor q́ a dooutro, por fer de mais fubidos quilates; mas tambem a refpeito dos Lugares, aonde fe vendia : porque nais baratơ fe vende nasiMinas, do que rna Villa de Saó:PauIo, \& de Santos: \& muito mais val nas Cidades do Rio de Janeiro, \& da Bahia, do que nas Villas referidas. Tambem nuito mais val quintado, do que em pó: porque oque fe vendeem pó, fae do fogo com baftantes quebras: alem do que vay de differen. ça por razaó do que fe pagou, ournaó fepagourdequintos.

Hũa arroba de Ouroem pó pelo preço da Bahia, a quatorze toftoens a oitava,importa quatorze miltrezentos \& trintz \& feis cruzados. Quintado, pelo preço da Bahia a dezafeis toftoens a oitava, importadezafeis mil trezentos \& ${ }^{2}$ oitenta \& quatro cruzados.

Húa arroba de Ouro ent pó pelopreço doRio de Janeiroja treze toftoens a oitava, importa treze mil trezentos \& doze 
doze cruzados. Quintado, a quinze toftcens a oitava, impor ta quinze mil trezentos \& feffenta cruzados.

Donde fe fegue, $\bar{q}$ tirando-fe cada anno mais de cem arrobas de Ouro, a quinze toftoens a oitava, preço corrente na Bahia, \& noRiode Janeiro, fendo quintado, vem a importar cada anno hum milhaó quinhêtos \& trinta \& feis mil cruzados. Das quaes cem arrobas, fe fe quintarem, como he juflo, rabem a Sua Mageftade vinte arrobas, "que importaó trezentos \& fete mil \& duzentos cruzados, mas he certo que cada anno fe tiraó mais de trezentas arrobas.

E com ifto naó parecerá incrivel o que por fama conftante fe.conta haverem ajuntado em diverfos tem pos affim huns Defcobridores dos Ribeiros nomeados, como huns mais bem afortunados ras Datas: \& tambem os que metendo $\mathrm{Ga}$ do , \& Negros para os venderem por mayor preço, \&r outros generos mais procurados, ou plantando, ou comprando Roças deMilho nas Minas, fe fóraó aproveitando do que ou. tros tirâraó. Naó fallando pois do grande cabedal, que tirou o Governador Artúr de Sá , que duas vezes foy a ellas do Rio de Janeiro: nem dos que ajuntârăó húa , duas, \& tres arrobas, que naó foraó poucos. Ten-fe porcerto, que Baltha. farde Gọôy, de Roças, \& Catas ajuntou vinte arrobas de Otiro. De varios Ribeiros, \& da negociaçaó com Roças, Ne- । gros, \&z Mantimentos fez Francifco de Amaral mais de cincoenta arrobas. Pouco menos Manoel Nunez Viana, \& Manoel Borba Gato : \& com baftante cabedal fe recolheo para Saó Paulo Jofeph Goes de Almeyda ; \& para o Caminho novo Garcia Rodriguez Paez. Joaó Lopez de Lima tirou da feu Ribeiraó cinco arrobas : os Penteados de fuas lavras, \& induftrias, fete arrobas: Domingos da Silva Moreira de negocio, \& lavra, cinco arrobas: Rafael Carvalho cinco arro. bas : Joaó de Goes cinco arrobas: Amador Bueno da Veiga, do Rio do Ouro preto , do Ribeiraó, \& de outras partes, ol 


\section{GOpulenciadoBrafal.}

145

to arrobas. E finalmente deixando outros muito bem aproveitados: Thomás Ferreira abarcando muitass Boyadas de Gado, que hia dos Campos da Bahia para as Minas, \& comprando muitas Roças, \& occupando muitos Efcrayos nas Catas de varios Ribeiros, chegou a ter mais de quarenta arrobas de Ouro, parte em fer, \& parte para fe cobrar. Mas tratando de cobrar o Ouro, que fe lhe devia, houve entretanto quem lhe deo por defgoftos húas poucas balas de chumbo; que he o que fuccede naó poucicas vezes nas Minàs.

Tambem com vender coifas comeftiveis, Agua ardente, \& Garapas, muitos em breve tempo accumulâraó quantidade confideravel de ourọ. Porque comò os Negros, \& os Indios efcondem baftantes oitavas, quando cataoo nos Ribeiros; \& nos dias fantos, \&z nas ultimas horas do dia tiraó Ouro $\mathrm{pa}^{-}$ ra fi ; a mayor parte defte Ouro fe gafta em comer, \& beber: $\&$ infenfivelmente dâ aos vendedores grande lucro, como coftuma dar a chuva miuda aos campos, a qual continuando a regallos fem eftrondo, os faz muito férteis. E por iffo até ós homens de mayor cabedal naố deixâraó de fe aproveitar por efte caminho deffa Mina á flor da Terra, tendo Negras com zinheiras, Mulatas doceiras, \& Crioulos Taverneiros, occupados nefta rendofiflima Lavira; \& mandando vir dos Portos do Mar tudo o que a gula coftuma appetecer, \& bufcar.

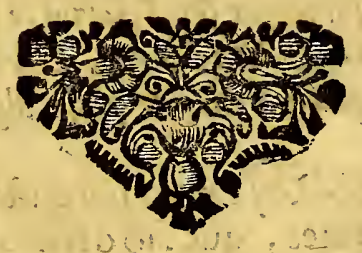




\section{B C Cultura:}

(cen

-

\section{A P I T U L O IX.}

Da obrigaçaó de pagar a El-Rey nolfo. Senbor - quinta parte do Ouro, que se tira das Minas. do Brajal

E dous modos fe póde tratar efte ponto: a faber, oú 1 pelo q́ pertence ao foro ex terno pelas Leys, \& Ordenaçoens do Reyno : on pelo que pertence ao foro interno, attentando á obrigaçaó em confeiencia.

Quanto á primeira parte, confta pela Ordenaçaó de Por:tugal liv.2.tit. 26. 5: 16. que entre os Direitos Reaes Je cont ăo os Veeyros, é. Minas de ouro, \& prata, é qualquer utrometal: Eno titulo 28: do mef́mo Livro 2: expreffamente fe declara: que nas Datas, or Doaçoens feitas, -nunca fe entendexáó comprehendidos os Veeyros, \& Minas. Porquanto ( diz a Ordenaçaó) em muitas doaçoës feitas per Nós, ¿u per os Reys noffos Anteceffores, [a $\vec{o}$ poftas algumas claufulles muito ger aes; \& exuberantes: declaramos, que per taes doaģö́s, \& claufulas nellas conteudas, nunca fe entende ferem dados os Veeyros, ơ Minas, de qualquer forte que fejắ; falva fe expreffamente forem nameadas, \& dad as nadita doaça $\overrightarrow{0}$. E para a prefcrip çao das. ditas coufas, nă se poderáallegar pofje alguma, pofto que feja.
immemorial.

Podendo pois El-Rey tirarà fua cufta das Minas, que referva para fi, os metaes, que faó of fruto dellas: attendendo 2os gaftos que para iffo faó neceffarios; \& querendo animar. as feus Vaffallos ao defcobrimento das ditas Minas , \& a participas: 


\section{Opulenciado Brâl.}

ticiparem dolucro dellas : affentou, como fe diz no tit. 34 : do dito Liviro 2. das Ordenaçoens, que de todos os metaes, que Je tirarem, depois de fundido, \& apurado, paguemo quinto, em falvode todosos cuftos.

E para fegurar, que fe lhe pagaffe o dito quinto, mandou, que os ditos metaes fe marcaffem, \& que fe naó pudeffem vender antes de ferem quintados, nem fóra do Reyno, fob pena de perder a fazenda, \& de degredo de dez annos para o Brafil; conó confta do dito tit. 34 4.5.5. E o que vender os ditos metaes antes de ferem marcad os, ou em madre antes de fun didos, perderá a fazenda, \& ferà degradado dez annos para o Brafil. Até aquia Ordenaçaó.

- Eos Doutores, que fallâraó nefta materia, aflim Portuguezes, como de ouțras Naçoens, affirmaó concordemen. te, ferem de tal forte as Minas do Direito Real, por razaó dos gaftos, que El-Rey faz em prol da Republica ; que por efta caúfa naó os póde alienar. Veja-fe entre outros Portuguezes Pedro Barbofa ad L. Divortio $\mathfrak{S}$. Si vir ff. foluto matrimonio à n. I 7. ufque ad $2 \mathrm{r}$. Cabedo parte 2. decif 55 . de venis metallor. Pegas ad Ord.Regni Port.lib.2.tit. 28:n.24 com os Authores de outros Reynos, que allegaó : particularmente a Lucas da Penna L. Quicumque defertum col. 2. poft princi- piúm Cod. de omni agro deferto, \& Rebuffo tom.2.ad leges, Gallix tit. ut beneficia ante vacationem art. 1 . gloffa ult: poft medium pag.346. Ealem deltes veja-fe Solorzano de Indiar. Gubern.tom.2:lib. I.cap: I 3. n. 55 . \& lib.5.cap.I.n. I9.com outros muitós, que traz: o qual diz, ferefte o coltume de todas ás Gentes. Qua de can a (diz dicto n. 55.) metalloramfodien dorum jus ipfi Romani, \& poftmodium alie Gentes inter Regalia computárunt, \& proprie ad locorum fupremos Principes per: tinere fanxerunt.

E Eorque nefta materia bem he ouvir tambem aos Theologos, feja o primeiro o P. Molina de Juftit. \& Jure difp. 54 $\mathrm{K}_{2}$

tam 


\section{Culturd,}

tam verfado no Direito, comona Theologia, \& mnito particularméte no Direito de Portugal.Regulariter(diz elle) de jure civili,vel cómuni, vel particulariù Regnorum, ubicumá ven $x$ metallorú fuerint repertæ , merito folent effe deputatx Principi ; aut Réipublicx ad fumptis publicos , oneraque Reipublicx fuftinenda: unde $5: 16$. tit.26.lib. 2. Ord.Lufita. nix Regni fichäbet: Item Direito Real be os Veeyros, \& Minas de ouro, \& prata, ou qualquier outro metal. Ut tamen lucri fpehomines allicianturadeas in bonum publicum quxrendas, \& aperiendas, ftatui folent varix leges pro temporum \& locorum varietate, quibus vel pars aliqua eorum, qux inde fuerint extracta, vel primia alijs inventoribus conftituuntur. E in terminis pela Ordenaçaó de Portugal diz : Cốceffum, \& ftatutum eft, ut deductis expenfis, quinta metallorum pars, qux inde extraeta fuerit, Regi perfolvatur.

O Padre Vafquez in Opufculis Moralibus deReftitutio: ne cap. 5.5.4. dub. 2. fallando do Reyno de Caftella diz : In noftro Regno applicata funt patrimonio Regio quxcumque: Mineralia, ubi metalla fiunt argenti, auri; \& argenti vivi per 1.6.Recop.tit. I3.1.4. Sed quo jure (diz elle) Rex potuerit fibiapplicare Mineralia omnia, in fundis etiam privatis procreata, nullus Authorum dixit, quos citavi. Mihi videtur ad bxc dicendum, quòd quanıvis Mineralia jure naturali fine ' dominiipfius agri, potuit hoc jus. Mineralium ab antiquo eflè inductum, quiod fint Regij. Patrimonì : eâ enim conditione potuerunt hujus Regni terrx, \& prædia diftribui, ut ta. men Mineralia Regibus refervata manerent, fivo Patrimonio: annimerata.

E a mefma razaó dá Molina de Júft \& Jure difp.5.6.5.ult. por eftas palavras. Licèt enim ftando in folo Gentium jure, ea inventa, qux domino carent, fint primò occupantis; nihi. lominus, quemádmodium jus civile ftatuere potuit, ut qui cafu thefaurum in agro alieno inveniret, in interiori, o ex- 


\section{copulencia do Bráfl.}

teriori foro teneretur tribuere illius dimidium domino agri y qui verò illum de induftria inveniret, teneretur tribuere cidem totum : curetiam non poterit fimili modoftatuere, ut ad fuftinenda Reipublicie onera, thefauri, qui deinceps inrenientur, pertineant integriad Regem, aut ut in illis certam aliquam habeat partem ? Neque enim id eft ftatuere aliquid contra jus Gentium; fed rationabili ex caufa impedire, ne dominium thefauri inventifit alicujus, cujus effet, ftando ir folo naturaliac Gentium jure; efficereque ut fit alterius: id quod poreft optimè Refpublica facere; non fecùs ac efficere poteft, ut venatio aliqua illicita fit, qux, ftando in folo jure naturali ac Gentium, effet licita, ut difp.43. oftenfum eft. E pela mefma razaó fe ha de dizer o mefmo das Minas, ainda que foffem achadas em Terras de Particulares.

E quando naó baftaffe efta razaó, que certamente he forçofa; o Cardeal de Lugo in tractatu de Juftitia \& Jure tom. $I_{\text {. }}$ difp.6. fect. Io.n. 108. moftra, que El-Rey póde refervar parafi as Minas (ainda que fe achem em Terra de Particulares) por modo de tributo, \& tributo muito bem pofto, mandando, que fe lhe pague algúa parte do que fe tirar dellas, para os gaftos da Republica. Et de facto (diz) jure humano folent hujufmodi Mineralia, quoad aliquam faltem partem

- maiorem, vel minorem, Principi applicari; quoad aliam verò inventori : quod quidem fieri potuit, vel quia ab initio agri eâ lege fingulis in ea Provincia diftributi fuerunt, ut Mineralia Principis difpofitioni refervarentur, ut vult Vafquez de Reftitutionecap.5.5.4.dub.2. n. 17.vel certè per modum tribut $i$; ficut poteft Princeps ad fubfidium \& fumptus publicos: alia tributa exigere. Aliunde verò juftificatur non parùm ille modus tributi exeo, quòd cùm Aurum \& Argentum fint potiflim $x$ Reipublic $x$ vires; non expedit, quòd in ijs Princeps ipfe, \& tota Refpublica dependeat à duobus, vel tribus privatis, quifoliea metalla in fuis predijs colligant, ac $\mathrm{K}_{3} \ldots$ collect 


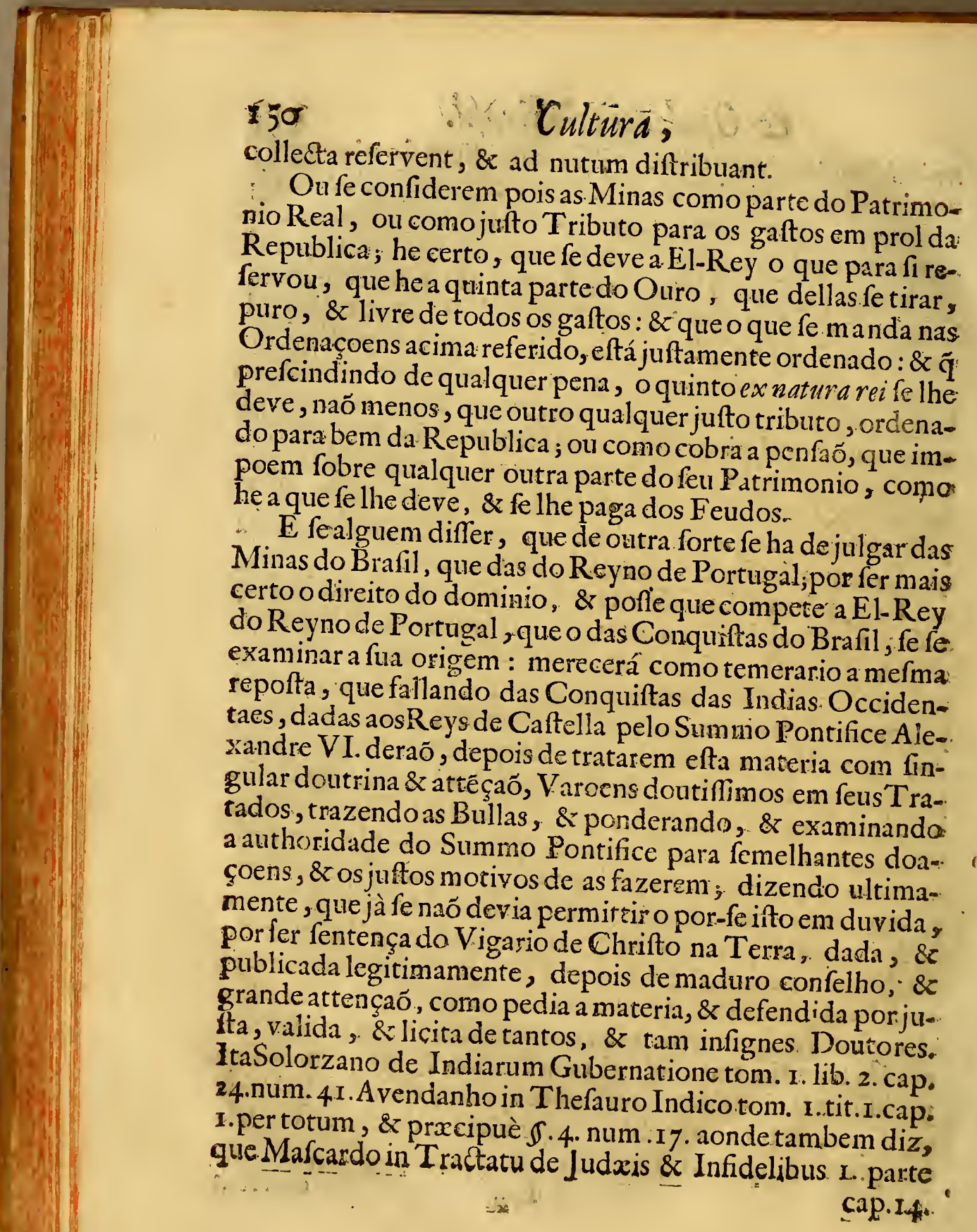




\section{EO Opulencia do Brafil.}

cap. I4. naó duvîda affirmar, que o poder do Papa para tal doaçaó he tam certo, que dizer o contrario parece que tem fabor de herefia: o que o mefmo Avendanho explica em que fentido fe deve entender.

E que mereça a mefma repofta quem differo mefmoda Conquifta doBrafil, ninguem o poderá negar com razaõ:poffuindo os Reys de Portugal pelos mefmos titulos o Brafil, $\&$ as outras Conquiftas, pelos quaes todos effes Authores, Solorzano, \& Avendanho, \& outros doutifima, \& folidifi. mamente provaó o legitimo dominio, \& poffe, que compete aos Reys de Caftella, das Indias Occidentaes, como confta pelas Bullas dos Summos Pontifices Callifto III. Nico. lao V: \& Alexandre VI. que fe acharáó no mefmo cap. 24. de Solorzano defde a pag. 344 . atè a pag.353. \& em todo o Livro 2. do dito primeiro tomo de Indiar.Gubern. que confta de 25. Capitulos; \& no terceiro, que confta de 8. aonde com fingular erudiçaó prova unicamente ajuftiça, com quefe acquirio, \& fe conferva o dominio, \& poffe deftas Conquiftas.

E fallando o mefmo Solorzano, no fegundo tomo lib. 5.' cap.r.em particular das Minas, \& dos Metaes, que dellas fe tiraó, num. 19. diz, que affim nas Indias, como em qualquer

- outra parte pertencé ao Direito de El-Rey, como feu Patrimonio, \& parte do feu fupremo dominio, quer fe achem en lugar publico, quer em Terras, ou Fazendas deParticulares: de forte, que nunca fe entendem comprehendidas nas datas $\&$ doaçoens, ainda que geralmente feitas . fe fe naó fizer ef pecial mençaó dellas. E para confirmar o que diz, traz vin te \& quatro Authores, que tratâraó de Regalibus, de Me tallis, \& de Jure Fifci; ou interpretâraó o Capitulo r. Qư fint regalia, ou a Ley 2. Cod.de Metallar. Diz tambem num. 20. que por razaó dos gaftos, que faó neceffarios, para tirar os Metaes das Minas deftas Conquiftas, contentaó-fe os Reys

$$
\mathrm{K}_{4} \ldots \text { com }
$$




\section{5}

\section{Cuilurs,}

com que fe lhes pague a quinta parte do Metal, que fe tirar. prohibindo ufar delle atè naó fer marcado có o cunho Real, para que confte, que fe pagou a quinta parte. E porque podia haver duvida, fe efta quinta parte de Metal fe havia de entender como vem da Terra naó limpo, \& fe fe haviaó de comprehender nella os gaftos, ou fe fe havia de dar livre deI les; traz no num. I6.a ordem de E1-Rey de 1504 . que decidio ambas as duvidas por eftas palavras : El quinto neto, y fin defcuento de coftas, puefto en poder del nueftro Teforero, o Re. eeptor: que heo que tambem diz a Ordenaçaó de Portugal tit.34. do Livro 2. Depois defundido, Eapurado, paguemo quinto em Jalvo de todos os cuftos.

14: Nota mais Solorzano num.27. do dito cap. r.de Livro 5 . que quando fe falla de frutos da Terra, fe entendem tambeni os Metaes: allegando para iffo a Joaó Garcia de expenfis cap. 22.n.4.7. Lazarte de Gabellis cap. I9.num.59.Barbofa in dicto S: Si vir, L.Divortio ff. foluto matrimonio, Marquech.. de divifione bonorum lib.2.cap. I I. num. 23. \& feq. Cabedo decif. 8 I. num. 2. parte 2 . Gilken de expenfis metallorum in $\mathrm{L}$. Certum Cod.de rei vendicat. cap.5.pag. 722 : Farinac.quxft. Io4.num. 62.\& 63. Tufch. verbo Miner a, concl. 237. \& verbo Praventio, aonde trata de como as Minas, de quemquer que fe occupem, fempre paffaó com fua obrigaçaó. Nxvius in Syftem. ad L. 2. Cod. de Metallar. Pancirolus in Thefaur. lib.3.cap. 3 I. pag. 2 14.327.82 372. Marfil.fingul.53 1. \& Menoch.conf.798. a num.16. E que confequentemente, como os outros frutos da Terra, eftaó fujeitos ao dizimo, que os $\mathrm{Pa}$ pas. :oncedèraó aos Reys de Portugal, \& aos de Caftella : ut ex L.Cundti Cod.de Metallar.Butrius, \& alij in cap. Pervemit de decimis, Rebuffus quxft. Io.num.23.\& 24. \& Solora zanode Indiar. Gubern.tom. 2. lib.3. cap. 2 I. num. ro. pofto que os Reys (como diz o mefmo Solorza no) naó tratem de cobrar eftes dizimos dos Mineiros, contentando-fe por ra- 


\section{COpulenciado Braflo}

2aó dos gaftos com que the paguem a quínta parte do ouro, \& prata que tiraó de fuas Minas, que faó parte do feu Patrimonio, \& parte fempre refervada, como eftà dito.

Paffando agora ao outro ponto, en que fe pergunta, fe efta Ley de pagar a El-Rey a quinta parte do Ouro que feitira das Minas, obriga em confciencia: Digo, que a refoluçaó defta duvida depende de tirar húa falfa imaginaçaó de algứs menos attentos, \& accelerados em refolver: os quaes por verem, que efta Ley he acompanhada đa comminaçaó da pena da.perda da fazenda, \& do degredo por dez annos, \& de outras pelonovo Regimento acerca das Minas do Brafil , cuidaó que he Ley meramente penal, \& que como tal naó obriga em confciencia, nem antes da fentençado Juiz, aos tranfgreffores della, conforme o commum fentir dos Theologos, \& Moraliftas, que trataó das Leys, \& em particular das. penaes.

Porèm o.P. Francifco Suarez examinando mais profundamente (como coltuma) efte ponto no 5 . Livro de Legibus cap. 13. à n. 2.refolve, que as impofiçoens, \& penfoens, que fe pagaó aos Reys, \& Principes por coufas fuas immoveis, \& frutos dellas, faó tributos reaes, \&z naturaes, funda * dos em juftiça; porque fe cobraó decoufas proprias dos di-

- tos Principes, aos quaes fe deraó para a fú fuftentaçaớ; \& elles as deraó aos feus. Vaffallos com obrigaçaó delhespagarem eftas penfoens: \& que por iflo as Leys que mandaó pagar eftas penfoens, our tributos, ainda que fe lhes acrecente algúa pena , fem duvida naófe podem chamar, nem faó puramente penaes, mas difpofitivas, \& moraes : affim convo faó as cốvencionaes entre Partes, que para mayor firneza admitten pena entre os Contrahentes, para que fe guarden os contratos, \& as promeffas de fazer, ou de pagar qualquer divida; que aliunde de juftiça fe deva. E que confequentemente eftas - Leys obrigaó em confciencia a pagar taes penfoens, \& tribus- 


\section{4}

\section{Cultura;}

tosinteiramente, \& efpontaneamente, \& fem diminuiças alguma, ou engano, ainda que fe naó peçaó; porque fe devem de juftica cómutativa, que traz comfigo efta intrinfeca obrigaçaó, fe naó houver pacto em contrario. Atéaqui o P. Suarez n.4. loco citoto.

E defte fundamento certiflimo fe infere tambem certamente, que os quintos do Ouro, que fe tira das Minas do Brafil, fe devem a El-Rey em confciencia : \& que a Ley feita para fegurar a cobrança delles, naó he meramente penal ; ainda que traga annexa a comminaçaó da pena contra os tranf. greflores ; mas que he Ley difpofitiva, \& moral, \& que obriga antes da fentença do Juiz em confciencia. Porque fendo El-Rey (como eftà provado na primeira parte deft a queftaó) Senhor legitimo das Minas, por doaçaô, que lhe fez dellas com a Conquifta do Brafil o Summo Pontifice, \& portodos os outros títulos, que traz Solorzano em todo o Livro 2. do 1,tomo de Indiar. Gubern. communs aos Reys de Portugal como aos Reys de Caftella: \& fendo as ditas Minas do Direito Real, \& parte do feu patrimonio , como quaefquer outros bens, que fe lhe deraó para a fua fuftentaçaó, \& gaftos que faz em prol da Republica, \& para a confervaçaó \& aumento da Fè: \& refervando-as para fi em todas as datas, nem dando li. çença de tirar Ouro dellas, fenaaó com condiçaó, que quem. o tirar lhe pague a quinta parte do que tirar, puro \& defeca. do, \& livre de todos os gạtos : \& podendo pertender ifto (prefcindindo dos outros titulos) por jufto, \& bem ordenado Tributo, comoeftá provado có as razoés, \& authoridade de tậtos Doutores acima allegados : claro eftá, q́ ẹta obrigaçaó eftà fúdada em juftiça cómutativa, como a de quaefquer outros pactos, \& promeffas de qualquer outro jufto contrato, $q$ coftưmaổ admittir os contrahentes em fuas convençoens : \& que ainda que a Ley naó acrecentaffe pena aos transgreffores, fempre deviaoó pagar eltes quintos, por fer obrigaçaố intrin? feca 


\section{\& Opulencia do Brajl.}

feca: \& que oporlhe a pena, he para facilitar mais a cobrança do q́ fe lhe deve; \& naô para fazer hủa Ley meramentepenal.

Nam adjectio ponæ (diz Suarez n. ro.) non tollit obligationem, quam eadem lex, pracife lata fine pona, induceret in confcientiâ : ergo licèt illi addatur pœna, obligat per fead tributum perfolvendum, vel reftituendum (fi contra juftitians non fit folutum ) abfque ulla condemnatione, vel fententia, etiamfi tunc nemo obliget ad pøenx folutionem ante fententiam, juxta generalem doctrinam datam de lege ponali. E declarandoifto mais diz, que efta Ley he mifta ; ou quafi compofta de tributo; \& de pena; \& que fe ordenaó a diverfos fins a impofiçaố da penfaó ou tributơ, \& a pena , que fe lhe acrecenta: porque o tributo fe ordena á fuftentaçaô de E1-Rey, ou a fatisfazer á obrigaçaó natural, que tem os Vaf. fallos de dar jufto eftipendio a El-Rey', que trabalha em prol da Republica: \& a pena feordena a quéfe cumpra efta obrigaçaô, \& fe caftigue quem a naó comprir Łomo deve: $\log$ o ainda que o tributo, ou penfaó feja jufta, \& adequada ao feu fim, \& a obrigaçaó fique inteira; juftamente fe lhe acrecenta a comminaçaó da pena, \& juftamente fe executa, fe bouver culpa, alem da inteira cobrança do tributo. Affim co. mo nas penas, que de cómurm confentimento fe poem pelos - contrahentes emalgújufto contrato, fe póde juftamente obriv gar o violador da promeffa feita no contrato a q́ pague a dita pena, alem do intereffe, \& dano, q́ da tranfgreffá fe feguio. $\mathbb{E}$ diz, que omefmofuccede no noflo cafo: porque fe faz co. mohum contrato entre El-Rey, \& os Vaffallos, para ques El-Rey os governe, \& os Subditos o fuftentem com os tribu: tos, \& penfoens. E para fegurar que fe paguem, póde acr centar-felhe a.pena'; a qual naó diminua a força, \& obriga ȩaó do contrato; mas firva de hữa nova coacçaó, para que os Subditos paguem oque por juftiça lhe devem. Atè aqui o P. Suarez no dito cap.I3.n. $1 O_{3}$

Eifto 


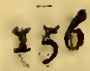

\section{Culturir ;}

E ifto parece, quie baftava para moftrar que os quintos do Ouro, que fe tira das Minas do Brafil, fe devem em confcien. cia, \& antes da condenaçaó, ou fentença a El-Rey Noffo Senhor de juftiça, \& naó por húa Ley meramente penal, comoalguns erradamente imaginaó. Acrecentarey porèm outros motivos para eftabelecer mais efta Refoluçaô. E feja o primeiro, que cfta Ley dos quintos (como advertio Avendanho in Thefauro Indico tom.r.tit. 5.cap.8.n.43.) he muito racional, pela razaó, que traz Molina difp. 5 6.de Juft. \& Jure, $\delta$.ult. \& vem a fer : porque eftá poftoem razaó , que o Principetenha alguma parte mais, que os outros particulares em coufas de preço fingular, como tem em outros bens; ainda quando pareceria fer melhor dallas ao publico. E afimm, faltando os Parentes atè certo grao, os bens dos que morrem abinteftato vaó ao Fifco Real: \& em pena de alguns crimes, lograEl-Rey de tal forte os bens confifcados, que fe alguen por Parente, ainda que muito chegado do Reo, os tiraffe ao Fifco, peccaria contra a juftiça, com obrigaçaó de os reftituir. Logo quanto mais fe ha de dizer o mefmo, quando o rèfervar os quintos do. Uuro fe ordena naó fómente á fuften. taçaó de EI-Rey, mas tambem aos gaftos ém proveito da Republica, \& para a confervaçaô, \& aumento da Fé; fican. do aos Mineiros o mais do Ouro, de que fe tiraó os quintos? ,

Segundo. Porque Filippe II. Rey de Caftella, depois: de ter ouvido o parecer dos Theologos, \& Confelheiros d $x$ India, efcreveo refolutamente ao Vifo-Rey do Perú o Conde. de Villar no anno de 1584.defta forte: $\Upsilon$ pudiera yo cobrar enteramente el quinto de todo ello: (a faber; do Ouro, \& Prata. lavrados) y las Perfonas, quele deben, eftan.obligad as en con ciencia a mé lo pagar. O que naó diria de fua cabeça, contra o parecer dos ditos Theologos, \& Confelheiros, fe aflim o naó tiveffem entendido, como refere Avendanho no dito cap. 8. n. 44. \& traz logo em confirmaçaó difto a Ley de Portugal pelá 


\section{¿o Opulencia do Brafl.}

pela qual (como diž o P. Rebello) fe devem os quintos a ElRey, antes da condenaçaó ou fentença. Diz mais Avendanho em prova de que fe devem os quintos em confciencia, que affim o tem mais de vinte Authores que allega : entre os quaes faó Vafquez, Molina, Liggo, Rebello, Azor, Leffio, Caftilho, Fragofo, \& outros quinze, todos da mefma opiniaó. E dealguns quero citar as palavras, para que melhor confte da verdade, \& da authoridade das Peffoas, que affim fentem.

Vafquez in tradt. de Reftitutione cap.5.5:4.n.30.ait : Ar bitror, quòd prædictx leges non fundentur in prefumptione, nec poenales fint: \& ita nullà expętatâ fententiâ funt obfervandx. Et n. 29. citat Covarruviam, Caietanum, \& Navarrum ita fentientes:

Lugo tom. I. de Juftitia \& Jure difp.6.fect. I r.n. I 3 r.diz: Alix autem leges, qux ponales non funt, potuerunt quidem. transferre dominium in Fifcum: $: \&$ ideò videntur in confcientia obligare ante omnem fententiam judicis.

Molina dicta difp.5 6.de Juftitia \& Jure 5 .ult.ibi: In interiori, dexterioriforo.

Terceiro. Porque do Ouro, \& da Prata fe deve pagaro Dizimo, do mefmo modo que dos outros frutos da Terra, - como eftá provado acima con os Authores que traz Solorzano tom. 2. lib. 3.cap. 2x. n.Io. \& o prova tambemo P.Suarez tom. r.de Religione lib. r. de divino cultu cap.34.n.3. \& 6.8 o P.Tancredi tract.r.de Religione lib.2. difp.In. n. . ex omniumméte: $\&$ fe infere ex generali difpofitione in cap. No eft, de decimis, ubi illa habentur verba:- De omnibus bonis decime funt miniftris Ecclefie tribuende: \& ex cap. Tranfmifla, \&zexcap: Tua nobis. Tendo pois os Summos Pontifices dado os Dizimos do Brafil, \& de outras Conquiftas aos Reys de Portugal, pelas defpezas quefaziaó, \& fazem nas mefnas Conquiltas, \& pelosoutros motivos, q̣ allegaó em fuas Bul- 


\section{8 \\ Cultuirá,}

las (o que podiaổ fazer, "\& de facto o fizerao a outros Reys \& Principes, pelas razoens, \& authoridades, que traz eruditamente Solorzano, com as mefmas Bullas, tom. 2.de Indiar.Gubern. lib. 3. cap. I.) fegue-fe; que tamben fe lhes deraó, \& fe thes haô de pagar os Dizimos do Ouro, \& Prata, que das minas do Brafil fe tirarem : \& que affim eftes, como os Dizimos dos outros frutos da Terra fe lhes devé em confciencia. E que fendo as Minas dos Reys, attentando aos $\mathrm{ga-}$ ftos, que fe fazem em tirar os Metaes, naó tratem de cobrar o Dizimo, \& fecótentem com a pénfaó, ou tributo do Quinto; naô fe podem dizer rigorofos; mas antes benignos, como notou Avendanho no lugar citado a .45 .com Fragofo tom. I.pag.265.S.Alijaddunt.

De tudo ifto fe fegue, que o dizer que os Quintos dó $\mathrm{O}$ us ro fe devem a El-Rey em confciencia, he a opiniaó verdadei$\mathrm{ra}$.mais provavel, \& mais fegura, aflim pelos motivos intrinfecos dos feusfundamentos, particularmente pelos quetraz o P. Suarez acima referidos; como pelos extrinfecos da allthoridade dos Doutores allegados, que faó Theologos de gran de doutrina, \& Religiaô: deixando a opiniaó contraria muito duvidofa, múito fraca, \& nada fegu ra. E que os Officiaes deputados por El-Rey á cobrança dos Quintos, \& a cuwhar o Ouro, tem obrigaçaó grave em confciencia, de fazer bem, \& fielmente o feu oflicio : \& que naó podem diflimuk lar os gravifimos prejuizos, que fe fazem ao Patrimonio Real, defraudado por culpa delles, de muito lucro ; recebendoeftipendió do mefmo Rey, que tem a fua tençaó bem fundada, para que com fidelidade façaó feu officio. ItaAven daphon. 48 .

Oqual porèm n.56. he de opiniaoó, que a prohibiçaó de negociạ com Ouro em pó, naó obriga em conf́ciencia , como obriga a Ley de pagar os Quintos ' $:$ mas que o dito Ouro em pó pâfra com a meluna obrigạaó de fer quintado a quem $\therefore$. quer 


\section{OOOpulenciaido Brafl.}

qquer que vay, até fe fatisfazer a efta intrinfeca obrigaçaô. E com ifto mais fe confirma o que eitá dito da Ley dos Quintos, por fer difpofitiva, \& penal : porque em quanto he difpofitiva do que fe deve de juftiça a El-Rey, que faó os Quintos, obriga em confciencia : \&.em quanto he penal, faz que a pena dos transgreffores naó fe deva em confciencia, fenaô depois da fentença. Em húa palavra: o Quinto fempre fe déve de juftiça; \& a perda dafazenda, \& o degredo, tó poft fententiam.

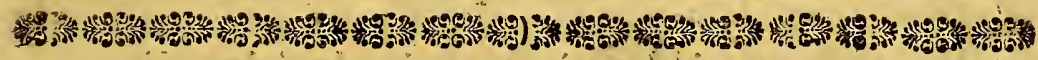

\section{A P I T U L O X.}

Roteiro do caminbo da Villa de Saó Paulo paras as Minas Geraes, Go para o Rio das. Velbas.

Aftaó cómumme nte os Pauliftas derde a Villa de $\mathrm{S} a$ o

I Paulo até as Minas Geraes dos Cataguâs pelo menos - dous mezes : porque naó marchaó de Sol a Sol, mas até o més yo dia ; \& quando muito até húa, oư duas horas da tarde : afo fim para féarrancharé, como para teré tépo de defcançar, \& de bufcar alguma caça, ou peixe, aonde o ha, mel de pao; \& outro qualquer mantimento, E defta forte-aturaócom tam grande trabalho:-

O Roteiro do feur caminho defde a Villa dè Saó Paulo até a Serra de Itatiaya, aonde fé divide em dous, hum para as Minas do Coatê, ou Ribeiráo de Noffa Sentiora do Carmo, \& do Ouro Preto; \& outro para as Minas doRio das Ve. thas; he ofeguinte, em que fe apontaó os poufos $j$ : paragens $\therefore$....

dodit: 
do dito caminho, com as diftancias que tem, $\&$ os dias que pouco mais ou menos fe gaftaó de hũa Eftalagem para outria, em que os Minẹiros poufaó, \& fe he neceffario def́cançaó, \& ferefazem do que haó mifter, \& hoje fe acha ent taes paragens.

No primeiro dia fahindo da Villa deSaó Paulo vaó ớdinariamente a poufar em Noffa Senhora da Penha, por fer (como elles dizem ) o primeiro arranco decafa : \& naó fá́ mais que duas legoas. dia.

Dahi vaó à Aldea de Tacuaquifetûba, caminho de hum.

Gátaố da dita Aldea atè a Villa de Mogî dous dias.

De Mogî vaó ásLarangeiras, caminhando quatro ou cincodias atèo jantar.

Das Larangeiras atè a Villa de Jacarey hum dia até ás tres horas.|

De Jacarey até a Villa de Taubatê dous dias até o jantar.

De Taubatê a Pindamonhangâba, Fréguezia de Notra Sen hora da Conceiçaó, dia \& meyo.

De Pindamonhangâba até a Villa de Guiratinguetâ cinco'ou feis dias atè o jantar:

De Guiratinguetâ até o Porto de Guaipacarê, aonde ficaố as Roças de Bento Rodriguez, dous dias atè o jantar.

Deftas Roças atè o pé da Serra afamada de Amantiquîra, pelas cinco Serras muito altas, que parecem os primeiros Muros, que o Ouro tem no caminho, para que naó cheguem lá os Mineiros, gaftaó-fe tres dias atè o jantar.

Daqui começaó a paffar o Ribeiro, que chamaố Paffavinte, porque vinte vèzes fe paffa ; \& fe fóbe ás Serras fobreditas: para paffar as quaes, fe defcarregaó as Cavalgaduras, pelos grandes rifcos dos defpenhadeiros, que fe encontraó: \&anịm gaítaó dous dias em paffar com grande difficuldade eftas Serras; \& dahife defcobrem muitas, \& apraziveis ar- 


\section{¿o Oputencia do Brajit:}

vores de Pinhcens, que a feu tempo daó abundancia delles para ofuftento dos Mineiros, como tambem Porcos monte. zes, Arâras, \& Papagayos.

Logo paffando outro Ribeiro que chamaó Paffa-trinta , porque trinta \& mais vezes fe paffa, fe vay aos Pinheirinhos: lugar affim chamado, por fer o principio delles: \& aqui ha Roças de Milho, Aboboras. \& F Feijaó, que faó as Lavouras feitas pelos defcobridores das Minas, \& por outros, que por ahi querem voltar. E fó difto conftaó aquellas; \& outras Roças nos caminhos, \& paragens das Minas : \& quando muito, tem de mais algumas Batatas. Porèm em algumas dellas hoje acha-fe creaçaó de Porcos domefticos, Gallinhas, \& Frangãos, que vendém por alto preço aos Paffageiros, levantando-o tanto mais, quanto he mayor a neceffidade dos que paffaó. E dahi vem o dizerem, que todo o que paffou a Serra de Anantiquîra, abi deixou dependurada, ou fepultada a confciencia.

Dos Pinheirinhos fe vay á Eftalagem do Rio Verde, en oito dias, pouco mais, ou menoś, ate o jantar: \& efta Eita la gem tem muitas Roças, \& Veridas de coufas comeftiveis, fem lhe faltar o regalo de doces.

Dahi caminhando tres ou quatro dias, pouco mais, ou menos; atè o jantár, fé dá na afamada Bóa Vifta; a quem bem fe deo efte nomá, pelo que fe defcobre daquelle Monte; que parece hum Mundo novo, muito alegre : tudo cam po bem eftendido, \& todo regado de Ribeiroês, hunsmayores que outros; \& todos com feu matto, que vay fazendo fombra; com muy to Palmito, que fe come, \& $\mathrm{Mel}$ de pao, medicinal, \& goitofo. Tem efte Campofeusaltos, \& baixos ; porém moderados: \& por ellefe caminha com alegria; porque tem os olhos, que ver, \& contemplar na profpectiva do Monte Caxambû, que fe levanta ás nuvens com admiravel altura.

Da Boa Viftafe vayá Eftalagem chamada Ubay, aonde

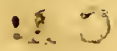




\section{2}

\section{Cultura,}

tambem ha Roças: \& feráó oitodias de caminho moderado atéo jantar.

Do Ubay, em tres ou quatro dias vab ao Ingay.

Do Ingay, em quatro ou cinco dias fe vay ao Rio Gran: de; o qual quando eftá cheyo, caufa medo, pela violencia com que corre: mas tem muito peixe, \& Porto com Canoas; \& quem quer paffar, paga tres vintens : \& tem tambem perto fuas Roças.

- Do Rio Grande fe vay em cinco ou feis dias ao Rio das Mortes, affim chamado pelas q́ nelle fe fizeraó: \& efta he a principal Eftalagem, aonde os.Paffageiros fe refazem, por chegarem jà muito faltos de mantimentos. E nefte Rio , \& nos Ribeiros, \& Corregos, que nelle daó, ha muito Ouro, \& muito fe tem tirado, \& tira: \& o lugar he muito alegre, \& capaz de fe fazer nelle morada eftavel, fenaó foffe tam longe do Mar.

Defta Eftalagem vaóem feis ou oito dias ás Plantas de Garcia Rodriguez.

E daqui, ein dous dias chegáoá Serra de Itatiâya.

Defta Serra feguem-fe dous caminhos: hum, que vay a dar nas Minas Geraes do Ribeiraó de Noffa Senhora do Carmo, \& do Ouro Preto; \& outro, que vay a dar nas Minas do Rio das Velhas : cada hum delles de feis dias de viagem. E. defta Serra tambem começaó as Roçarias de Milho, \&r. Feijaó , a perder de vifta, donde fe provèm os que afifitem, \&s la vraó nas Minas. 


\section{Co Opulencia do Brafi.}

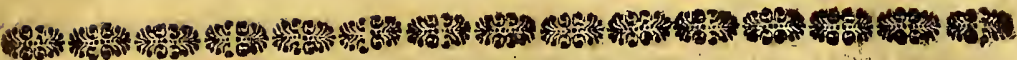

$$
\text { C A P I T U L O XI. }
$$

Roteiro do Caminho velbo da Cidade do Rio de faneiro para as Minas Geraes dos Cas: taguâs, छั do Rio das Velhas.

Th Menos de trinta dias, marchandode Sol a Sol, po dem chegar os que partem da Cidade do Rio de Janeiguir efta marcha, por fer o caminho mais afpero, que o dos Pauliftas. E por relaçaó de quem andou por elle em companhia do Governador Artúr de Sá, he o feguinte. Partindo aos 23.de Agofto da Cidade do Rio de Janeiro foraó a Paratijs. De Paratijs a Taubatê. De Taubatê a Pindamonhangâba.De Pindamonhangâba a Guaratingaetấ. De Guaratingaetâ ás Roças de Garcia Rodriguez. Deftas Roças ao Ribeiraó. E do Kibeiraó com oito dias mais de Sol a Sol chegâraó ao Rio das Velhas aos 29. de Novembro: havendo parado no caminho oito dias em Paratijs; dezoito em Taubatế; dous em Guaratingaetâ ; dous nas Roças de Garcia Rodriguez ; \& vinte \& feis no Ribeiraó; que por todos faó cincoenta \& feis dias. E tirandoeftes de noventa \& nove , que fe contaó defde 23:de Agofto até 29. de Novèmbro; vieraó a galtar nelte cą8 minho naó mais que quarenta \& tres dias. 


\section{Culturas a}

ำ연

\section{A,P I T U I O XII.}

Roteiro do Caminbo novo da Cidade do Riode fa: neiro para as Minas.

D Artindo da Cidade do Rio de Janeiro por terra com gente carregada, \& marchandoá Paulifta, a primeira jornada fe vay a Irajá : a fegunda aoEngenho doAlcaide Mór Thomé Correa : a te rceira, ao Porto do Nóbrega no Rio Iguaçû , onde ha paffagem de Canoas, \& Saveiros: a quarta; ao Sitio, que chamaó de Manoel do Couto.

Equem vay por mar em embarcaçaó ligeira, em hum dia fe poem no Porto da Freguezia de Noffa Senhora do Pilar: $\&$ em outro, em Canoa, fubindo pelo Rio Morobaî acima , ou indo por terra, chega pelo meyo dia ao referido Sitio dó Couto.

Defte fe vay à Cachoeira do Péda Serra, \& fe poufa em ranchos. E daqui fe fobe à Serra, que faó duas boas legoas: $\&$ decendo o cume, fe arrancha nos Poufos, q́ chamaó Frios. No dito cume faz hum Taboleiro direito, em que fe póde formar hum grande Batalhaŏ : \& em dia claro, he Sitio bem fermofo; \& fe defcobre delle o Rio de Janeiro, \& interramen: té todo of eu Reconcavo.

Dos Poufos Frios fe vay á primeira Roça do Capitaó Marcos da Cofta : \& della em duas jornadas á fegunda Ro: ça, que chamaô do Alferes.

Da Roça do Alferes, em húa jornada fe vay ao Pao Gran: de, Roça que agora principia, \& dahi fe vay ao poufar no matto ao pè de hum Morro, que cha maó o Cabarû. - 15 Defte 


\section{Epulenciado Brafil.}

165

Defte Morrofe vay ao famofo Rio Paraîba ; cuja paffagem he em Canoas. Da parte dàquem, eftá hũa venda de Garcia Rodriguez, \& ha baftantes Ranchos para os Paffageiros: \& da parte dalèm, eftà a Cafa do ditó Garcia Ródriguez, com larguiffimas Roçarias.

Daqui fe paffa ao Rio Paraibûna em duas jornadas: a primeira no matto; \&z a fegunda no Porto, onde ha Roçaria, \& venda importante, \& Ranchos para os Paffageiros de húa, \& outra parte. He efte Rio pouco menos caudalofo, que o Paraîba : paffa-fe em Canoa.

Do Rio Paraibûna fazem duas jornadas á Roça do Contrafte Simaó Pereira : \& o poufo da primeira he no matto. $\mathrm{Da}$ Roça do dito Simaó Pereira fe vay á de Mathias Barbofa: \& dahià Roça de Antonio de Araujo : \& deftaà Roça do $\mathrm{Ca}$ pitaō Jofeph de Soufa; donde fe paffa à Roça do Alcaide Mór Thomè Correa. Da Roça do dito Alcaide Mór fe vay a hũa Roça nova do Azevedo: \& dahi à Roça do Juiz da Alfandega Mànoel Correa : \& defta à de Manoel de Araujo. Eem todas eftas jornadas fe vay fempre pela vizinhançado: Paraibuna.

Da Roça do dito Manoel de Araujo fe vayá outra Rocinha do mefmo.

Defta Rocinha fe paffa à primeira Roça do Senhor Bifpo: \& dahi à fegunda do dito.

Da fegunda Roça do Senhor Bifpo fazem húa jornada pequena ä Borda do Campo à Roça do Coronel Domingos Rodriguez da Fonfeca?

Quem vay para o Rio das Mortes, paffa defta Roça à de Alberto Dias : dahià de Manoel de Aratijo, qụe chàmaó da Refaca : \& defta áPonta do Morro, que he Arrayal baftante, com muitas Lavras, donde fe tem tirado grande copia de ouro: \& ahi eftà hum Fortim, com trincheiras, \& foffo, que fizeraóos Emboabas no primeirolevantamentón. Defte lugar 


\section{6 \\ Cultura,}

fevay jantar ao Arrayal do Rio das Mortès.

- E quem fegue a eftrada das Minas Geraes; da Roça fobre dita de Manoel de Araujo da Refaca do Campo, vay à Roça, que chamaó de Joaó Bautifta : dahi à de Joaó da Silva: Cofta : \& deftaá Roça dos Congonhas junto ao Rodeyoda Itatiaya: da qual fe paffa ao Campo do Ouro Preto, onde ha varias Roças; \& de qualquer dellas he húa jornada pequena 20 Arrayal do Ouro Preto, que fica matto dentro, onde eftaó as Lavras do Ouro.

Todas as referidas marchas farào diftancia de oitenta le. goas, a refpeito dos rodeyos, que fe fazem em razaó dos irititos, \& grandes Morros : \& por rumo de Norte a Sul naó fá mais que dous graos de diftancia ao Rio de Janeiro: porque o Ouro Preto eftà em vinte \& hum graos; ' $\&$ o Rio das' Velhas eftarà em vinte, pouco mais ou menos. E todo o dito. caminho fe póde andar em dez até doze dias, indo efcoteiro quem for por elle.

- Do Campo do Ouro Preto âo Rio das. Velhas faó cinco jornadas, poufandọ fempreem Roças.

รั4

\section{A P I T U L XIII.}

Roteiro do Caminbo da Cidade da Babia para as Minas do Rio das Velbas.

D Artindoda Cidade da Bahia, a primeira poufada he na Cachoeira: da Cachoeira vaóa à Aldea de Santo Antonio de Joaó Amaro: \& dahi à Tranqueira. Aqui divide-fe o caminho: \& tomando-o à maó direita, vaó aos Curraes do Filgúeira longo à nacença do Rio das Raãs.Dahi paffaó ao Cur- 


\section{GOpulencia do Brafil.}

ral do Coronel Antonio Vieyra Lima : \& defe Currál vaó ao Arrayal de Mathias Cardofo.

- Mas fe quizerem feguir o caminho à maó efquerda $\therefore$ che gando à Tranqueira, metem-fe logo no caminho novo, \& mais breve, que fez Joáo Gonçalvez do Prado; \& vaó adian. teaté a nacença do Rio Verde. Da dita nacença vaó ao Cam= po da Garça : \& dahi fubindo pelo Rio acima vaó ao Arrayal do Borba ${ }^{2}$ donde brevemente chegaó às Minas Geraes do Riodas Velhas:

Os que feguîraó o caminho da Tranqueira à maó direita ; chegando ao Arrayalde Mathias Cardofo, vaólongo do Rio de Saó Francifco acima, até darem na Barra do Rio das Velhas : \& dahi, comoeftà dito, logo chegaó às Minas do mefmo Rio.

Mas porque nefta jornada da Bahia huns caminhaó atéo meyo dia, outros até àstres da tarde, \& outros de Sol à Sol: porey a diftaricia certa por legoas deftes dous caminhos $\mathrm{da}$ Bahia para as Minas do Rio das. Velhas, que he a feguinte.

Da Cidade da Bahia atè a Cachoeira doze legoas.

$\mathrm{Da}$ Cachoeira atè a Aldea de Joaô Amaro vinte $\&$ cinco legoas.

$\because$ Da Aldeà de Joáó Amaro até a Tranqueira quarenta \&

- tres legoas.

○. Da Tranqueira caminhando à maó direita até o Ar rayal de Mathias Cardofo cincoenta \& duas legoas.

Do Arrayal de Mathias Cardofo atè a Barra do Rio das Yelhas cincoenta \& quatro legoas.

Da Barrado Riodas Velhas atèo Arrayal do Borba,aonde eftaó.as Minas; cincoenta \& hŭa legoas. E faó por todas, duzentas \& trinta \& fete legoas.

Tomando o caminho da Tranqueira á maó efquerda; $q$ ' da Bahia atè ahi conita de oitenta legoas : faó da Tranqueira atè à nacença do Rio Guararutîba trinta \& tres legoas.

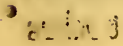
$\mathrm{L}_{4}$

$\mathrm{Da}$ 


\section{8}

\section{Culturä;}

Da dita nacença atèo ultimo Curral do Rio das Velhas: quarenta \& feis legoas.

Defte Curral atèo Bórba vinte \& fete legoas. E faó por todas; cento \& oitenta \& feis legoas.

- Eftecaminho da Bahia para as Minas he muito melhor, que o do Rio de Janeiro, \& o da Villa de Saó Paulo: porque pofto que mais comprido, he menos difficultofo; por fer m:is aberto para as Boyadas, mais abundante para ofuftento, \&mais accommodado para as Cavalgaduras, \& para as cargas.

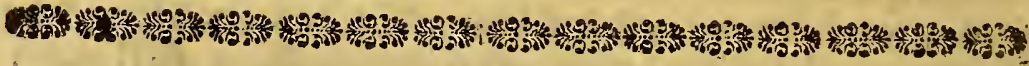

\section{A P I T U L O XIV.}

Modo de tirar o Ouro das Minas do Brafil. E Ribeiros dellas, obfervado de quem. gellas affiftio com o Governador? Artúr de Sà.

D Orey aqui a Relaçaó, que o mefmo Author me mandou, \& he a feguinte. Conforme as difpofiçoens, que: vi peffoalmente nas Minas do Ouro de Saó Paulo, aflim nas Lavras de agua dos Ribeiros, como nas da Terra contigua a elles; direy brevementeo que póde baftar, para que os curiofos Indagadores da Natureza mais facilmen te conheçaó em fuas experiencias, que Terra, \& que Ribeiros poffaóter, ou naó ter Ouro. Primeiramente em todas as Minas, que vi, \&cem que affiftí, notey que as Terras faó montuofas, com Serros ; \& Montes, que fe vaó às nuvens; por cujos centros correndo Ribeiros de baftante agua , ou Corregos mais pequenos, cercados todos de arvoredogrande \& pequeno, em todos 


\section{Opulencia do Brall.}

todos eftes Ribeiros pinta Ouro com mais, ou menos abundancia. Os finaes, por onde fe conhecerà fe o tem, faó, naó terem areas brancas à borda da agua, fenaó huns feixos miudos ; \& pedraria da mefma calta na margem de algumas pontas dos Ribeiros: \& elta mefma formaçaó de pedras leva por debaixoda Terra. Ecomeçando pela Lavra defta, fe o Ribeiro depois de examinado com focavaó faifcou Ouro, he final infallivel, que o tem tambem a Terra: na qual dando, ou abrindo Catas, \& cavando-a primeiroem altura de dez, vinte, ou trinta palmos; em fe acabando de tirar efta Terra, que de ordinario he vermelha; acha-fe logo hum pedregullio, a que chamaó defmonte, \& vem a fer feixos miudos com area, unidos de tal forte com a Terra, que mais párece obra artificial, do que obra da Natureza :-ainda que tambem fe acha at: gum defmonte defte folto, \& naố unido; \& com mais jou menos altura. Efte defmonte rompe fe comalabancas : 2 fe aca fo tem Otro, logo nelle começa a pintar; ou (como diżem) a faifcar algumas faifcas de Ouro na batea, lavando o dito defmonte: Mas ordinariamente, fe pintou benr o definonte; hefinal, que a piçarra terà pouco, ounenhum Ouro: \& di . go ordinariamente; porque naó ha regra fem exceiçaó.

Tirado fóra odefmonte, que às vezes tem altura de mais - de braça, fegue-fe ocaf́alho: \& vem a fer huns feixos mayoFes, \& alguns de bom tamanho, que mal fe podem virar; \& tam queimados, que parecen de chamine: $\mathbf{E}$ tirado efte cafcalho, apparece a piçarra, ou piçarraó, que he duro, \& dà pouco: : efte he hum barroamarello, ou quafi branco,mulito macîo ; \& obranco he o melhor : \& algum defte feacha; que parece talco,oumaracaxeta; a qual ferve como de cama aonde eftà o Ouro. E tomando com almocafres nas bateas: efta piçarra, \& tambem a țerra, que eftà entre ocafcalho, $/:$ vay lavar ao $R$ io : $\&$ botando fóra a terra coma mefina batea, andando com ella à roda dentro da agua pouco a pouco; 0 . 


\section{Iyo Culturats}

Ouro (feo tem) vay ficando no fundo da batea : atè que la vada toda a batea da terra; pelo Ouro, que fica, fe vè de que pintahe a Terra.

Algúa Terra ha, que toda pinta; outra fó em partes : \& a cada paffo fe eftá vendo, queas Catas em húa parte pintaó bem, \& $\mathrm{cm}$ outras pouco, ou nada. Jà fe a Terra tem Veeyro, que he o mefmo que hum caminho eftreito, \& feguido; por onde vay correndo o Ouro; certamente naó pinta pelas mais partes da $\mathrm{Cata}$ \& \& fe vay entaó feguindoo V eeyro atraz do Ouro: \& eftas de ordinario faó as melhores Lavras, quádo - Ouro pega em Veeyros, onde fe encontraó com grandeza; \& he final, que toda a Data da Terra, para onde arremete o Veeyro; tem Ouro. As Catas ordinarias, que fe daó em terra, faó de quinze, vinte, \& mais palmos em quadra; \& podem fer mayores, ou menores, conforme dà lngar a terra. $E$ fe junto dos Ribeiros a terra faz algum taboleiro pequeno, (porque ordinariamente os grandes naố provaó bem) efta he a melhor paragem para fe lavrar. Pofto que o cómum do $\mathrm{Ou}$ ro he eftar ao livè da agua; vi muitas Lavras (\& naó das pe. yórés ) qué naó guardaó efta regra, fenaó que ao Ribeirö hiaó fubindo pelos Outeiros acima,com todas as difpofiçoês, que temos dito, de cafcalho \&c. mas naó he ifto ordinario.

- Atè aqui o que toca às Lavras da'Terra junto da aguia: porém as dos Ribeiros, fe elles faó capazes dé fe lhes poder defviar a agua, fe lavraó divertindo efta por húa banda do mefmo Ribeiro, com cerco feito de paos muy direito, deita. dos huns fobre outios com eftacas bem amarrados, feito em fórma de cano por húa, \& outra parte, para que fe poffa en: tupir de terra por dentro, do modo que aqui fe vè. 


\section{G. Opulencia do Brafa.}

Margens

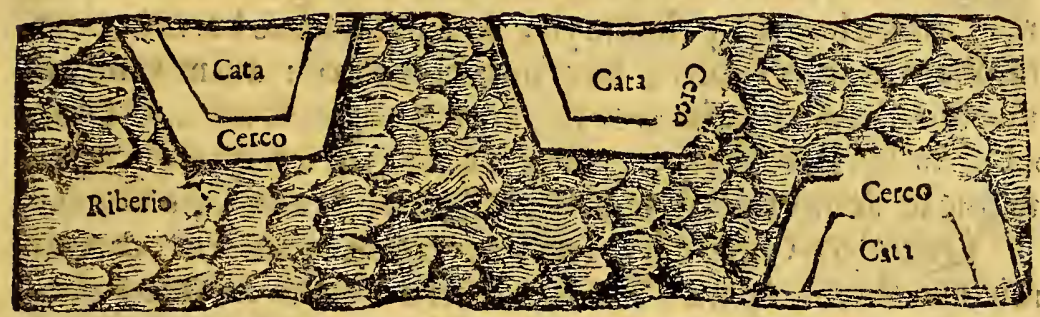

\section{Margens}

Ifto fe entende, quando fe naó póde delviar todo o R ibeiro para outra parte : para o que raras vezes daó. lugar os Serros: Divertida, \& efgotada a agua com as bateas, ou cuyas; fe tira o cafcalho, our feixos grandes, \&x pequenos, que na aguta naó he muy alto, \& fe dá có a piçarra: vé-fe, fe o Oa. ro demanda para a Terra depois de lavada $x$ Cata; \& fe buf: ca a Terra, entrando porella, \& fe vay feguindo, \& abrinào Catas, hūas fobre outras. E ordinariamente fe deve pro. var fempre em primeiro lugar o Ribeiro dentro daMadre an- tes de lavrar na Terra, paraver, fe tem Ouro: porq́fe o tem. quafi fempre o ha de haver em terra com mais, ou menos abundancia. E muitas vezes fuccede (como fe vio nas-mais: das Lavras de C,aburàbucû) que pintando mury pouco na: agua, ou Madre, emmuitas Lavras fóra da aguia fe deo com nuito Ouro:

Por tanto para fe examinar, fe hum Ribeiro tem Ouro, vendo-lhe as difpofiçoens, que temos dito entre a agua; \& 2. Terra, fe dará hum focavaó de fete ${ }_{2}$. ou oito palmos em quadra, atè chegar ao cafcalho, \& piçarra; \& fe faifcar, he final, que em terra, \&na agua ha Ouro: \& pelas pir- 
tas deftés focavoens fe conhecerá , fe faó de rendimento: Nem neftas Minas fe repartem Ribeiros, fem ferem primeire. examinados com eftes focavoens junto da agua. Nos Ribeiros, on de ha area pelo meyo, \& a naó ha nas barranceiras, tambem fe acha Ouro, havendo cafcalho : affim tambem nos Ribeiros; onde ha area por entre fedras, fe acha. O efmeril acha-fe com area preta entre o Ouro : \& em qualquer parte que fe acha efmeril, tendo o Ribeiro cafcalho, ha Ouro.

Quando o Ouro corre em Veeyro, de ordin ario corre direito do Ribeiro para a Terra adentro : \& no mefmoRibeirofe fucceder acharem-le muitos Veeyros, feráó diftantes huns dos outros : \& fuppofto que perto do Veeyro fe ache formaçaô; contudo fó no Veeyro fe acha mais Ouro. Tambem fe achaó muitos feixòs com granitos de Ouro.

Eftas faó algúas das coufas, que fe podem dizer deftas Minas, para que fe pofla por aqui fazer exame em alguns Ribeiros, aonde fe fufpeita, que haverá Ouro. Naó deixarey com tudo de referir aqui tambem oque vi no famofo Rio das Velhas; porque parece fóra de toda a regra do Mineral. Em huma peninfula, que da terra entra no Rio, quafi atè o meyo, em que com as cheas fica toda cuberta de agua, vi lavrar dous Corregos pequenos, júnto da agua; os quaes abrindo-fe com alabancas, eraó todos de hum piçarraó duro, \& claro: \& por ، entre elle fem fe ir lavar ao Rio, foy tal a grandeza do Ouro, de que eftavaó cheyos, que fe eftava vendoem pedaços, \&c granitos nas mefmas bateas. Ebateada houve, em que fe titavạo de cada vez quarenta, cincoenta, \& maisoitavas; fendo as ordinarias, em quanto fe lavraó, de oito, \& mais oita: yas. Ainda que lavrando-fe depois pela Terra adentro na mefima peninfula, foy diminuindo cada vez, mais a pinta; \& foraó logo appareçendo as difpofiçoens todas, que temos dito, de terra, defmonte, cafcalho, \& piçarra; que naó ha regra, comojà diffe, fen exceiçaó: \& anuitas vezes' naó dá com 


\section{\&OOpulencia do Brafil.}

Quro quem mais cava, fenaó quem tem mais fortuna. Tam. bem fe acha muitas vezes húa difpofiçaô de defmonte, que fe chama Tapanhuacanga, q́ val o mérmo q́ Cabeça de Negro, peloteçume das pedras, tam duro, que fá a poder de ferrofe defmancha: \& naó he mao final; porque muitas vezes o caf calho, que fica em baixo, dà Ouro.

Dealgunas particularidades mais deftas Minas, por ferem menos effenciaes, naó fallo: \& porque faóm mais parafe verem, do que para fe efcreverem; \& eftas faó as que baftaó para o intento dos que ou por curiofidade, ou para acertar na Lavra as procuraó.

6e

\section{A P I T U L O XV.}

\section{Noticias para se conbecerem as Minas de Prata.}

D Rimeiraniente pela mayor parte fe achaó as Minas de Prata em terras vermelhas, \& brancas, limpas de arvo. res, \& de poucas hervas: \& fempre fe haó de bufcar no cume dos Outeiros, ou Serros, que he onde arrebentaóas betas a modode paredes velhas, que correm fempre direitas; ou a modo de alicerfes, que eftaó debaixo da terra ; ou como hú marachaó de muitas pedras unidas em roda : \& fe fe achaó muitas juntas, bufque-fe fempre a mus larga, ou a que eftà mais no meyo do Outeiro; Em havendo cavado húa vara, ou braça , feguindo fempre a beta, fe póde fazer experiencia dos generos de Metal, que tiver; porque ha botas, que tem cinco, ou fcis generos de pedras, a que chamaóos Caftellhanos. Metaes. As ditas betas coftumaó ter de largo húa braça, on quatro palmos, outres, ou dous, ou hum. Pela mayor parte entre 
entre a beta fe acha terra de varias cores; \& às vezes tudo he pedra maciça: \& entaó coftuma fer negra, \& branca a dita pedra a modo de feixos : \& quando ha terra entre a pedra pedra, \& terra, tidotem Prata. Efta beta ordinariamente eftà metida entre penhafcó agrefte, \& defde a fuperficie da Terra atè o fundo, fempre vay encaixonada.

A pedra he de varias cores, differente das outras, \& muy alegre: branca, negra, a modo de maracaxeta que fe lança nas cartas, cor de ouro, a marella, azul, efverdeada, parda; de cor de figado, laranjada, leonada: \& ordinariamente tem ocos, onde fe coftuma crear Prata como em cubellos. Outras pedras faó todas prateadas, \& outras com veas de prata : \& fó eftàs fe conhecem logo, que tem prata. Porèm as acima no. meadas, fó quem tem muita experiencia, ou quem a fouber fazer, virà em conhecimento que a tem. Tambem às vezes fe acha húa maracaxeta negra, a qual toda tem prata: $\&$ de ordinario huma livra defta maracaxeta rende duas onças de prata. Pela mayor parte naó ha beta de prata, que junto a ella fe naó ache maracaxeta branca, ou amarella, ou em pedras agreftes, ou em terra.

A todas eftas pedras chamaó os Caftelhanos Metaes : \& a algumas daó eftes nomes. Metal Cobrizo : \& he huia pedra; que tira a verde, muy pezada, falgada ao gofto, eftitica, \& frange os beiços pelo acre do antimonio, \& vitriolo, que tem mifturado. Metal Polvorilha : \& he húa pedra hum tanto amarella; \& he de mais ley, que oacima, \& às vezes para o fundo coftuma dar em prata maciça. Metal Negrilho da primeira qualidade he pedra negra com refplandores de limaduras grofias de ferro : he de pouca ley ; porèm porque fac mifturado com Metal negro da fegunda qualidade, que he com refplandores de area miuda, \& com o da terceira qualidade, que he aquelle que feito pò, a fua area naó tem ref́plandoralguni; he o mellior, \& devéfefazer cafo delle. Metal Roci: 


\section{djOpulencia do Brafll.}

Rocicler he húa pedra negra, como o Metal Negrilho, melhor de area, como po efcuro fem refplandor $: \&$ fe conhece fer Rocicler em que lançando agua fobre a pedra, fe the dà com húa faca, ou chave, como quem a moe, \& faz hum mo. do de barro, como enfanguentado; \& quanto mais córado o barro, tanto melhor he o Rocicler: \& he Metal de muita riqueza, \& facil de fe tirar, \& dando em parte que haja dela. gue aoSerro, naó ha mais que pedir : dà em caixa de barro como lama, \& pedrinhas de todás as cores.

Metal Paco he tambem como o Rocicler, o qual he hưa pedra quafi parda, como o panno pardo, ou defumado, $\&$ muy pezada. Seria eftender-fe muito, fe fe houveffe de pốr feus generos de caixa, de qualidade, \& beneficios;: porque he, \& $\mathrm{fe}$ faz de muitos modos fegundo os generos de Pacos. Porèm fendo a pedra fem golto algum ao maftigar-fe pizada, ferà de boa ley para a fundiçaó, por ter muito chumbo, que ajuda a mefma fundiçaó: \& efte genero de Metal, \& oNegrilho faó os mais abundantes nas Minas , fem fe perderem, nem mudarem ; \& quando muito, mudaó de Pacos a Negrilhos, \& de Negrilhos a Pacos. Metal Plomo Ronco he hüa pedra de cor de chumbo, porèm mais efcura, \& muy dura, \& pezada. He riqueza de fun $\mathrm{iç}_{\mathrm{a}}$ : \& defta pedra affirmaó - alguns, que fazem bólas de bolear os Indios Charruas, que vizinhaó, ou vizinhavaó con os Portague zes na Nova Co. lonia do Sacramerto.

\section{-}

C A. 


\section{6}

\section{Cultura,}

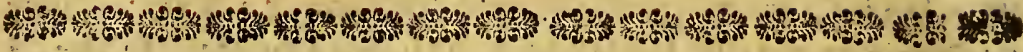 \\ C A P I T U L O XVI.}

\section{Modo de conbecer a Prata, Es de beneficiar. os Metaes.}

E houver lenha (\& melhor he bofta de Gado, por fer mais activo o fogo della) farfe-ha húa fogueira; \& no me. yo dellafe lancem as pedras do genero; que tiver a Mina : \& as deixaráó queimar, até que fe ponihaó vermellias, comofe poem o ferro. E eftando vermelhas, fe lancem em agua fria, cada húa em diverfa parte, parafe conhecer qual das cores tem mais Prata; que logo fe moftrará na agua : porque fe tem Prata, brotaó por toda a pedra cómo cabeças de alfinetes, ou comogrăós de muniçaó.

- Tambem fe podem reconhecer cóm chumbo nefta for- ma.Quando os Metaes faó negros, com pouças veas brancas, (que fe $f_{a} \delta$ muitas faz-fe com azougue) fendo muy pezados fe moeráó, de forte que o graó nıayor fique como o de trigo: \&em húa furna, como as que fe fazem para derreter metaes de Sinos , fe botarâ chumbo, \& fe lhe dará fogo com folle, até que aquelle chumbo fe derreta, \& ponha córado; \& entaó fe lhe botará a pedra moida : a faber, em meya arrobade chumbo fe poderáó beneficiar feis livras de pedra nefta fórma.

Eftando derretido, \& córado o chumbo, fe lhe lançaráó duns livras de pedra, eftendendo-as por cima do chumbo : \& eftando tudo encorporado com o chunbo, a modo de agia 


\section{Opulencia do Brall.}

fórma fe vay lançando a mais terra, atè que fe acabem as feis jivras. E em fe acabando a pedra, ou Metal, fe continue com dar fogo ao chumbo, atè que of fogo o confuma, ou o converta em hum farello, que vay criando por cima; o qual fe irá tirando com a efcumadeira, \& apartando aos lados dovafo, atè que a Prata por ultimo fe difpa de húa teagem , que tem por cima : \& antes que de todoo faça, faz primeiro tres ou quatro acometimentos; como quem abre \& cerra os olhos, a modo de ondas; até que de todofe abre, \& fica a Prara liquida, fem fazer movimentos. E entaó fe pára com o fogo ; \& eftando hum pouco dura, fe mete a efcumadeira por hum lado , \& outro, para a defapegar do vafo, \& fe tiráfóra.

Sequizerem fazer enfayo por azougue, farfe-ha dos Mesaes, que naó forem negros: ou fe forem negros, queimarfehaó primeiro em forno de reverberaçaó, até que felhes tire a maldade de coufas acres, que tem os Metaes, ou pedras negras. E efta queima fe faz, depois de moidos : \& fe algum dos outros Metaes tiver acridades, fe deve primeiro queinar tambem. O que pofto: digo, que todos os Metaes, ou pedras fe devem moer, \& peneirar, de forte que fiquem como farinha de trigo: a peneira ha de fer de panno; \& pezarfe-haó os Metaes. Se forem feis livras, felhes botará hum punhado de fal; \& tudo junto fe molharà com agua, como quem miftura a cal com area. Depois de bem unido, fe faz hum montiśho, de forte que efteja brando com a agua, para que fe encorpore com elle o fal : \& nefta fórma fe deixarà eftar fobre hưa taboa quatro ou cinco dias ao Sol. E paffidos eftes dias, fe desfarà o montinho, \& fe pizarà muy bem aquella terra : \& em hum panno fino de linho fe botaràô duas onças de azougue vivo, \& com o mefno panno fe efpremerà por cima da dita terra, que eftarà efpalhada, \& bem fina: \& junta fe amafM farà 


\section{Cultura,}

farà com a maó, por tempo de hũa hora; \& fe eftiver muy feco, fe molhara com agua, aiè que fique como barro de fa-zer telha.

Depois difto fe tornarà a fazer monte, \& a pollo ao Sol outros tantos dias; no cabo dośquaes, fe ten prata alguma, o moltrarà nelta fórma: \& veni a fer, que o azougue, \& a prata fe converteràó em hum farello branco. E eftando affim, fe The lançarà mais azouge, \& fe tornarà a amaffar, como eftà dito, \& a pollo ao Sol outros tantos dias; \& depois fe torne a molhar, \& amaflar. Ifto feito, fe bote em húa cuya envernizada hum pedacinho daquella terra, do tamanho de húa noz; \& com agua limpa fe irà lavando, atè que fique limpa a area na cuya, para conhecer fe o azougue ha colhido toda a prata: \& fe eftiver ainda com farello, fe lance mais azougue, como acima.

Havendo colhido o azougue toda a prata, jà inaó farà farello na cuya; \& eftarà toda encorporada. Entaó fe lave todo o monte com muito cuidado; \& fe lance em hum panno de linho novo, \& fe efprema : \& aquella bola, que ficar, fe queimarà, atè que fe queime todo o azonge; \& ficarà liquida a prata : \& feconhecerà, fefaóos Metaes de rendimento cu naó.

Se o azouge eftiver frio (o que fe conhecerà, eftando metido dentro como em hum faquinho negro, que de fi mefmo fórma) fe the botarà mais fal,ou Magiftral: \& fe eftiver quente (o que fe conhecerà de eftar muy negro o farello da prata) fe lhe botarà cinza molhada, \& fe mifturarà tudo, como fica dito acima. Alguns dizem, que a fobredita maffa fe ha de revolver, \&z amaffar todos os dias duas vezes, por efpaço de quarentadias; \& que a cada quintal de pedra fe lança hum almude de fal de compàz, \& dez livras de azougue na fórma acima.

Uitl: 


\section{GOpulencia doBrafil.}

Ultimamente daó eftas regras geraes. As Minas de Norte a Sul fixo, fá permanentes. As Minas de Ouro cabeceaó de Oriente a Poente; \& daó em feixo branco, ou negro; ou em barro vermelho, fe faó boas. Naó havendo fal de pedras junto das ferras de Minas de Prata ; he final, que naó faó Minas de permanencia : \& a efte chamaó os Caftelhanos Sal de Compàz. Só à vifta de quem tem experiencia fe podem dar a conhecer fixamente os Metaes; porque ha outros generos. de Pedras como elles, que naó faó de Prata.

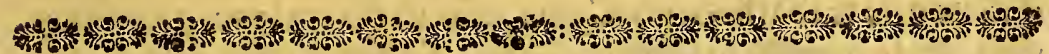

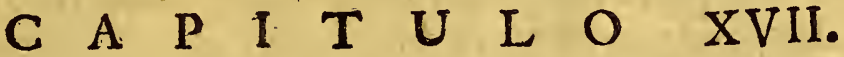

Dos danos, que tem causado ao Brafil a cobiça depois do defcobrimento do Ouro nas

Minas.

T Aó ha coufa tam boa, que naó poffa fer occafiaó de muitos males, por culpa de quem naó ufa bem della. Eatè nas fagradas fe cómettem os mayores facrilegios. Que maravilha pois, que fendo o Ouro tam fermofo, \& tam preciofo metal; tam util para o cómercio humano, \& taó dignơ defe empregar nos vafos, \& ornamentos dos Templos para o culto divino; feja pela infaciavel cobiça dos Homens, con. tinuo inftrumento, \& caufa de muitos danos ? Convidou a Fama das Minas tam abundantés do Brafil homens de toda a cafta; $\&$ de todas as partes: huns de cabedal; \& outros vadios. Aos de cabedal, que tirâraó muita quantidade delle nas $\mathrm{Ca}$ tas, foy caufa de fe haverem comaltivez, \& arrogancia : de $\mathrm{M}_{2}$ anda- 


\section{0 \\ Cultura,}

andarem fempre acompanhados de tropas de efpingardeiros, de animo prom pto para executarem qualquer violencia ; \& de tomar fem temoralgum da Juftiça grandes, \& eftrondófas vinganças. Convidou-os o Ouro a jogar larga mente, \& agaftar em fuperfluidades quancias extriordinarias fem reparo, comprando (por exemplo) hum Negro Trombeteiro por mil cruzados; \& húa Mulata de mao trato por dobrado preço, para multiplicar com ella continuos, \& efcandalofos peccados. Os vadios, que vaó ás Minas para tirar Ouro naó dos Ribeiros, mas dos canudos, en q́ O ajuntaó, \& guardaó os que trabalhaó nas Catas, ufâraó de traiçoens lamentaveis, \& de mortes mais que crieis; ficando eftes crimes fem caftigo ; porque nas Minas a Juftiça Humana naó teve ainda Tribunal, nem o refpeito, de que em outras partes goza, aonde ha Miniftros defuppofiçaó, afilttidos de numerofo, \& feguro Prefidio; \& fó agora poderá efperarfe algum remedio indo là Governador, \& Miniftros. Eaté os Bifpos, \& os Prelados de algumas Religioens, fentem fummamente o naó fe fazer conta alguma das cenfuras, para reduzir aos feus Bifpados, \& Conventos naó poucos Clerigos, \& Religiofos, que efcandalofamente por lá andaó, ou Apóftat tas, ou fuggitíyos. $\mathrm{O}$ irem tambem às Minas os melhores generos de tudo o que fe póde defejar; foy caufa, que creceffem de tal forte os preços de tudo o que fe vende; que os Senhores. de Engenhos, \& os Lavradores fe achem grandemente em-, penhados : \& que porfalta de Negros naố porfaó tratar do Afficar, nem do Tabaco, como faziaó folgadámente nos. tempos paffados ; quceraō as verdadeiras Minas do Brafil, $\&$ de Portugal. Eo peyor he, que a mayor parte do Ouro, que fe tira dis Minas, paffa em pó, \& em moedas para os Reynos eftranhos: \& a menor he a que fica em Portugal, \& nas Cidades do Brafil : falvo o que fe gafta em cordoens, arreca- 


\section{GOpulencia do Braßl.}

$18 \mathrm{x}$

arrecadas, \& outros brinces, dos quaes fe vem hoje carregadas as Mulatas de mao viver, \& as Negras, muito mais qus as Senhoras. Nem ha Peffoa prudente, que inaó confefíe haver Deos permittido que fe defcubra nas Minas tanto Ouro, para caftigar com elle ao Brafil; affim como eftâ caftigando no mefmo tempo tam abundante de guerras, 20 s Europeos com o ferro.

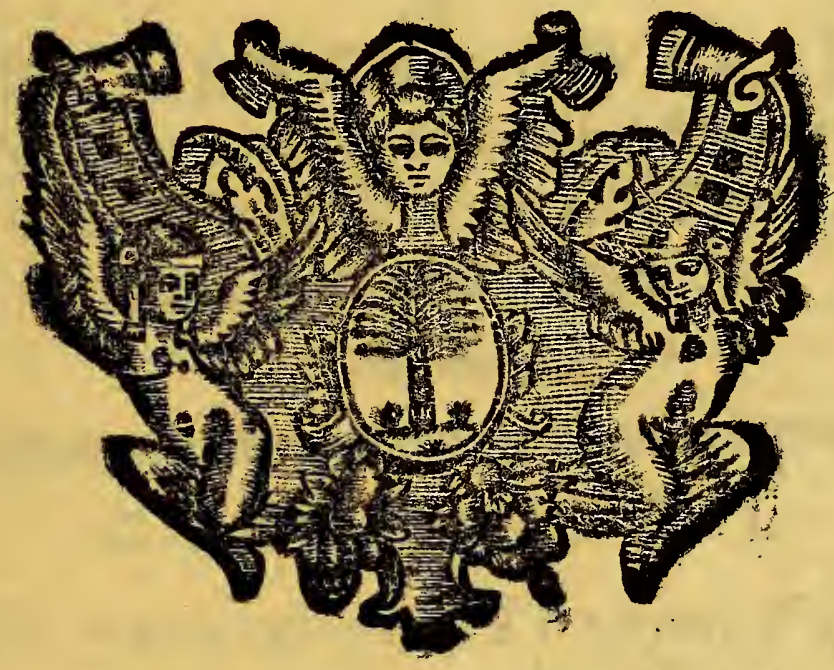


2.

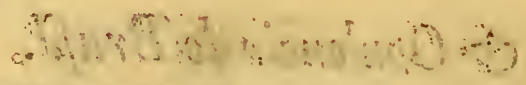

wat A

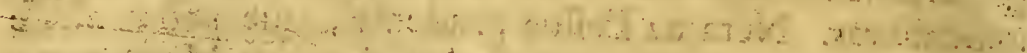
(0) -..t?

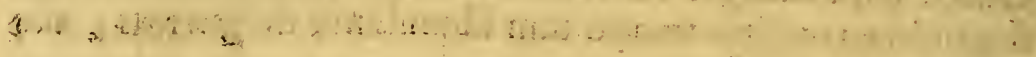

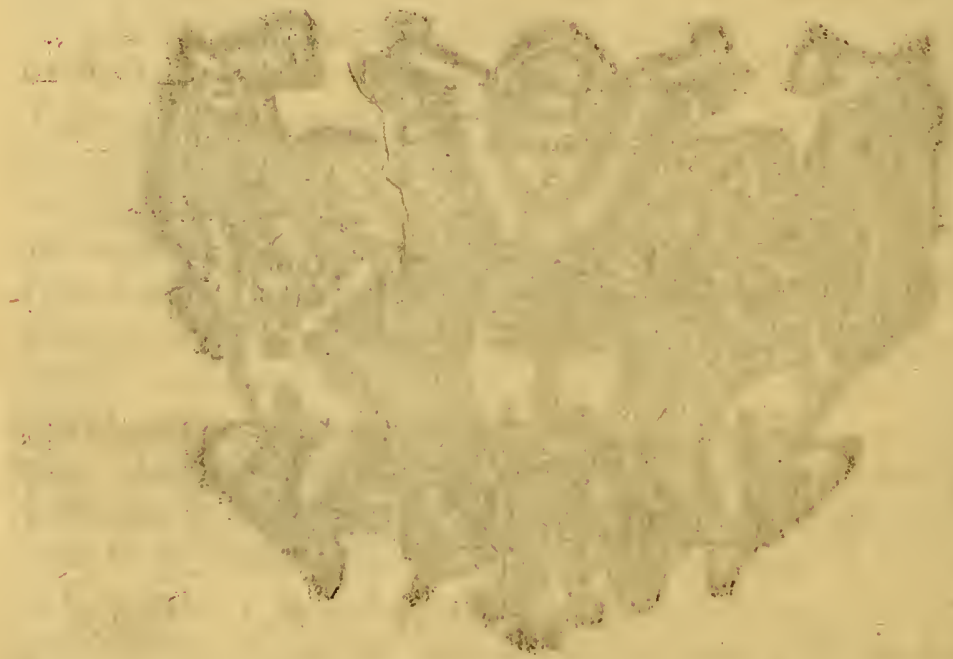




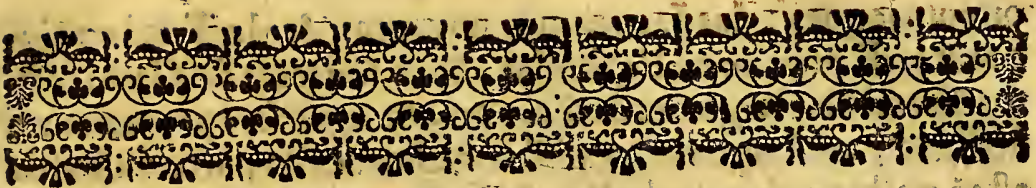

\section{QUARTA PARTE.}

CULTUR

OP VLEN C IA DO BRASIL Pela abundancia do Gado, \& Courama, \& outros Contratos Reaes, que fe remataó nefta Conquiita.

*4:

\section{A P I T V L O I.}

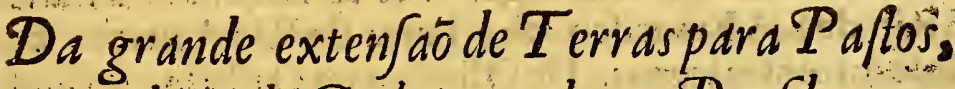
cheas de Gado, que ba no Brafll.

Stende-fe o Certaŏ da Bahia até a Barradó Rio de W. S. Francifco oitenta legoas por Cofta:\& indo para orio cima atè a Barra, que chamaö d'AguaGrande, fica diftante a Bahia da dita Barra cento \& quinze legoas: de Säntunfé centa \& trinta legoas. : de Rodellas por dentro a! $\mathrm{M}_{4}$ oiten. 


\section{4}

\section{Culturis,}

oitenta legoas: das Jacoabinas noventa : \& do Tucâno cin 2 coenta. E porque as Fazendas, \& os Curraes do Gado fe fítuaô aonde ha largueza de Campo, \& agua fempre manante de Rios, ou Lagoas; por iffo os Curraes da parte da Bahiz eftaó poftos na borda do Rio de S. Francifco, na do Rio das Velhas, na do Riodas Raãs, na do Rio Verde, ná do Rio Paramerìm, na do Rio Jacuippe, na do Rio Pojùca, na do RioEnhambûpe, na do Rio Itapicurû, na do Rio Real, na do Rio Vazabarrî́s, na do Rio Serigippe, \& de outros Rios; em os:quaes por informaçaó tomada de varios, que cơrréráo efte Certaó, eftaó actualmenté mais de quinhentos Curraes: \& fón na borda àquem do Rio de Saó F rancifco cento \& feis. E na outra borda da parte de Pernambuco, 'he certo, quie faó muitos mais. E naó fómente de todas eftas partes, \& Rios jà nomeados vem Boyadas para a Cidade, \& Reconcavo da Bahia, \& para as Fabricas dos Engenlió,; mas támbem do RioI Iguąư, do Rio Carainhaem, do Rio Corrente, do Rio Guarậra , \& do Rio Piaguî grande, por ficarem mais perto, vindo caminho direito, á Bahia, do que indo por voltas 2 Pernambuco. E.pofto que fejaó muitos os Curraes dia parte da Bahia, chegaó a muito mayor numero os de Pernambuco; cujo Certaố fe eftende pela Cofta defde a Cidade de Olinda atè o Rio de Saó Francifco oitenta legoas : \&z continuando da Barra do Rio dé Saộ Francifco até a Barra do Rio Aguaçû, contaóo-fe duzentas legoas. De Olinda para Oefte atè oPiaguî, Fréguezia de Noffa Senhora da:Vietoria, cento \& fefferita legoas : \& pela parte do Norte eftende-fe de Olinda ateे o Ceaŕa Merim oitenta legoas.' \& dahi atè o Açû̀ trinta \& cinco; \& até o Cearà Grande oitenta : \& por todas, vem zeftender-fe defde Olinda atè efta parte quafi duzen: tas legoas.

Os Rios de Pernambuco que por terem junto de fr $P_{a-}$ 


\section{\&O Opuleñia do Bráal.}

185

tos competen̂tes, eftaó povoados com Gado (fóra o Rio Preto, o Rio Guaraîra, o Rio Iguaçû, o Rio Corrente, o Rio Guariguaê, a Lagoa alegre, \& o.Rio de Saó Francífcó da banda do Norte) faó o Rio de Cabaços, o Rio de Saó Miguel, as duas Alagoas com o Rio do Porto do Calvo, o da Paraîba, o dos Karirîs, o do Açû́, o do Podî, o de Jaguarî́. be, o das Piranhas, o Payaû, o Jacarê, o Kanindê, odeParnaîba, o das Pedras, o dos Camaroens, \& o Piaguî.

Os Curraes defta parte haó de paffar de oitocentos : \& de todos eftes vaó Boyadas para o Recife, \& Olinda, \& fuas Villas, \& para ofornecimento das Fabricas dos Engenhos defde o Rio deSaó Francifco até o Rio.Grande : tirando os que 'acimz eftaó nomeados defde o Piaguî até a Barra de Tguaçû, \& de Parnaguâ, \& Rio Preto ; porque as Boyadas deftes Rios vaóquali todas para a Bahia, por thes ficar melhor caminho pelas Jacoabinas, por onde pafrö, \& defcançaó. Afin comoahi tambemparaó, \& defcançaó as que ás vezes vem de mais longe. Mas quando nos caminhos re achaó paftos, porque naôf faltáraó as chuvas; em menos de tres mezes chegaó as Boyadas á Bahia, que vem dos Curraes mais diftantes: Porèm fe por caufa da fecaforem obrigadosa $\mathrm{pa-}$ var com o Gado nas Jacoabinas ; ahi o vendem os que o le

- vaó, \& ahidefcançafeis, fete, \& oita mezes, até poder ir à Cidade.

Só no.Rio de Iguaçû̀ eftaó hoje mais de trinta nil Cabe. cas de Gado. As da parte da Bahia fe tem por certo, que pafo. Gaó de meyo milhaó $: \&$ mais de oitocentas mil haó dẹ fer as da parte de Pernambuco; ainda que deftas fe aproveitaô mais os da Bahia, para onde vaómuitas Boyadas, que os Petmbucanos.

A parte do Brafil, , que tem menos Gado, he o Rio de Janeiro: porque tem Curraes fómente nos Campos de Santa Cruz diftantes quatorze legoas da Cidade; nos Campos Novo: 
Novos doRió de Saó Joaó, diftantes trinta ; \& nos Guaita cazes, diftantes oitenta legoas : \& em todos eftes Campos: nạo paffaó de feffenta mil as Cabeças de Gado, que nelles paftaó.

A Capitania doEfpirito Santo fe prové limitadamente da Moribêca, \& dealguns Curraes àquem do Rio Paraîba do Sul.

As Villas de Saó Paulo mataó as Rezes, que tem em fuas Fazendas, que naó faó muito grandes; \& fó nos Campos de Coritíba vay crecendo \& \& multiplicando cada vez mais - Gado.

Sendo o Certaó da Bahia tam dilatado, como temos re. ferido; quafi todo pertence a duas das principaes Familias dá mefrna Cidade, que faó a da Torre, $\&$ a do defunto Meftre de Campo Antonio Guedes de Britto.Porque a Cafa da Torre tem düzentas \& feffenta legoas pelo Rio de Saō Francifco acima à maó direita, indo para o Sul; \& indo do dito Rio para oNorte, chega a oitenta legoas. $\mathrm{E}$ os Herdeiros do Mefre de Campo Antonio Guedes poffuem defde o Morro dos Chapeos atèa Nacença do Rio das Velhas, cento \& feffenta legoas. E neftas Terras, parte os donos dellas tem Curraes proprios; \& parte faó dos que arrendârá fitios dellas , pa. gando por cada fitio, que ordinariamente he de húa legoa, cada anno dez mil reis de foro. E aflim como ha Curraes no Territorio da Bahia; \& de Pernambuco, \& de outras Capitanias, de duzentas, trezentas, quatrocentas, quinhentas, oitocentas, \& mil Cabeças; affim ha Fazendas, a quem pertencem tantos Curraes, que chegaó a ter feis mil, oito mil, dę mil, quinze mil , \& mais de vinte mil Cabeças de Gado: donde fe tiraó cáda anno muitas Boyadas, conforme os tempos faó mais ou menos fávoraveis à pariçaó, \& multiplicaçaó do mefno Gado, \& aos paftosalím nos fitios, como tamberin nos caminhos. 


\section{Ë Opulencia do Brafl.}

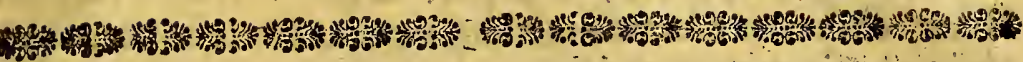

\section{A P I T U L O II.}

Dos Boyadas, que ordinariamente fe tirao cada anno dos Curraes, para as Cidades, Villas,

E Reconcavos do Brafil, afjum para o agougue, como para ofornecimento das Fabricas.

D Ara quefe faça jufto conceito das Boyadas, que fe tiraó cada anno dos Curraes do Brafil, bafta advertir, que todos os Rolos de Tabaco que fe embarcaópara qualquer parte, vaó encourados. E fendo cada hum de oito arrobas, 8 \& os da Bahia, comovimosem feulugar, ordinariamente cada anno pelo menos vinte \& cinco mil , \& os das Alagoas de Pernambuco dous mil \& quinhentos; bem fe vê, quantas Rezes faó neceffarias para encourar vinte \& fete mil \& quithentos Rolos.

Alem difto, vaó cada anno da Bahia para o Reyạo atè cincoenta mil meyos de Sola; de Pernambuco quarenta mil; \& do Rio de Janeiro (naó fey fe computando os que vinhaó da Nova Colonia, ou fóos.do mefmo Rio, \& outras Capitanias do Sul) atè vinte mil : que vema fer por todos; cento: \& dez mil Meyos de Sola.

$O$ certo he, que naófómente a Cidade, mas a mayor pale te dos Moradores do Reconcavo mais abundantes fe fuftentaó nos dias naó prohibidos da carne do açougue, \& da que fe vende nas Freguezias, \& Villas: \& que commúmente os Negros, que fá hum numero muito grande nas Cidades, vi-

verr: 


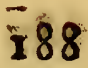

\section{Cultura,}

vem de ferçuras, bofes, \& tripas, fangue, \& mais fato das Rezes: \& que no Certaó mais alto a carne, \& o leite he oordir: nario mantimento de todos.

Sendo tambem tantosos Engenhos-do Brafil, que cada anno fe fornecem de Boys para os carros; \& cs de que neceffitaó os Lavradores de Cannas, Tabaco, Mandioca, Serrarias, \& Lenhas; daqui fe poderà facilmente inferir, quantos haverào mifter de anno em anno, para confervar efte trabalhofo meneyo. Por tanto deixar ifto á confideraçaó de quem ler efte Capitulo, julgo, que ferá melhor acerto, do que affirmar precifamente o numero das Boyadas : porque nem os mefinos Marchantes, "que faó tantos,' \& tam divididos por todas as partes povoadas do Brafil, o podem dizer com cerreza; \& dizendo-o, temo, que naó pareça crivel, \& quie lè julgue encarecimento fantaftico.

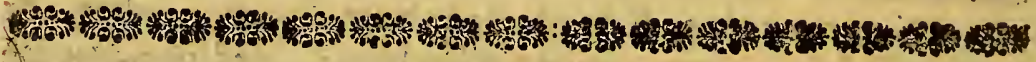

\section{A P I T U L O III.}

Da conduçaö das Boyadas do Certaü do Brafil. prego ordinario do Gado que se ñata, Eo do. que vay para as Fabricas.

Onftaó as Boyadas, que ordinariamente vem para Bahia, de cem, cento \& cincoenta, duzentas, \& tré zentas. Cabeças de Gado: \& déftas quafi cada femana chegaó algumas a Capoâme, Lugar diftante da Cidade oito legoas; zonde tem paito, \& aonde os Marchantes as compraó : \& em alguns tempos do anno ha femanás, em que cada dia chegaó Boyadas. Os que as trazem, faó Brancos, Mulatos, \& Pré: 


\section{¿OOpulencia do Brafil.}

ros; \& tamber Indios, que con efte traballho procuraó ter alguim lucro. Guiaoo fe, indo huńs àdiánte cantando, para ferem defta forte feguidos do Gado ; \& outros vem atraz das Rezes tangendo-as, \& tendo cuidado, que naó fayaố do caminho, \& fe amontem. As fuias jornadas faó de quatro, cinco, \& feis legoas, conforme a cómodidade dọs Paftos, aonde haó de parar. Porém aonde ha falta de agua, fegurem o caminho de quinze, \&r vinte legoas, marchando de dia, \& de noite, com pouco defcanço, até que achem paragem, aonde poffaó parar. Nas paffagens de alguns Rios, hum dos que guiaóa Boyada, pondo húa armaçáo de Boyna cabeça, \& nadando, moftrás Rezes o vao, por onde haó de paffar.

Quemquer que entrega a fua Boyada ao Paffador, para quie a leve das Jacoabinas v. g. atéa Capoâme, que he jorriada de quirize, ou dezafeis até dezafete dias; 1 he dá por paga do feu trabalho hum cruzado por cada cabeça da dita Boyada : \& efte corre com os gaftos dos Tangedores, \& Guias; \& tira da mefrna Boyada a matálotagem da jornada De forte que , fe a Boyada conftar de duzentas Cabeças de Gado; daô-felhe outros tantos cruzados, fe com todas chegar ao lugardeftinado. Porém fe no caminho algumas fugirem; tan tos cruzados fe diminiem, quantas faó as kezes, que fáltaó. Aos Indios, que das Jacoabinas vem para Capoâme y fe daó quatro atè cinco mil reis: \& ao Homem, que com of cu $\mathrm{Ca}$. vallo guia a Boyada, oito mil reis. Sendo as diftancias mayores, crece proporcionadamente a paga de todos. E por ifo do Rio de Saó Francifco acima vindo para Capóâme, alguñs dos que tomaó á fua conta trazer Boyadas alheas ; quereń feis, ou fete toftoens por cada Cabeça; \& mais, fe for mayor a diftancia.

Hüa Rez ordinariamente fe vende na Bahia por quatro atè cinco nuil reis : os Bóys nanfos porfete para oito milireis. Nas Jac abinas vende-fe hüa Rez por dous mil \& quinhen-

tos 


\section{so \\ Culturà,}

tosatè tres mil reis. Porém nos Curraes do Rio de Saó Fran: cifco, os que tem mayor conveniencia de yenderem o Gado para as Minas, ovendem na Porteira do Curral pelo mefmo preço, que fe vende na Cidade. E o que temos dito atè aqui das Boyadas da Bahia, fe deve tambem entender com pouca differença das Boyadas de Pernambuco, \& do Rio de Janeiro.

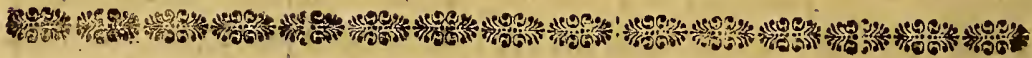

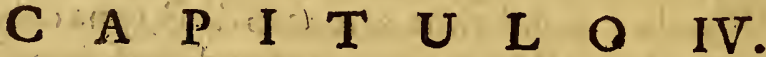

Que cufta bum Couro em cabello, Eo bum Meyo de Sola beneficiado até le pór do Brafil no Alfandega de Lisboa.

V Al cada Couro em cabello De ofalgar, \& fecar

De o carregar ao cortume

De o cortir

Importa tudo dous mil novecentos \& quarenta reis.

$29 U_{40}$

Hum Meyo de Sola val

De o carregar á Praya

I $U_{500}$

De Frete do Navio

Uoro

De defcarga para a Alfańdega

Ur20

Por todos os Direitos

Uaro

Importa tudo mil novecentos \& oitenta reis.

$U_{340 i}$

IU⿴囗十

Os:Meyos de Sola, que ordinariamente vaó cada anno: do Brafil para o Reyro, importaó ofeguinte. 


\section{- Opulencia do Brafil.}

Da Bahia cincoenta mil Meyos de Sola

a $\mathrm{IU} 980$ reis

De Pernambuco quarenta mil a $\mathrm{IU}_{750}$

Do Rio de Janeiro, \& outras Capitanîas

do Sul, vinte mil a IU640 reis ai, 32.800 U000

O que tudo importa duzentos \& hum 201.800 U000 contos, \& oitocentos mil reis: que

99. $000 \mathrm{U} 000$ $70.000 \mathrm{U} 000$ reduzidos a cruzados, faõ quinhentos \& quatro mil ; \& quinhentos

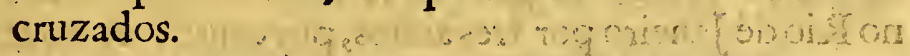

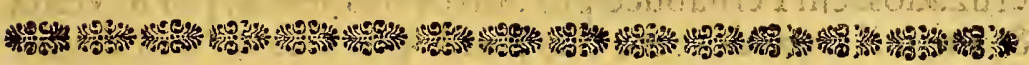

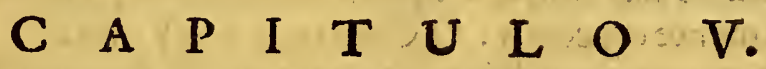

Refumo de tudo o que vay ordinariamente cadd anno do Brafil para Portingal: $G^{\circ}$ do seu valor.

Dor ultima demonftraçaó da Opilencia do Brafil er 1 proveito do Reyno de Portugal, porey aqui agora o Refumo do que nettas quatro Partes tenho apontado; que por junto naó deixarà de caufar mayor admiraçaó, do que póde tercaufado por partes.

- Importa pois todo o Affucar

Importa o Tabaco

Importaó ao menos cem armas $344: 6500000$

Importaó os Meyos de Sola

Importa o Pao Brafil de Pernambuco. $\frac{48.00017000}{3743.292}$ mil fetecentos \& quarenta \& tres contos; 614.400 Uoó 201.800 Uoó $\frac{48.00017000}{3743,292010}$ novecentos \& noventa \& dous mil \& oitocentos reis. Os. quaes 
quaes reduzidosa cruzados, faó nove milhoens, trezentos $\&$ cincoenta \& nove mil, novccentos \& oitenta \& dous cruzados.

Aos quaes fe fe acrecentar o que rende o Contrato das $\mathrm{Ba-}$ leas, que pòr feis annos fe rematou ultimamente na Bahiz porcento \& dez mil cruzados ; \& no Rio de Janeiro por tres annos, por quarenta \& cinco mil cruzados : O Contratoan. nual dos Dizimos Reaes, que na Bahra neftes uitimos annos, fóra as Propinas, chegou perto de duzentos mil cruzados: no Rio de Janeiro por tres annos, pol cento, \& noventa mil cruzados: em Pernábuco por outros tres annos, por noventa \& fete mil cruzados : em Saó Paulo por feffenta mil cruzados; fóra os das outras Capitanîas menores, que em todas notavelniente crecéraó : O Contrato dos Vinbos', que na Bahia fe rematou por feis annos em cento \& noventa \& cinco mil cruzados: em Pernambuco por tres annos em quarenta \& feis mil cruzados; \& no Riode Janeiro por quatro annos por mais de cincoenta mil cruzados : O Contrato do Sal na Bahia arrematado por doze annos, a vinte \& oito mil cruzados cada anno: O Contrato das Aguas Ardentes da Terra, \& de fốra, avaliado por junto ém trintá milcrüzados: O Rendimento da Cafa da Moeda no Rio de Janeiro, que fazendo em dous annos tres milhoens de Moedas de Ouro, deo de lu. croa ElRey, que o compra a doze toltoens a oitava, mais de feiscentos mil cruzados; alem das arrobas dos Quintos, que cadia annolhe vaó: Os Direitos, que fe pagaó nas Alfandegas dos Negros, que vem cada anno de Angola, Saó Thomè, \& Mina em tam grande numero aos Portos da Bahia, Recife, \&Rio de Janeiro, a tres mil \& quinhentos reis por Cabeça: Eos dez por cento das Fazendas no Rio de Janeiro, que importaó hum anno por outro oitenta mil cruzados; bem fe vè a utilidade; que refulta continuamente do Eftado do Brafilá Fazenda Real, aos Portos, \& Reyno de Portu- 


\section{Eo Opulenciado Brafl.}

gal; \& tambem ás Naçuens efrangeiras , que com toda $a$ induftria procuraó aproveita-fe de tudo o que vay defte Eftado.

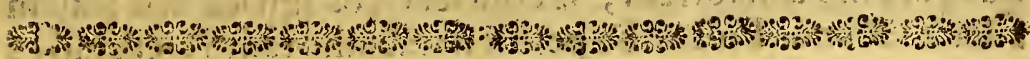

\section{A P I TULO ULTIMO.}

Oudinto be jafto, que fe farorega o Brafil, por Jer de tanta utitidade ao Reyno de Portinal.

1 Elo que temos ditontè agora, naó havert quem pofta 1 duyidar, deferhoje Brafil a melhor, \& a mais util Conquifa, anm para Fazenda Real, como para o bem publico, de quancas ontra conta $o$ Reyno de Portugal, attendendo 10 mutro que cuda anno fac deftes Portos, que fao Miras certas, d abundantenente renofofas. E fe aflim he, quem: durida tambem, que efte tan grande, \& continuo ènolimento nerece juftamente lograr ofavor de Sua Mageftade, \& de todos os feus Mintitos no defpacho das petiçoens, que offerecen, \& na aceitaçaó des meyos, qué para alivio, \& có-

- veniercia dos Moradores, as Cameras defte Eftado humildemente propoem? Se os Senhores de Engenhos, \& os Lá vradores do Affucar, a do Tabaco, faóos que mais promovem hum lucro tam eftimavel; parece, que merecen mais que os outros preferin nofavor, \& achar em todos os Tribunaes aquella prom pra expediçaó, que atalha as dilaçoens dios requerimentos, \& o enfado, \& os gaftos de prolongadas demandas. Se crece tam copiofo o numero dos Moradores, na. turaes de Portugal, que cada vez naais povoaó as partes, que antes eraó defertas, ficando muito diftantes das Igrejas; he jufto; que eftas fe multipliquem, para que todos tenhiaó $\mathrm{N}$ mais 
194 Cultura,

mais perto oneceffario remedio de fuas Almas. Pagando-fe tain pontualmenté á boldadefca, queallifte nas Praças, \& nas Fortalezas Maritimas ; naó poderiaó deixar de fentir os que para iffo concorrem, fe com ferviços iguaes nao fortem ádiantadós nós Póltos. Se pelo feu traballio tanto creceraó $r$ s Dizimos; que fe offerecem a Deos; pede a razaó, que os feus Filhos idonecs naó fejao pof poftes nos Concurfos, \& provimentos das Igrejas vacantes do Eftado. E fendo cómunmente tam efinoleres com os Polsres, \& tam liberacs para o culto divino, imerecen ter a Deos propiciona Terra, \& Remunerador eterio no Ceo.

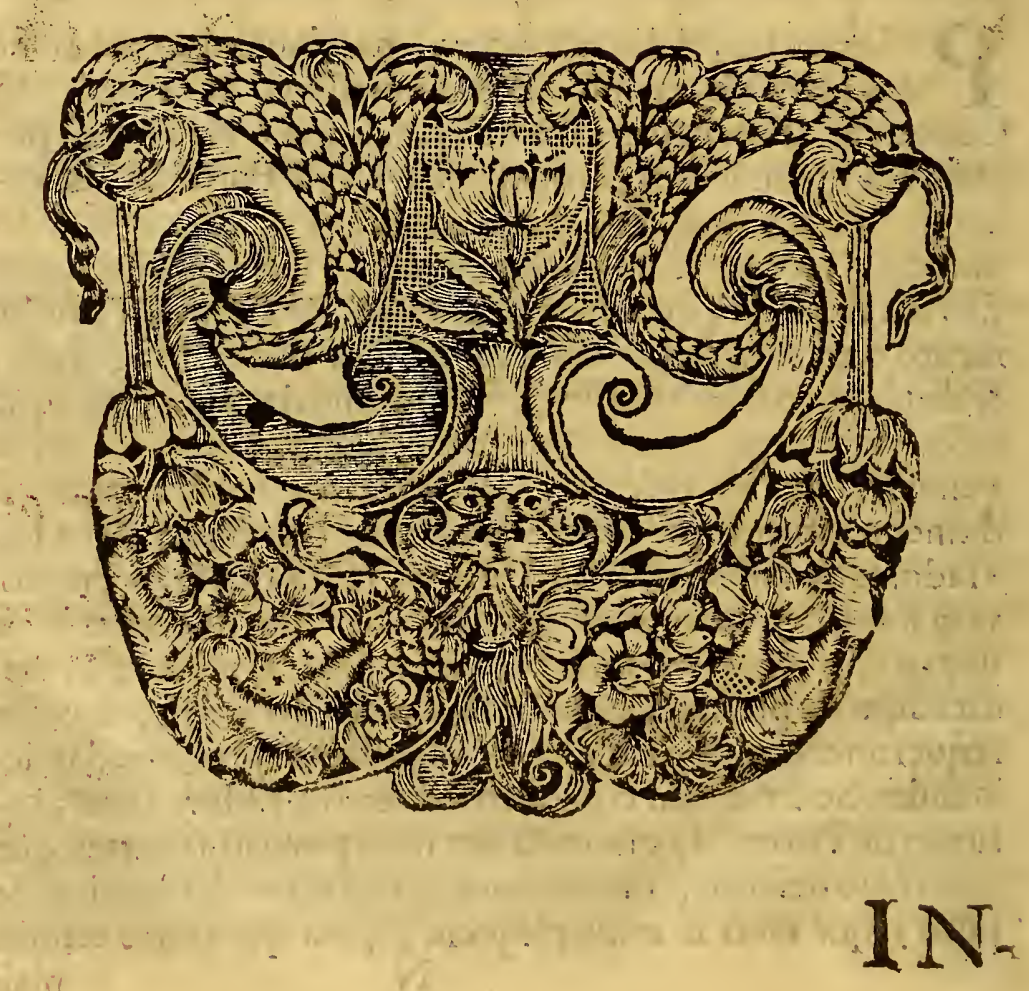




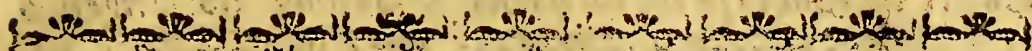

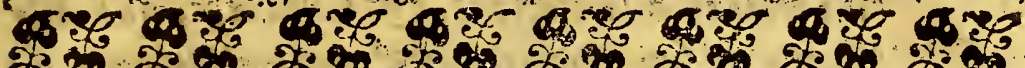

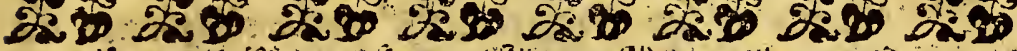
rof 3 -

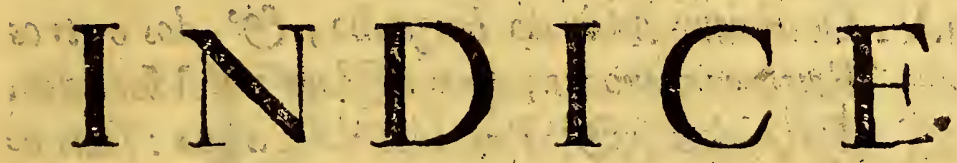

\section{PRIMEIRA PAR TE.}

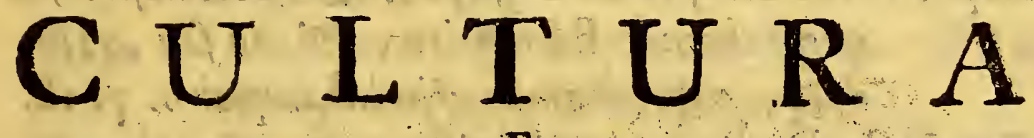

E

OPULENCIA DOBRASIL Na Lavia do Aflucar.

\section{I V R O I.}

- Cap. I. O Cabedal, que ba de ter o Sentior dé 10 Uusn Engenbo Real. pag.1. Cap.II. Como fe ba de baver o Jéribor dlo Engenho na compra, Ẽ confervaçe dus Terras, EN nos Arrendainentos dellas. p.5.

Cap.IH. Comio fé bade waver o Jenulor do Engenho com os Lauradores; Eontros virizbos; Eo eftes com o Senbor.p. 7 .

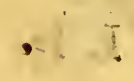
$\mathrm{N}_{2}$
Cap.IV. 


\section{I06 Indice.}

Cap.IV, Coms le ba de baver o Senbor do Engenbo na eleigaö das Peffoas, EO Officiales, quie ads mittir as fen fervigo: Es primeiraniente dia. eleiçaó do Capellió p.ro.

Cap.V. Do Feiter Már do Engrenbo, Eo dos outros Feitoresmenores, que affiftem na Moenda, Fazendas, E- Partidos da Canna: fuas o=

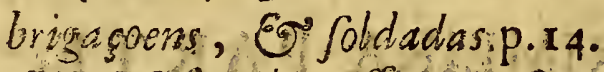

Cap.VI. Do Mefire do Aflucar, Eo Sotomefre, a quem cham dande, a que cham do Ajudabanqueiro. p. 18.

Cap.VII. Do Purgador dö Alfucar. p.zo.

Cap.VIII, Do Caixeiro do Engenbo. p.2I.

Cap. IX. Coma se ba de haver o Senhor do Engenho com feus Efcravos. p.22.

Cap. X. Como fe ba de baver o Senbor do Engenbo no governo dia fur Familia, Eo nos gastos ordi. narios de cafa. p.29.

Cap.XI. Como fo ba de baver o Senbor do Engentio no resebimento dos Hofpedes, afim Religiofos,

D.: como Seculares. P. 31 .

Cap. XII. Como fe ba de baver o Senbor do Engenbo com os e Mercadores, Es outros fens Correspondientes na Praģa: Eo de alguns wiodos do vender, Eo comprar o Afficar, conforme 0 aftulo do Brafal. p.33. 


\section{Primeira Parte.}

\section{I V R O II.}

Cap. I. D A escolba da. Terra, para plantar. Cannas de Alfucar, Eo para os mantimentos neceßarios, $\Xi$ provimento do Engenbo.p. 36.

Cap. II. Da planta, Es limpas das Cannas : E da diverfidade, que ba nellas.p. 38 . .

Cap.III. Dos Inimigos da Canna, em quanto eftà no Cannaveal. p.41.

Cap.IV. Do córte da Canna, E Jua conduçă pa= ra o Engenho. p. 42.

Cap.V.Do Engento, ou Cafa de moer a Can= na : E' como se move d Moenda con agua. P. 46.

- Cap.VI. Do modo de moer as Cannas : Es de quans tas Peffoas necefita a onoenda.p. 53.

Cap.VII. Das Madeiras, de que fe faz a Moen da, Es todo o mais madeiramento do Engenbo, Canoas, Er Barcos: Eั: do que fe cofumia dar aos Carpinteiros, Eo outros /emes Ihantes Officiaes. p.56.

Cap.VIII. Da Caja das Fornalbas, feu aparelibo, $\mathrm{N}_{3}$ 
198

\section{Indice.}

Es Lenba, que ba mifter, Eo da Cinza, छ॰ fua Decoada.p.59.

Cap.IX. Das Caldeiras, Ẽ Cobres, Sen aparelho, - Officias, $\mathcal{G}^{\circ}$ Gente, que nellas hamifter : E० Inftrumentos, de que usăo. p.63.

Cap.X. Domodo de alimpar, Ẽ purificar o Caldo da Canna nas Caldeiras, Es no Paról de coar. atè pafjar para as Tachas. p. 67.

Cap.XI.Do modo de cozer, Eo bater o Melado nas Tachas.p.69.

Cap.XII. Das Temperas do Melado: Eo fua jufle repartigau pelas Formas. p.72.

\section{IVR O III.}

Cap. I. As Formas do Aßucar, EO fua pasfagem do Tendal para a Casa de pur= gis $a \dot{r}$. P. 75 .

Cap. II. Da Cafa de purgar o Affucar nas Formas. p. $77^{\circ}$

Cap.III. Das pefjoas, q se occupaô em purgar, masca- var, Jecar, E encaixar o ßsगucar: Eo dos Inftruinentos, $\bar{q}$ para iffo fao necelfairios.p. 79 . Cap.I V. Do Barro, que se bora nas Formas do - $\iint \mathrm{cu}$ car: qualdeve fer, Ẽ como je ba de amalfar: Ẽ se. 


\section{Primeira Parte.}

\&o se be bem, ter no Engenbo Olaria. p. $8 \mathrm{r}$. Cap. V. Do modo de purgar o Alfucar nas Formas: Go de todo o beneficio, que je lhe faz na $C a$ sa de Purgar, até Se tirar.p 83.

Cap.VI. Do modo de tirar, mascavar, E๑ secar ao A S.rear.p 86.

Cap.VII. Do Pezo, Repartiçă, Eऽ Encaixamento do Aßucar. p.89.

Cap.VIII. De varias caftas de Affucar, que feparadanente Se encaixaö: Marcas das Gaixas, Eq fua conducçaö an Trapiche. p.9r.

Cap. IX. Dos Pregos antigos, 60 modernos do $A f=$ fucar. P.94.

Cap. X. Do numero das Caixas de $A \beta u c a r$, que $\int e$ fazem cada anino ordinariamente no Brafil. P.96.

Cap.XI. Q) wa cufte bria Caixe de Aflucar de trinta E. cinco arrobas, pofta na Alfandega de Lisboa, Eo jà de pachada: Eo do valor de todo - AfJucar, que cada anno le faz no Brafil. p. 97.

Cap. XII. Do que padece o Aljucar delde o seunaci. mento na Canna, ate Sabir do Brafil.p. 102. 


\section{Indice.}

* *...

\section{SEGUNDA PARTE.}

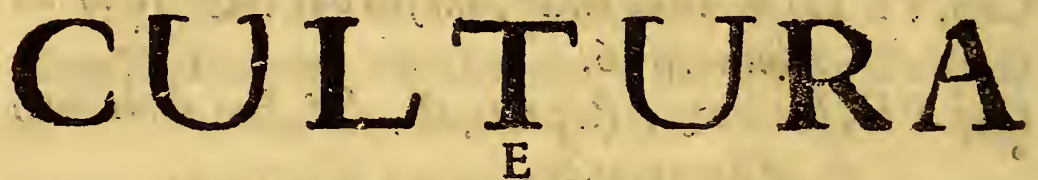

OPVLENCIA DO B R A IL Na Lavra do Tabaco.

Cap.I.

OMO fe comegou a tratar no Brafll L. da Plantado Tabaco: Es a que eglimaģaó tem chegado p.10\%.

Cap.II. Em que confifte a Lavra do Tabaco: 85 de como fe femea, planta, Es alimpa : Es em que tempo Je ba de plantar.p. rog.

Cap.III. Como fe tiraó, Eo curaó as folhas do $T a$ baco: Ẽ como dellas fe fazem, Eూ beneficia as cordas. P.III.

Cap.IV. Cormo fe cura o Tabaco depois de torcido em corda.p. II2.

Cap. V. Como Se enrola, Eo encoura o Tabaco: Eூ que Peßoas se occupaō em toda a fabrica delle, defce a fua planta atè fe enrolar. p.1 13.

Cap. 


\section{Segunda Parte.}

Cap.VI. Da fegunda, Es terceira folba do Tabaco: Eo de diver ras qualidades.delle, para se marcar, cachimbar, E๐ pizar.p.II5.

Cap.VII. Como Je piza o Tabaco : do Granido, Eூ em pó; Ẽ como se lhe dá o cheiro. p. I 6;

Cap.VIII.Do ufo moderado do Tabaco para a saude: E da demafia nociva à mefima faude, de

3 qualquer modo quie se use delle. p.I18.

Cap.IX. Do modo com que se despactia o Tabaco no Alfandega da Babia.p.I20.

Cap.X. Que custa bum Bolo de Tabaco de oito arro= bas, pofto da Babia na Alfandega de Lisboa, E ja despacbado, Es corrente para Sabir della. p. I22.

Cap.XI.Da effimaģă do Tabaco do Brafil na Euro. pa, $\mathcal{F}^{\circ}$ nas mais Partes do Mundo: $\mathcal{F}^{\circ}$ dos grandes emolamentos, que delle tira a $F$ azenda Real.p.i 24.

- Cap.XII. Das penas dos que levaö Tabaco naŏ despachado nas. Alfandegas: Eo das induftrias, de que je usa para fe levar de contrabando. p.126. 


\section{2}

\section{Indice.}

\section{TERCEIRA PARTE.}

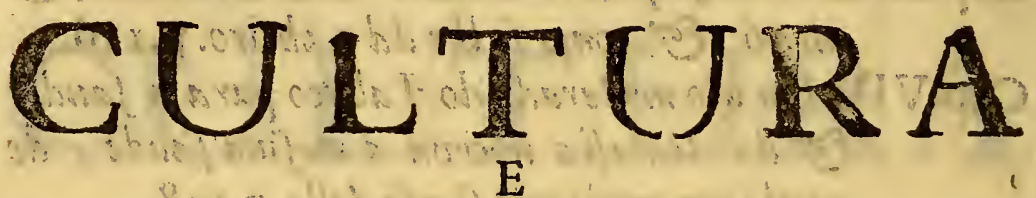

\section{OPVLENCIA DO BRASIL}

Pelas Minas do Ouro.

Cap. I. As Minas do Ouro, que Se defcobriraönoBrafil.p.izg

Cap. II. Das Minas do Oura que ibamaö Geraes: Eo dos descobridores dellas. p. $13 \mathrm{I}$.

Cap. III. De outras Minas de Ouro no Rio das $V e=$ lhas, Ẽ no Caetê.p. 133.

Cap.IV. Do rendimento dos Ribeiros: E- de diverfas 1 qualidades de Owro, que delles Se tirat p. $\mathbf{3 4}$. Cap. V. Das Peffoas, que añiaö nas Minas, $\mathcal{E}^{\circ} \mathrm{ti}$ rāo Ouro dos Ribeiros. p. 136 .

Cap. VI. Das Datas, ou Reparicigoenis das Minas. P.I $3^{8}$.

Cap.VII.Da abundancia de Mantimentos, Eo de to= dooufual, que boje ba nas Minas: $\mathcal{E}^{\circ}$ do pouco caso que ee faz dos pregos extraordina= riamente altos.p.I39. Cap. . 


\section{Segunda Parte.}

Cap. VIII. De diver Jos preços do Ouro vendido no Brafil: Go do qumporta o que cada anno or's dinariamente fe tira das Minas.p. 143.

Cap.IX. Da obrigaça de pagar a El=Rey No fJo Se. nhor a quinta parte do Ouro, que fe tiradas Minas do Brafil. piI 46.

Cap.X. Roteirodo Caminbo da Villa de S.Paulo para as Minas Geraes, Ë para o Rio das $V_{e=}$ thas pis 59.

Csp.XI.Roreiro do Caminho velbo da Cidade do Rio de Faneiro para as Minas dos Caraguâs, Go do Rio das Velbas p. 163.

Cap. XII. Roteiro do Caminbo novo da Cidade do Rio de faneiro para as Minas. p.164.

Cap XIII.Roteiro do Cáminbo da Cidade da Babia us toara as Minas do Rio das Velbas.p I 65.

Cap.XIV.Modo de tirar.o Ouro das Minas do Bra= fil, So dos Ribeiros dellas, obfervado de que nellas a/fitio cô o Governador. Artìr de J'à. p. 168.

Cap. XV. Noticias, para fe conbecerë as Minas de Prata. p. 173.

Cap.XVI. Modo de conbecer a Prata, $\sigma^{\circ}$ de benefi= ciar os $M$ Letaes. p. 176.

Cap.XVII. Dos danos, q tem causado ao Brafil a có biga, depois do des cobrimento do Ouro nas Mi. nas.p. 179.

QVAR. 
$204^{\prime}$

Indice.

Or.

\section{QVARTA PARTE.}

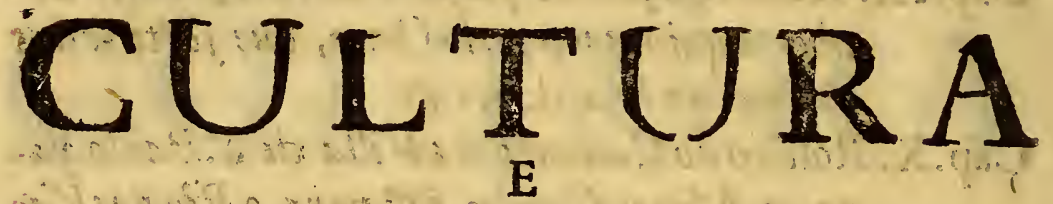

OPVLENCIA DO B R A S L Pelà abundancia do Gado, \& Cou-

rama, \& outros Contratos

Reaes, q́ fe remataó nefta

Conquifta.

Cap. I. A grande exten $\int a \tilde{o}$ de Terras para Paftos, cheas de Gado, que ha no Bra= fil. p.183.

Cap. II. Das Boyadas, que ordinariamente se tiraö cada anno dos Curraes para as Cidades, Villas, E' Reconcivos do Brafil, aflimparao Açongue, como para ofornecimen to das Fabricas. p. 187.

Cap. III. Da conduçaö das Boyadas do Certaö do Brafal : prego ordinariodo Gado, que fe mata, Eo do que vay para as Fabricas. p.1 88.

Cap." 


\section{Quarta Parte.}

Cap IV.Que cufta bum Couro em cabello, bum Meyo de Sola beneficiado até Se pôr do Brafil ina Alfandega de Lisboa. p.igo.

Cap.V. Refumo de tudo o que vay ordinariamente cas da anno do Brafel para Portugal : E do deu valor.p.igr.

Cap.ultimo. Quanto be jufo, que fe farvoreca o BraJil, por fer de tanta utilidade ao Reyino de Portusal. p.1g3.

\section{FINIS, LAUS DEO.}




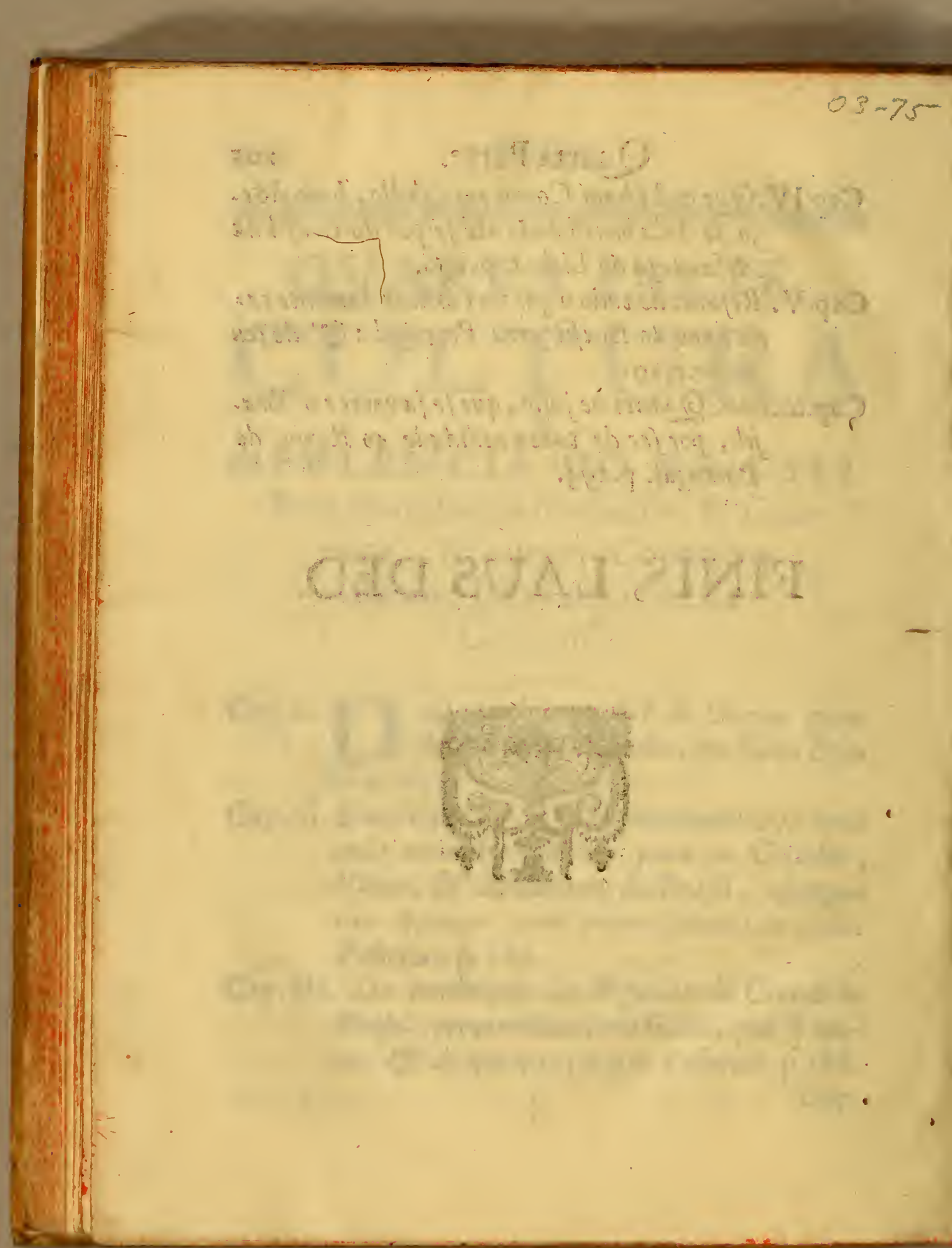


3 


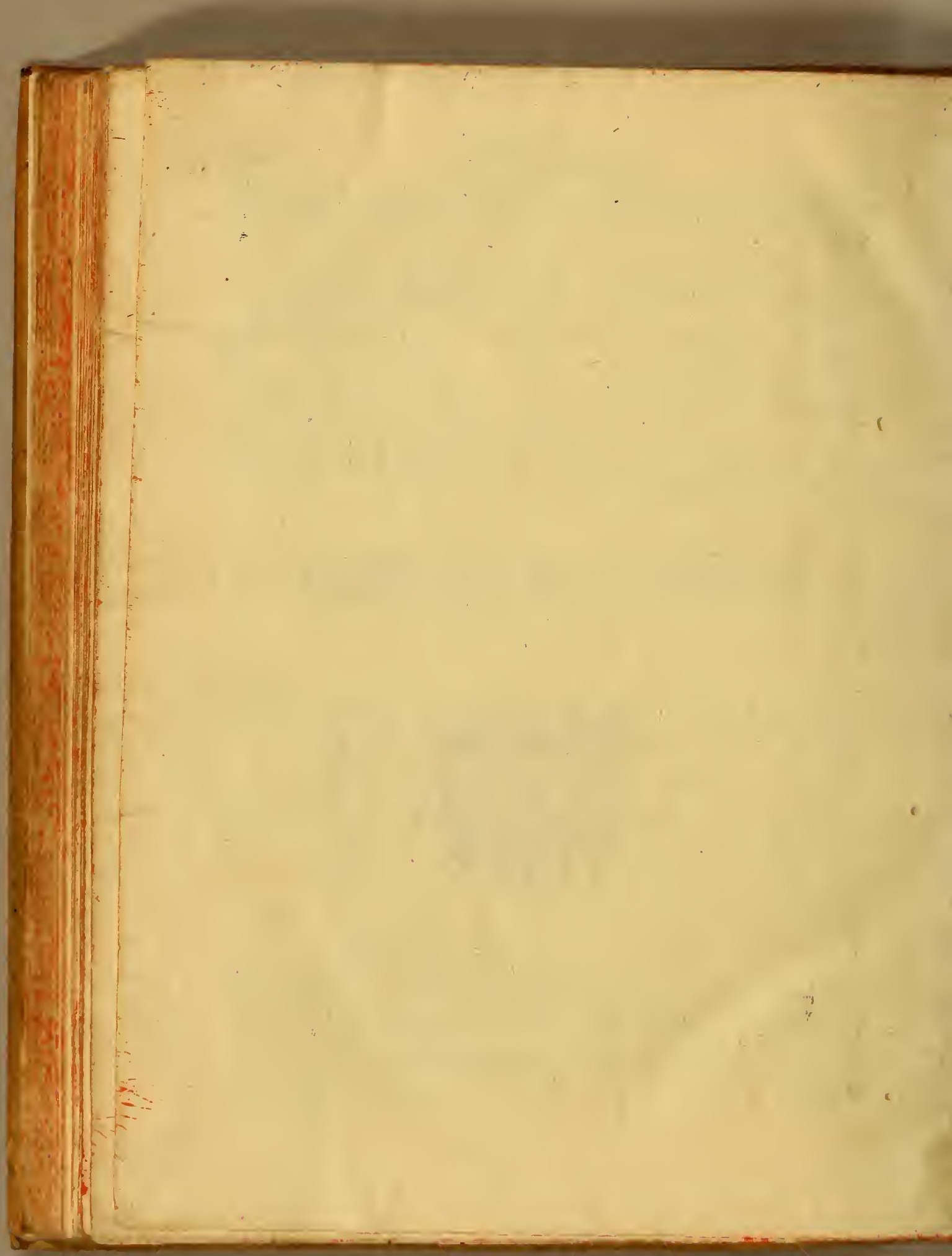





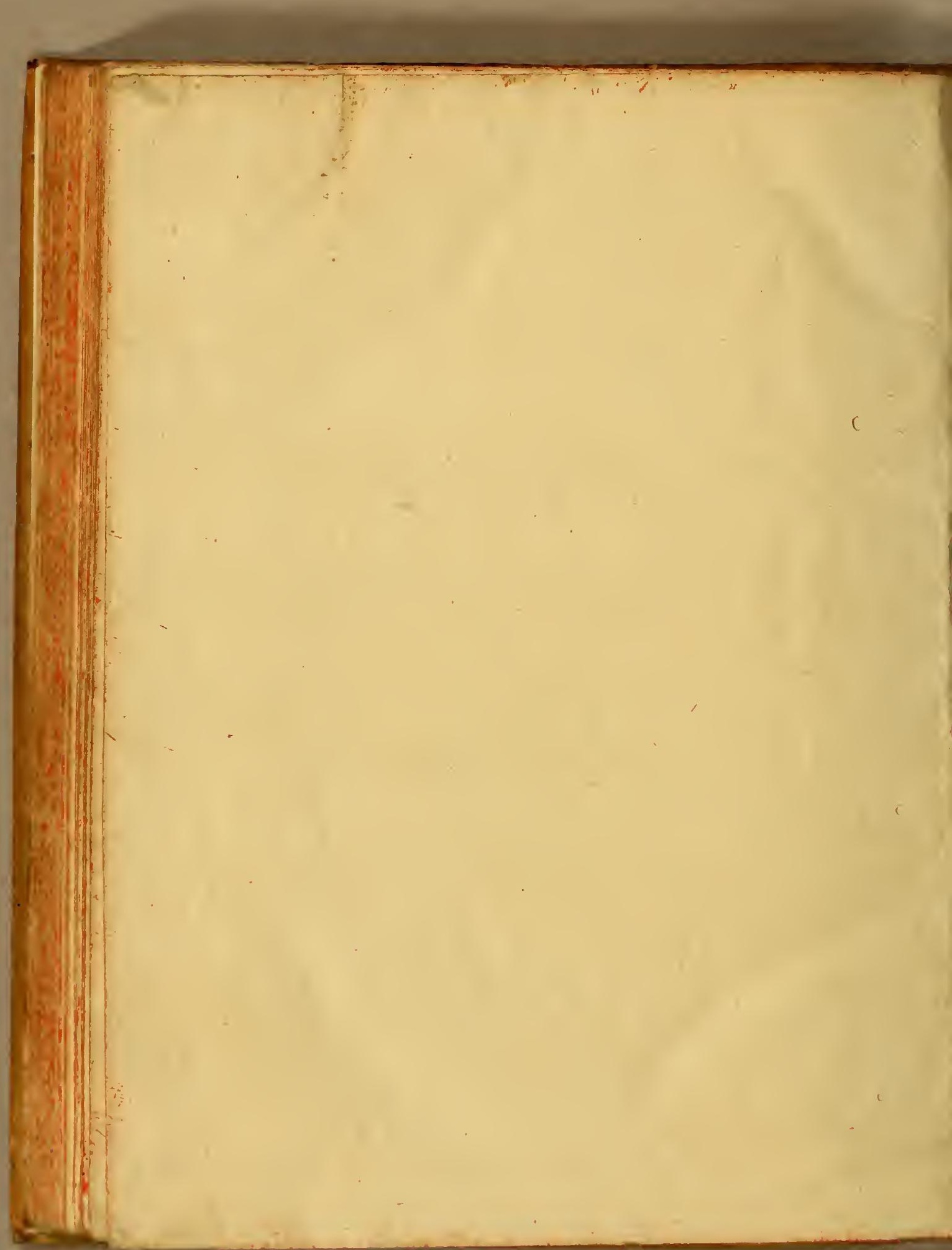





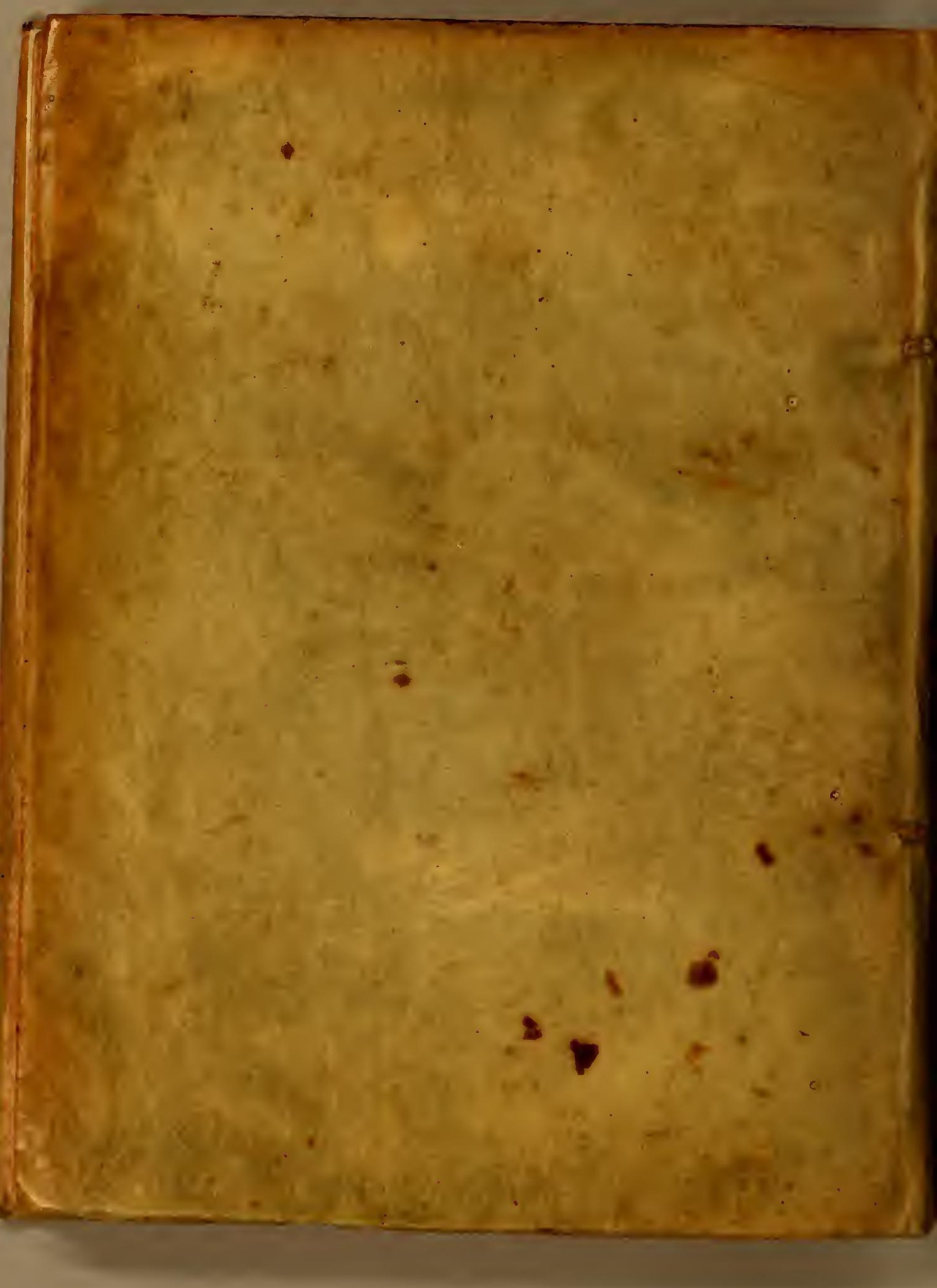

